UNIVERSIDADE DE SÃO PAULO

FACULDADE DE SAÚDE PÚBLICA

DEPARTAMENTO DE NUTRIÇÃO

TESE DE DOUTORADO

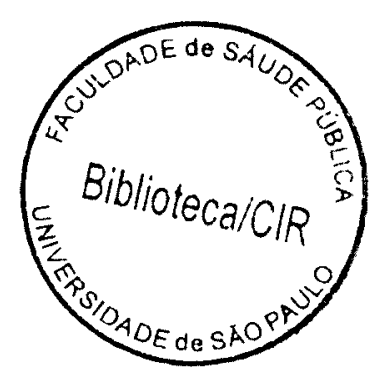

\title{
CONTEÚDO INFORMATIVO DAS EMBALAGENS DE ALIMENTOS: \\ UM ESTUDO EXPLORATÓRIO INTERNACIONAL COMPARADO, SOB A ÓTICA BRASILEIRA E NORTE-AMERICANA DOS AGENTES DE PRODUÇÃO E CONSUMO
}

VIRGÍNIA MARIA FERRAZ DE CASTRO

Tese de Doutorado apresentada ao Departamento de Nutrição da Faculdade de Saúde Pública da Universidade de São Paulo, para obtenção do título de Doutor em Saúde Pública.

ORIENTADOR: PROF. DR. RUBENS DA COSTA SANTOS

SÃo PAULO

2000 
Autorizo, exclusivamente para fins acadêmicos e cientificos, a reproduçăo total ou parcial desta dissertaçăo, por processos fotocopiadores.

Assinatura:

Data

$$
40727 / 2001 \text { (doc) }
$$




\section{DEDICATÓRIA}

Aos meus pais Ipê (in memoriam) e Dolores, cuja presença marcante diferenciou minha vida. 


\section{AGRADECIMENTOS}

Ao Prof. Dr. Rubens da Costa Santos, meu dedicado orientador, pelo grande estímulo e enriquecimento que proporcionou ao meu trabalho, a manifestação do meu profundo reconhecimento.

Ao meu amigo Sílvio Popadiuk que muito me apoiou com seus conhecimentos e suas experiências.

Aos amigos Sevgin Eroglu, Matthew Lee Jr., Greyze Vieira e Cristina Bugara pelas inúmeras contribuições e pelo carinho prestados durante minha permanência nos EUA, para a realização da bolsa sanduiche.

Ao meu amigo Alessandro Tadei pela dedicação e, sobretudo, pelo apoio na definição da arte gráfica do trabalho.

Aos consumidores brasileiros e norte-americanos, pela colaboração que viabilizou a consecução deste trabalho.

À empresa Kellogg's (do Brasil e dos EUA), especialmente, aos profissionais entrevistados, pela atenção concedida e pelas informações prestadas.

A todos os professores do Programa de Pós Graduação, pela solidez nos ensinamentos.

A CAPES e ao CNPq, pelas concessões, respectivamente, de uma bolsa sanduíche e de uma bolsa de doutorado, que viabilizaram a concretização deste trabalho.

À bibliotecária Ângela Maria Belloni Cuenca, pelo seu trabalho de revisão bibliográfica.

A todos os amigos que estiveram presentes ao longo desta jornada. 
deCastro, VMF Conteúdo informativo das embalagens de alimentos: um estudo exploratório internacional comparado, sob a ótica brasileira e norte-americana dos agentes de produção e consumo. São Paulo, 2000. [Tese de Doutorado - Faculdade de Saúde Pública da USP].

\section{RESUMO}

O objetivo do presente estudo compreende a análise das estratégias adotadas pelo consumidor por ocasião da seleção, aquisição e uso dos alimentos, no que tange o conteúdo informativo das embalagens de alimentos.

Realizou-se um Estudo Exploratório Internacional Comparado (EEIC), segundo a ótica brasileira e norte-americana dos agentes de produção e consumo. O enfoque da pesquisa voltou-se para os aspectos relacionados à identificação da estrutura ordenada de preferência pelos atributos de uma dada categoria de produto alimentício. A abordagem sistêmica contribuiu para ressaltar que a comunicação dos atributos do produto é feita em função do seu público consumidor.

Concluí-se que a adoção de medidas que levem em consideração a relevância dos atributos do produto, bem como as peculiaridades de cada cultura irão subsidiar a tomada de decisão dos profissionais envolvidos no processo de desenvolvimento da embalagem, no sentido de buscar o aprimoramento do conjunto de informações voltado para a promoção e venda dos gêneros alimentícios, segundo as exigências do mercado de consumo. A busca constante pela atualização, modernização e padronização das informações contidas nas embalagens de alimentos evitará que o consumidor desenvolva conceitos errôneos e/ou empregue inadequadamente um determinado produto alimentício em sua dieta alimentar diária. 
deCastro, VMF Informative content of food packaging: an exploratory international comparative study, from the point of view of Brazilian and American production and consumption agents. São Paulo, 2000. [Thesis - School of Public Health. University of São Paulo].

\begin{abstract}
This study examined the effect of the information content on the consumer's strategies when selecting, acquiring and using foods.

Based on the bibliography about these issues, an exploratory international comparative study has been carried out, from the point of view of Brazilian and American production and consumption agents. The study attempted to obtain new information on the preference structure of consumer through a list of attributes of a food item which is commercialized in both countries studied. The proposed systemic approach has demonstrated to be helpful for recognition that the communication of the attributes of a food item is done based on the behavior of the consumer in relation to the use that he or she makes of the information contained on food packaging.
\end{abstract}

Briefly stated the adoption of measures which take in consideration the ranking of the attributes of a food item, as well the peculiar characteristics of each culture might contribute to facilitate the made decision of professionals charged in the process for package development to improve the presentation of a set of information, for the publicity and sales of foodstuffs according to the demands of the market. The search for a set of information up-to-date, modern and standardized might help the consumers to use property a foodstuff in their daily feed diet. 
1. INTRODUÇÃO

1.1. Conteúdo Informativo das Embalagens de Alimentos na Tomada de Decisão do Consumidor

1.2. Abordagem Sistêmica da Embalagem no Processo da Comunicação

1.2.1. Relação entre o consumo do alimento e seus benefícios na saúde pública

1.3. Contribuições do Estudo

1.4. Organização do Trabalho

1.5. Referências

2. REVISÃO DA LITERATURA SELECIONADA SOBRE O ASSUNTO

2.1. Caracterização do Setor de Embalagem

2.1.1. A embalagem na economia de mercado $\mathrm{e}$ a dinâmica do setor de alimentos

2.1.2. Abordagens conceituais

2.2. Embalagem de Alimentos e o Comportamento do Consumidor

2.2.1. Considerações gerais

2.2.2. Aspectos conceituais e o comportamento do consumidor

2.2.2.1. Considerações gerais

2.2.2.2. A teoria do comportamento do consumidor

2.2.2.3. O aspecto "cross-cultural"

2.2.2.4. A estrutura de preferência de atributos e o conteúdo informativo das embalagens de alimentos

2.2.3. Estudos sobre o comportamento de compra do consumidor norte-americano

2.2.4. Estudos sobre as tendências do comportamento de compra do consumidor brasileiro

2.3. Embalagem de Alimentos e o Comportamento do Consumidor: Relação entre Qualidade e Lucro

2.3.1. Consideraçð̃es gerais

2.3.2. Abordagem conceitual de um programa de avaliação de investimento em qualidade

2.3.3. Um programa de avaliação de investimento em qualidade e a embalagem de alimentos

2.3.3.1. Programa de avaliação de investimento em qualidade

2.3.3.2. A embalagem de alimentos e um programa de avaliação de investimento em qualidade

2.4. Aspectos Sumarizadores

01

03

04

06

07

07

3. METODOLOGIA

3.1. Considerações Gerais

3.2. Propósito e Foco do Estudo

3.3. Premissas do Estudo

3.4. Método

3.5. Procedimento

3.5.1. O mercado de cereais

3.5.2. Caracterização das empresas

3.5.3. Estudo Exploratório Internacional Comparado - EEIC

3.5.3.1. Evolução histórica e aplicação da pesquisa internacional comparada 
4. RESULTADOS E ANÁLISES

4.1. Descrição da Amostra

4.2. Análise do Produto 75

4.2.1. Entendimento dos respondentes acerca do conceito "alimento" 75

4.2.2. Entendimento dos respondentes acerca do conceito "cereal matinal" 76

4.2.3. Entendimento dos respondentes acerca do conceito "cereal matinal" para as marcas compradas e consumidas

4.2.4. Entendimento dos respondentes acerca do conceito "principal função do cereal matinal"

4.2.5. Aspectos positivos e negativos no cereal matinal 83

4.2.6. Perfil dos compradores e consumidores de cereais matinais 85

4.2.7. Informações impressas nas embalagens de cereais matinais lembradas pelos repondentes para as marcas mencionadas

4.2.8. Endimento dos respondentes acerca do conceito "papel da embalagem de cereal matinal"

4.2.9. Facilidade/ dificuldade em encontrar as informações impressas nas embalagens de cereais matinais"

4.2.10. Adequação/ inadequação da informação nutricional impressa nas embalagens de cereais matinais"

4.2.11. Entendimento dos respondentes acerca do conceito "embalagem ideal" 99

4.2.12. Papel do serviço de atendimento ao consumidor - sac - das empresas produtoras de cereais matinais"

4.2.13. Relevância dos atributos impressos nas embalagens de cereais matinais 103

$\begin{array}{ll}\text { 4.2.14. Grau de aderência dos atributos ao modelo sistêmico } & 104\end{array}$

$\begin{array}{ll}\text { 4.2.15. Classificação dos atributos } & 115\end{array}$

4.3. Estudo com Empresa Norte-Americana e Brasileira Produtora de Cereais Matinais $\quad 125$

$\begin{array}{ll}\text { 4.3.1. Empresa norte-americana produtora de cereais matinais } & 126\end{array}$

4.3.1.1. Processo de desenvolvimento da embalagem 126

4.3.1.2. Aspectos conceituais: entendimento do profissional norte-americano
entrevistado

4.3.2. Empresa brasileira produtora de cereais matinais $\quad 144$

4.3.2.1. Processo de desenvolvimento da embalagem $\quad 144$

4.3.2.2. Entendimento do profissional brasileiro entrevistado 149

5. CONCLUSÕES, IMPLICAÇÕES, LIMITAÇÕES E DIRECIONAMENTOS PARA ESTUDOS FUTUROS

$\begin{array}{lc}\text { 5.1. Similaridades e Diferenças Encontradas } & 158\end{array}$

$\begin{array}{ll}\text { 5.1.1. Similaridades } & 158\end{array}$

$\begin{array}{ll}\text { 5.1.2. Diferenças } & 160\end{array}$

$\begin{array}{ll}\text { 5.2. Adequação do Modelo Sistêmico } & 161\end{array}$

5.2.1. Abordagem sistêmica e a visão dos agentes de produção e consumo 162

5.3. Considerações Gerais 166

5.4. Implicaç̋̃es, Limitações e Direcionamentos para Estudos Futuros 167

$\begin{array}{ll}\text { 5.4.1. Implicações } & 167\end{array}$

5.4.2. Limitações e direcionamentos para estudos futuros 168 
LISTA DE APÊNDICES

Apêndice 1 Cereais ofertados no Brasil e nos EUA

Apêndice 2 Kellogg Company - portifólio de produtos

Apêndice 3 Filtro e roteiro de entrevista utilizados na realização da pesquisa

Apêndice 4 Cartas de apresentação

Apêndice 5 Embalagens consideradas no estudo

\section{LISTA DE FIGURAS}

Figura 2.2.2.3 Os efeitos sócio-econômicos e culturais sobre o desempenho das estratégias

globais da imagem da marca

Figura 2.2.2.4a Estágios do processo de compra

Figura 2.2.2.4b

Processo de tomada de decisão do consumidor

Figura 2.2.2.4c

Determinantes para o reconhecimento da necessidade

Figura 2.2.2.4c'

O processo de reconhecimento da necessidade

Figura 2.2.2.4d

Processo de busca interna de informação

Figura 2.2.2.4d'

Busca de informação no modelo de tomada de decisão

Figura 2.2.2.4e

A avaliação da informação no modelo de tomada de decisão

A compra no modelo de tomada de decisão

\section{LISTA DE GRÁFICOS}

Gráfico 4.2.14a Distribuição do grau de aderência dos atributos em relação ao modelo sistêmico (valores em porcentagem)

Gráfico 4.2.14b Distribuição do grau de aderência dos atributos adicionados pelos entrevistados (valores em porcentagem)

Gráfico 4.2.15a Distribuição da classificação dos atributos, segundo os brasileiros (valores em porcentagem)

Gráfico 4.2.15b Distribuição da classificação dos atributos, segundo os norte-americanos (valores em porcentagem)

Gráfico 4.2.15c Distribuição da classificação dos atributos adicionados, segundo os entrevistados (valores em porcentagem)

LISTA DE QUADROS

Quadro 2.2.2.4 A hierarquia de necessidade de Maslow 
LISTA DE TABELAS

Tabela la Faixa Etária 75

Tabela lb Renda Individual Anual 75

Tabela 4.2.1 Entendimento do conceito "alimento" (valores em porcentagem)

Tabela 4.2.2 Entendimento do conceito "cereal matinal" (valores em porcentagem) 77

Tabela 4.2.3 Quantidade de respondentes que declararam o conceito "cereais matinais para as marcas compradas e consumidas (valores em porcentagem) $\quad 80$

Tabela 4.2.4 Entendimento do conceito "principal função do cereal matinal" (valores em porcentagem)

Tabela 4.2.5 Quantidade de respondentes que declararam aspectos positivos e negativos no cereal matinal (valores em porcentagem)

Tabela 4.2.6 Quantidade de respondentes que declararam aspectos do perfil dos compradores e consumidores de cereais matinais (valores em porcentagem)

Tabela 4.2.7 Quantidade de respondentes que declararam ter se lembrado das informações impressas nas embalagens de cereais matinais que costuma consumir (valores em porcentagem)

Tabela 4.2.8 Entendimento do conceito "papel da embalagem de cereal matinal" (valores em porcentagem)

Tabela 4.2.9 Quantidade de respondentes que declararam aspectos relativos à facilidade/ dificuldade em encontrar as informações impressas nas embalagens de cereais matinais (valores em porcentagem)

Tabela 4.2.10 Quantidade de respondentes que declararam aspectos adequados/inadequados da informação nutricional impressa nas embalagens de cereais matinais (valores em porcentagem)

Tabela 4.2.11 Entendimento do conceito "embalagem ideal" (valores em porcentagem) 99

Tabela 4.2.12 Quantidade de respondentes que declararam o papel do "Serviço de Atendimento ao Consumidor - SAC" (valores em porcentagem) 103

Tabela 4.2.13 Citações coincidentes 


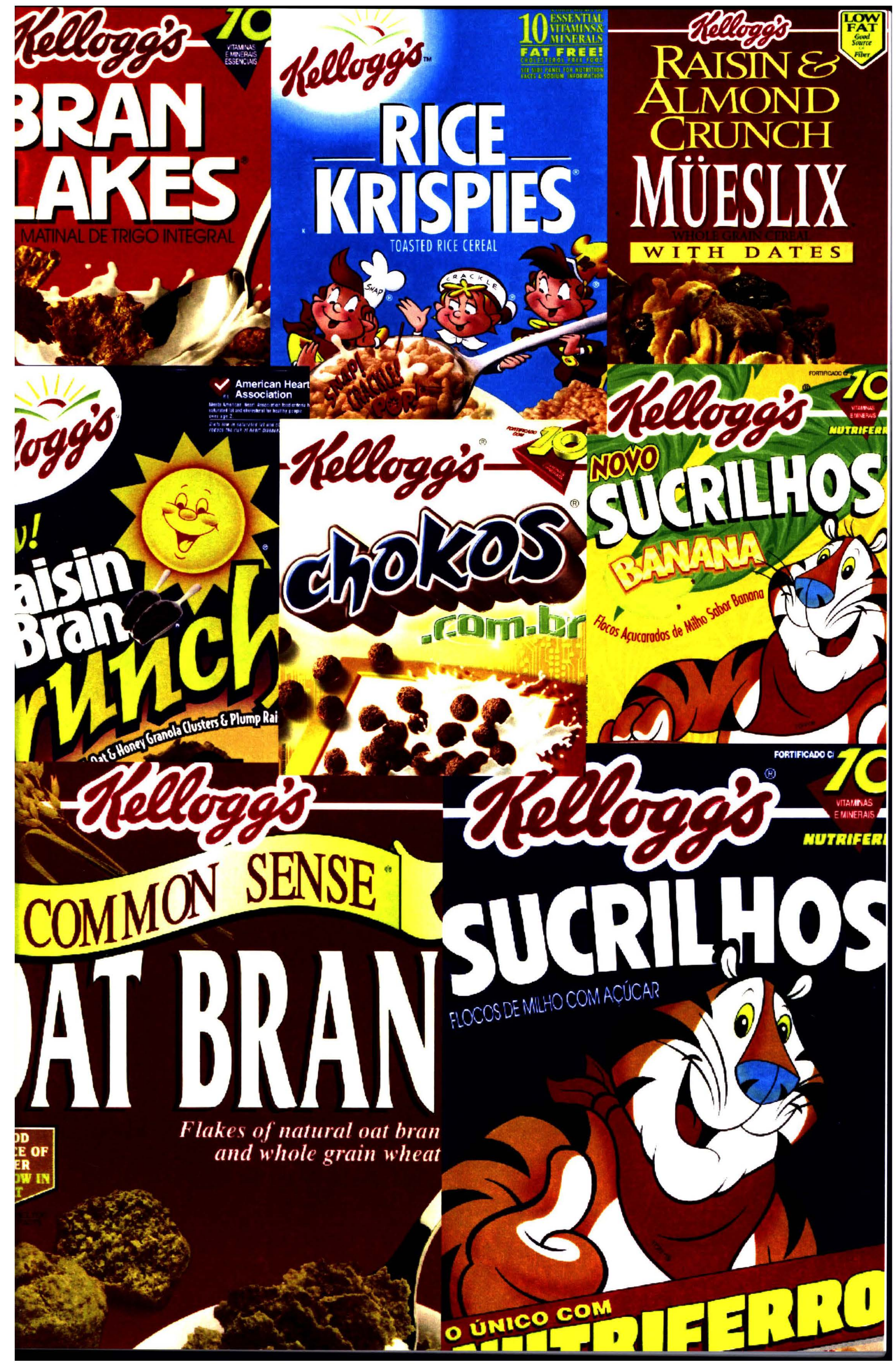




\section{CAPÍTULO 1 INTRODUÇÃO}




\section{INTRODUÇÃO}

\subsection{Conteúdo Informativo das Embalagens de Alimentos na Tomada de Decisão do Consumidor}

O desenvolvimento do presente estudo é um pioneirismo no Brasil. A pesquisa realizada abordou o conteúdo informativo das embalagens de alimentos, que poderão propiciar a identificação de nichos de mercado, bem como contribuir para a segmentação de mercado.

A embalagem, além de ser um veículo de comunicação e o maior elo de ligação entre os pólos produtor e consumidor, pode ser considerada uma grande oportunidade mercadológica (Seragini, 1990). O entendimento entre a linguagem empregada nas embalagens de alimentos e a expectativa dos consumidores levam à comunicação e, consequentemente, à concretização de um dado comportamento.

Cabe ressaltar que, desse conjunto de informações, alguns aspectos são utilizados como estratégia de marketing, compreendendo o lado promocional da embalagem. A oferta do binômio produto/ embalagem segundo os modernos e seguros conceitos de qualidade (integridade, interação de componentes fundamentais etc), preceitos legais e econômicos (produção adequada ao volume de matéria-prima e de pedidos formulados, tecnologia, logística etc) podem gerar um fator de diferenciação para atender os mais exigentes consumidores, bem como representar uma vantagem competitiva para a segmentação de novos centros convergentes de mercado (Moreira, 1994 e Müller, 1994).

Os preceitos apresentados anteriormente estão associados à marcante alteração no ambiente empresarial. Segundo Silverstein (1992), com a globalização da economia, o planejamento estratégico das grandes corporações concentra esforços para conhecer as necessidades do novo público consumidor, aprimorar o processo de manufatura e de logística dos itens produzidos, acompanhar as tendências do mercado consumidor e, assim, gerar novos bens e serviços com maior rapidez e por um preço menor. Identifica-se, portanto, uma redução no ciclo de vida dos bens de consumo em geral.

Em uma entrevista fornecida à revista HSM Management, Kotler (1997) destaca a questão da dicotomia existente entre a centralização da globalização e a descentralização local. Nesse sentido, o autor comenta que produtos como, por exemplo, câmaras fotográficas podem ser vendidos de forma altamente padronizada. Por outro lado, ressalta que os gêneros alimentícios precisam ter os items sabor, embalagem e publicidade ajustados aos diferentes mercados em que serão comercializados. Em um estudo desenvolvido por Dawar e Parker (1994) sobre os universos do marketing como sinais de qualidade do produto, também foi debatida a questão de um comportamento adaptado ou padronizado, conforme as necessidades identificadas que subsidiarão a formulação de estratégias internacionais de marketing. 
Ainda, segundo a mesma linha de abordagem, Luqmani, Yavas e Quraeshi (1994) relacionaram o conceito do pensamento global e da ação local com a adoção de uma estratégia consistente, cuja implementação no mercado estaria voltada para a imagem da continuidade, ou seja, uma estratégia que mantivesse cativo o público consumidor ao longo do tempo.

A adoção de um trabalho sistematizado e voltado para o aprimoramento da linguagem inserida nas embalagens de alimentos, poderia representar um eficiente esforço de marketing, no sentido de manter os consumidores existentes e/ou conquistar novos usuários, além de gerar lucro e reconhecimento para a empresa. Alguns exemplos serão apresentados, para mostrar as vantagens de um estudo mais detalhado e com a preocupação voltada para o aperfeiçoamento da inserção das denominadas "chamadas" nutricionais nos rótulos dos gêneros alimenticios, de acordo com os hábitos alimentares valorizados pelos seus usuários.

O desenvolvimento de estudos com consumidores britânicos, conforme pesquisa realizada por Wheelock (1992), constatou que esse público consumidor passava a se preocupar com o custobeneficio de um produto, ao estar disposto a pagar mais caro por um item, desde que o mesmo fornecesse vantagens relativas ao preenchimento das recomendações nutricionais consideradas adequadas. Segundo Williams (1993) e Demetrakakes, Bordenaro e Spaulding (1994), modificações na composição do conteúdo informativo e/ou o emprego de um sistema que facilite a interpretação das informações escritas ou gráficas referentes ao valor nutricional do produto poderão ajudar o consumidor britânico a reconhecer, de maneira mais clara e objetiva os valiosos itens e correlacioná-los às suas necessidades diárias. Os aspectos identificados durante a realização desses estudos, mostram que o desconhecimento do padrão de compra do consumidor, bem como as tendências de mercado (Bartlam, 1993), podem gerar conflitos e comprometer a decisão a ser tomada.

Os resultados obtidos com uma pesquisa realizada com consumidores norte-americanos, vêm exemplificar de que forma a disposição das informações inseridas nas embalagens de alimentos pode afetar o comportamento do consumidor. Ficou evidenciado que a presença de descritores do produto, na parte frontal e no verso da embalagem, alteravam a decisão de escolha em comparação àquelas embalagens que continham as informações em, apenas, um dos lados do invólucro protetor (Hrovat, Harris, Leach, Russell, Harris e Sprecher, 1994).

Assim, para Kraft e Goodell (1993), em pesquisas realizadas nos Estados Unidos, o aprimoramento do conteúdo informativo das embalagens de alimentos poderia conduzir à segmentação de mercados e à identificação de específicos centros de convergência de operações comerciais.

As considerações apresentadas, a partir de estudos realizados com consumidores norteamericanos e britânicos, ressaltam a existência de uma estreita relação entre produto, fornecimento das informações expressas nas embalagens de alimentos e a explicitação de um 
comportamento seguro quanto à tomada de decisão pela compra ou não de um determinado item alimentício.

Portanto, cabe ressaltar que as embalagens de alimentos, através do seu conteúdo informativo, transmitem mensagens, que podem influenciar ou desencadear práticas de consumo. Forma-se, assim, um canal aberto de comunicação entre produtor/ produto/ consumidor.

O tópico a seguir, apresentará a interligação existente entre as várias informações inseridas nos rótulos dos gêneros alimentícios, segundo uma abordagem sistêmica para o setor embalagem, bem como algumas implicações da mensagem transmitida por esse veículo de comunicação no comportamento do consumidor em geral.

\subsection{Abordagem Sistêmica da Embalagem no Processo da Comunicação}

A realização de um estudo científico (Castro, 1994), no contexto brasileiro, permitiu identificar evidências para a validação do conceito de uma abordagem sistêmica para a embalagem, mais especificamente, a embalagem de alimentos.

Essa abordagem identificou um conjunto de ações encadeadas, que ocorre desde a etapa de planejamento da embalagem de alimentos à sua posterior comercialização. Ficou evidenciada a interligação dos elementos contidos nesse veículo de comunicação entre os agentes produtor e consumidor, durante o processo de comercialização dos gêneros alimentícios. Portanto, além das funções básicas de conter, proteger, promover, transportar e identificar um produto (Bennett, 1988), a embalagem de alimentos contribui, com certa parcela, para a formação de opinião dos consumidores, ao exercer um papel educativo (Testin e Vergano, 1991). Nesse mesmo estudo, mencionado anteriormente, constatou-se que a linguagem inserida nos rótulos das embalagens de alimentos decorre do envolvimento de vários profissionais de diversas áreas funcionais internas e externas à empresa. Através de um conjunto de informações presente na embalagem é que se dá o processo de comunicação entre produtor/ produto/ consumidor, no momento da tomada de decisão por um determinado item.

A embalagem de alimentos mantém um canal aberto de comunicação (Boroni, 1975) com os vários níveis de troca do sistema econômico. Assim, o conteúdo informativo inserido nos rótulos das embalagens de alimentos precisa estar em consonância com o entendimento do consumidor, de tal forma, que o usuário possa tomar sua decisão com segurança, bem como empregar o produto dentro das suas expectativas e necessidades.

Para que essa meta seja alcançada, leva-se em consideração a interdependência dos aspectos normativos, promocionais, mercadológicos e educativos na definição das etapas de planejamento e desenvolvimento das embalagens dos produtos alimentícios. Tem-se, assim, uma visão global a respeito da abordagem sistêmica para a embalagem de alimentos. Esse veículo de comunicação é 
um agente de estímulo tão diversificado no mercado, que ao transmitir mensagens, está, também, se comunicando com o consumidor.

A inserção da abordagem sistêmica no contexto empresarial poderá subsidiar a adoção de um marketing globalizado, pois segundo Olsen e Granzin (1994), niveis de desenvolvimento econômico afetam a estrutura natural de distribuição, ao promover uma integração vertical entre os canais formados pelo marketing. $O$ constante aprimoramento das atividades ligadas à utilização de recursos, processamento, embalagem, logistica e áreas de apoio, aliados à adaptação da marca do produto ao gosto e necessidade do público-alvo identificado, permitiria o alcance da esperada e denominada "excelência empresarial" (Brimson, 1991, p.5).

No próximo item, serão apresentadas questões sobre o conteúdo informativo inserido nos rótulos das embalagens de alimentos, expondo, gradativamente, a complexidade do problema e alternativas estudadas para se obter uma linguagem mais próxima das necessidades diárias do consumidor em geral, segundo as recomendações sugeridas em artigo publicado pela revista Food Technology (1992).

\subsubsection{Relação entre o consumo do alimento e seus beneficios na saúde pública}

Com base nas assertivas apresentadas anteriormente, observa-se a complexidade do assunto em questão, principalmente, no aspecto relativo à escolha de um produto que possa atender aos mais diversos niveis de interesse dos consumidores, tais como: preocupação com o culto à forma, ingestão de uma alimentação considerada saudável, ou ainda, preencher as recomendações de uma dieta indicada em casos de problemas de saúde, advindos ou não do fator idade. Neste item do trabalho, são destacados estudos, recentemente realizados, com o objetivo de propor alternativas que ajudem o consumidor a compor dietas adequadas às suas necessidades, a partir das informações inseridas nas embalagens de alimentos.

Nos Estados Unidos, uma das preocupações é a utilização de "chamadas" nutricionais, sobretudo nas embalagens denominadas unidades de consumo. Para Erickson (1990) e Taylor (1995), o elemento-chave de muitas embalagens de alimentos é a segurança conferida pela informação, ao permitir que o consumidor norte-americano possa tomar uma decisão considerada ideal. Para que essas informações preencham satisfatoriamente as expectativas e necessidades desse consumidor, Yetley e Park (1995) ressaltam que a "Food and Drug Administration", órgão responsável pela normatização de medicamentos e alimentos, vem desenvolvendo trabalhos no sentido de normatizar e padronizar a linguagem expressa nas embalagens dos gêneros alimentícios.

Cabe enfatizar que a população tem adotado práticas alimentares diferenciadas, ao reduzir a ingestão diária de gordura (Reid e Hendricks, 1994). Dessa forma, os termos "não contém colesterol", "baixo teor de gordura saturada" e "sem gordura hidrogenada", são informações contidas nas embalagens de alimentos e que, nem sempre, são claramente entendidas pelo consumidor. 
$O$ interesse pelo assunto, entre os pesquisadores norte-americanos, tem sido tão grande, que além de alterações na composição e configuração das informações advindas dos seus componentes nutricionais (Tollefson, 1994), foi desenvolvido um programa de computação (Zarkin, Dean, Mauskopf e Williams, 1993) para estimar os beneficios decorrentes da redução da ingestão dos nutrientes relacionados ao nível total de gordura, colesterol e gordura saturada na saúde pública.

Com relação aos dados sobre o comportamento de compra da população norte-americana extraídos da literatura existente sobre o tema em questão, observa-se uma preocupação dos estudiosos, em aprimorar, cada vez mais, os avanços obtidos no sistema de rotulagem de alimentos manufaturados nos Estados Unidos (Erickson, 1990; Steinman, 1992; Couig, 1993). No Brasil, na busca realizada pela autora deste trabalho, constatou-se uma escassez de estudos com essa abordagem. Nesse sentido, cabe destacar o aspecto benéfico decorrente do desenvolvimento de uma pesquisa que possa identificar caminhos alternativos para aprimorar o sistema de rotulagem dos gêneros alimentícios brasileiros, segundo as necessidades do mercado consumidor.

Na América Latina, realizou-se um estudo sobre produto e embalagem pela Dil/ Research International/ Alusa (1994), com consumidores brasileiros e chilenos. Nesse trabalho foram considerados, entre outros, vários aspectos no que tange à instrução de uso, ingredientes, marca, datas de fabricação e validade do produto e a apresentação de um número de telefone, para contato com o Serviço de Atendimento ao Consumidor (SAC). Os resultados demonstraram que os elementos empregados para a realização da pesquisa são determinantes na tomada de decisão dos consumidores entrevistados. Entretanto, o consumidor brasileiro carece de trabalhos voltados para o conteúdo informativo das embalagens de alimentos, os quais possam indicar alternativas aos profissionais de marketing, que buscam identificar e traduzir as expectativas e necessidades dos consumidores em geral.

Levando-se em consideração o contexto de economias e de mercados de consumo globalizados, julgou-se oportuno realizar um estudo internacional comparativo sobre o comportamento de compra entre consumidores ${ }^{1}$ brasileiros e norte-americanos. Após o cumprimento dos requisitos necessários para a aprovação e concessão de uma bolsa denominada "Bolsa Sanduíche", por parte da agência brasileira (CAPES) voltada para a pesquisa científica, o desenvolvimento da porção norte-americana do estudo realizou-se na Georgia State University, cidade de Atlanta, estado da Georgia.

\footnotetext{
${ }^{1} \mathrm{O}$ termo consumidor se aplica ao consumidor final, propriamente dito, do produto (amparado pelo Código de Defesa do Consumidor). Isto é, aquele "que adquire o produto ou serviço para consumo e não para repasse ou uso para uma atividade geradora de outro produto ou serviço". Superhiper, $1991 ; 17$ (3):40.
} 


\subsection{Contribuições do Estudo}

$\mathrm{O}$ consumidor tem-se mostrado mais atento e mais exigente com a qualidade dos produtos, em virtude da amplitude de ofertas advindas da comercialização de itens nacionais e importados. $\mathrm{O}$ aprimoramento da embalagem de alimentos como veículo de comunicação trará beneficios ao consumidor, alternativas para as questôes ligadas aos problemas de saúde pública e, consequentemente, um lucrativo retorno advindo de um investimento em qualidade.

O conhecimento do comportamento de compra do consumidor é um dos pontos de partida para a segmentação de mercados, conquista de novos e específicos centros convergentes de operações comerciais, bem como para a aplicação de um conjunto de medidas alternativas e direcionadas para 0 atendimento das necessidades do mercado de consumo e, sobretudo, para a preservação da competitividade das empresas.

0 presente estudo analisou as estratégias adotadas pelo consumidor por ocasião da seleção, aquisição e uso dos alimentos, no que tange o conteúdo informativo das embalagens de alimentos. Nesse sentido, cabe ressaltar a relevância do estudo e o seu aspecto contributivo para os setores acadêmico e empresarial.

No que se refere às instituições acadêmicas, o caráter inovativo do trabalho, visto tratar-se de um estudo exploratório internacional comparado (EEIC) acerca do conteúdo informativo das embalagens de alimentos, segundo a ótica brasileira e norte-americana dos agentes de produção e consumo, é importante para a formação dos futuros profissionais com a atenção voltada para o marketing e para a saúde pública. $O$ desenvolvimento do estudo trouxe, portanto:

- enriquecimento ao conhecimento das práticas comerciais existentes na comunicação estabelecida entre produtores e consumidores;

- esclarecimento quanto às estratégias de marketing aplicadas à qualidade dos alimentos e sua importância sobre a saúde pública;

- contribuição conceitual com o aprimoramento do modelo sistêmico desenvolvido pela própria autora, ao ter sido submetido à apreciação de diferentes ambientes sociais, culturais e políticoeconômicos;

- aprimoramento do conhecimento acerca dos procedimentos metodológicos na realização de um estudo internacional comparado.

Para o setor executivo, os resultados alcançados ampliaram o conhecimento comparado sobre o processo de tomada de decisão, segundo a ótica dos agentes de consumo (aquisição ou não de um gênero alimentício) e produção (ações de Marketing, segundo as exigências do mercado consumidor) brasileiros e norte-americanos. 
Fica reconhecido que o consumidor tem-se mostrado mais atento e mais exigente com a qualidade dos produtos, em virtude da amplitude de ofertas advindas da comercialização de itens nacionais e importados. Reformulações, por categoria de produto, na definição e padronização do conjunto de informações contidas no "box" nutricional das embalagens de alimentos traria uma contribuição no aperfeiçoamento desse veículo de comunicação, alternativas para as questões ligadas aos problemas de saúde pública e, consequentemente, um lucrativo retorno advindo de um investimento em qualidade.

Assim, levando-se em consideração o fator da globalização, o desenvolvimento do presente estudo poderá subsidiar as atividades realizadas pelos profissionais do setor de embalagem de alimentos e das áreas de Marketing e saúde pública, bem como daquelas executadas pelos acadêmicos, pesquisadores e administradores em geral. $O$ tópico a seguir apresenta sua estrutura.

\subsection{Organização do Trabalho}

Além deste capítulo introdutório, outros quatro fazem parte do presente estudo. No Capítulo 2 estarão contidos os aspectos mais relevantes, extraídos da literatura disponível sobre o tema.

Levando-se em consideração as características do problema, optou-se por um estudo exploratório internacional comparado, cujas razões serão explicitadas no Capítulo 3. O mesmo Capítulo, mostra, também, os objetivos (Propósito e Foco do Estudo) do estudo e fornece, com maiores esclarecimentos, elementos para a elaboração e desenvolvimento da presente investigação.

O Capítulo 4 refere-se aos resultados e análises obtidos, de acordo com o objetivo central do estudo em questão.

Finalmente, conclusões, implicações, limitações e direcionamentos para estudos futuros são colocados no Capítulo 5.

\subsection{Referências}

Foram adotadas as normas seguidas pela Faculdade de Saúde Pública - USP, para denominar o tópico "REFERÊNCIAS", bem como para fazer a apresentação da bibliografia utilizada e que constitue o estado da arte do presente trabalho. 
CAPÍTULO 2

REVISÃO DA LITERATURA

SELECIONADA SOBRE O ASSUNTO 


\section{REVISÃO DA LITERATURA SELECIONADA SOBRE O ASSUNTO}

\subsection{Caracterização do Setor de Embalagem}

A embalagem' vem acompanhando, rapidamente, as exigências determinadas pelo mercado consumidor, ao desempenhar vários papéis que transcendem aqueles com a finalidade de proteger, promover, transportar e/ou identificar um produto. Atualmente, nos canais de distribuição denominados de "auto-serviço" são encontrados diversos tipos de embalagem, para facilitar o armazenamento, a reposição e a disposição dos produtos nas gôndolas; atender às exigências do público consumidor, no tocante à oferta de unidades de consumo e causar um impacto visual atraente e integrado ao cenário do ponto-de-venda (Tsumori, 1994).

Considerando-se os grandes temas tornados mais relevantes a partir da década de 90 , que compreendem os conceitos de globalização, meio ambiente e o aumento da competitividade, visualiza-se um impacto direto na forma como as empresas comercializarão os seus produtos através da embalagem. Dentre as inovações esperadas, além de um "centro de informação" expressa pela linguagem escrita, haverá a adoção de símbolos e figuras "universalmente entendidos", que farão parte da comunicação dos beneficios de um dado item. No segmento de produtos com alto valor agregado, como por exemplo, bebidas finas, café, entre outros, o emprego da holografia conduzirá à criação da embalagem tridimensional. E, finalmente, ao se buscar a percepção pelo benefício da compra, poderá surgir uma embalagem que tenha o seu volume reduzido à medida que o conteúdo seja retirado do invólucro protetor, permitindo melhores condições de armazenagem e estocagem nas áreas destinadas ao processo de reciclagem (Selame, 1993).

Segundo matéria publicada na revista Embanews (1997), a necessidade de conquistar a preferência do consumidor, principalmente nos dias de hoje, dentre uma diversificada gama de opções entre produtos nacionais e importados, bem como na identificação de profundas modificações no padrão de consumo e na cadeia de produção/ distribuição de bens, são elementos que vêm determinando a orientação do produtor para o consumidor. Concluindo, pode-se dizer que o emprego da embalagem é uma estratégia de melhoria global da eficiência da cadeia agro-industrial, pois esse veículo de comunicação vem a ser o elo de ligação existente nos sistemas de distribuição de alimentos do campo até o consumidor.

\footnotetext{
${ }^{1} \mathrm{O}$ termo se refere ao recipiente usado para proteger, promover, transportar e ou identificar um produto. O material do invólucro pode variar entre plástico, madeira, alumínio, entre outros. A embalagem primária contém o produto, a secundária uma ou mais embalagens primárias e a terciária pode conter uma ou mais embalagens secundárias. Bennett PD. Dictionary of marketing terms. Pennsylvania: The American Marketing Association; 1988, p. 140.
} 
A complexidade das necessidades da sociedade, a preocupação dos problemas sociais (Daniels, 1994), associados aos descritores nos rótulos ${ }^{2}$, indicando porção de consumo, percentual e gramagem das recomendações nutricionais (Lewis e Yetley, 1992), enfatizam que a embalagem de alimentos, através da sua linguagem, procura desempenhar, também, o papel educativo, no sentido de apresentar informações voltadas para os interesses relativos à saúde pública.

O conhecimento do comportamento de compra do consumidor e, sobretudo, o reconhecimento e o atendimento a uma estrutura ordenada de preferência dos atributos de um bem de consumo irão refletir os investimentos aplicados no aprimoramento de métodos e processos, voltados para a qualidade do binômio produto/ embalagem e para a oferta de itens diferenciados e competitivos, segundo as exigências de um ambiente empresarial globalizado, os quais poderão proporcionar um retorno lucrativo à empresa.

Por intermédio da embalagem de alimentos será possível avaliar a satisfação do consumidor, a participação do produto no mercado, identificar a relação entre qualidade e lucro e estreitar, ainda mais, a comunicação entre produtor e consumidor. Dessa forma, destaca-se a necessidade de um trabalho conjunto que busque aproximar, cada vez mais, os avanços do campo tecnológico da gradativa e abrangente evolução social do homem e, consequentemente, a criação de novos mercados de consumo.

\subsubsection{A embalagem na economia de mercado e a dinâmica do setor de alimentos}

A embalagem é considerada uma espécie de termômetro da economia, pois é por intermédio do desempenho desse setor, que são avaliadas as condições do mercado. Esse veículo de comunicação contribui para a composição do custo de cada produto e, dependendo da sua qualidade, a comercialização do bem de consumo poderá ser afetado. Segundo as estatísticas registradas no ano de 1993, por exemplo, a produção geral de embalagens dos gêneros alimentícios apresentou um aumento em torno de 5-6\% (Oliveira, 1993).

De acordo com os dados publicados em uma edição especial da revista Embanews - Guia de Embalagem (1995) e obtidos pelo Instituto Brasileiro de Geografia e Estatística (IBGE), o faturamento da indústria de alimentos eqüivale a $10,5 \%$ do Produto Interno Bruto (PIB). Esses dados são de suma importância para o setor de embalagens, pois a indústria alimentícia absorve cerca de $60 \%$ de toda a produção de embalagens, gerando uma diversidade muito grande de invólucros como latas, caixas de papelão e de cartão, recipientes plásticos e de vidro, embalagens múltiplas, cartonadas e industriais.

\footnotetext{
${ }^{2}$ Rótulo é a informação fixada sobre o produto com o propósito de nomeá-lo, descrever e advertir quanto ao uso, indicar ingredientes, produtores e o sabor. No sentido amplo, caracteriza uma norma que alia a informação promocional à estritamente relacionada ao produto. Bennett PD. Dictionary of marketing terms. Pennsylvania: The American Marketing Association; 1988; p. 104.
} 
Conforme materia publicada na revista Embanews (1994), o mercado brasileiro de embalagem produziu em 1992 cerca de 3,7 milhões de toneladas, o equivalente a US\$ 5,325 milhões de dólares. Esses dados representam um valor aproximado de 1,5\% do PIB - Produto Interno Bruto. Do total de matéria-prima produzida, os segmentos de papel e papelão ondulado e ligas metálicas apresentaram um consumo de $35,1 \%$ e $24 \%$, respectivamente.

Segundo dados fornecidos pela Associação Brasileira das Indústrias da Alimentação - ABIA, em matéria publicada pela revista F\&C Embalagem (Benzi, 1994), o setor de alimentos, entre outubro de 92 e outubro de 93 , cresceu $4,7 \%$ em relação ao mesmo período de 91/92. Esses dados sugerem que o mercado alimentício é impulsionado por "substituição de demanda" e não por queda de "demanda" (p. 74). O consumidor troca um alimento por outro sempre em busca de opções favoráveis ao seu poder aquisitivo.

Conclui-se, portanto, que o setor de embalagem tem seu papel de destaque no segmento de alimentos, pois é através dela que a indústria alimentícia pode decodificar as necessidades e os desejos do consumidor e criar, assim, novas e significativas oportunidades para o próprio setor alimentício.

\subsubsection{Abordagens conceituais}

A embalagem, ao envolver um produto, está desempenhando a função de conter, guardar e armazená-lo, desde a sua fase de produção, até o momento de seu uso pelo consumidor final (Nazário, 1985). Ao mesmo tempo que exerce este papel fundamental, a embalagem precisa ter a capacidade de "vender-se ao consumidor, ser distinguida das concorrentes, ter habilidade de levar o consumidor a desejar e a comprar o produto", bem como "sustentar e completar a imagem criada pela propaganda" (Vowler, 1979, p. 9).

Além de ser um invólucro protetor, a embalagem pode ser considerada um elemento motivador de emoções (Dichter, 1975), quando desperta no consumidor o sentimento pela busca do novo e desconhecido. Por intermédio da linguagem, o consumidor sente-se emocionalmente motivado a efetuar ou não uma compra. Esse veículo de comunicação também é considerado como sendo um "símbolo de esforço total de marketing", que passa a ser o próprio produto num comercial de cinco segundos e representa, muitas vezes, a "única evidência visual e tangível do que se está tentando vender" (Gerstman, 1987, p. 36).

Segundo Parcels (1987), a embalagem é uma das peças do marketing que tem a faculdade de posicionar e/ou avaliar o impacto de um bem no mercado de consumo, ao estabelecer segmentos de consumidores, criar ou reforçar a imagem do produto, aumentar o lucro, a distribuição, bem como enfrentar concorrentes.

Em uma das raras obras dedicadas especificamente a este tema, Guss (1967) enfatiza que as embalagens desempenham, de modo geral, funções básicas que envolvem desde a proteção fisica do produto durante as etapas de armazenagem, transporte e manuseio do produto, ao suprimento 
dos itens nos pontos de comercialização, viabilizando, mais especificamente, o sistema de troca e venda das unidades de consumo. Para bem desempenhar a função de venda de um item, a embalagem precisa estar em constante consonância com as mudanças ocorridas na sociedade. $\mathrm{E}$ para tal, utiliza-se da informação, nela inserida, como um suprimento facilitador para o desempenho dessa função.

A embalagem adquire o papel de "vendedor silencioso", principalmente, nos supermercados, um dos mais importantes canais de distribuição do tipo auto-serviço. Neste caso, o conjunto informativo contido nas embalagens de alimentos viabiliza a promoção e a venda dos produtos, além de servir, informar e educar o consumidor.

No processo de informação-aprendizagem, fica reconhecida a importância do detalhamento, cuidadoso, das informações nutricionais ("chamadas", alerta às notas explicativas), como eficiente e econômica medida de educação e proteção do consumidor (Miller, 1978).

Em termos mundiais de consumo, Luqmani, Yavas e Quraeshi (1994) consideram a conveniência um fator comum que pode fornecer úteis subsídios na estruturação de um planejamento estratégico global. Ainda, segundo esses estudiosos, o redesenho de um produto, bem como uma embalagem criativa são opç̃es que proporcionam conveniência tanto para o consumidor como para o cliente, podendo ser disponibilizada para ambos sem a necessidade do emprego abundante de recursos financeiros.

Além dos aspectos conceituais mencionados anteriormente, verifica-se, também, que a composição gráfica da embalagem vem sendo empregada como um veículo, por intermédio do qual ocorre o desafio para se consolidar a marca do produto, ou seja, estabelecer, identificar e comunicar o posicionamento da marca no mercado. De acordo com matéria publicada pela revista Embanews (1997), a embalagem é a face do produto, que ao combinar estrutura e grafismo representa um simbolo tridimensional da marca, isto é, saúda o consumidor na prateleira, transporta a mensagem e mantém a comunicação com o consumidor até a ocasião do uso/ consumo do produto pelo usuário.

Com base na transcrição das considerações apresentadas pelos estudiosos no campo da embalagem, pode-se concluir que os aspectos levantados ressaltam a embalagem como um poderoso instrumento de marketing, sobretudo durante o processo de comercialização de bens de consumo, em especial os alimentos.

A seguir, será feita uma abordagem sobre a embalagem de alimentos e as tendências no comportamento do consumidor durante o processo da comercialização de gêneros alimentícios.

\footnotetext{
${ }^{3}$ Termo utilizado para caracterizar uma das funções da embalagem de alimentos em sua evolução histórica. Seragini L. O universo da embalagem. Marketing, 1984; 17(124):19-34.
} 


\subsection{Embalagem de Alimentos e o Comportamento do Consumidor}

\subsubsection{Consideraçōes gerais}

Atualmente, a "Tábua de Vida" vem aumentando gradativamente e, associada a essa maior expectativa de vida, são observadas mudanças no comportamento dos seres humanos. Em virtude de uma maior concentração de pessoas idosas, os custos com a saúde dessa população sofrem uma acentuada elevação. As pessoas passam a se preocupar mais com os conceitos de melhoria do padrão de vida (bem-estar psicológico, mental, condicionamento físico, entre outros) e começam a adotar práticas alimentares diferenciadas, bem como a administrar situações de estresse. Assim, o mercado tem o seu enfoque voltado para essa tendência de estilo de vida com padrões de comportamento de compra específicos e segmentados (Kraft e Goodell, 1993).

A publicação de um artigo escrito por Erickson (1990) mostrou que, segundo os pesquisadores Corey e Bone, modificações no tamanho da letra das informações contidas nos rótulos das embalagens de alimentos e a veracidade dessas informações trariam beneficios aos aspectos voltados para os problemas de saúde pública. Essas medidas estariam abrangendo a população em geral e, sobretudo, as pessoas idosas que, além de muitas vezes terem dificuldade de ler rótulos de embalagens, podem apresentar problemas de saúde, que limitem o seu poder de escolha dentre as ofertas de gêneros alimentícios encontrados no mercado.

Cabe ressaltar que, entre as mudanças ocorridas nos hábitos alimentares, a redução no consumo de gorduras e a preocupação com as "chamadas nutricionais" sobre a presença ou não de colesterol na composição dos alimentos têm sido detectadas (Reid e Hendricks, 1994) no comportamento de compra dos consumidores norte-americanos em geral. Entretanto, percebe-se que algumas confusões são cometidas por parte desse consumidor, quando se trata de conceitos mais específicos, como por exemplo, a diferenciação entre o teor total de gordura e aquelas de origem "saturadas", "insaturadas", "hidrogenadas", existentes na composição do produto.

Associado ao novo padrão de hábitos alimentares, destaca-se o consumo de cereais enriquecidos com frutas, vitaminas e minerais, como componente do desjejum, pois aliam os beneficios de uma alimentação sadia à conveniência do rápido preparo. Esse comportamento vem sendo praticado por adultos da população britânica, conforme matéria publicada pela revista Retail BusinessMarket Reports (1993).

Medidas alternativas que trouxessem o aprimoramento desse veículo de comunicação, poderiam prevenir doenças (Steinman, 1992) relacionadas à obesidade e hipertensão, entre outras, permitindo que o consumidor comparasse o conteúdo nutricional com relação às porções de consumo diário e fizesse, assim, a escolha por uma dieta saudável e dentro das recomendações consideradas adequadas. $\mathrm{O}$ conjunto de informações expresso nas embalagens de alimentos

\footnotetext{
4 Tábua de Vida ou de Sobrevivência é o termo utilizado para estimar a vida média ou a esperança de vida de uma dada população. Laurenti R, Mello Jorge MHP, Lebrão ML, Gotlieb SLD. Estatísticas de Saúde. $2^{\text {a }}$ ed. São Paulo: EPU; 1987. p.147.
} 
poderia ser um útil instrumento para prevenir problemas de saúde (Couig, 1993) e, ao mesmo tempo, exercer um papel educativo na definição de hábitos alimentares.

As assertivas mencionadas anteriormente retrataram a dinâmica do comportamento do consumidor, especialmente em seu procedimento na busca por informações e esclarecimentos, nas embalagens, por ocasião da compra e consumo de gêneros alimentícios, que estão diretamente relacionados a suas necessidades e desejos. Nesse sentido, o comportamento da população vem assumindo conteúdo e significados mais complexos, o que permite o surgimento de um segmento inovador, capaz de apresentar uma visão global, com relação a uma associação entre estado fisico-mental e um dado estilo de vida (Santos, 1991).

Verifica-se, portanto, que o consumidor vem se transformando rapidamente, o que leva as empresas a se tornarem mais ágeis, sobretudo o setor de embalagens, no sentido de buscar satisfazer exigências cada vez maiores, com preços mais competitivos. Para atender a gostos e costumes diferenciados, percebe-se que o mercado passa a atuar em nível regionalizado. Concluindo, de acordo com uma matéria publicada na revista Embanews (1997), a sobrevivência das empresas, hoje em dia, está estreitamente relacionada com os aspectos porte e eficiênca, bem como com a adoção de uma estratégia voltada para específicos centros convergentes de negócios.

No tópico a seguir, será feita uma abordagem sobre os aspectos conceituais relativos ao comportamento do consumidor.

\subsubsection{Aspectos conceituais e o comportamento do consumidor}

\subsubsection{Considerações gerais}

O estudo sobre o comportamento do consumidor deve levar em consideração as características individuais do ser humano, as variáveis que podem influenciá-lo no processo de aquisição de bens e serviços, bem como os fatores relacionados com o modo de vida dos indivíduos estabelecidos em estruturas organizadas socialmente (Engel, Blackwell e Miniard,1990).

Com o processo da globalização, o fluxo de informações às quais os seres humanos estejam expostos é muito mais rápido e poderá contribuir para a formação de um novo estilo de vida. Para Gade (1980), torna-se imprescindível conhecer a cultura de uma dada sociedade, bem como o processo de socialização (herança e aculturação), isto é, como os membros de uma sociedade vão adquirindo um conjunto de padrões de respostas, que regulam as suas ações em geral e, em especial, aquelas relacionadas à prática de consumo. Dessa forma, é possível dizer que a cultura compreende um conjunto de padrões de respostas que foi transmitido ao individuo durante a sua socialização, ou aprendidos pela aculturação, os quais regulam e facilitam as ações dos membros de uma sociedade. De acordo com Chapman (1992) apud Tayeb (1994), esse conjunto de padrões de respostas caracterizam uma nação por intermédio dos valores, atitudes e significados aprendidos e compartilhados pelos indivíduos. 
Esse processo de aprendizado é dinâmico, em virtude de uma constante reordenação das instituições às quais o ser humano pertence. Assim, a adoção de estratégias de marketing que visam a estabelecer a comunicação entre a linguagem e a simbologia empregadas pela publicidade e o complexo de valores, atitudes, conhecimento e símbolos próprios de cada indivíduo, podem identificar as mudanças de hábitos de consumo e permitem o entendimento de padrões específicos de comportamento dos vários segmentos sociais.

Além dos fatores mencionados anteriormente, o fenômeno consumo conta com a presença do estímulo motivador durante a comercialização de bens de consumo. Dependendo do grau de envolvimento do consumidor com o produto a ser adquirido, as informações recebidas darão origem ao processo de aprendizagem e irão determinar as respostas comportamentais, como evidência da ocorrência da comunicação (Canton, Grisi e Santos, 1989a e 1989b). Por exemplo, pode-se considerar como estímulo a linguagem veiculada pelas embalagens de alimentos, que pode influenciar o consumidor acerca de suas atitudes sobre a mensagem transmitida. E no processo de tomada de decisão, o resultado pode ser a opção pela compra ou não do produto.

Segundo a opinião do profissional (Simas, 1994) de uma agência especializada em desenvolvimento de embalagens, o binômio produto/ embalagem participa do processo da comercialização de bens de consumo como um estímulo gerador de uma compra. Decorrente do processo de compra-recompra de um item de consumo, pode-se obter o estabelecimento da marca no mercado, desde que o consumidor tenha as suas necessidades atendidas. Assim, o processo de comunicação entre produtor e consumidor pode ser caracterizado pelos fatores embalagem-compra-consumo-intenção de recompra.

Para o bom desenvolvimento da cadeia de consumo, o consumidor que vai ser alcançado pela publicidade precisa ser conhecido. $O$ profissional de marketing irá analisar e aplicar as estratégias voltadas para o seu público alvo, de tal forma que os aspectos ligados aos seus valores, às suas atitudes, crenças e percepções, sejam devidamente respeitados.

O melhor conhecimento do consumidor permitirá descobrir outros elementos-chave além das influências ambientais, diferenças individuais e processos psicológicos na tomada de decisão, bem como visualizar o sistema organizacional que estabelece as relações entre as diversas partes do processo. Um estudo abrangente sobre os hábitos de consumo do consumidor permitirá identificar as possíveis alterações necessárias que funcionam em benefício de um bom desempenho do mercado.

\subsubsection{A teoria do comportamento do consumidor}

$\mathrm{O}$ assunto em questão é bastante complexo e necessita de esclarecimentos de estudos estreitamente ligados ao campo da sociologia, psicologia, antropologia etc. Dessa forma, na área do comportamento do consumidor, devem ser consideradas as variáveis que exerçam influências sobre o individuo no processo de aquisição de bens e serviços, bem como as questões relacionadas com o modo de vida em estruturas organizadas socialmente. 
Neste sub-item do estudo, ressalta-se a necessidade de, em primeiro lugar, esclarecer a importânica da cultura no comportamento organizacional, bem como sua influência em questões de gerenciamento de recursos humanos. Nesse sentido, segundo Tayeb (1994), a maior força da perspectiva cultural como um todo é o seu reconhecimento acerca dos seguintes fatos:

- os valores e as atitudes culturais são diferentes em grau, pelo menos, se não em termos absolutos, em alguns casos, de uma sociedade para a outra;

- grupos culturais comportam-se de forma diferenciada sob circunstâncias similares, por causa das diferenças ressaltadas em termos de valores e atitudes;

- o importante papel que a cultura desempenha na formação de organizações de trabalho e de outras instituições sociais.

Tayeb (1994) considera que, o claro entendimento sobre o termo cultura é fundamental para a compreensão das variações encontradas no comportamento organizacional em termos mundiais, bem como para permitir delinear contrastes entre organizações diferentes e que estão estabelecidas em várias partes do mundo. Nesse sentido, ainda segundo a pesquisadora mencionada, encontra-se na literatura abundante sobre $o$ assunto, as seguintes definições sobre $o$ termo cultura:

- combinação de normas, valores, sentimentos, pensamentos, papéis, regras, comportamento, crenças, atitudes, expectativas, significados, entre outros;

- ou, cultura é entendida como o que não está incluído nas esferas econômica, política, legal, religiosa, educativa, tecnológica, ambiental, entre outras.

A influência da cultura se estende às questões relacionadas às tomadas de decisão e às ações de consumo. Os valores denominados valores centrais ou "core values" (Engel, Blackwell e Miniard, 1990) determinam a prática de consumo de uma sociedade. De acordo com os dados encontrados na literatura sobre os universos do marketing (marca, preço, aparência e reputação do varejista) como sinais da qualidade do produto e, segundo o parecer de Dawar e Parker (1994), cabe ressaltar que esses elementos podem representar uma universalidade menor, para os gêneros alimentícios. Segundo os pesquisadores mencionados, o comportamento do consumidor, para essa categoria de bens de consumo, tem sido determinado por uma cultura mais confinada (específica) às características de uma dada localidade. Assim, para analistas do comportamento do consumidor o amplo conhecimento dessas variáveis é imprescindível.

Nos sistemas comportamentais, a cultura desempenha um importante papel, é difusa e conduz para vários comportamentos de adaptação por intermédio de sua própria assimilação e integração. Dessa forma, explicita ideologia e/ou valores culturais de formas de comportamento. Tse, Belk e Zhou (1989) e Metha e Belk (1991) desenvolveram estudos com objetivo centrado no conteúdo "cross-cultural". Esses estudiosos procuraram examinar valores de consumo com consumidores asiáticos (Hong Kong, China, e Taiwan) e imigrantes indianos residentes nos Estados Unidos. 
Em virtude de aspectos como grau de instrução, experiências adquiridas ao longo da prática exercida, mudanças ocorridas na estrutura das instituições primárias e secundárias, influência dos pares que se manifesta presente, bem como em função do próprio processo de aprendizado do consumidor, esses valores centrais podem ser reordenados ao longo do tempo.

Portanto, a adoção de estratégias de marketing que pretendam acompanhar as mudanças de hábitos de consumo, precisam levar em consideração padrões específicos de comportamento dos vários segmentos sociais, de tal forma que se processe a comunicação entre a linguagem e a simbologia empregadas na publicidade e o complexo de valores, atitudes, conhecimentos e símbolos próprios de cada individuo. O profissional da área de marketing, para bem desempenhar suas atribuições, não deve perder de vista a necessidade de realizar pesquisas, com a finalidade de conhecer os grupos sociais que irão situar geograficamente o alvo de seus estudos, que é o consumidor.

Cabe ressaltar que, nem sempre, o consumidor tem condições e habilidade para formular, mensurar e escolher a alternativa considerada a ideal. A utilização de uma linguagem organizada $e$ apresentada de forma clara sobre os atributos de um produto, retrata todo o trabalho do profissional de marketing. A identificação das necessidades do consumidor, bem como a veiculação da informação e orientação quanto às características e aos beneficios do produto na composição de uma dieta alimentar, permitirão que o consumidor possa fazer sua escolha com maior segurança.

\subsubsection{O aspecto "cross-cultural"}

A realização de um estudo que engloba o aspecto da troca de cultura ou "cross-cultural" poderá apresentar problemas e obstáculos relacionados às questões de conceitualização, operacionalização, levantamento das informações, bem como quanto à interpretação dos dados obtidos, os quais precisarão ser adequadamente considerados pelo pesquisador. De modo geral, esse tipo de estudo permite avaliar como as organizações de um determinado país vêm a influência de instituições de outra nacionalidade sobre o seu comportamento padrão adotado, isto é, sobre os significados que vêm sendo atribuídos pelos membros constituintes de uma dada sociedade.

No que tange ao fator conceitualização, Chapman (1992) apud Tayeb (1994), ressalta em suas considerações, que o desenvolvimento de estudos que tragam em seu escopo a questão denominada troca cultural deve abordar, além do termo cultura, os aspectos relacionados com religião, idioma e demais conceitos julgados necessários pelo pesquisador para o entendimento analítico dos fatos estudados. A identificação de diferenças na estrutura de palavras e conceitos vem a ser um instrumento para medir, em amplo senso, como é vivida e entendida, pelas pessoas, realidades contrastantes entre duas sociedades. 
Quanto à parte operacional, encontra-se na literatura (Tayeb, 1994) a preocupação com uma investigação, que englobe uma análise fundamentada em descobertas decorrentes do evento e não baseada apenas em fortes evidências. Nesse sentido, segundo Hofstede (1984) apud Tayeb (1994), o desenvolvimento de um estudo deve examinar o papel da cultura (sua consistência) e, portanto, sua influência sobre o comportamento humano. Dentre as dimensões existentes, destacam-se a questão da igualdade/ desigualdade social, a busca pela estabilidade/ previsibilidade, os aspectos voltados para o binômio individualismo/ coletivismo, bem como aqueles relacionados com a masculinidade/ feminilidade. Verifica-se, assim, que essas dimensões culturais acabam determinando a maneira pela qual as organizações são estruturadas e organizadas.

Dependendo da ênfase atribuida pelos indivíduos a cada uma dessas dimensões, encontrar-se-á um correspondente comportamento do público consumidor no momento da aquisição de bens e serviços. Com o intuito de exemplificar as considerações mencionadas, utilizar-se-á um estudo (Roth, 1995) realizado com o objetivo de identificar os efeitos sócio-econômicos e culturais no desempenho das estratégias globais acerca da imagem da marca para o consumidor. Segundo Roth (1995), a estrutura conceitual é capaz de identificar uma série de características ambientais, culturais e sócio-econômicas em mercados estrangeiros, as quais podem afetar o desempenho da imagem da marca. Ao procurar entender a ligação existente entre o ambiente do mercado e o preenchimento (satisfação) das necessidades do consumidor, identifica-se o papel desempenhado pela marca por intermédio do significado atribuido às imagens funcional (prevenir e solucionar problemas), social (afiliação, pertencer a um grupo) e sensorial (busca pela variedade, novidade e gratificações sensoriais). A Figura 2.2.2.3 relaciona o desempenho das estratégias desenvolvidas para a imagem da marca com os fatores culturais e sócio-econômicos de mercados internacionais.

Essa representação mostra, de modo geral, um modelo conceitual de efeitos potenciais e moderados da cultura, bem como dos aspectos sócio-culturais sobre o desempenho das estratégias da imagem da marca. Verifica-se que, em mercados internacionais, as características ambientais exercem um papel moderador nas relações existentes entre o desempenho funcional, social e sensorial da imagem da marca, por intermédio de duas características: cultura nacional e condições sócio-econômicas regionais. 
Figura 2.2.2.3 Os efeitos sócio-econômicos e culturais sobre o desempenho das estratégias globais da imagem da marca

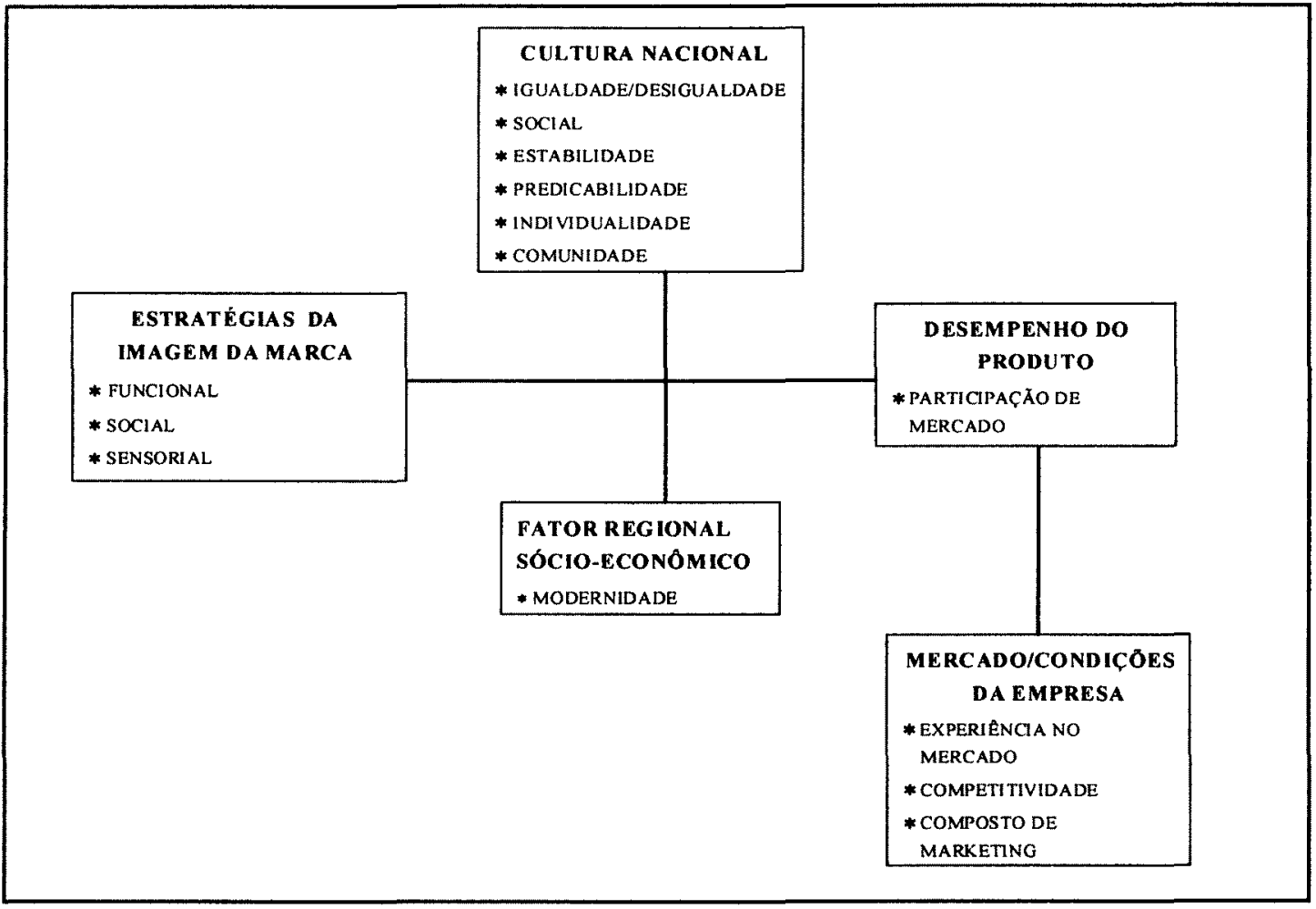

Fonte: ROTH, Martin S. The effects of culture and socioeconomics on the performance of global brand image strategies. J Mark Res, 1995; 22:163-75.

O impacto da cultura, de acordo com as descobertas obtidas por Hofstede (1984) apud Roth (1995), acerca do comportamento do consumidor em relação à imagem da marca de um dado produto, pode exercer as seguintes influências sobre o desempenho das estratégias globais aplicadas:

- igualdade/ desigualdade social: em sociedades que valorizam o prestígio e a fortuna, verifica-se que as pessoas procuram manter e aumentar o seu poder como uma fonte de satisfação. Neste caso, a consciência social é alta e os indivíduos são motivados pela necessidade reconhecida, também, pelos seus pares (da mesma classe social), ou identificada nas classes sociais às quais almejam alcançar. Quando é baixa a ênfase pelo prestígio e pela fortuna, as pessoas estão menos preocupadas com diferenças e aspirações sociais. Ou seja, a motivação existente está altamente relacionada com as normas de afiliação e, consequentemente, com o "status social". Nesse sentido, é valorizada pelo consumidor a imagem social da marca de um bem de consumo.

* busca pela estabilidade/ previsibilidade: quando os indivíduos de uma dada sociedade enfatizam o fator estabilidade, existirá uma aversão à inovação e, portanto, um comportamento de prevenção na solução de problemas, ou seja, apresentam aversão ao sentimento de risco. Os consumidores com este tipo de comportamento serão bons candidatos a destacar a imagem funcional da marca de um produto. Ao contrário, quando a ênfase dada à estabilidade/ 
previsibilidade for baixa, os consumidores estarão pre-dispostos à diversificação de ofertas (novidades no mercado), pois o sentimento de risco encontra-se diminuído. Neste caso, o consumidor valoriza a imagem sensorial da marca pois os fatores variedade, novidade e gratificações sensoriais são afetados por esse público consumidor.

- individualismo/ coletivismo: o comportamento característico de sociedades individualistas é a valorização pela liberdade, individualidade, bem como por experiências pessoais. Dessa forma, é ressaltada a imagem sensorial da marca, pois o consumidor busca um mercado mais diversificado (variedades) para poder assim satisfazer suas necessidades hedonísticas. Em uma situação inversa, em que em as pessoas seguem normas sociais, é reforçada a questão da afiliação, ou ainda, de ser membro/ fazer parte de um grupo. Nesse sentido, é ressaltada a imagem social da marca de um certo bem de consumo.

No que diz respeito às características sócio-econômicas regionais, o seu estudo é de relevada importância para a identificação de similaridades ou diferenças intra e inter países. Nesse sentido, em muitos paises, as regiões existentes podem-se diferenciar mercadologicamente em função de características como renda, mobilidade, acesso à mídia, empregabilidade, entre outros. Assim, conforme as descobertas obtidas por estudiosos da área e apresentadas por Roth (1995), pode-se dizer que:

- de modo geral, a exposição do consumidor aos canais de comunicação exerce um efeito favorável sobre o grau de consumo;

- a existência de uma renda elevada leva o indivíduo a buscar a satisfação de sensações sensoriais e hedonísticas (imagem sensorial da marca) e, por outro lado, uma renda baixa conduz ao preenchimento de necessidades básicas, ressaltando assim, a imagem funcional da marca de um produto;

- a imagem social da marca é ressaltada quando o consumidor é exposto a um aumento de material cultural, que o motiva a procurar a aquisição de produtos associados a essas outras culturas e sociedades. Esse comportamento estimula a modernização de mercados regionais e, ao mesmo tempo, encoraja o indivíduo a valorizar mais o aspecto da auto-consciência.

Na maioria dos paises, a correlação existente entre renda per capita e modernidade é bem alta. A mensuração do fator mobilidade associado à exposição do indivíduo a sociedades com diferentes níveis de modernidade, demonstrou que ambos podem afetar o grau de consumo de uma sociedade, mais especificamente, de uma região.

Tomando-se por base a Figura 2.2.2.3, concluí-se que a caracterização de mercados estrangeiros é um forte indicador para a segmentação e identificação de mercados potenciais e, consequentemente, desempenha, também, o papel de um instrumento para a mensuração do "market share" do produto. O estudo mais aprofundado das regiões inseridas em uma sociedade pode estreitar o conhecimento quanto às questões de heterogeneidade/ homogeneidade, bem como identificar a ênfase atribuída à imagem da marca, dependendo do grau em que o consumidor é exposto aos meios de comunicação (mídia). 
No que diz respeito ao fator levantamento e interpretação dos dados obtidos, Chapman (1992) apud Tayeb (1994) ressalta a existência de uma forte ligação entre a abrangência do conceito atribuída ao termo cultura, bem como entre o estudo dos aspectos organizacionais escolhidos pelo pesquisador. Com relação à primeira consideração, o autor mencionado verificou em seus estudos que, quando a cultura é considerada uma entidade que engloba uma série de construtos sociais (normas, crenças, valores, pensamentos, sentimentos e comportamentos), a cultura de fato influencia o item gerenciamento, pois este último está inserido nos limites da sua abrangência. Se o espectro do termo cultura for definido como não tendo nenhuma relação com os apectos econômicos, políticos, legais, religiosos, educativos, tecnológicos entre outros, será esperada uma atenuada influência. A segunda consideração está relacionada com a identificação de dimensões (centralização da tomada de decisão, especificação de papéis e funções, padronização e procedimentos e formalização) que defininem a visível estrutura organizacional, bem como com as atitudes ligadas às relações de poder e autoridade, relacionamentos, incertezas e riscos, confiança, lealdade e comprometimentos, motivação, controle e disciplina, coordenação e integração, comunicação, troca de experiências e participação. Essas atitudes são representadas por procedimentos e ações com amplo significado local e interno, muitas vezes invisíveis.

Com base nas assertivas mencionadas anteriormente, pode-se dizer que aqui termina a universalidade das organizações. A estrutura das organizações é similar, o significado é diferente, pois este último depende de características sócio-culturais. Assim, constata-se que a forma como as pessoas se relacionam (atitudes e valores) está fortemente associada com fatores enraizados em cada sociedade e ligados à educação, ocupação e à origem social. Portanto, o pesquisador deve basear-se nessa reflexão antes de estruturar o seu estudo. E, ao desenhar a sua pesquisa, esta deve ter o seu escopo voltado para as dimensões (estrutura) e atitudes (procedimentos e ações para alcançar as dimensões).

Outro ponto bastante importante a ser considerado, é a questão denominada conflito ético. Situações de conflito são classificadas como tendo a origem centralizada na facilidade ou não de adaptar-se ao novo e obter um consenso entre os valores (centrais e periféricos) envolvidos, a influência (poder ou não de limitar opiniões) exercida pelo tomador de decisão, bem como saber em que condições (rapidez ou lentidão) a decisão ocorre. Os principais tipos de conflito ético dizem respeito à má interpretação nas ações e no comportamento (por exemplo, o significado do ato de se presentear em uma sociedade) do indivíduo e à conceitualização do que é certo e ético (Kohls e Buller, 1994).

Dessa forma, o pesquisador precisa alargar os seus conhecimentos e tornar-se mais familiar acerca da cultura local em que o estudo estiver se desenvolvendo. A troca de dilemas éticos pode ocorrer quando ambas as partes diferirem fortemente quantos aos valores centrais e se houver significativa influência de poder por parte de ambos os lados (confrontação aberta), ou ainda, quando for empregada a estratégia da intervenção/ mediação para resolver diferenças de valores. A adaptação aos padrões da cultura local abrange os seguintes aspectos: 
- não ofe.1_..: : sensibilidade para construir uma relação efetiva de trabalho;

- identificar o conceito denominado de relativismo cultural, ou seja, padrões que determinam o que é certo ou errado;

- procurar manter um equilibrio entre os padrões/ valores já adquiridos com os que estão sendo vivenciados durante a realização do estudo.

Khols e Buller (1994) destacam ainda que, em um ambiente em que haja troca de cultura, as estratégias utilizadas para resolver conflitos éticos são:

- esquivar-se em tomar uma decisão: escolha frequentemente empregada quando os custos da persuasão no conflito forem elevados;

- poder: frequentemente usado quando uma das partes é mais forte do que a outra;

- persuasão: é um mecanismo que busca convencer outras pessoas a adotarem a sua opinião, por intermédio do uso de informações, da razão, ou ainda, através do apelo emocional;

- infiltração: introduzir deliberadamente ou intencionalmente os seus valores em uma outra sociedade. Como exemplo, citam-se os valores associados às questões de liberdade e consumerismo;

- negociação: ambas as partes envolvidas desistem de alguma coisa para estabelecerem/ negociarem um acordo, que nem sempre pode ser vantajoso para os dois lados;

- acomodação: é quando uma das partes, simplesmente, adapta-se à ética do outro;

- colaboração para a resolução de um problema: as duas partes trabalham juntas para alcançar uma solução vantajosa para ambos, resultado, também, conhecido como ganha-ganha.

Para cada uma das estratégias relacionadas acima, há ocasiões apropriadas. Em geral, os fatores mais amplamente aplicados e que podem influenciar a tomada de decisão são:

- estágio de desenvolvimento moral do tomador de decisão;

* estrutura ética específica usada no processo de decisão;

- expectativas individuais e valores relacionados aos resultados com a decisão a ser tomada;

- certos fatores contextuais e padrões que regem o comportamento dos indivíduos, tais como: cultura corporativa, leis nacionais e internacionais, tarifas alfandegárias entre outros.

A seguir, serão apresentados alguns estudos que identificaram a influência da linguagem contida nas embalagens de alimentos sobre o comportamento de compra do consumidor. 
2.2.2.4. A estrutura de preferência de atributos e o conteúdo informativo das embalagens de alimentos

O campo de estudo sobre o comportamento do consumidor ainda é relativamente novo. Entretanto, a partir do conhecimento das características gerais do mercado de consumo, torna-se possível identificar e analisar como se dá a dinâmica do comportamento do consumidor e, mais especificamente, como está organizado o seu comportamento de compra.

Para compreendermos melhor como se dá a organização do comportamento de compra do consumidor, torna-se relevante conhecer o mecanismo empregado pelo usuário em busca da satisfação de suas necessidades e desejos. Nesse sentido, Kotler (1990b) destaca cinco modelos determinantes das necessidades e motivações humanas, os quais auxiliam a identificar o que realmente os consumidores estão procurando em suas aquisições de bens e serviços, além de estarem diretamente relacionados ao desejo de aquisição do produto. A seguir, relacionam-se os modelos de motivação a saber:

- modelo de aprendizagem: a necessidade do homem pode ser interpretada por meio da interação de impulsos, estímulos, sugestões, reações e reforços. Os impulsos podem ser classificados como impulsos primários (fome, sede, dor) e aprendidos (medo, culpa, orgulho). Estes últimos, são aprendidos por intermédio da experiência em procurar satisfazer os impulsos primários. Um impulso vem a ser um forte estímulo interno que impulsiona o indivíduo à ação. Quando um impulso estiver dirigido para um objeto específico, tem-se um motivo. Esses objetos tornam-se estímulos no momento em que são capazes de exercitar e satisfazer os impulsos. Os estímulos menores, aqueles que determinam quando, onde e como as pessoas reagem são denominados sugestões. A resposta do organismo à configuração do estímulo e das sugestões representa uma reação. Uma reação pode ser compensadora, transformando-se no reforço da sugestão. Caso a reação não seja compensadora, provavelmente haverá uma diminuição da reação e, consequentemente, um enfraquecimento das reações aprendidas em virtude da falta do seu exercício prático, bem como da de reforço.

- modelo psicoanalítico: este modelo mostra que as necessidades do homem são trabalhadas em vários níveis de consciência não facilmente observáveis. Sua identificação requer a utilização de método especial de sondagem. $O$ comportamento humano não é simples. Portanto, é difícil identificar, bem como compreeender as fontes motivadoras do homem. Nesse sentido, pode-se dizer que o consumidor é motivado tanto por aspectos simbólicos como funcionais. Como exemplo, Kotler (1990b) comenta que donas-de-casa poderão apresentar um sentimento de culpa, proveniente da sensação de vida fácil, em decorrência de uma propaganda sobre mistura para bolo, que afirma, praticamente, não envolver qualquer trabalho no seu preparo. As técnicas de projeção, associação de palavras, interpretação de gravuras e a de representação de um papel podem abrir a guarda dos egos individuais e fornecer indícios para as motivações humanas mais profundas.

- modelo sociológico: este modelo reconhece que as necessidades e o comportamento humano são fortemente moldados pelos grupos e forças sociais. Pode-se dizer que a cultura é a fundamental determinante dos desejos de uma pessoa. A adaptação ao meio ambiente e o auxílo prestado à sociedade decorrem do estabelecimento de um padrão de percepções, valores e comportamentos. A cultura está estreitamente relacionada com a maneira como os indivíduos vêem, pensam e sentem. Inseridas no processo de socialização, encontram-se as 
subculturas e cada uma delas proporciona maior identificação específica para os membros constituintes desses grupos menores. Outro aspecto a ser considerado no modelo sociológico é a estratificação social ou classe social. As classes sociais representam divisões com certa homogeneidade e estabilidade em uma sociedade. A ordenação de cada uma dessas divisões ocorre em função dos mesmos valores, estilos de vida, interesses e comportamento compartilhados pelos seus membros integrantes. Dentre as características das classes sociais, destacam-se o comportamento semelhante, a posição hierárquica (posições inferiores e superiores) ocupada pelas pessoas, a classificação indicada por variáveis sócio-econômicas (renda, fortuna, grau de instrução, profissão, orientação de valor, entre outras), bem como o seu caráter contínuo (não discreto), isto é, o indivíduo pode migrar tanto de uma classe social mais alta para uma mais baixa ou o seu inverso. $O$ entendimento acerca desta variável social permite identificar e atingir públicos-alvo específicos, os quais também divergem em seus processos de decisões de compra. Neste modelo, encontram-se pequenos grupos chamados grupos de referência (familia, amigos, associações profissionais etc), que também exercem influência sobre o indivíduo. Para algumas categorias de produtos e marcas os grupos de referência afetam de maneira significativa o comportamento de consumo. Assim, pode-se dizer que quanto maior a coesão do grupo de referência, mais eficaz será o processo de comunicação e quanto maior for a estima do indivíduo pelo grupo, maior será sua influência ao determinar a escolha por um produto e marca.

Conclui-se, portanto, que o aprendizado social exerce forte influência sobre as motivações básicas do indivíduo. E, para interpretar os fatores e objetivos que levam o consumidor a se sentir motivado por um produto e marca, é preciso um profundo conhecimento acerca dos sistemas de normas e de valor em uma cultura, subcultura, classe social, bem como nos grupos de referência.

- modelo econômico: este modelo baseia-se no princípio da utilidade marginal decrescente, ou seja, à medida que o consumidor adquire unidades adicionais de um determinado produto, estas proporcionarão uma satisfação decrescente. A busca e o processamento adequados pela informação sobre um dado produto permitirão que o consumidor aplique com eficácia a sua renda na aquisição de um certo número de unidades, que irá conferir ao usuário a maior utilidade total. A partir do modelo econômico, constata-se, de modo geral, que: produtos com preço mais baixo, têm a sua venda elevada; produtos substitutos com baixo preço, apresentam uma venda baixa; quando a renda for alta, maior será o volume de venda desse produto $e$, finalmente, altas despesas com comunicações, sugerem ser alto o número de vendas.

- modelo da hierarquia das necessidades: segundo Maslow (1954) apud Kotler (1990b), existem cinco necessidades básicas que estão dispostas em uma hierarquia de importância. $O$ Quadro 2.2.2.4, esboçado a seguir, apresenta a hierarquia de necessidade de Maslow. 
Quadro 2.2.2.4 A hierarquia de necessidade de Maslow

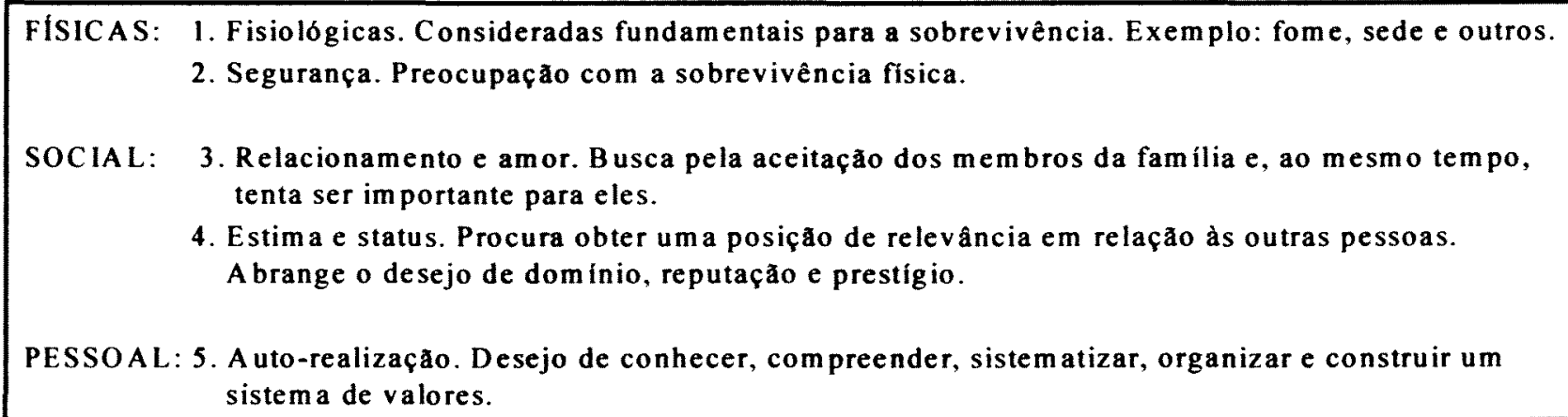

Fonte: Kotler P. Marketing: edição compacta. São Paulo: Atlas; 1990b. p. 110.

A partir da apresentação esquematizada anteriormente, observa-se que as necessidades são categorizadas em fisicas, sociais e próprias e, sobretudo, mantém-se em uma ordem hierárquica de importância. À medida que as necessidades de números mais baixos vão sendo satisfeitas, as necessidades subsequentes tomam o seu lugar. Por exemplo, um indivíduo faminto (necessidade 1), talvez não venha a interessar-se pelas últimas novidades do mundo artístico (necessidade 5). Dessa forma, a estrutura de Maslow é uma estrutura útil, por intermédio da qual pode-se identificar as possíveis necessidades que o consumidor queira satisfazer ao adquirir um produto, bem como explicar as mudanças ocorridas acerca das necessidades ao longo do tempo.

Quanto à organização do comportamento de compra do consumidor, é relevante fazer a identifcação da unidade de tomada de decisão. Esta última pode ser formada por um indivíduo ou por um grupo de indivíduos, que compartilham de objetivos e/ou objetivos comuns, buscam alcançar esses objetivos, bem como dividem os riscos decorrentes da decisão tomada (Kotler, 1990b). Além disso, é preciso identificar o papel ou papéis que a pessoa está desempenhando ao representar uma unidade de tomada de decisão. Os cinco papéis existentes são mencionados a seguir:

- iniciador: é o papel desempenhado pela pessoa que, em primeiro lugar, sugeriu ou teve a idéia de comprar um certo produto.

- influenciador: vem a ser a pessoa que, explícita ou implicitamente, exerce influência sobre a decisão final a ser tomada.

- decisor: é aquele que decide, parcial ou totalmente, a compra. Isto é, compra-se ou não, o que comprar, como comprar, quando comprar e onde comprar.

- comprador: é a pessoa que efetivamente realiza o ato da compra.

- usuário: vem a ser a pessoa que usa ou consome o produto/ serviço adquirido.

Outro importante aspecto a ser considerado na organização do comportamento de compra do consumidor vem a ser as caracteristicas familiares. Nesse sentido, cabe destacar a questão relativa à localização da autoridade da família. Herbst (1954) apud Kotler (1990b) identificou a familia 
autônoma (número igual de decisões separadas é tomado pelos integrantes), a dos tipos dominância do marido e dominância da esposa e aquela denominada sincrética (decisões tomadas em conjunto). Atualmente, o modelo sincrético vem se destacando sobre os demais, o que traz importantes implicações na definição dos objetivos do profissional da área de marketing. Dentro, ainda, das características familiares encontram-se os antecedentes culturais e de classe social (variaç̃̃es na especialização das tarefas dos membros das familias nos grupos étnicos), bem como o estágio do ciclo de vida da familia (solteiro, recém-casado).

Neste momento, as reflexões estarão voltadas para o consumidor, ou seja como ele realiza as suas aquisições de bens e serviços e, sobretudo, que fatores estão presentes no processo e influenciam a sua tomada de decisão. O comportamento de compra pode ser interpretado como uma atividade para a solução de problemas. Assim, o número e a complexidade das operações realizadas pelo consumidor variam em função do tipo de produto a ser aquirido (Howard, 1974 apud Kotler, 1990b). De modo geral, o consumidor pode vivenciar três tipos de situação de compra. A primeira situação está relacionada a operações rotineiras (comportamento de reação rotineira), ou seja, refere-se à aquisição frequente de determinados produtos. Nesse caso, o comprador dispõe de informações sobre a classe do produto, tem consciência acerca das marcas mais importantes e dos atributos do produto, bem como tem estabelecida uma escala de preferência bem definida em relação ao item marca. A segunda situação de compra (solução de problemas limitados) é mais complexa e ocorre quando o consumidor se encontra diante de marca desconhecida, para uma classe de produto familiar. Nessa situação o consumidor tem consciência da classe de produto e das qualidades que deseja. Porém, precisa de alguma informação antes de tomar a sua decisão, pois não está familiarizado com todos os conceitos de marca. A terceira e última situação de compra (solução de problemas amplos) apresenta uma complexidade maior. $\mathrm{O}$ consumidor está diante de uma classe de produto desconhecida e não dispõe de critérios claros (conceitos de marca, atributos de classe do produto) para empregar na tomada de decisão.

Independentemente do tipo de situação relativa à aquisição de um produto, a estrutura de decisão de compra representa um conjunto de decisões ordenadas sobre a categoria do produto, a marca, o vendedor, quantidade, tempo, ou ainda, quanto às condições de pagamento. A tomada de decisão pela aquisição de um produto começa muito antes do ato propriamente dito da compra $\mathrm{e}$ acarreta consequências por um bom tempo decorrido. Em linhas gerais, por intermédio de um modelo sobre o processo de tomada de decisão, as explicações fornecidas pelo comportamento (como variáveis e circunstâncias se alteram) podem ser percebidas visualmente, a estrutura de referência auxilia a identificar lacunas no conhecimento e no entendimento dos fatos, bem como ajuda a definir prioridades da pesquisa e, finalmente, obtem-se a fundamentação dos acontecimentos com o gerenciamento dos sistemas de informação disponíveis. De acordo com Kotler (1995) e Engel, Blackwell e Miniard (1995a), o processo de tomada de decisão é constituído por cinco estágios como demonstram os esquemas das Figuras 2.2.2.4a e 2.2.2.4b. 
Figura 2.2.2.4a Estágios do processo de compra

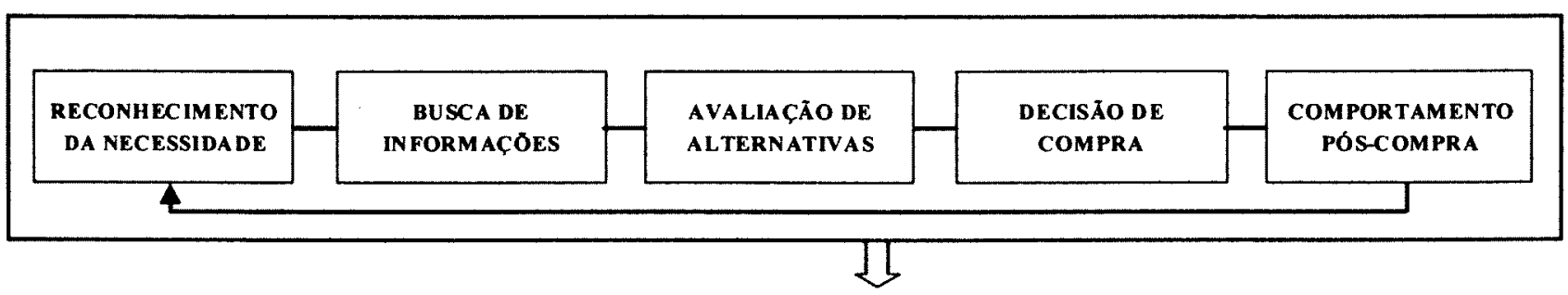

Fonte: Kotler P. Administração de marketing: análise, planejamento, implementação e controle. $3^{\text {a }}$ ed. São Paulo: Atlas; 1995. p. 227.

Figura 2.2.2.4b Processo de tomada de decisão do consumidor

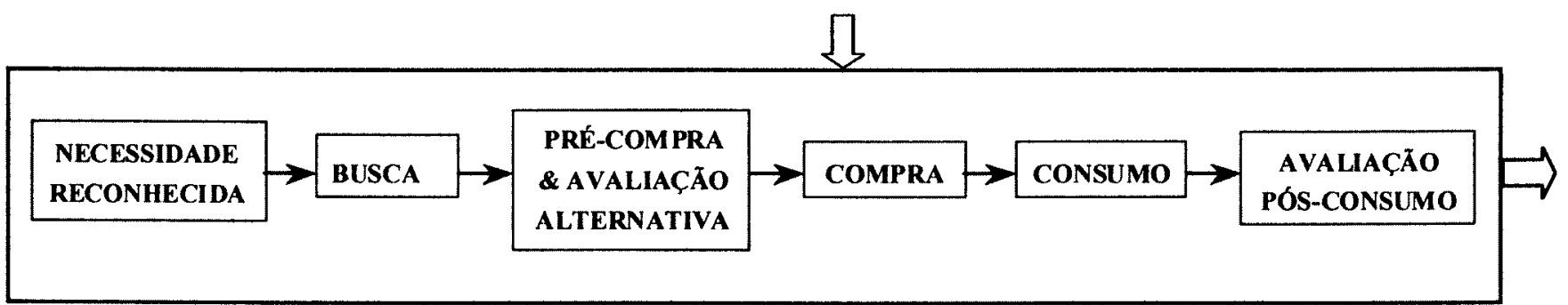

Fonte: Engel JF, Blackwell RD, and Miniard PW. Consumer Behavior. $8^{\text {th }}$ ed. Chicago: The Dryden Press; 1995a. p. 137-74.

Segundo os autores já mencionados e tomando-se por base os modelos esboçados anteriormente, far-se-á uma descrição sobre cada um dos estágios presentes no processo de decisão e empregados pelo consumidor.

A. Reconhecimento da necessidade - o início do processo de compra é caracterizado pelo despertar da necessidade, ou seja, um estímulo interno (fome, sede) ou externo (rótulo da embalagem, propaganda sobre um produto na televisão) pode ativar o aparecimento de uma necessidade. Com o passar do tempo, a intensidade atribuída à necessidade despertada poderá aumentar ou diminuir, dependendo do surgimento ou não de preocupações mais prementes a serem resolvidas naquele dado momento. Como demonstra a Figura 2.2.2.4c, o estágio de desejo, que inicia o processo de decisão, ocorre por intermédio da interação de três elementos determinantes: a informação armazenada na memória do consumidor, as diferenças individuais (valores e necessidades) e as influências ambientais, em especial as interações sociais. 
Figura 2.2.2.4c Determinantes para o reconhecimento da necessidade

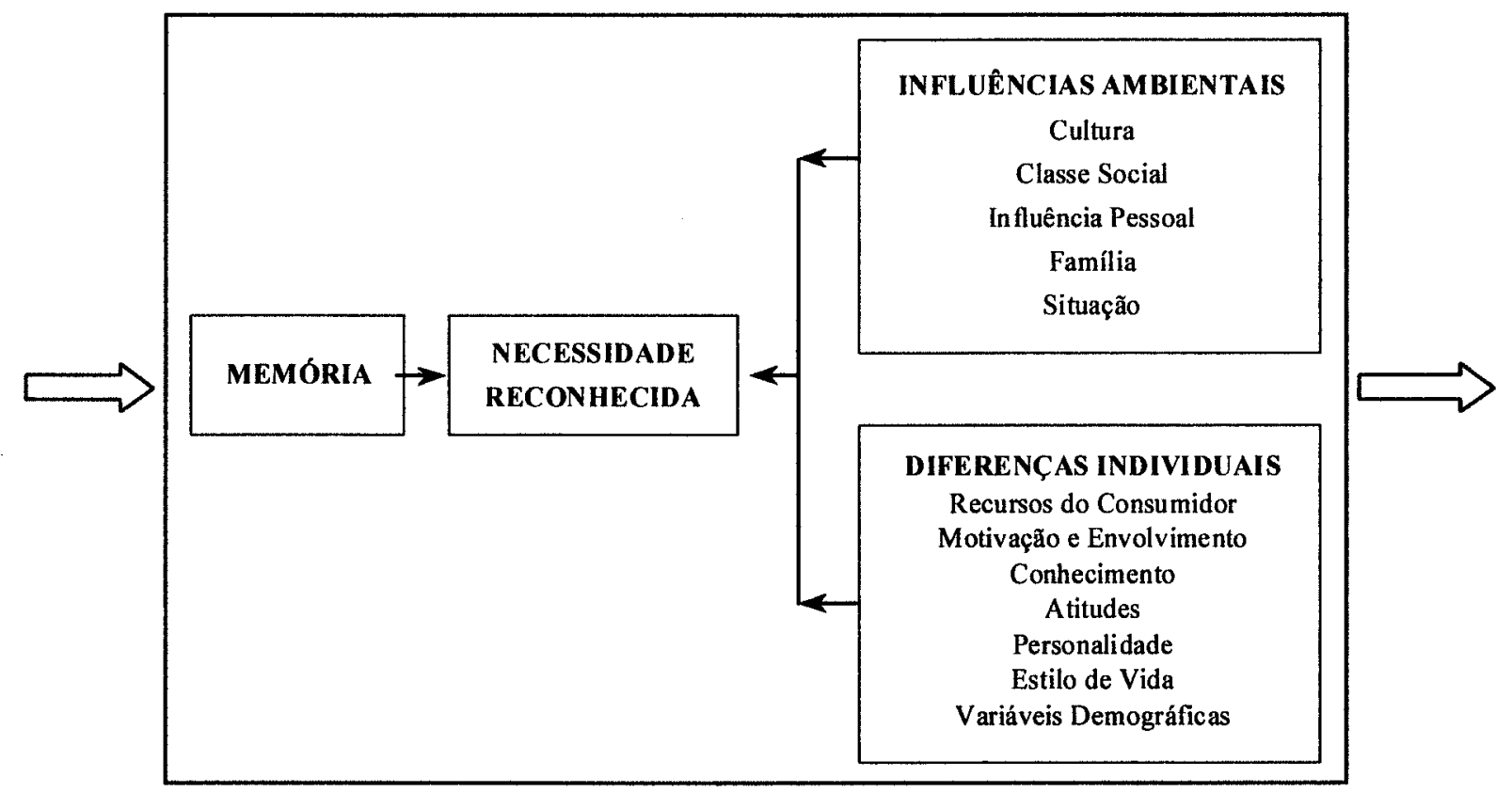

Fonte: Engel JF, Blackwell RD, and Miniard PW. Consumer Behavior. $8^{\text {th }}$ ed. Chicago: The Dryden Press; 1995a. p. 148.

Antes de uma necessidade ser reconhecida é preciso que ela, em primeiro lugar, seja ativada. Nesse estágio, fatores relacionados a mudanças circunstanciais na vida do indivíduo, como por exemplo o nascimento de um bebê, pode desencadear novas necessidades (alimentação, mobiliário, vestuário). $\mathrm{O}$ fator aquisição de um produto (compra de uma casa) poderá gerar $\mathrm{o}$ desejo (a vontade) em adquirir outros (itens para decorar o imóvel) bens de consumo. $\mathrm{O}$ ato de estar consumindo um produto (por exemplo, as últimas fatias de pão de forma), pode despertar uma necessidade antecipada, ou seja, a compra futura de um outro pacote do referido produto. Influências do marketing (por exemplo propaganda de uma marca, de uma companhia de seguro de saúde) podem funcionar como um estímulo e, assim, tornar consciente certas necessidades latentes do consumidor. Quanto às diferenças individuais, pode-se dizer que o desempenho de um produto em seu estado atual pode conduzir o consumidor a reconhecer, por exemplo, a necessidade pela compra de uma nova peça do vestuário, caso esta não esteja mais satisfazendoo. Por outro lado, a situação denominada estado desejado do indivíduo, o reconhecimento da necessidade é representado como um resultado de seus desejos por algo novo a ser adquirido. Nesse sentido, o diagrama esboçado na Figura 2.2.2.4c' ilustra o que acontece desde a ativação até o reconhecimento da necessidade. $O$ reconhecimento da necessidade depende do grau de discrepância (distância) existente entre o estado atual (situação corrente) e o estado desejado (vir a ser) do consumidor. 
Figura 2.2.2.4c' O processo de reconhecimento da necessidade

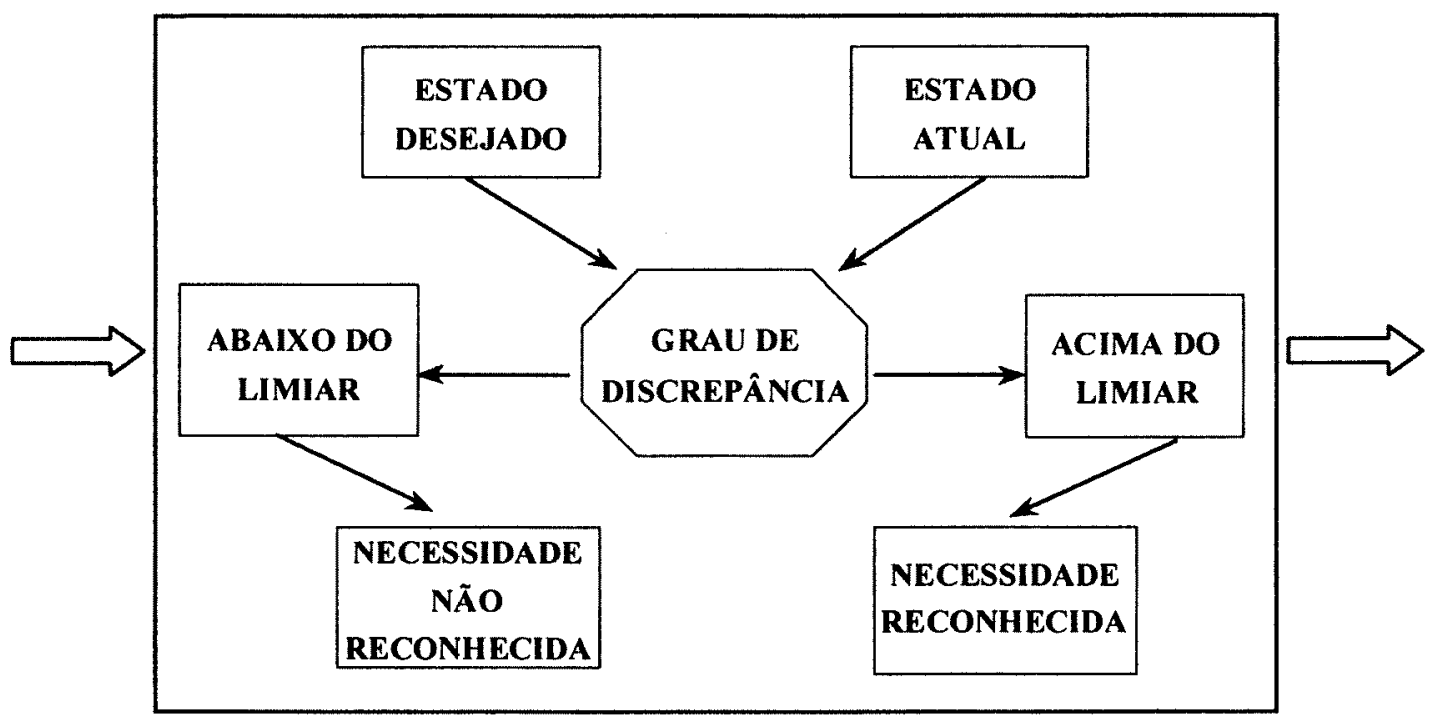

Fonte: Engel JF, Blackwell RD, and Miniard PW. Consumer Behavior. $8^{\text {th }}$ ed. Chicago: The Dryden Press; 1995b. p. 177.

B. Busca de informações - uma necessidade nem sempre é imediatamente satisfeita. $O$ indivíduo pode não ter atribuído significativa intensidade à necessidade despertada, ter definido claramente o objeto a ser adquirido, ou ainda, não ter este último à sua disponibilidade. Caso a necessidade gere uma significativa intensidade, $o$ indivíduo passará para o estado de ativa procura por informações. $\mathrm{O}$ volume de informações a ser levantado está diretamente relacionado com o tipo de solução do problema (limitado ou amplo). Normalmente, as fontes de informações do consumidor integram os grupos de fontes pessoais (família, amigos, entre outros); comerciais (embalagens, propagandas); públicas (organizações de proteção ao consumidor, mídia), bem como aquelas relativas a experiências (uso do produto, manuseio) já vivenciadas pelo consumidor. Cada tipo de fonte exerce uma função e pode, até, influenciar a tomada decisão. Informações oriundas de fontes pessoais exercem uma função legitimadora ou avaliativa e as de origem comercial representam uma função informativa. A escolha por uma dessas fontes de informações irá depender da categoria do produto a ser adquirido, bem como das características pessoais (por exemplo, condições financeiras) do consumidor. As Figuras 2.2.2.4d e 2.2.2.4d' mostram esquematicamente as considerações apresentadas e, sobretudo, ressalta como o processo pode ser afetado pela busca externa de informações, pelas diferenças individuais, bem como pelas influências ambientais. 
Figura 2.2.2.4d Processo de busca interna de informação

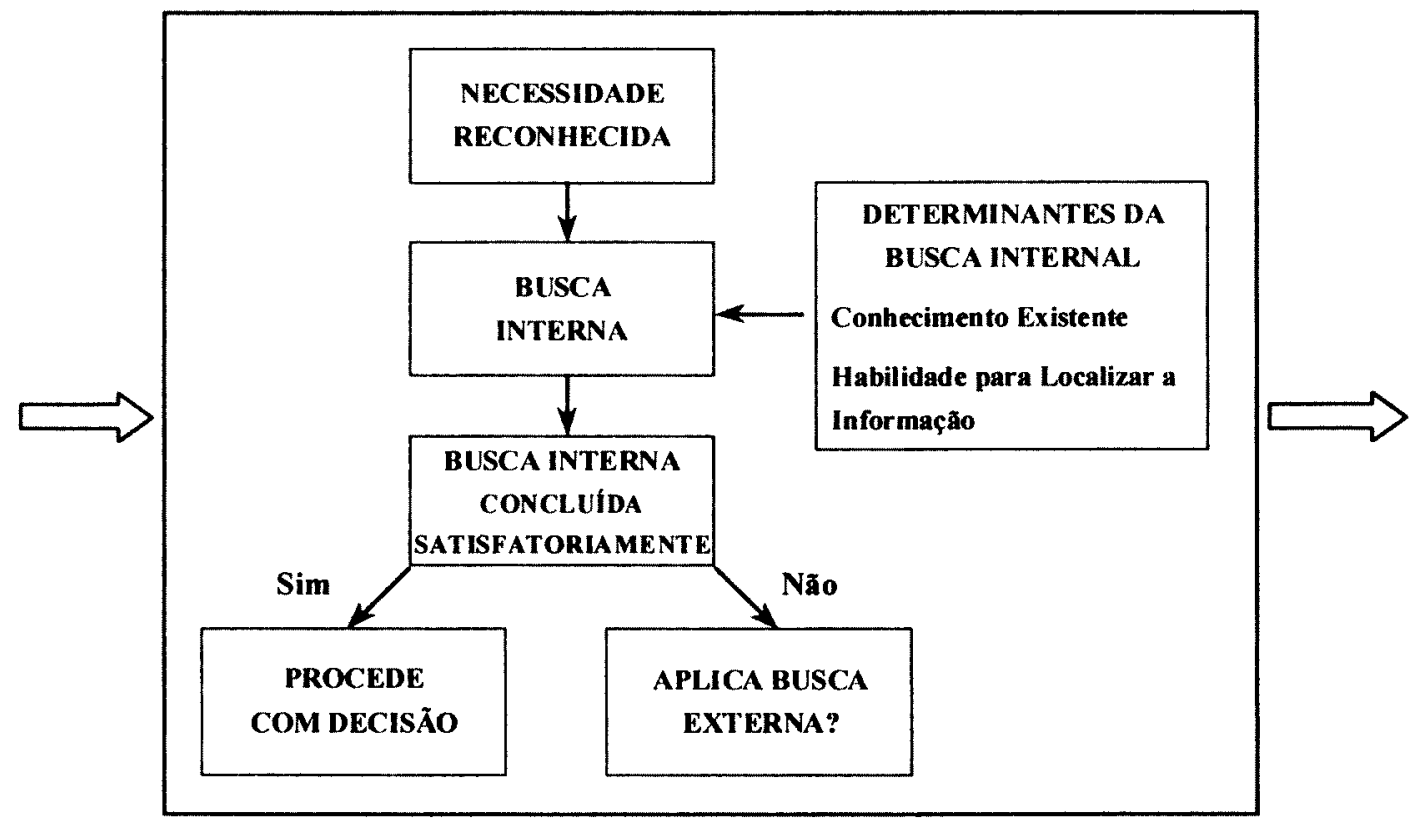

Fonte: Engel JF, Blackwell RD, and Miniard PW. Consumer Behavior. $8^{\text {th }}$ ed. Chicago: The Dryden Press; 1995b. p. 184.

Figura 2.2.2.4d' Busca de informação no modelo de tomada de decisão

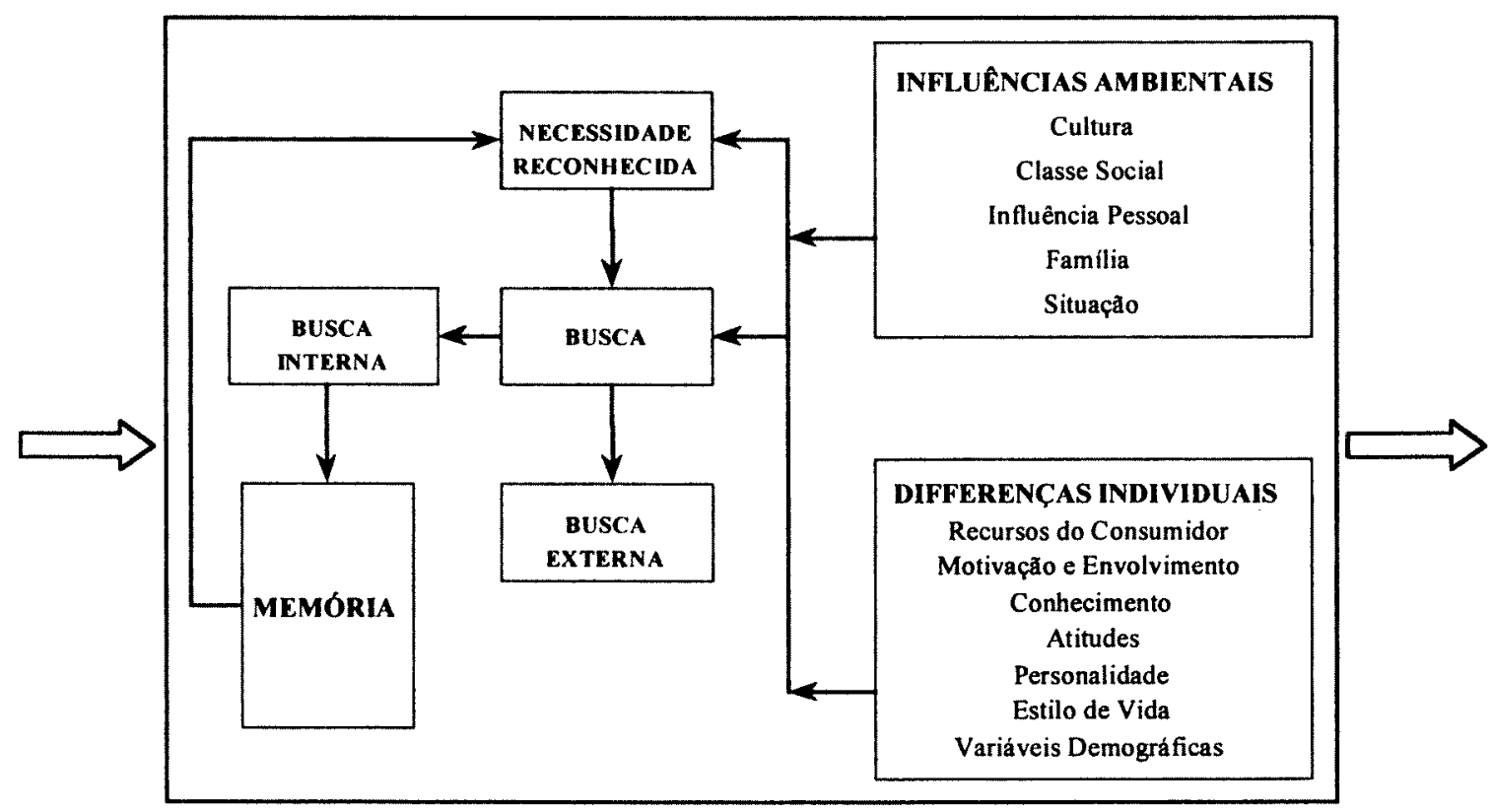

Fonte: Engel JF, Blackwell RD, and Miniard PW. Consumer Behavior. $8^{\text {th }}$ ed. Chicago: The Dryden Press; 1995a. p. 149. 
C. Avaliação de alternativas - neste estágio, ocorre o processamento das informações levantadas que levam o consumidor a manifestar suas atitudes e intenções acerca do bem de consumo. O mecanismo é complexo e envolve alguns conceitos básicos que auxiliam na compreensão dos processos de avaliação dos consumidores. $\mathrm{O}$ conceito atributos do produto refere-se ao conjunto de propriedades peculiares de uma determinada classe de produtos. Por exemplo, na categoria de laticínios, alguns dos atributos do iogurte são tipo, finalidade, consistência, sabor, entre outros. Por intermédio do conceito imagem de marca o consumidor avalia (com base em suas percep̧̧ões, experiências vividas) o desempenho da marca para cada um dos atributos elencados. A função utilidade descreve como o consumidor deseja ter a sua satisfação preenchida. Por exemplo, a satisfação de um consumidor pode aumentar de acordo com o preço promocional em relação ao número de frascos de iogurte em uma embalagem e pode diminuir ao perceber que o prazo de validade do produto será esgotado antes de ele consumir todas as unidades. Finalmente, o conceito denominado procedimento de avaliação ou regra de decisão representa um conjunto ordenado de atitudes (julgamento e preferências) do consumidor em relação aos vários atributos de determinado produto (Engel, Blackwell e Miniard, 1995c). A forma como o consumidor pode elaborar uma escala de preferência de bens pode ser explicada por intermédio de pelos menos seis modelos, descritos a seguir:

- modelo de predominância ou de determinação: um atributo pode ser importante para o consumidor, mas quando a sua presença for predominante em todos os produtos que estiverem sendo avaliados, deixará de exercer influência na escolha do bem de consumo. Por exemplo, um consumidor pode valorizar bastante a velocidade do computador, porém, se todos os computadores forem igualmente rápidos, talvez o indivíduo não se decida por nenhum. Quando um produto estiver em paridade nos atributos importantes, a escolha poderá ser determinada por intermédio dos atributos menos importantes. Portanto, verificase que o consumidor leva em consideração tanto os atributos determinantes como os considerados mais importantes.

- modelo conjuntivo: normalmente, o consumidor para tomar a sua decisão por um determinado produto estabelece um conjunto de requisitos mínimos que o produto deve possuir. Isso quer dizer que elevar o nivel de um atributo não compensa o baixo desempenho ou a ausência de outro atributo. Por exemplo, para um consumidor de iogurte "pronto para beber" os requisitos mínimos poderiam ser prazo de validade, sabor, unidade de consumo, marca e preço. $O$ consumidor poderá não adquirir nenhuma marca do produto, caso ele esteja sendo ofertado por um preço promocional, se o item sabor não preencher suas necessidades pessoais de preferência.

- modelo disjuntivo: neste modelo, o critério empregado pelo consumidor baseia-se no produto que apresente o atributo desejável e cujo desempenho seja melhor em relação aos demais. O consumidor não adota um mecanismo compensatório, ou seja, mesmo que outras variáveis apresentem uma boa pontuação, não preencherão a expectativa e necessidade do consumidor em relação ao desempenho do atributo especificado a priori. Para exemplificar, considerar-se-á, ainda, o iogurte "pronto para beber". O consumidor poderá privilegiar apenas os produtos que excedam os niveis para o item prazo de validade (tempo maior de duração), independentemente de sua posição em relação aos demais atributos especificados por ele.

- modelo lexicográfico: é caracterizado pela ordenação dos atributos em grau de importância. A marca que apresentar a sequência de atributos hierarquizados pelo 
consumidor configurará a sua escolha. Cabe ressaltar que o processo deste modelo também não é compensatório. Assim, tomando-se por base os requisitos mínimos considerados para um consumidor de iogurte "pronto para beber", a ordenação de sua preferência poderia levar em consideração prazo de validade, sabor, marca preço e unidade de consumo. Dentre as marcas ofertadas, o consumidor se definirá por uma única marca, ou seja, aquela que ofereça o melhor prazo de validade para consumo do produto.

- modelo expectativa-valor ou valor-esperado: normalmente, os consumidores selecionam um conjunto de atributos importantes e atribuem notas (pesos) a cada um deles, bem como à imagem das marcas selecionadas. $O$ resultado dessa operação constitui o modelo de valor esperado, isto é, a atitude global do consumidor em relação a cada marca. Neste caso, acredita-se que níveis de atributos possuídos por uma marca sejam compensatórios.

- modelo de ponto ou marca ideal: o processo empregado representa uma variação do modelo anterior. Em primeiro lugar, o consumidor concebe em sua mente a imagem da marca ideal. Posteriormente, ele estabelece uma comparação entre as marcas atuais e a considerada ideal. Nesse sentido, a marca que mais se destacar no processo de avaliação terá a preferência do consumidor.

Levando-se em consideração o esquema da Figura 2.2.2.4e, cabe, também, ressaltar que em um estilo de compra, o primeiro passo é a exposição do consumidor à comunicação da informação, a qual desencadeará o processo como um todo. No passo seguinte, a atenção do consumidor é impactada caso a informação recebida seja relevante para ele. Em seguida, o consumidor busca em sua memória subsídios para analisar, compreender, aceitar e reter a mensagem recém incorporada ao processo. Tomando-se por base a apresentação dos referidos modelos, observa-se serem diversas as formas pelas quais o consumidor pode estabelecer suas preferências por produtos. Torna-se, portanto, importante identificar, no mercado, os principais estilos de compra. A partir desse conhecimento será possível aprimorar o processo para decodificar necessidades e desejos do consumidor e, consequentemente, estreitar a comunicação entre os agentes de produção e consumo. Entender o comportamento decisório do comprador no processo de compra significa identificar os pontos críticos do processo, para poder atuar de forma a minimizar os hiatos existentes na comunicação entre os agentes de produção e consumo e, assim, auxiliar o consumidor a fazer a sua escolha de forma objetiva e segura.

D. Decisão de compra - a aquisição de um dado produto abrange decisões relacionadas às indagações de efetuar ou não o ato de compra, quando comprar, o que comprar, onde comprar e, ainda, como comprar. Para tomar uma decisão, o consumidor estabelece um conjunto de preferências a partir de uma série de produtos alternativos ofertados pelo mercado. Este estágio é caracterizado pela presença do sentimento (ou atitude) que conduz o consumidor à situação denominada intenção de compra. A intenção de compra por um dado produto, por sua vez, é moldada pelos fatores sociais, bem como pelos fatores situacionais antecipado e não previsto. Os fatores sociais estão relacionados à fonte geradora de informação, que pode externar uma atitude reprovadora (negativa) ou favorável (positiva) acerca do produto analisado pelo comprador. Quando o consumidor apresentar um estreito relacionamento em relação à fonte fornecedora de informação, ele se sentirá mais motivado em rever a sua intenção de compra com base nos sentimentos externados por essa fonte. Nesse sentido, uma atitude negativa por parte do fornecedor da informação poderá levar o consumidor a avaliar negativamente a sua intenção de 
compra. O fator situacional antecipado contribui para a formação da intenção de compra a partir de elementos conhecidos pelo consumidor como renda, termos estabelecidos pelo revendedor, disponibilidade esperada do produto, entre outros. Os fatores situacionais não previstos ocorrem entre a formação da intenção de compra e o ato da compra propriamente dito. Esses fatores estão relacionados à ocorrência de oscilações na economia, no campo profissional (demissão, contratação), ou ainda, a disponibilidade ou não do produto no mercado (Engel, Blackwell $\mathrm{e}$ Miniard, 1995d). Verifica-se, dessa forma, que uma intenção de compra poderá não resultar em uma compra efetiva, pois o consumidor é fortemente influenciado pela situação denominada risco percebido. A representação da Figura 2.2.2.4f ressalta os aspectos ligados à ampliação e avaliação da informação coletada. Além disso, observa-se, também, uma interação a partir do relacionamento estabelecido entre os atores presentes no processo e as estratégias de persuasão empregadas.

Figura 2.2.2.4e A avaliação da informação no modelo de tomada de decisão

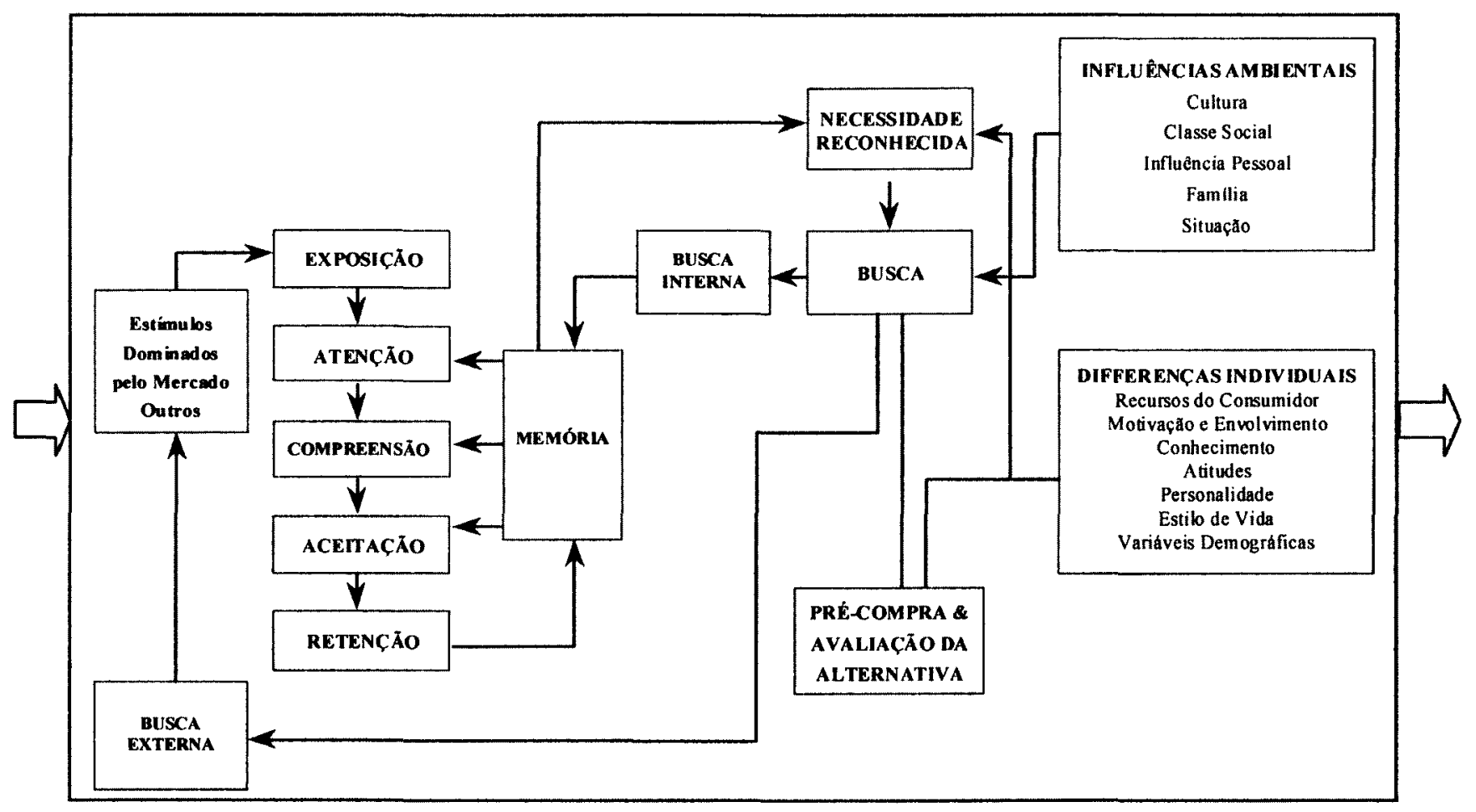

Fonte: Engel JF, Blackwell RD, and Miniard PW. Consumer Behavior. $8^{\text {th }}$ ed. Chicago: The Dryden Press; 1995a. p. 151. 
Figura 2.2.2.4f A compra no modelo de tomada de decisão

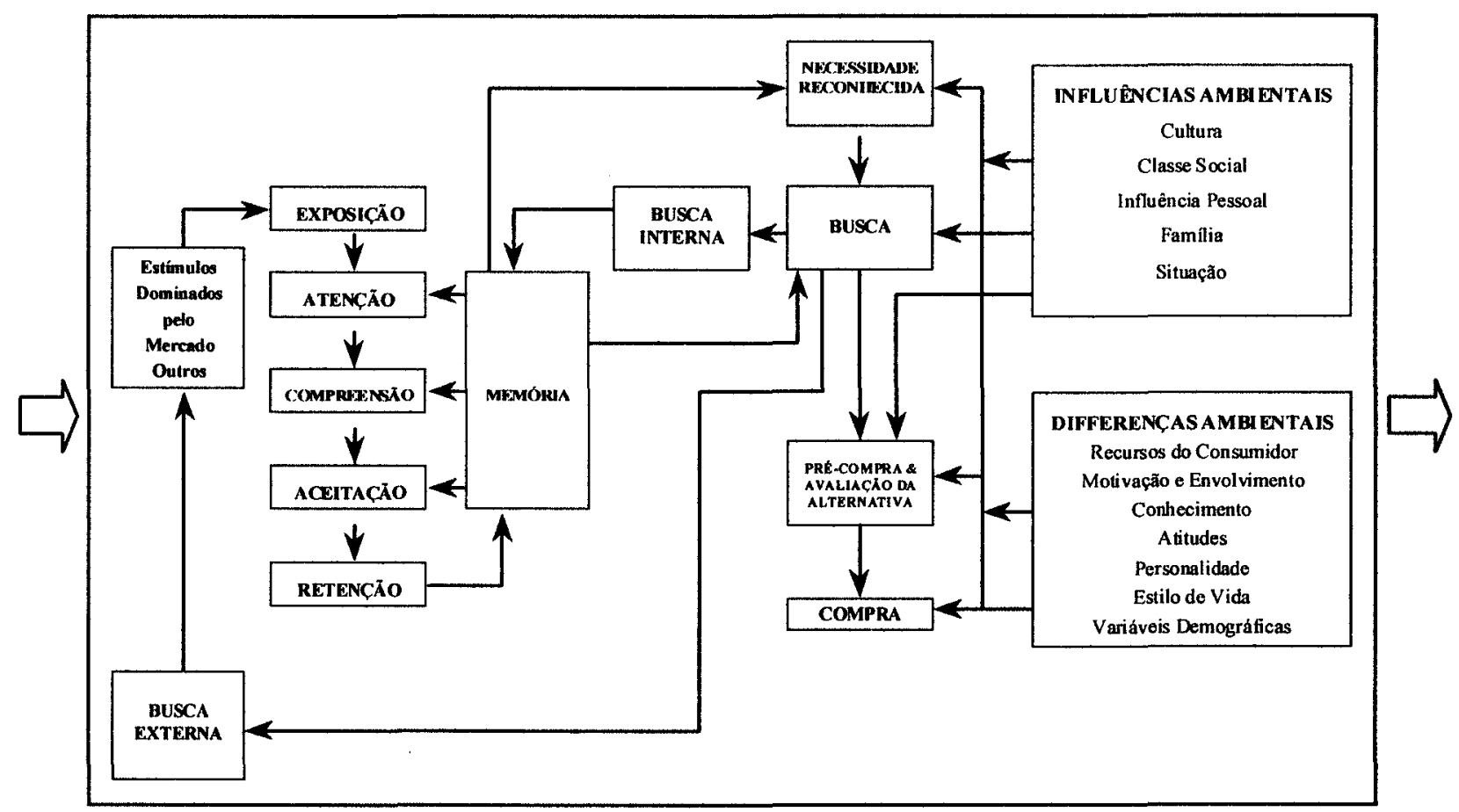

Fonte: Engel JF, Blackwell RD, and Miniard PW. Consumer Behavior. $8^{\text {th }}$ ed. Chicago: The Dryden Press; 1995a. p. 152.

E. Comportamento pós-compra - estão relacionadas com o grau de satisfação ou insatisfação que o consumidor teve em relação à sua última compra de um dado produto. Se o consumidor ficar insatisfeito com o produto adquirido, ele fará uma revisão negativa acerca das suas atitudes em relação ao produto, podendo, até, descartá-lo da lista de opções alternativas em compras futuras. $O$ surgimento de um sentimento caracterizado pela falta de harmonia entre a percepção do consumidor em relação ao produto adquirido e as opções rejeitadas, por ele, gera a chamada dissonância cognitiva. De modo geral, o consumidor procura reduzir essa dissonância. Tenta devolver ou vender o produto, ou ainda, levantar informações que elevem a superioridade do produto adquirido. Caso o consumidor fique satisfeito com a compra efetuada, essa experiência vivenciada poderá reforçar sua preferência pela marca adquirida e, consequentemente, levar a uma situação de recompra do produto (Engel, Blackwell e Miniard, 1995d). Nas esquematizações das Figuras 2.2.2.4g e 2.2.2.4g' observa-se, portanto, o processo completo de compra de um dado produto, com destaque para as etapas referentes ao consumo, avaliação das alternativas pós-consumo, bem como quanto ao destino (descarte) do produto após o uso. Este último envolve, portanto, aspectos ligados à distribuição completa do item, reciclagem e, consequentemente, uma revisão no plano de marketing para ofertar o produto ao mercado. 
Figura 2.2.2.4g Modelo do comportamento do consumidor

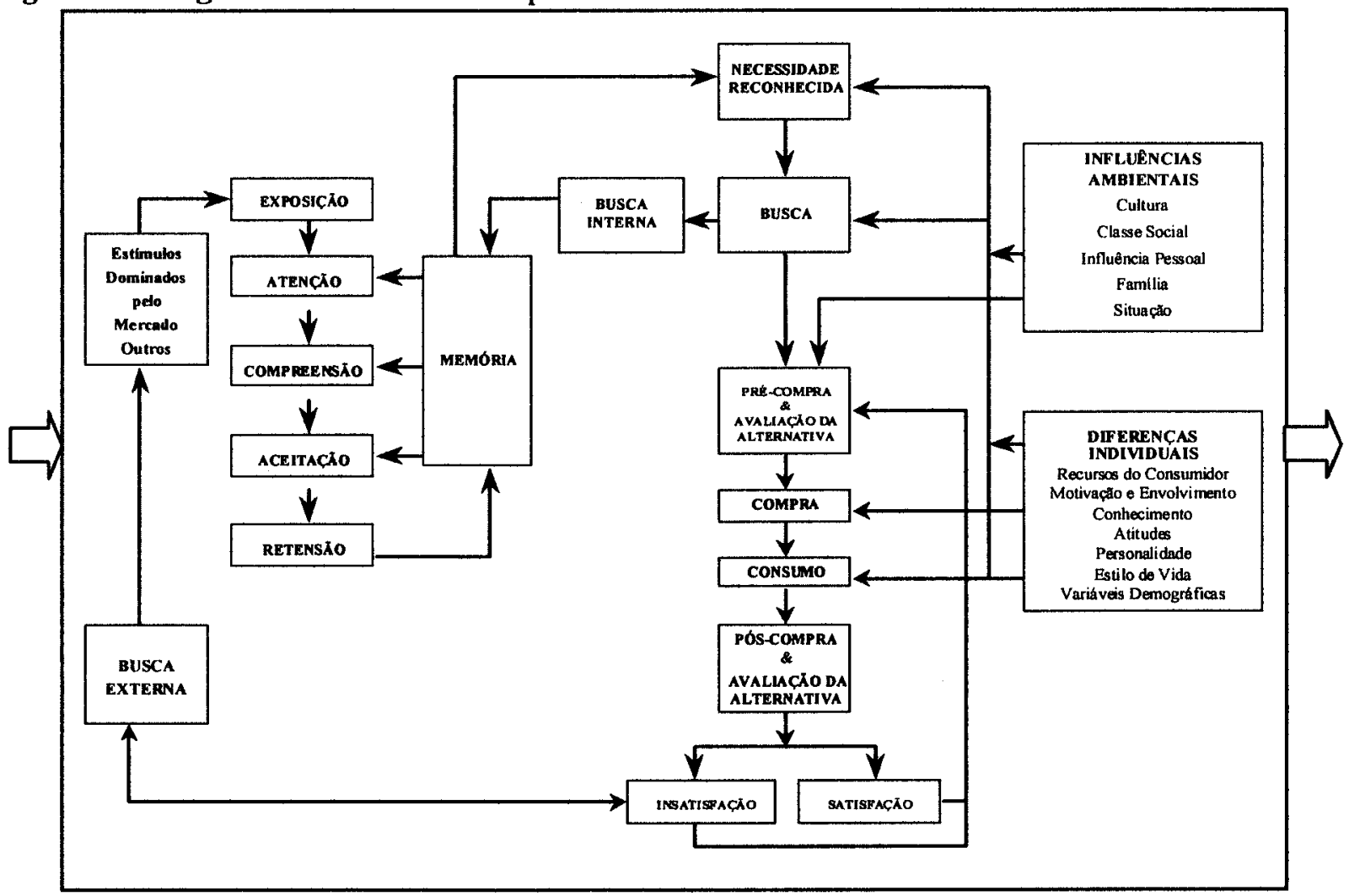

Fonte: Engel JF, Blackwell RD, and Miniard PW. Consumer Behavior. $8^{\text {th }}$ ed. Chicago: The Dryden Press; 1995a. p. 153.

Associados aos estágios do processo de compra descritos anteriormente, encontram-se variáveis denominadas exógenas que irão influenciar e atribuir um caráter particular ao comportamento individual do consumidor. Howard e Sheth (1974) apud Kotler (1990) identificaram sete variáveis exógenas, a saber:

* importância da compra: o consumidor atribuirá diferentes graus de importância à aquisição de vários produtos. O montante de informações a ser levantado, o conjunto de atributos especificado entre outros, dependerão da importância conferida pelo consumidor a um dado produto.

- traços da personalidade: justificativa pela aquisição de um bem, procedimentos de avaliação em relação à compra, ou ainda, sentimentos de satisfação/ insatisfação são influenciados pelos traços (pessoa com autoconfiança, extrovertida) da personalidade do consumidor.

- status financeiro: é medido pela renda do indivíduo. Esta irá exercer influência sobre os critérios de avaliação, o motivo da compra, tempo despendido e a quantidade a ser adquirida.

* pressão do tempo: esta variável exerce influência quanto à busca de informação, bem como quanto ao procedimento de avaliação adotado pelo consumidor. Nesse sentido, quando houver escassez de tempo para o consumidor tomar a sua decisão, o conjunto de opções será reduzido, a identificação dos atributos será restrita e, ainda, serão adotadas medidas simplificadoras nas estratégias de avaliação. 
- condições sociais e organizacionais: estas variáveis exercem influência quanto aos motivos que levam o consumidor a efetuar uma compra, sentir-se motivado por um dado produto, bem como conduz à avaliação das informações levantadas.

- classe social: os antecedentes de classe social influenciam os motivos e os processos de compra do consumidor.

- cultura: em um nível mais profundo e significativo, tanto a cultura como a subcultura influenciam as necessidades e os processos de compra do consumidor.

Figura 2.2.2.4g' Modelo completo do comportamento do consumidor: compra e resultados

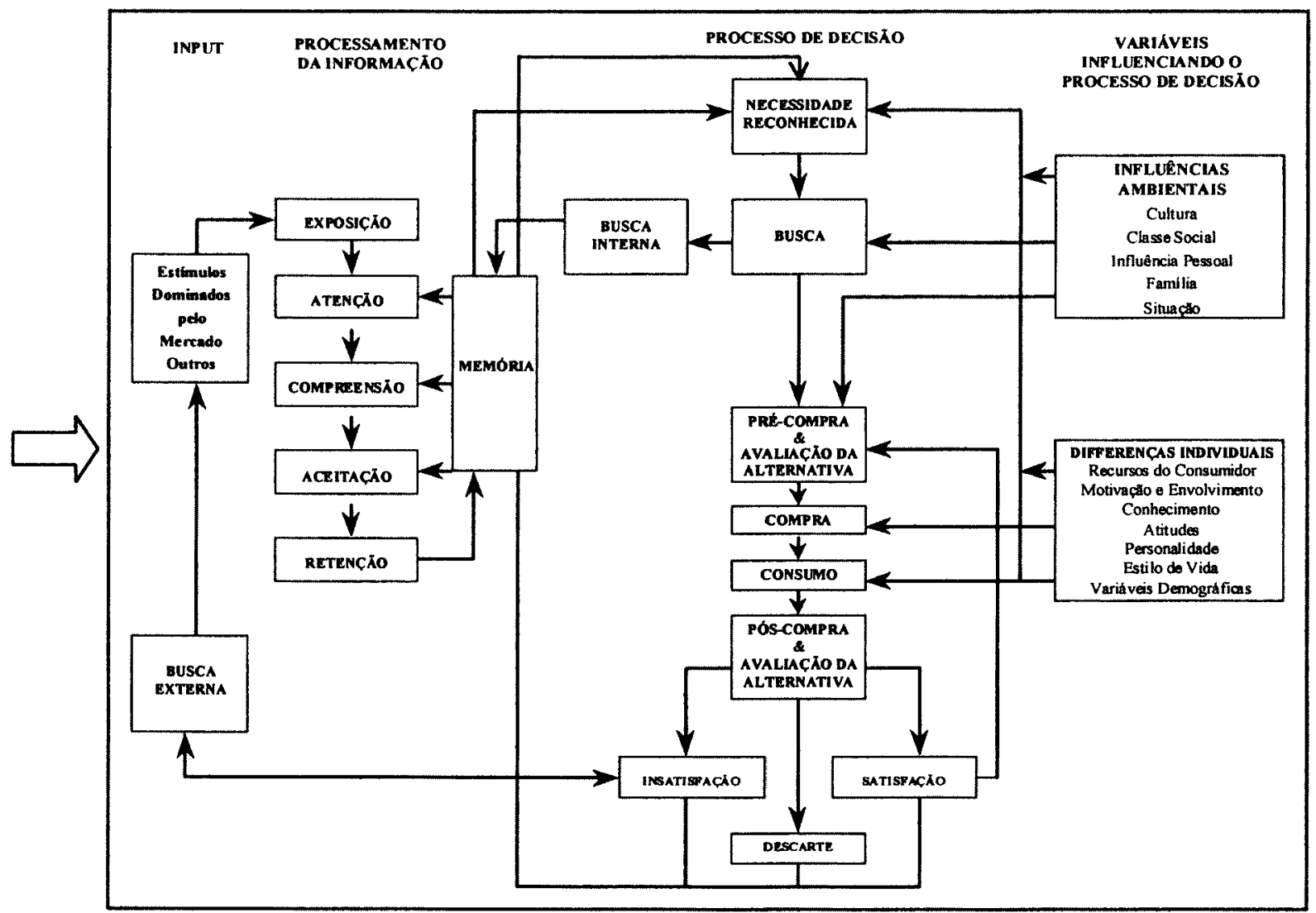

Fonte: Engel JF, Blackwell RD, and Miniard PW. Consumer Behavior. $8^{\text {th }}$ ed. Chicago: The Dryden Press; 1995a. p. 154.

Para este estudo de caráter exploratório, o conhecimento do modelo comportamental de decisão dos consumidores foi de grande valia para o entendimento do papel desempenhado pela embalagem, no processo de compra do consumidor. A utilização de um modelo não tem a capacidade de predizer o comportamento do consumidor. No entanto, representa a reunião de elementos-chave e interdisciplinares característicos das abordagens sobre o comportamento do consumidor. Em outras palavras, de que maneira características individuais, influências ambientais e processos psicológicos recebem os estímulos externos que permitem a elaboração de idéias sobre um produto, ou parte dele, no caso, a embalagem, que podem vir a se consolidar na tomada de decisão com a compra ou não desse produto. 
A realização de uma pesquisa científica do comportamento do consumidor, que procure esclarecer como ele entende o conteúdo informativo da embalagem de alimentos para uma dada categoria de bens de consumo, é de suma importância. Esse esforço pode revelar se suas necessidades, seus desejos e expectativas estão sendo atendidos e, conseqüentemente, mostrar a efetividade do processo de comunicação entre produtor e consumidor, propiciado pela embalagem de alimentos.

Durante o processo de avaliação de um produto para a sua possivel aquisição, o consumidor leva em consideração um conjunto de fatores que são determinantes para a tomada de decisão. Dentre esses fatores, destacam-se aqueles ligados ao composto de marketing, ou seja, conceito e atributos (finalidade, aplicação, praticidade, entre outros) do produto, preço, canais de distribuição e facilidade de acesso para a compra, bem como os referentes às campanhas promocionais. A combinação e ordenação desse conjunto de características simultâneas que o produto possui, pode indicar a preferência do consumidor por um determinado produto.

\subsubsection{Estudos sobre as tendências do comportamento de compra do consumidor norte- americano}

Ao longo dos anos, pesquisas realizadas por instituições norte-americanas têm verificado o surgimento de um segmento inovador no comportamento da população (Food Marketing Institute, 1988). Com a elevação da expectativa de vida média do americano, este apresenta uma visão global relativa a uma associação entre o consumo alimentar e a melhoria na qualidade de vida (Kraft e Goodell, 1993).

Os pesquisadores Turck e Goldhaber (1989) desenvolveram um estudo para avaliar como o consumidor daquele país elabora um sistema cognitivo para processar e decodificar as informações contidas nas embalagens de alimentos. Essa pesquisa mostrou que o processo compreende o emprego de um certo tempo para analisar o rótulo das embalagens e nesse momento, os conceitos de "produto seguro" e "uso seguro" do item, são elaborados com base na aquisição de conhecimento fornecida pelas informações sugeridas e recomendadas pelo veículo de comunicação.

Outro estudo (Rheinstein e Bagley, 1992), constatou que a tomada de decisão pela compra ou não de um gênero alimentício pelo consumidor norte-americano, era influenciada pelo conjunto de informações contidas na embalagem. Além disso, observou-se, também, que havia um crescente interesse pelos termos "low" (baixo), "light" (leve), "lean" (magro), "source of" (fonte de), principalmente, entre os produtos manufaturados.

Seguindo a mesma linha de estudo dos trabalhos citados anteriormente, Slabber (1993) e Miller (1994) desenvolveram pesquisas para avaliar o entendimento do consumidor norte-americano, com relação ao preenchimento das necessidades diárias e as porções de consumo indicadas nos rótulos nutricionais. Com esses estudos verificou-se que a utilização de um sistema padronizado para informar as porções de consumo, ou seja, a apresentação em grama e com seu equivalente 
em medidas caseiras, auxiliaria o consumidor a comparar os itens ofertados, bem como a compor sua dieta alimentar.

A realização dessas pesquisas mostra que, por intermédio de uma dinâmica interação entre a ciência e as exigências legais de rotulagem, as informações contidas nas embalagens de alimentos poderiam estar, constantemente, sendo atualizadas de acordo com as necessidades do mercado consumidor, além de promover a informação segura de compra e consumo do produto.

De acordo com Tollefson (1994), a inserção de descritores deve seguir uma regulamentação baseada em estudos científicos, que estabeleçam uma relação entre a ingestão de certos alimentos e o seu impacto sobre a saúde pública, em virtude das doenças denominadas doenças crônicas. A diabetes e os problemas cardiovasculares são alguns exemplos de doenças crônicas, cuja principal característica é a perpetuação do problema ao longo da vida do indivíduo.

Levy, Fein e Schucker (1996) desenvolveram um estudo com o objetivo de avaliar sete formatos de rotulagem nutricional e, assim, poder determinar o grau de compreensão e aceitação, por parte dos consumidores, acerca das informações apresentadas nas embalagens de gêneros alimentícios. Para tal, levaram em consideração a comparação dos rótulos de dois produtos, o julgamento sobre os aspectos saudáveis ressaltados nas embalagens analisadas, análise sobre as chamadas "splashes" impressas, as porções de consumo estimadas para o alcance das necessidades nutricionais diárias recomendadas, bem como o balanceamento dos nutrientes consumidos diariamente. Os autores identificaram que os consumidores preferiram os formatos com informações métricas acrescidas de um texto interpretativo. As descobertas encontradas têm um importante impacto sobre as decisões tomadas pela "Food and Drug Administration - FDA" quanto à definição do formato do rótulo nutricional.

Todos os pontos levantados nas pesquisas mencionadas anteriormente são extensivos a um público consumidor muito especial: os diabéticos. Portanto, a veracidade das informações permitiria que o consumidor fizesse um auto-gerenciamento de suas decisões, durante as etapas de compra e consumo dos gêneros alimentícios (Wheeler et al, 1994). As inúmeras pesquisas, que têm sido realizadas com os consumidores norte-americanos, mostram a complexidade do assunto em questão, bem como a preocupação por parte dos estudiosos em identificar medidas alternativas para o aprimoramento do processo de comunicação através da embalagem de alimentos.

No próximo sub-item deste capítulo serão apresentadas as tendências do comportamento de compra do consumidor brasileiro, a partir do conteúdo informativo contido no rótulo das embalagens dos gêneros alimentícios. 


\subsubsection{Estudos sobre as tendências do comportamento de compra do consumidor brasileiro}

Dos trabalhos identificados como relevantes para o assunto em questão, verificou-se que são raros os estudos desenvolvidos com o consumidor brasileiro, com vistas a identificar o seu entendimento pelas informações contidas nas embalagens de alimentos e o grau de influência que ela possa exercer nas tomadas de decisão pela compra ou não de um gênero alimentício.

A autora desenvolveu um estudo exploratório sobre a abordagem sistêmica para a embalagem de alimentos (Castro, 1994). Ficou evidenciado que o consumidor passou a estabelecer uma análise mais criteriosa sobre o conteúdo informativo inserido nos rótulos das embalagens de alimentos. Muitas vezes, a informação recebe um peso relativo, isto é, com a validade em vias de vencimento, o produto não será adquirido mesmo que o preço esteja por um valor muito favorável.

No Brasil, matéria publicada em comemoração ao terceiro aniversário de vigência do Código de Defesa do Consumidor (Senra, 1994), mostrava que era mais dificil encontrar um consumidor desatento e menos exigente, especialmente quando se tratava de gêneros alimentícios. Percebeuse que o consumidor, de maneira geral, além de buscar por informações expressas nas embalagens, recorria aos Serviços de Atendimento ao Consumidor (SAC), com o objetivo de complementá-las e/ou esclarecer dúvidas.

De acordo com outra matéria publicada (Guia de Embalagem, 1995, p. 38), verificou-se que os "itens de qualidade inferior, caros demais ou que apresentem defeito, podem representar um destino fatal para as empresas que os fabricam". Com o Código de Defesa do Consumidor, em vigor desde 1991 e a abertura do mercado doméstico, o comportamento do consumidor mudou. Ele vem sendo mais exigente ao buscar a excelência da qualidade dos produtos, pois esses dois fatos, respectivamente, permitiram que o consumidor brasileiro passasse a exercer os seus direitos de cidadania, bem como expusessem os nossos produtos e serviços à comparação com os importados.

Segundo um artigo publicado por Benzi (1994, p. 76) na revista F\&C Embalagem, constatou-se que para os consumidores de iogurtes, a embalagem, além de ser um "elemento que impulsiona a decisão de compra", deve ser um veículo que "venda a idéia" incorporada pelo seu conteúdo, ou seja, compatível com os conceitos dos atributos do produto, a serem desempenhados na ocasião de compra-consumo dos itens ofertados pelo mercado.

Após uma caracterização do comportamento de compra do consumidor, de um modo geral, o próximo item irá enfocar a relação entre qualidade e lucro. Tem-se como ponto de partida o comportamento do consumidor, como fator gerador de investimentos no veículo de comunicação denominado embalagem de alimentos. 


\subsection{Embalagem de Alimentos e o Comportamento do Consumidor: Relação entre Qualidade e Lucro}

\subsubsection{Considerações gerais}

Entre a embalagem de alimentos e o consumidor são identificados, pelo menos, dois momentos distintos de comunicação. O primeiro ocorre no ponto-de-venda, momento em que formas, cores e demais elementos gráficos permitem que o consumidor reconheça a sua marca tradicional na gôndola, tenha a sua curiosidade despertada para um produto desconhecido, assim como tome sua decisão pela aquisição ou não de um bem de consumo. O segundo momento é a constatação ou não, de que as expectativas do consumidor foram alcançadas. Essa etapa ocorre, provavelmente, com o consumidor em sua casa, ocasião em que as informações inseridas na embalagem poderão ser utilizadas para a abertura do invólucro, uso-consumo do produto, bem como uma fonte de informações para fornecer esclarecimentos complementares sobre um determinado item. Por exemplo, tem-se o caso de consumidores que entram em contato com o Serviço de Atendimento ao Consumidor (telefone, endereçamento postal), para saber o significado do termo halvarina ${ }^{5}$ existente nas embalagens dos produtos pertencentes à categoria de margarinas.

De acordo com o parecer de profissional conceituado na área de desenvolvimento de embalagens, esse veículo de comunicação pode significar "um ativo fixo da empresa, um investimento físico" (Simas, 1994, p. 215). Para isso, cada elemento gráfico da embalagem deve possuir um valor contábil, além de conferir à embalagem agregação de valor, por ocasião da união de todos esses elementos. Segundo o ponto-de-vista desse profissional, em uma entrevista concedida à revista Embanews, a embalagem é "a ferramenta de marketing que mais tempo acompanha o produto, dando-lhe identidade" (Simas, 1994, p. 62). Em certos mercados, ela é o único veículo de divulgação do produto, pois a propaganda nem sempre está presente em todas as situações de promoção de um bem de consumo.

Ainda, segundo a matéria publicada pela revista Embanews, mencionada anteriormente, Seragini, um expoente brasileiro como designer de embalagens, apresentou dados que destacaram a embalagem como uma das peças de marketing que "vende mais o produto do que a propaganda" (Seragini, 1994, p. 62). Por exemplo, segundo ele, no Brasil, dos 10 mil produtos comercializados nos supermercados, apenas $1 \%$ conta com o apoio da propaganda o ano inteiro. Além desse aspecto, o designer ressaltou que " $70 \%$ da decisão de compra é tomada na prateleira (comparação de marcas, atratividade da embalagem, informações do conteúdo e preço)" (Seragini, 1994, p. 62). Dessa forma, ele conclui que a embalagem é "o maior veículo de propaganda que um produto pode ter" (Seragini, 1994, p. 62).

Levando-se em consideração as assertivas mencionadas anteriormente, pode-se dizer que a embalagem é um instrumento que permite mensurar a satisfação do consumidor e a participação do produto no mercado e com isso, identificar a relação entre qualidade e lucro existente nesse

\footnotetext{
${ }^{5}$ Halvarina: Termo utilizado para designar uma classe de produtos pertencente à categoria de margarinas. Sua denominação está relacionada com o teor de gordura existente (aproxidamente $40 \%$ ), em relação àquele contido no produto considerado convencional. Esta explicação é fruto do conhecimento prático da pesquisadora.
} 
importante veículo de comunicação entre os agentes produtor e consumidor. No tópico seguinte, por intermédio da embalagem, mais especificamente, a de alimentos, será feita uma abordagem conceitual, que procurará demonstrar os beneficios da utilização de um programa para medir o retorno do investimento em qualidade, aplicado a esse poderoso instrumento de marketing.

\subsubsection{Abordagem conceitual de um programa de avaliação de investimento em qualidade}

Cabe ressaltar que os princípios básicos da abordagem conceitual do programa de avaliação do impacto financeiro de uma empresa, apresentados neste tópico do trabalho, estarão subsidiados no estudo desenvolvido por especialistas norte-americanos (Rust, Zahorik e Keiningham, 1995) ao mensurar o retorno sobre a qualidade.

O objetivo central de um programa de avaliação, que visa a medir o retorno do investimento em qualidade, é estabelecer e/ou manter a ligação, bem como a satisfação entre cliente/ consumidor ${ }^{6}$ e a participação de mercado de um bem de consumo.

De acordo com os autores mencionados anteriormente desse conceito, para alcançar esse objetivo, é preciso que a empresa tenha respostas claras para as seguintes indagações imprescindíveis:

- qual é a ligação existente entre o cliente/ consumidor e o mercado e como estabelecê-la na empresa?;

- quais são, exatamente, as exigências ou necessidades do cliente/ consumidor?;

- o cliente/ consumidor estará disposto a "pagar" por essa exigência?.

A empresa precisa, portanto, voltar-se para o mercado e estreitar sua comunicação com o cliente/ consumidor. As necessidades e os desejos dos usuários tornam-se cada vez mais complexos e o seu atendimento não deixa de ser um grande desafio às empresas preocupadas em ofertar produtos e serviços com valor agregado. A satisfação (ganhos totais) percebida e recebida com a utilização efetiva do bem e/ou serviço adquirido é entendida como valor pelo cliente/ consumidor (Santos, 1997).

\footnotetext{
${ }^{6}$ Cliente: Termo empregado para pessoas escolhidas pela empresa, cuja tarefa mais importante desta última, é determinar quais são as necessidades, desejos e valores de um conjunto de clientes e adaptar toda a empresa para proporcionar a satisfação dos desejos. Kotler P. Marketing - edição compacta. São Paulo: Atlas; 1990a. p. 47.

Consumidor: Toda pessoa física ou jurídica que adquire ou utiliza produto ou serviço como destinatário final. Equipara-se a consumidor a coletividade de pessoas, ainda que indetermináveis, que haja intervindo nas relaçóes de consumo. BRASIL. Leis, etc. Código de Defesa do Consumidor - Lei n $^{\circ}$ 8078, de 11 de setembro de 1990: dispõe sobre a proteção de consumidor e dá outras providências. Secretaria de Defesa do Consumidor, São Paulo, 1991.p.11.
} 
Tendo conhecimento das condições que regem um negócio de parceria entre empresa e cliente/ consumidor, será possível estabelecer uma vantagem competitiva forte e sustentável de mercado. Assim, com a implantação de um programa de avaliação, em especial para a embalagem de alimentos, $o$ atendimento ao item satisfação pode ser alcançado através da evidência científica de uma relação entre qualidade e lucro.

No próximo sub-item, serão apresentados os principais pontos de um programa de avaliação de investimento em qualidade e sua aplicação para um item de consumo - a embalagem de alimentos, que representa o elo de ligação entre a satisfação dos agentes produtor-cliente-consumidor.

\subsubsection{Um programa de avaliação de investimento em qualidade e a embalagem de alimentos}

2.3.3.1. Programa de avaliação de investimento em qualidade

O sucesso de um programa de avaliação de investimento em qualidade é vinculá-lo aos resultados finais do processo, ou seja, obter redução de custos e/ou aumento da receita. Para alcançar esse objetivo, é preciso considerar todos os aspectos pertencentes a uma cadeia central de eventos, tais como: desempenho do serviço/ produto 7 , satisfação do cliente/ consumidor, retenção dos clientes/ consumidores, participação de mercado (demanda, posicionamento do produto) e, consequentemente, os lucros (Rust, Zahorik e Keiningham, 1995).

É relevante ressaltar que, em um programa de avaliação de investimento em qualidade, o processo é constituído:

- pelo próprio produto físico, ou seja, a reunião de todos os componentes envolvidos na sua configuração;

- pelo produto do serviço, isto é, o planejamento de um trabalho mais a entrega do mesmo ao cliente/ consumidor;

- pelo ambiente ou área do serviço, que é composto pelos elementos que envolvem, dão forma fisica e facilitam a entrega do serviço/ produto e, finalmente;

- pela entrega do serviço, que representa a concretização do processo.

O trabalho é complexo e necessita de um sistema abrangente de informações, para mensurar o impacto da qualidade sobre os lucros, cujo principal efeito será o de obter menores custos, em virtude da eficiência; reter mais clientes/ consumidores; atrair mais novos clientes/ consumidores, bem como potencial para oferecer melhores produtos ao mercado. Dessa forma, constata-se que a qualidade pode ser quantificada, segundo os critérios financeiros.

\footnotetext{
${ }^{7}$ Serviço: Qualquer atividade fornecida no mercado de consumo, mediante remuneração, inclusive as de natureza bancária, financeira, de crédito e securitária, salvo as decorrentes das relaçóes de caráter trabalhista. BRASIL. Lei $n^{\circ} 8078$, de 11 de setembro de 1990: dispõe sobre a proteção do consumidor e dá outras providências. Secretaria de Defesa do Consumidor [do Governo do Estado de São Paulo], São Paulo, 1991. p.11.

Produto: A existência de necessidades, desejos humanos, leva ao conceito de produto. Ou seja, produto é tudo aquilo capaz de satisfazer a um desejo. Kotler P. Marketing - edição compacta. São Paulo: Atlas; 1990a. p. 31.
} 
Dentre os fatores preponderantes de um programa de avaliação de investimento em qualidade, cabe destacar os conceitos para os seguintes termos: "atributos básicos", "atributos articulados" e "atributos excitantes" (Rust, Zahorik e Keiningham, 1995). Para facilitar o entendimento da conceituação dos termos em questão, serão citados exemplos pertinentes a cada um deles. São eles:

- "Atributos básicos": estão implícitos, mesmo que não mencionados pelo cliente/ consumidor, na oferta de um serviço/ produto. Uma empresa que não considere esses atributos, "não pode permanecer no mercado". Um exemplo, é o caso do atributo "inviolabilidade" de uma embalagem de alimentos.

- "Atributos articulados": são aqueles que o cliente/ consumidor cita como desejáveis e determinantes na tomada de decisão. $O$ bom desempenho desses atributos levará à satisfação do cliente. Como exemplo, pode ser mencionada a presença do "prazo de validade" de um gênero perecível.

- "Atributos excitantes": são atributos que encantariam e/ou surpreenderiam o cliente/ consumidor. É dificil a identificação desses atributos, porém, a sua presença é a chave para conquistar uma "forte lealdade". Um exemplo a ser citado, é o caso da empresa que toma a iniciativa de retirar do mercado o seu produto e comunicar o fato publicamente, caso este apresente algum defeito de fabricação.

Após a obtenção de informações que contemplem todos os aspectos mencionados anteriormente, deverá ser aplicado o instrumento de diagnóstico, para bem avaliar/ mensurar os componenteschave do serviço/ produto e, consequentemente, seus efeitos sobre o resultado final do processo os lucros.

Concluindo, o princípio básico da gestão da qualidade deve concentrar-se na "percepção da qualidade", ou seja, conhecer e compreender a psicologia da satisfação. Isso ocorre quando é empregado um método sistemático para identificar e analisar os fatores relacionados à expectativa (reconhecimento da qualidade percebida e esperada) ${ }^{8}$ e assim avaliar o valor atribuído ao serviço/ produto ofertado, os quais conduzem à compra-recompra do mesmo.

A seguir, será discutida a possibilidade de se aplicar um programa de avaliação de investimento em qualidade, tomando-se por base um poderoso instrumento de marketing - a embalagem de alimentos, durante o processo de comunicação e comercialização de gêneros alimentícios.

\footnotetext{
${ }^{8}$ Qualidade percebida e esperada: Termos empregados para caracterizar o intervalo de tempo existente, que prevê a satisfação do consumidor, isto é, o cliente/consumidor utiliza sua percepção acerca do serviço/ produto oferecido para tomar sua decisão pela compra-recompra do mesmo. Rust RT, Zahorik AJ, Keiningham TL. Mensurando o impacto financeiro da sua empresa: questões para qualidade. Rio de Janeiro: Qualitymark; 1995. p.45-57.
} 
2.3.3.2. A embalagem de alimentos e um programa de avaliação de investimento em qualidade

O VI Congresso Brasileiro de Embalagens, promovido pela Associação Brasileira de Embalagem - $\mathrm{ABE}$, apresentou a embalagem segundo uma visão empresarial. É uma abordagem que integra a embalagem ao inventário da empresa, destaca a sua participação como um dos componentes na composição do preço de um item, ressalta a sua função ao promover a venda de um bem de consumo, assim como mostra a sua influência sobre a obtenção dos lucros. Pode-se dizer que a embalagem vem a ser um elemento chave para estabelecer uma vantagem competitiva de mercado (Seragini, 1994).

A seguir, considerando a abordagem do profissional citado anteriormente, serão mencionados os fatores que precisam ser, plenamente explorados pela empresa e que reforçam a participação da embalagem na consolidação de um produto no mercado de consumo. São eles:

- rever os procedimentos aplicados à embalagem, de tal forma, que seja adotado um trabalho organizado e científico, para obter o potencial máximo desse instrumento de venda. A adoção de um estudo prévio e sistemático evita que a embalagem se torne um ponto fraco da empresa, em virtude da necessidade de grandes investimentos relativos à fabricação e dos ciclos de vida dos produtos, cada vez menores;

- reconhecer que a embalagem está envolvida com diversas áreas internas e externas à empresa, valorizar o fluxo de informações existente, bem como promover a sua centralização, para obter o sucesso da operação e, consequentemente, um bom resultado final. Neste item, cabe mencionar a abordagem sistêmica (Castro, 1994) desenvolvida para a embalagem de alimentos. Nesse estudo, ficou evidenciado que esse veículo de comunicação além de expressar os atributos nutritivos do alimento, sintetiza um conjunto de ações encadeadas, relativo ao complexo processo de sua produção-comercialização;

- a embalagem representa um sistema complexo. Portanto, o emprego de uma visão futura sobre o assunto, bem como a adoção de decisões estratégicas poderão contribuir para a definição do desenvolvimento de uma embalagem, ao considerar alguns parâmetros e restrições tais como: "oferta e procura de material, custos/ economia, investimentos, energia, proteção ao consumidor, meio ambiente, legislação, tecnologia/ novos materiais e processos, novos hábitos de compra, competição acirrada, novos sistemas de distribuição e comercialização, globalização, importação/ exportação..." (Seragini, 1994, p. 193);

* inserir a embalagem em um planejamento estratégico e conquistar as vantagens de: poder tomar decisões mais acertadas, identificar elementos-chave para futuras mudanças, obter vantagem mercadológica com o elemento inovação-diferenciação, melhor direcionar o esforço voltado para pesquisa e desenvolvimento, assim como o de tomar conhecimento, antecipado, de ameaças para o bom andamento dos negócios;

- e, finalmente, reconhecer que a embalagem reflete uma tecnologia, não sendo resolvida, apenas, com bom senso. 
Dando continuidade a essa linha de raciocínio, o presente estudo procura enquadrar a embalagem de alimentos dentro de um enfoque voltado para o aperfeiçoamento da estrutura interna de uma empresa, bem assim para a mensuração do investimento em qualidade aplicado a esse elo de ligação entre os agentes produtor-consumidor.

Com base no conceito, que apresenta a "Qualidade como sendo um fator que reflete o quanto um serviço/ produto atende ou supera as expectativas do cliente/ consumidor" (Rust, Zahorik e Keiningham, 1995, p. 43), foi estruturado o processo de um programa de avaliação específico para a embalagem de alimentos. Para tal, foram identificados e discriminados todos os atributos acerca da embalagem de alimentos. A disposição organizada desses atributos pode permitir a mensuração do investimento em qualidade.

Cabe ressaltar que a apresentação da listagem organizada de atributos, mencionada a seguir, sobre a embalagem de alimentos passa a constituir a proposta da pesquisadora, no sentido de poder avaliar os benefícios advindos com o aprimoramento desse veículo de comunicação. Os elementos constituintes da lista de atributos estão fundamentados cientificamente e expressam o parecer de profissionais especializados em desenvolvimento de embalagens, conforme as conclusões obtidas pela autora (Castro, 1994), em pesquisa anterior, sobre uma abordagem sistêmica para esse veículo de comunicação.

\section{Lista Organizada de Atributos sobre a Embalagem de Alimentos}

A - Produto Físico: assegurar a interdependência de todos os profissionais envolvidos no processo, sejam eles internos ou externos à empresa. É a constatação da existência de uma interação entre a voz do cliente/ consumidor e a engenharia, ou seja, a integração entre os profissionais de marketing e os da produção do binômio produto/ embalagem. Com base na utilização de um programa de avaliação de investimento em qualidade, torna-se imprescindivel relacionar os aspectos envolvidos na estruturação do "produto físico". São eles:

- pesquisar sobre o entendimento do consumidor quanto à estrutura da embalagem de alimentos. As respostas levantadas indicarão se a embalagem está desempenhando adequadamente ou não as suas funções (preservar, promover, informar), para atender as necessidades e expectativas do consumidor;

- definir com precisão os conceitos que envolvam os atributos do produto, em consonância com as necessidades e percepções do segmento de mercado escolhido;

- escolher o tipo da embalagem, em função do produto a ser desenvolvido;

- empregar material e processo de fabricação que atendam aos preceitos tecnológicos, às especificações legais (meio-ambiente, segurança) e à economia de mercado;

- prever novas tendências de mercado para recomendar o desenvolvimento de embalagens alternativas. 
A manutenção do fluxo sistematizado de informações contribui para garantir o nível de qualidade do processo, além de contribuir para a diminuição de perdas e desperdícios e, consequentemente, para a redução de custos da embalagem de alimentos.

B - Estruturação da Embalagem de Alimentos: Nesta etapa do processo, estão presentes todas as fases inseridas no planejamento, execução, produção, controle e apresentação do produto final - a embalagem de alimentos. É o momento em que deve estar claro para a empresa quais são as reais necessidades do consumidor (elaborar uma lista de atributos segundo a ótica do consumidor). Nessa lista, devem ser considerados:

- conceito do produto: deve atender aos novos hábitos de consumo (culto à forma, cultura, etnia) e preocupações com a saúde pública (consumo do alimento e a relação entre doenças, como por exemplo, cardiovasculares, diabetes, hipertensão), bem como considerar a opinião dos usuários-líderes ${ }^{9}$ (antecipação de uma demanda em formação, segmentação de mercado);

- segurança da embalagem: preservação das características organolépticas ${ }^{10}$ do produto em toda a cadeia de armazenagem, transporte, distribuição e comercialização do gênero alimentício;

- conceito de alimento seguro: ou seja, o consumidor espera contar com informações precisas que descrevam a composição e aplicação-finalidade do produto, para o seu caso em particular;

- inserção de informações: deve estar ao alcance do entendimento do consumidor, permitindo uma avaliação comparativa entre vários itens da mesma categoria, bem como sua utilidade prática (composição de uma alimentação considerada adequada) no seu dia-a-dia;

- oferecimento de uma "assistência técnica", ou seja, um Serviço de Atendimento ao Consumidor (SAC). A estrutura dessa prestação de serviço representa um canal de comunicação entre a empresa e o consumidor, após a comercialização do produto. Uma central de atendimento, além de assegurar o fornecimento de informações complementares sobre o produto, pode funcionar como um radar que capta, processa e analisa a opinião dos consumidores. Como resultado desse serviço, tem-se o aprimoramento do produto, de acordo com as expectativas e desejos dos consumidores;

- tomada de decisão por parte do consumidor, quanto a uma escolha segura que atenda às suas necessidades.

C - O Subsistema Embalagem de Alimentos: Esta etapa do processo compreende todos os elementos que dão forma à embalagem de alimentos e, consequentemente, que a viabilizam até chegar ao consumidor final. Portanto, são imprescindíveis as seguintes indagações:

\footnotetext{
${ }^{9}$ Usuários-líderes: Termo empregado para caracterizar uma parcela especial de consumidores, que apresentam necessidades semelhantes às do mercado, porém surgem meses ou anos antes que o resto do mercado as enfrente. Rust RT, Zahorik AJ, Keiningham TL. Mensurando o impacto financeiro da sua empresa: questões para a qualidade. Rio de Janeiro: Qualitymark; 1995. p.35.

${ }^{10}$ Diz-se das propriedades dos corpos que impressionam os sentidos. Dicionário Popular Brasileiro. Organizado por José Baptista da Luz. Rio de Janeiro: Civilização Brasileira; 1961.
} 
- forma-formato da embalagem: atende à expectativa do consumidor, quanto aos aspectos relacionados à especificidade do produto (retrata o conteúdo), conservação da integridade fisica do binômio produto/ embalagem, inviolabilidade-segurança, praticidade de manuseioabertura-uso, bem como quanto à sua estocagem na residência do consumidor;

- peso-volume: está de acordo com as normas legais vigentes, considera as exigências do mercado, no que se refere a hábitos de consumo (porções individuais, ou tamanho "familia") e permite uma análise comparativa com os demais produtos da mesma categoria;

- design e elementos gráficos: realça o produto na gôndola em face ao dos concorrentes. $\mathrm{O}$ emprego dessa força de comunicação, por intermédio de uma estética harmoniosa, pode representar uma vantagem competitiva.

A avaliação, por parte da empresa, dos itens discriminados nas etapas identificadas como “Estruturação da Embalagem de Alimentos" e "O Subsistema Embalagem de Alimentos" irá subsidiar a redefinição do processo, se necessário e poderá nortear a execução de uma embalagem de alimentos, que contemple e atenda ao grau de exigência do seu público-alvo.

D - A Embalagem de Alimentos e o Processo de Comercialização: Vem a ser a colocação da embalagem de alimentos nos diversos canais de distribuição de bens de consumo. Neste momento, a empresa precisa considerar que a embalagem será um elo de ligação entre a empresa e o consumidor. Portanto, ela poderá ser determinante para o bom desempenho do produto no mercado. Assim, a embalagem deverá justificar a compatibilidade do produto com o segmento de mercado escolhido, justificar a definição do preço (processo tecnológico), apresentar e promover a venda do produto, principalmente nos supermercados, um dos mais importantes canais de distribuição do tipo "auto-serviço".

A clara discriminação de todos os itens, permitirá que a aplicação do programa de avaliação identifique e mensure os possíveis desvios, que venham a comprometer a obtenção de um resultado final favorável desta etapa. A adoção de uma forma de categorizar os atributos relacionados anteriormente, poderá facilitar a avaliação de todas as respostas levantadas, para as indagações pré-formuladas. Assim, devem ser considerados os seguintes métodos de avaliação:

- agrupamento baseado na similaridade: formação de grupos de análise;

- formação de células, contendo o agrupamento das necessidades identificadas e conforme a freqüência com que ocorreram;

- formar níveis hierarquizados para refletir o pensamento do consumidor. Para a aplicação desse método, precisa haver uma sintonia muito forte entre o produtor e o consumidor. É a chamada administração através da observação direta. 


\subsection{Aspectos Sumarizadores}

É evidente o influente papel que a embalagem de alimentos exerce durante o processo de comercialização dos gêneros alimentícios. Por seu intermédio, a indústria de alimentos pode empregar uma linguagem promocional para atingir os mais exigentes centros de consumo, conquistar novos mercados, auxiliar o consumidor a tomar uma decisão segura, acerca dos efeitos consecutivos do consumo de alimentos sobre os aspectos de saúde pública, preservar clientes e conquistar novos usuários, bem como enfrentar a concorrência.

O comportamento dos indivíduos em relação aos hábitos de consumo baseia-se em um conjunto de elementos (símbolos, valores, sentimentos, atitudes, religião, idioma, entre outros), que são reordenados permanentemente em função de mudanças ocorridas na estrutura das instituições primárias, secundárias, bem como em virtude do próprio processo de aprendizado do consumidor. Este último, está estreitamente relacionado ao grau de exposição do indivíduo às influências ambientais, que podem tornar suas experiências adquiridas mais ricas ao longo da prática comercial exercida.

No processo de tomada de decisão pela aquisição ou não de um determinado produto, o consumidor monta uma estrutura de avaliação, no sentido de satisfazer suas necessidades e desejos. $O$ conjunto informativo inserido nas embalagens de alimentos configura um fator estimulador, a partir do qual o consumidor pode estabelecer uma lista organizada de atributos preferenciais.

O investimento em qualidade na comunicação entre os agentes produtor e consumidor poderá reduzir custos e gerar aumento da receita, pois haverá potencial para o oferecimento de melhores produtos compatíveis com o ambiente competitivo da globalização. Por intermédio da embalagem é possivel avaliar a satisfação do consumidor, a participação de mercado do produto, bem como identificar a relação entre qualidade e lucro. É, portanto, esperado que as informações levantadas com o desenvolvimento deste estudo possam ajudar no planejamento e desenvolvimento de um programa que avalie a relação entre qualidade e lucro. 


\section{CAPÍTULO 3}

METODOLOGIA 


\section{METODOLOGIA}

\subsection{Considerações Gerais}

Nos últimos anos, percebe-se que o comportamento do consumidor vem apresentando alterações, pois tem sido mais exigente ao analisar o tipo de linguagem veiculada nos rótulos das embalagens dos produtos alimentícios. Esse comportamento reflete a preocupação do usuário em consumir alimentos que possuam atributos relacionados a um estilo de vida considerável saudável (Santos, 1991).

Observa-se que, muitas vezes, o consumidor pode encontrar certa dificuldade em adequar as informações contidas nas embalagens às suas necessidades diárias. Talvez, esse bloqueio no processo da comunicação seja decorrente da forma/ formato como as informações estão dispostas nas embalagens de alimentos.

Dessa forma, foram levantados dados sob a ótica dos agentes de produção e consumo de uma determinada categoria de produto alimentício, que podem vir a subsidiar o planejamento e desenvolvimento de um programa de avaliação da relação entre qualidade e lucro'. Ou seja, a análise do investimento aplicado no aprimoramento da embalagem de alimentos e os benefícios decorrentes, tais como: melhor desempenho da embalagem no seu papel de veículo de comunicação, satisfação e retenção do consumidor, participação de mercado e, consequentemente, os lucros.

A estruturação desse programa poderá funcionar como um instrumento inovador de apoio na tomada de decisão sobre o produto e, particularmente, de sua embalagem, cujo contexto está voltado para os preceitos da globalização da economia e de mercados de consumo. Permitindo, dessa forma, prever e/ou analisar o retorno dos resultados com vistas à melhoria da qualidade, isto é, os esforços empregados pelo marketing, serviços e aspectos financeiros.

\subsection{Propósito e Foco do Estudo}

Como já foi ressaltado anteriormente, a elaboração da embalagem de alimentos adquire um caráter multidisciplinar, pois conta com o envolvimento de vários profissionais ligados ao processo como um todo. $\mathrm{O}$ resultado esperado expressará, não só, as necessidades do impacto mercadológico, como também o elemento-chave do processo de comercialização.

\footnotetext{
${ }^{1}$ Rust RT, Zahorik AJ, Keiningham TL. Mensurando o impacto financeiro da sua empresa: questões para
} qualidade. Rio de Janeiro: Qualitymark Editora; 1995. 
A decodificação da mensagem contida na embalagem pelo consumidor, pode desencadear outras reações em seu comportamento. Quanto mais próxima essa linguagem estiver das expectativas e necessidades do consumidor, mais fortalecido estará o entendimento entre produtor e consumidor.

$\mathrm{O}$ surgimento de novos hábitos alimentares em busca de produtos mais saudáveis, bem como o oferecimento de uma diversificada gama de gêneros alimentícios fabricados no ambiente interno $\mathrm{e}$ externo à nacionalidade do público consumidor, apresentam-se como uma importante oportunidade para a realização de um estudo, quanto ao conteúdo informativo inserido nas embalagens de alimentos e a sua contribuição para a tomada de decisão pela compra ou não de um dado gênero alimentício.

Por considerar a embalagem uma peça importante, se não a mais básica e relevante, de comunicação de um produto, o objetivo central deste trabalho foi o de analisar as estratégias adotadas pelo consumidor por ocasião da seleção, aquisição e uso dos alimentos, no que tange o conteúdo informativo das embalagens de alimentos, bem como o de identificar formas alternativas de apresentar a linguagem expressa no rótulo da embalagem de alimentos. $O$ estudo em questão, também, está voltado para aspectos e serviços que possam prestar uma "assistência técnica" ao consumidor e complementar, futuramente, as informações nela contida.

Assim, o propósito deste trabalho foi o de desenvolver um estudo exploratório internacional comparado (comentado, detalhadamente, em item específico adiante) sobre o entendimento do comportamento empresarial e do consumidor, acerca do uso que faz do conteúdo das informações contidas nas embalagens de alimentos. $O$ enfoque da pesquisa voltou-se para os aspectos relacionados à identificação da estrutura ordenada de preferência pelos atributos de uma dada categoria de produto alimentício. Dessa forma, destacaram-se os seguintes fatores:

- identificação, a princípio, dos atributos de um item alimentício considerados relevantes pelo consumidor;

- identificação de um conjunto de informações que, segundo o entendimento do consumidor, possa estabelecer uma relação entre a ingestão de certos alimentos e o seu impacto sobre a saúde pública. Nesse sentido, buscou-se verificar se o fato do consumidor possuir algum problema de saúde, por exemplo, poderia ou não influenciar a maneira como a embalagem é utilizada por ocasião da escolha-aquisição de um gênero alimentício;

- disposição das informações contidas nas embalagens, com melhor utilização do espaço útil (interno e externo) da embalagem;

- forma/ formato do conteúdo informativo expresso nos rótulos das embalagens;

- apresentação das informações, contando com unidades de medida de aplicação clara e objetiva, para o preenchimento das recomendações nutricionais diárias;

- utilização de serviços que pudessem a complementar, posteriormente, as informações inseridas na embalagem. 
Em face da complexidade do assunto, a realização deste trabalho teve a atenção centrada nas reaç̃̃es dos consumidores brasileiros e norte-americanos, durante o processo de comercialização e, sobretudo, acerca das etapas de conservação, preparo, consumo e descarte do binômio produto/ embalagem, bem como no procedimento adotado pelo setor empresarial dos dois paises em questão, quanto ao seu entendimento sobre a embalagem de alimentos. $O$ desenvolvimento de um estudo com essa preocupação levou à identificação de medidas alternativas, no sentido de aprimorar a apresentação de um conjunto de informações, que é imprescindivel para a promoção e venda dos gêneros alimentícios, segundo as exigências do mercado de consumo.

\subsection{Premissas do Estudo}

Como o estudo focaliza o entendimento dos agentes de produção e consumo do setor alimentício, tem-se como hipóteses as seguintes conjecturas:

- devido à diversificada gama de cereais (Apêndice 1) ofertados aos consumidores norteamericanos, em comparação com a composição do mercado varejista brasileiro, para as categorias de cereais matinais, presumiu-se que o perfil do consumidor norte-americano apresentasse características diferenciadas e peculiares quando comparadas com $o$ comportamento (hábitos, padrão de consumo) do consumidor brasileiro de cereais. Em termos de características peculiares do consumidor norte-americano, levou-se em consideração as regras normativas estabelecidas pela "Food and Drug Administration - FDA" que compreendem regulamentações para rotulagem de alimentos na comercialização de produtos alimentícios, bem como alguns aspectos tais como estilo de vida, poder de compra, diversidade de produtos oferecidos pelo mercado consumidor, entre outros;

- em função da composição dos mercados varejistas de cereais brasileiro e norte-americano, admitiu-se que o setor produtivo deste último estivesse mais bem estruturado em relação ao do brasileiro. Nesse sentido, admitiu-se, também, um maior grau de consciência por parte dos agentes de produção e consumo norte-americanos, em comparação com o grau de entendimento dos profissionais e consumidores brasileiros de cereais.

Dessa forma, apesar de se tratar de um estudo de caráter exploratório, foi possivel fazer comparações quanto ao padrão de consumo (hábitos, valores, entre outros) em relação ao volume de produtos comercializados nos países (Brasil e Estados Unidos) objetos do estudo, bem como quanto aos aspectos ligados ao entendimento dos agentes de produção e consumo, acerca das embalagens de alimentos, mais especificamente, do setor de cereais.

Estudos que envolvam populações diferentes, Dawar e Parker (1994) ressaltam a importância do estabelecimento de um quadro referencial acerca das características (aspectos psicológicos e psicossociais) comportamentais dos consumidores de ambos os países. Ao analisar o comportamento do consumidor, os referidos pesquisadores consideram relevante a identificação de sinais (atributos) de qualidade conferidos a um dado produto pelo consumidor. Por exemplo, marca, preço, valor nutricional, entre outros são atributos de qualidade cujo grau de valorização (ordenação) pode variar substancialmente de um país para outro. Essas variações são itens determinantes para a segmentação do mercado, adaptação do composto de marketing e, sobretudo, para a satisfação do padrão cultural adotado em uma dada sociedade. 
Com base no parecer de Colwell (1990), Sykes (1990) e Zikmund (1989), um dos principais elementos para a realização de uma pesquisa é a explicitação clara da situação-problema por parte do pesquisador, no sentido de que suas expectativas sejam atendidas ao final do estudo. Assim, a pesquisa exploratória auxilia o pequisador a identificar áreas com problemas e seus correspondentes "sintomas" (Zikmund, 1989, p. 107). Para Green e Tull (1975) a pesquisa exploratória é um dos primeiros passos a ser tomado e do qual decorre um conjunto de inferências que poderão subsidiar o gerenciamento de ações futuras. $O$ desenho desse estudo é caracterizado por grande flexibilidade, informalidade, pouca estruturação e específica versatilidade.

Levando-se em consideração as assertivas mencionadas, o desenvolvimento do presente trabalho foi fundamentado nas seguintes etapas, a saber:

- uma resenha literária voltada para as tendências do comportamento de compra dos consumidores brasileiros e norte-americanos, bem como para a análise de aspectos ligados ao aprimoramento da embalagem de alimentos, como uma medida estratégica para a obtenção de um retorno lucrativo;

- uma investigação científica mais apurada sobre o fenômeno, que envolve o processo de tomada de decisão do consumidor pela compra ou não de gêneros alimentícios, a partir do conteúdo informativo nela inserido;

- um estudo exploratório comparativo acerca do conteúdo informativo das embalagens de alimentos, segundo a ótica brasileira e norte-americana dos agentes de produção e consumo.

Nesse sentido, foram observadas as questões legais que normatizam a comercialização de produtos alimentícios em ambos os países (Brasil e Estados Unidos). Quanto às questões legais norteamericanas, levou-se em consideração as novas regulamentações estabelecidas pela "Food and Drug Administration - FDA" - do Departamento de Saúde e Serviços Humanos, bem como as normas de Alimento Seguro e Inspeção de Serviço, do Departamento de Agricultura dos Estados Unidos.

As novas regulamentações propostas pela "Food and Drug Administration - FDA" foram publicadas em 1993 e tem estado em vigor desde então. O estabelecimento dessas regras de rotulagem tiveram o propósito de tornar mais claro o conteúdo informativo impresso nas embalagens de alimentos, de ajudar os consumidores na escolha por uma alimentação mais saudável, bem como o objetivo de oferecer um incentivo às empresas do setor alimentício no sentido de aprimorarem a qualidade nutricional de seus produtos.

No processo de comercialização de gêneros alimentícios, a responsabilidade da "Food and Drug Administration - FDA" é assegurar ao mercado consumidor norte-americano os beneficios decorrentes de uma rotulagem elaborada adequadamente. A Nutrition Labeling and Education Act fiscaliza o sistema de rotulagem nutricional, de tal forma que os descritores do conteúdo nutricional

\footnotetext{
${ }^{2}$ Site: FDA/CFSAN (http://vm.cfsan.fda.gov): U.S. Food and Drug Administration - Center for Food Safety \& Applied Nutrition - A Food Labeling Guide - The New Food Label
} 
dos alimentos e as mensagens / chamadas de saúde preencham as determinações legalmente exigidas.

No que tange às questões legais brasileiras, foram considerados o Codex Alimentarius e a Lei $\mathrm{n}^{\circ}$. 8078 - Código de Defesa do Consumidor - publicada em 1990. O primeiro normatiza a comercialização internacional de produtos alimentícios e o segundo dispõe sobre a proteção do consumidor e atribui outras providências.

O presente estudo analisou as estratégias adotadas pelo consumidor por ocasião da seleção, aquisição e uso dos alimentos, no que tange o conteúdo informativo das embalagens de alimentos. É através da embalagem, um dos importantes instrumentos de marketing, que o consumidor toma sua decisão pela compra ou não de um produto, em questão de segundos, diante da gôndola do supermercado.

\subsection{Método}

Segundo Selltiz et alli (1974), a pesquisa qualitativa é empregada quando o investigador deseja compreender, com maior profundidade o comportamento dos indivíduos para um dado fenômeno e, consequentemente, conseguir nova compreensão acerca do objeto do estudo.

De acordo com Parasuraman (1986), a pesquisa qualitativa compreende coleta, análise e interpretação de dados que, basicamente, não são quantificados segundo os critérios da estatística paramétrica. A ausência da mensuração dos dados obtidos, aponta uma provável tendência dos fatos (não conclusivos). A apresentação das idéias formuladas a partir dos resultados obtidos, adquire uma configuração descritiva. Gordon e Langmaid (1988) apud Colwell (1990), enfatizam o fato de que a pesquisa qualitativa tem a sua preocupação centrada na compreensão dos fatos e não em sua mensuração. A composição da amostra, além de ser pequena não é constituída por meio de um critério probabilístico. Em geral, a amostra foi definida a partir de uma escolha intencional (Sampson, 1991).

Em linhas gerais, as etapas e os procedimentos de uma pesquisa qualitativa constituem a definição do problema, do objeto de estudo, bem como da correspondente metodologia a ser empregada; a seleção e o recrutamento da amostra; a definição do trabalho de campo; a análise e interpretação dos dados levantados e, finalmente, a elaboração do registro e/ou documento final, contendo conclusões e recomendações a serem implementadas oportunamente (Sykes, 1990).

Com a realização da pesquisa exploratória o pesquisador pode identificar as inúmeras, ou pelo menos a maioria delas, possíveis idéias sobre o fenômeno estudado, clarear conceitos (por exemplo, o grau de satisfação do consumidor com os atributos de um dado produto), reconhecer as variáveis relevantes, bem como formular novos cursos de ação alternativos. Espera-se obter, portanto, um maior aprofundamento do conhecimento no que tange ao entendimento das atitudes, que envolvem os componentes cognitivo (vivência e experiência do entrevistado), afetivo 
(sentimento em relação aos produtos, à marca/ empresa) e comportamental (reação diante de determinados estímulos de marcas e produtos) do consumidor; as opiniões (manifestação de atitudes); o grau de conscientização do consumidor em relação ao objeto do estudo, bem como quanto ao conhecimento das motivações (impulsos, necessidades e desejos), o que permite prever e compreender o comportamento de escolha, compra e uso dos produtos pelos consumidores. Os resultados advindos da pesquisa qualitativa devem contribuir para a formulação de hipóteses, que venham a ser testadas com o desenvolvimento futuro de pesquisas quantitativas (Mattar, 1994).

De acordo com Jorgensen (1989), Glaser e Strauss (1967), apud Punnett e Shenkar (1996), no gerenciamento do trabalho de campo de uma pesquisa internacional, o pesquisador ainda está procurando definir as questões certas para dado estudo, bem como precisa estar atento aos viéses culturais que carrega para todo projeto de pesquisa. Nesse sentido, os processos relacionados à coleta e análises dos dados e geração de teoria estão mais próximos de uma pesquisa qualitativa do que quantitativa. Esta é uma das mais fortes razões teóricas para defender a importância da pesquisa qualitativa, já que ela é a maneira mais robusta de gerar teoria.

Para investigar e compreender experiências/ situações de consumo, Hirschman e Holbrook (1986, 1992) destacam que o investigador deve envolver-se pessoalmente com o fenômeno o quanto for possivel. Dessa forma, o lado humano do pesquisador e sua habilidade de pensar, sentir, agir e avaliar como os consumidores fazem facilitarão seu entendimento em relação às práticas de consumo objeto de estudo. Ainda segundo os autores mencionados, o pesquisador precisa ter a flexibilidade de adotar/ de se colocar na postura do consumidor; ser receptivo às estruturas e aos significados dos respondentes; adquirir (produto foco de estudo) para entender as experiências dos consumidores em seus termos. Assim, efetiva observação das ocupações humanas é virtualmente impossivel sem algum grau de participação acerca do que está sendo observado.

$\mathrm{Na}$ área de Marketing, torna-se imprescindível tomar conhecimento do que está acontecendo, de que forma ocorre, bem como as causas dessas ocorrências. Ao conhecê-las efetivamente, poder-seá atuar no processo com a adoção de medidas práticas, que reduzam o risco existente na escolha dentre inúmeras alternativas ofertadas.

Espera-se que os resultados obtidos, com o desenvolvimento deste estudo exploratório internacional comparado, possam subsidiar as diversas áreas de atuação do profissional de Marketing, no que se refere à tomada de decisão quanto ao composto do produto. Portanto, destaca-se a utilidade do método de pesquisa, no que se refere aos seguintes aspectos:

- identificação dos fatores determinantes para os consumidores brasileiros e norte-americanos na aquisição ou não de um gênero alimentício, a partir do conteúdo informativo inserido na embalagem de alimentos;

- aprimoramento do modelo sistêmico (Castro, 1994) para o desenvolvimento de embalagens de alimentos, com o levantamento de significativas informações dos profissionais, de ambos os paises, das empresas produtoras do gênero alimentício em estudo, acerca do padrão de consumo do público-alvo de cereais. 
Em virtude da complexidade da técnica escolhida para a consecução do estudo em questão, tomouse o cuidado de estudá-lo detalhadamente para garantir a validade interna da pesquisa. Para tal, por intermédio de um minucioso estudo da arte foram aprofundados os conhecimentos sobre o assunto, os quais ofereceram adequada sustentação para a definição dos procedimentos adotados durante o desenvolvimento do trabalho de campo. Entrou-se, também, em contato com profissionais especializados em pesquisa qualitativa, com o objetivo de assegurar a qualidade técnica dos documentos (filtro e roteiro) relacionados ao recrutamento dos consumidores, bem como à aplicação das entrevistas pessoais.

Cabe, ainda, ressaltar que foram tomados os seguintes cuidados éticos tradicionais recomendados:

- no Brasil, país onde a pesquisa tem origem, as entrevistas foram realizadas pela própria pesquisadora, a partir de um roteiro de pesquisa;

- nos Estados Unidos, não sendo o país da língua nativa da pesquisadora, foram tomados os seguintes cuidados para garantir as premissas de uma pesquisa internacional comparada:

- para as etapas de recrutamento e realização das entrevistas pessoais, contou-se com uma equipe de entrevistadores com fluência na língua inglesa;

- a pesquisadora participou do processo de coleta de dados, bem como fez a coordenação total do trabalho de campo, para garantir o alcance dos objetivos propostos no estudo;

- a pesquisadora contou com o suporte técnico-administrativo do Departamento de Marketing da Georgia State University, para a obtenção da equipe de entrevistadores, bem como para promover os contatos com outras unidades de ensino especializadas em embalagens de alimentos, o que possibilitou o agendamento de entrevistas e uma visita à Faculdade de Embalagem, da Universidade Estadual de Michigan (Michigan State University - School of Packaging).

- aos dados levantados, foi atribuído um tratamento, exclusivamente, de cunho acadêmico.

Ainda, para atender às premissas de um estudo internacional comparado, cabe destacar o processo denominado "back translation" (versão do inglês e tradução para o português) dos documentos (modelo sistêmico, filtro e roteiro das entrevistas) empregados na realização do estudo. Com esse procedimento, a pesquisadora procurou assegurar a verissimilhança da linguagem empregada em ambos os países (Brasil e Estados Unidos) integrantes da pesquisa comparada, o que permitiu a identificação de amostras similares, bem como possibilitou a posterior análise comparativa das informações levantadas com o desenvolvimento do estudo.

Quanto ao modelo sistêmico, ressalta-se o fato desse material ser parte integrante de um artigo já vertido para o inglês e publicado, na íntegra, em uma revista norte-americana (A systemic view and validation of food packaging in the Brazilian context: a case study in yogurt manufacturing companies. The Journal of Food Products Marketing, vol. 4 (4) 1997, p. 75-91). 


\subsection{Procedimento}

\subsubsection{O mercado de cereais}

Nos últimos anos, os cereais matinais vêm recebendo significativo destaque. $\mathrm{O}$ desempenho dessa categoria de produtos no mercado mundial tem fornecido subsídios para a formulação das ações de marketing, bem como tem contribuído para exemplificar possíveis implicações relacionadas à integração (globalização) de economias em desenvolvimento. Nesse sentido, Olsen e Granzin (1994) desenvolveram um estudo e empregaram os cereais para analisar como os níveis de desenvolvimento econômico de diversos países afetam a estrutura natural dos canais de distribuição.

Com base nas considerações apresentadas sobre o contexto atual para o ambiente empresarial, identificou-se na literatura que a categoria de cereais da marca Kellogg's, mais especificamente, os segmentos de produtos denominados "fibra" e "multi-ingredientes", vinham apresentando significativa expansão da marca, em função da mensagem voltada para adultos preocupados com uma alimentação saudável e prática (Miller 1993, Kirk 1994, Langbo, 1995 e Kirk, 1995), bem como em virtude da adequação do produto às exigências de uma economia globalizada (Liesse, 1992 e Pritchard, 1993).

No sentido de atender às necessidades de um centro de consumo mais exigente, verificou-se também o interesse dos produtores de cereais e biscoitos utilizarem o produto "All Bran", como ingrediente-chave no desenvolvimento dos itens alimentícios denominados "cookies" (Rickard, 1995).

Em um artigo publicado na revista Retail Business-Market Reports (1993), foi destacado o contínuo e crescente consumo do cereal pertencente à marca "Muesli", principalmente, entre consumidores adultos. $\mathrm{O}$ referido cereal vinha sendo considerado um produto com valor agregado, em função da adição de frutas (coco, abacaxi, uva) desidratadas a uma mistura de cereais (aveia, trigo, milho), apresentando atributos ligados às questões de conveniência e alimentação saudável, fatores estes, que têm influenciado as tendências mundiais no consumo de alimentos. Em vista destes elementos facilitadores, optou-se por desenvolver o estudo, empregando as categorias de cereais matinais, por apresentarem características pertinentes ao objetivo da pesquisa em questão e, sobretudo, por serem comercializadas em ambos os países, cujas populações foram definidas como foco do estudo.

Em termos de dados extraídos do mercado de consumo brasileiro e norte-americano, o Quadro 3.5.1, retrata graficamente, qual foi o consumo de cereais e como se comportou o mercado em relação à essa categoria, no ano de 1998. 
Quadro 3.5.1 Consumo de cereais

\begin{tabular}{|c|c|c|c|c|}
\hline \multirow[t]{2}{*}{ PRODUTOS } & \multicolumn{4}{|c|}{ VENDAS } \\
\hline & Vol.(mil Kg) & "Share" (Vol.) & Fatur. (mil US\$) & "Share" (US\$) \\
\hline BRASIL & & & & \\
\hline Total & $15,765.7$ & 100.00 & $134,909.4$ & 100.00 \\
\hline Kellogg's & $8,745.5$ & 55.70 & $81,486.9$ & 59.70 \\
\hline Concorrentes & & & & \\
\hline Nestlé & $1,853.5$ & 11.70 & $17,369.0$ & 13.60 \\
\hline Nutrifoods & $1,552.1$ & 9.80 & $8,626.8$ & 6.40 \\
\hline Outros & $3,614.6$ & 22.8 & $27,426.7$ & 20.30 \\
\hline EUA & & & & \\
\hline Total & $532,852.64$ & 100.00 & $1,538,066.94$ & 100.0 \\
\hline Kellogg's & $168,412.00$ & 31.6 & $486,997.12$ & 31.7 \\
\hline Concorrentes & & & & \\
\hline General Mills \& Ralston & $146,844.78$ & 27.6 & $509,213.63$ & 33.1 \\
\hline Post \& Nabisco & $87,426.83$ & 16.4 & $242,621.20$ & 15.8 \\
\hline Quaker & $50,066.33$ & 9.4 & $133,843.02$ & 8.7 \\
\hline Outros & $80,102.69$ & 15.0 & $166,391.77$ & 10.7 \\
\hline
\end{tabular}

Elaborado pela autora, a partir de:

Brasil - Relatório Nielsen Cereais, 1998

EUA - Information Resources, 1998

\subsubsection{Caracterização das empresas}

Inicialmente será feita uma caracterização das empresas produtoras de cereais matinais com atuação nos mercados, entre outros, brasileiro e norte-americano. Os Quadros 3.5.2 e 3.5.2a sumarizam o registro dos dados obtidos.

Os dados caracterizam empresas do setor alimentício que atuam na área de cereais matinais, bem como na produção de alimentos de conveniência - "convenience food". Originariamente, a Kellogg Company foi fundada nos Estados Unidos em 1906, na cidade de Battle Creek, estado de Michigan com o nome de The Batle Creek Toasted Corn Flake Company.

Desde a data de sua fundação até os dias de hoje, a Kellogg Company expandiu suas atividades e encontra-se representada em seis continentes. Sua atuação global está dividida em quatro unidades de operação: Kellogg América do Norte, Kellogg Europa, Kellogg Ásia-Pacífico e Kellogg América Latina. 
$\mathrm{Na}$ área de produção, conta com 35 fábricas localizadas em 22 países, entre eles o território brasileiro. No que tange ao canal de distribuição, o produto tem sido distribuído em 160 países. Conta com uma força global de trabalho da ordem de 14.300 funcionários. Só no escritório central em Battle Creek, em Michigan, EUA, atuam 800 funcionários.

A Kellogg Company apresenta um portifólio (Apêndice 2) composto por mais de 40 tipos diferentes de cereais matinais. No que tange à comercialização dos produtos confeccionados, os Estados Unidos absorvem $35 \%$ do volume produzido.

Segundo os dados fornecidos pela empresa norte-americana, em 1997 o valor líquido aquirido com as vendas de cereais matinais alcançou o montante de US\$ 6,830 milhões. A participação em volume foi $32,9 \%$. Em 1998, em virtude de uma retração da categoria, bem como de segmento consitituído por marcas com baixo preço, a participação da empresa, em termos de volume, na categoria desse gênero alimentício foi da ordem de $31,4 \%$.

No Brasil, a empresa registrada como o nome Kellogg Brasil \& Cia, foi estabelecida na cidade de São Paulo e o início das atividades deu-se no ano de 1961.

Além da categoria de cereais matinais, a empresa brasileira começou a produzir alguns produtos da linha "alimentos de conveniência". No mercado consumidor os produtos são encontrados sob as marcas "Kadri-Krispies" (barra de flocos de arroz, sabor marshimallow ou chocolate) e "Mueslix Bars" (barrinhas de cereais, sabores chocolate marron ou branco, coco, avelãs). $\mathrm{O}$ produto de marca "Mueslix Bars" tem como principal concorrente aquele denominado "Nutry".

No final dos anos 90, a empresa brasileira comprou a marca "Superbom", nome considerado tradicional na comercialização produtos naturais (suco de uva, mel). Era um dos concorrentes da marca "Kellogg's" no segmento de cereais matinais.

Entre o antigo e o novo produto, as diferenças foram básicas. Com a nova aquisição, a empresa conservou a marca "Superbom", porém, reformulou toda a linha de produção de cereais matinais para manter o mesmo padrão de qualidade da marca "Kellogg's". Foi empregada uma economia de custo no desenvolvimento do novo produto de marca "Superbom". Os cereais matinais passaram a apresentar uma diversidade menor de vitaminas (cinco a menos), não foi adicionado o ingrediente "extrato de malte", bem como os "grids" - grades - de milho comprados contém grãos menores. Esse tipo de grão deu origem a um produto com flocos menores. A empresa empregou a diferenciação no tamanho dos flocos do cereal como uma estratégia, no sentido de manter o "status premium" da marca "Kellogg's". 
A tecnologia de produção empregada para a "Superbom" alterou muito pouco o sabor do cereal em relação à marca "Kellogg's". Segundo a pessoa entrevistada, em relação aos cereais da empresa, alguns consumidores consideraram o produto de marca "Superbom" de qualidade superior. $O$ produto era comercializado em sacos plásticos e continha informações que atendiam às exigências legais, como por exemplo, o Cadastro Nacional de Pessoa Jurídica - CNPJ e o nome do fabricante.

Ainda de acordo com a mesma pessoa, pouquíssimos consumidores liam o rótulo para identificar o nome do fabricante. Normalmente, os usuários atentavam para a marca-chave do produto impressa na face principal da embalagem. Por essa razão, no geral, a aquisição da referida marca pela empresa não foi percebida pelos consumidores de cereais matinais.

Tanto a empresa brasileira como a norte-americana comercializavam alguns tipos de cereais matinais que produziam em embalagens individuais. Ambos os respondentes consideraram que a unidade de consumo era uma forma cara de se adquirir cereal matinal. Entretanto, o consumidor não enfrentava problemas em conservar o cereal sempre crocante depois de abrir a embalagem. As unidades de consumo aumentavam as ocasiões de consumo do produto (escola, serviço, "snack", entre outros) e, além disso, possibilitavam o usuário de estar, frequentemente, variando o tipo de cereal que viesse ser adquirido e consumido. 
Quadro 3.5.2 Caracterização da empresa - Brasil / 1998

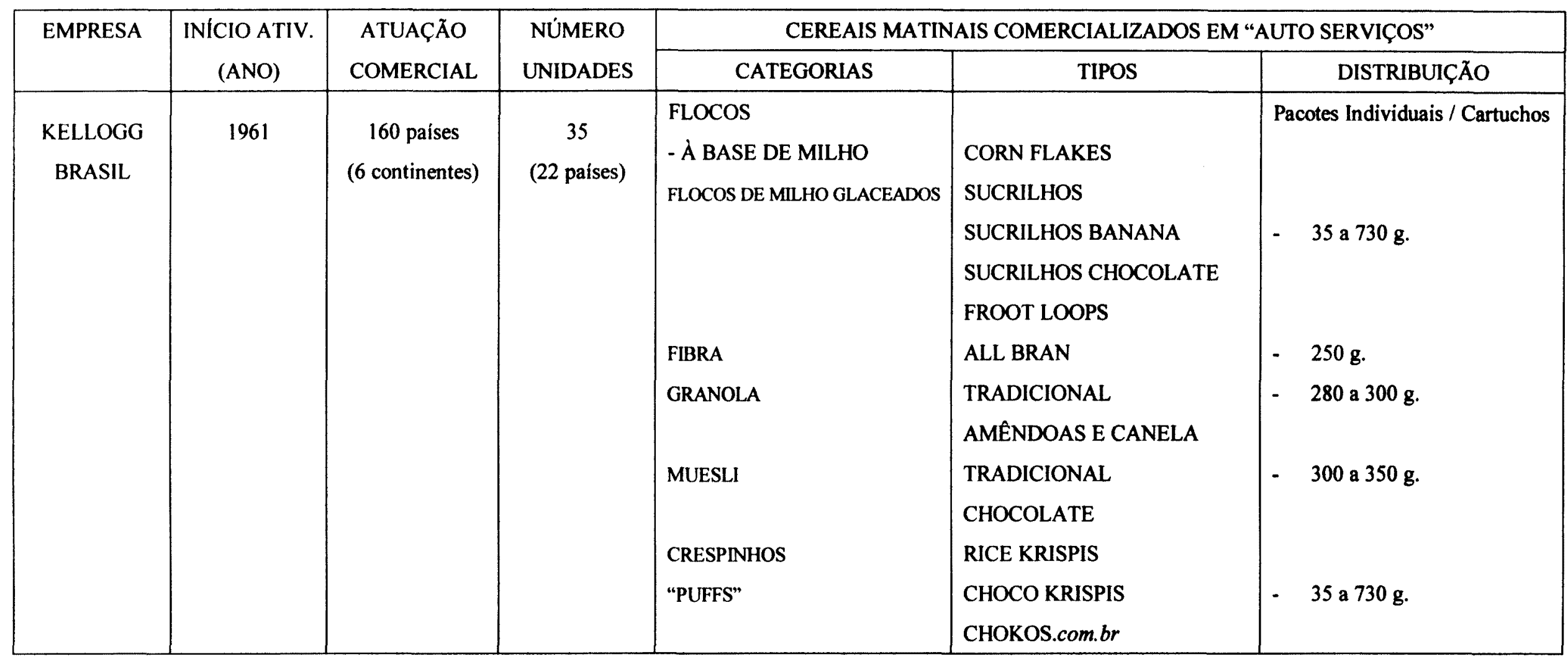

Elaborado pela autora a partir de:

Informações verbais e documentos fornecidos pelo entrevistado 
Quadro 3.5.2a

Caracterização da empresa - EUA / 1998

\begin{tabular}{|c|c|c|c|c|c|c|}
\hline \multirow[t]{2}{*}{ EMPRESAS } & \multirow{2}{*}{$\begin{array}{c}\text { ANO } \\
\text { FUNDAÇÃO }\end{array}$} & \multirow{2}{*}{$\begin{array}{c}\text { ATUAÇÃO } \\
\text { COMERCIAL }\end{array}$} & \multirow{2}{*}{$\begin{array}{l}\text { NÚMERO } \\
\text { UNIDADES }\end{array}$} & \multicolumn{3}{|c|}{ CEREAIS MATINAIS COMERCIALIZADOS EM "AUTO SERVIÇOS" } \\
\hline & & & & CATEGORIAS & TIPOS & DISTRIBUIÇÃO \\
\hline $\begin{array}{l}\text { KELLOGG } \\
\text { COMPANY }\end{array}$ & 1906 & $\begin{array}{c}160 \text { paises } \\
\text { (6 continentes) }\end{array}$ & $\begin{array}{c}35 \\
\text { (22 paises) }\end{array}$ & 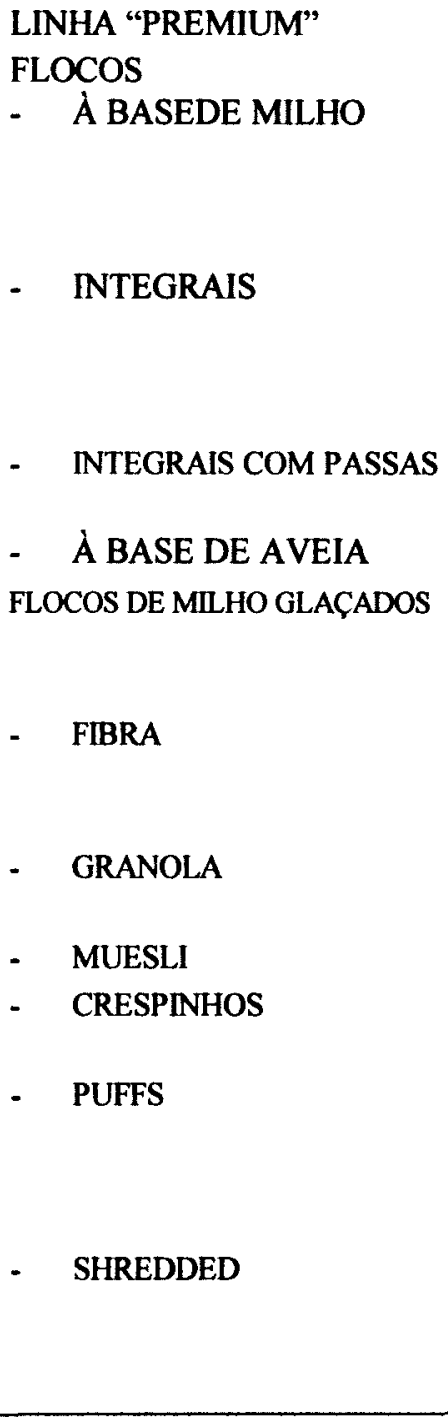 & $\begin{array}{l}\text { COUNTRY INN SPECIALTIES } \\
\text { CORN FLAKES; HONEY CRUNCH } \\
\text { CORN FLAKES; JUST RIGHT - } \\
\text { FRUIT \& NUT/CRUNCH; SMART } \\
\text { START CEREAL } \\
\text { BRAN FLAKES; COMPLETE; } \\
\text { COMPLETE OAT BRAN } \\
\text { FLAKES; WHEAT BRAN } \\
\text { FLAKES } \\
\text { RAISIN BRAN; RAISIN BRAN } \\
\text { CRUNCH } \\
\text { OAT BRAN } \\
\text { FROSTED FLAKES; FROOT } \\
\text { LOOPS; MARSHMALLOW } \\
\text { BLASTED; SMACKS } \\
\text { ALL BRAN; ALL BRAN - BRAN } \\
\text { BUDS; NUTRI-GRAN GOLDEN } \\
\text { WHEAT/ALMOND RAISIN } \\
\text { HEALTHY CHOICE LOW FAT } \\
\text { GRANOLA (C/ OU S/ PASSAS) } \\
\text { HEALTHY CHOICE MUELIX } \\
\text { COCOA KRISPIES; SPECIAL K; } \\
\text { RICE KRISPIES } \\
\text { APPLE JACKS; CRUNCHERROS; } \\
\text { CORN POPS; PUFFED RICE / } \\
\text { WHEAT; RAZZLE DAZZLE RICE } \\
\text { KRISPIES } \\
\text { CRISPIX; HEALTHY CHOICE } \\
\text { BISCUITS; (FROSTED) MINI - } \\
\text { WHEATS; STRABERRY SQUARES; } \\
\text { WHEATS }\end{array}$ & $\begin{array}{l}\text { - pacotes: } 250 \mathrm{~g} . \\
\text { - cartuchos: } 21 \text { a } 680 \mathrm{~g} . \\
\text { - cartuchos: } 25 \text { a } 490 \mathrm{~g} . \\
\text { - cartuchos: } 35 \text { a } 516 \mathrm{~g} . \\
\text { - cartuchos: } 420 \mathrm{~g} . \\
\text { - cartuchos: } 28 \text { a } 879 \mathrm{~g} . \\
\text { - cartuchos: } 50 \text { a } 488 \mathrm{~g} . \\
\text { - cartuchos: } 18 \text { a } 507 \mathrm{~g} . \\
\text { - cartuchos: } 510 \mathrm{~g} . \\
\text { - } \quad \text { cartuchos: } 434 \mathrm{~g} . \\
\text { - cartuchos: } 18 \text { a } 519 \\
\text { cartuchos: } 18 \text { a } 553 \mathrm{~g} .\end{array}$ \\
\hline
\end{tabular}

Elaborado pela autora a partir de: Informações verbais e documentos fornecidos pelo entrevistado 


\subsubsection{Estudo Exploratório Internacional Comparado - EEIC}

3.5.3.1. Evolução histórica e aplicação da pesquisa internacional comparada

$\mathrm{Na}$ linha de estudos internacionais comparados, constatou-se a utilização dos termos pesquisa comparada, pesquisa cruzada, pesquisa provocativa, pesquisa bilíngue, entre outros, com as correspondentes denominações em inglês - "compared research", "cross-cultural research", "provocative research" e "bilingual research". Ressalta-se a importância da aplicação da referida modalidade de pesquisa, principalmente, no que diz respeito ao desenvolvimento de uma metodologia específica para sua execução (Spínola, 1995).

O presente estudo também focalizou o conteúdo etnográfico e "cross-cultural" envolvido nos paises (Brasil e Estados Unidos) foco da pesquisa internacional comparada. Dentre os aspectos culturais destacam-se o idioma, crenças/ opiniões e valores.

Ainda, segundo o autor mencionado, os norte-americanos deram os primeiros passos, no final dos anos 60 e início da década de 70 . Entretanto, os europeus, principalmente os ingleses, apresentam uma tradição maior no desenvolvimento de pesquisas internacionais comparadas. De modo geral, uma pesquisa comparada permite avaliar como as organizações de um determinado país vêm a influência de instituições de outra nacionalidade sobre o seu comportamento padrão adotado, isto é, sobre os significados que vêm sendo atribuídos pelos membros constituintes de uma dada sociedade.

Essa linha de pesquisa, na área de Marketing, representa comparações sistemáticas sobre similaridades e diferenças. Schiffman e Kanuk (1991) ressaltam os desafios vivenciados pelo setor empresarial de vários países para a formação de alianças, bem como destacam os benefícios decorrentes da pesquisa internacional comparada, sobretudo, quanto às suas implicações (expansão nas vendas, surgimento de oportunidades lucrativas, entre outras). Nesse sentido, para superar as diferenças apresentadas pelos mercados almejados, criam-se estruturas para assessar estratégias multinacionais. Essas estruturas subsidiam a tomada de decisão de forma a concentrar os esforços de marketing.

\subsubsection{Pesquisa internacional comparada: princípios e procedimentos}

No que tange à questão da aculturação da pesquisa, Schiffman e Kanuk (1991) e Chapman (1992) apud Tayeb (1994) ressaltam que o desenvolvimento de estudos comparados requerem do pesquisador um conhecimento acerca de aspectos psicológicos e psicossociais de ambos os países. Ou seja, deve-se considerar além do termo cultura, os aspectos relacionados com religião, idioma e demais conceitos julgados necessários pelo pesquisador para o entendimento analítico dos fatos estudados. $O$ pesquisador deve examinar as similaridades e diferenças existentes entre os entrevistados dos países envolvidos na pesquisa. Desse exame decorre a elaboração de um quadro referencial composto das similaridades e diferenças identificadas entre os consumidores entrevistados. Constata-se, portanto, que a metodologia de estudos que envolvam troca cultural devem considerar as técnicas disponíveis para a identificação de diferenças na linguagem, características estruturais das sociedades e valores dos pesquisadores e entrevistados. 
Quanto à parte operacional do assunto em questão, Hofstede (1984) apud Tayeb (1994) destaca a análise comparativa dos fatores (aspectos culturais, pesquisas já desenvolvidas) por intermédio dos quais as organizaçð̃es são estruturadas e organizadas. $O$ estudo das características sócioeconômicas (renda, mobilidade, acesso à mídia, empregabilidade, entre outros) dos países envolvidos no estudo auxilia na identificação das peculiaridades mercadológicas (Roth, 1995).

No que diz respeito ao fator levantamento e interpretação dos dados obtidos, a identificação de diferenças na estrutura de palavras e conceitos vem a ser um instrumento para medir, em amplo senso, como é vivida e entendida, pelas pessoas, realidades contrastantes entre duas sociedades. A estrutura das organizações é similar, o significado é diferente, pois este último depende de características sócio-culturais (Chapman, 1992 apud Tayeb, 1994). Portanto, a pesquisadora levou em consideração essa reflexão antes de estruturar o seu estudo. E o desenho da sua pesquisa, teve o seu escopo voltado para as dimensões (estrutura) e atitudes (procedimentos e ações para alcançar as dimensões).

Em uma pesquisa comparada, a obtenção de similaridades e diferenças entre os consumidores de diferentes sociedades e entre os pesquisadores configuram um dos aspectos mais dificeis de serem alcançados. Dessa forma, o pesquisador alargou os seus conhecimentos e tornou-se mais familiar acerca da cultura norte-americana, local em que se desenvolveu parte do estudo. De acordo com Kohls e Buller (1994), o investigador adaptou-se aos padrões da cultura local, que abrange os seguintes aspectos:

- adaptação ao novo e obtenção de um consenso entre os valores (centrais e periféricos) envolvidos;

- identificação dos padrões que determinam o que é certo ou errado (relativismo cultural);

- manutenção de equilíbrio entre os padrões/ valores já adquiridos com os que vivenciou durante a realização do estudo.

A seguir, é apresentada a estrutura metodológica do estudo exploratório internacional comparado (EEIC), com o detalhamento para os aspectos relativos ao conjunto de etapas do trabalho de campo, ao procedimento adotado para o recrutamento dos consumidores de cereais, à definição do plano amostral, à coleta de dados, bem como quanto à análise dos resultados esperados.

\section{$\Rightarrow$ Etapas do Trabalho de Campo}

O estudo exploratório internacional comparado (EEIC) é constituído de duas etapas distintas, isto é, o estudo foi realizado, não concomitantemente, com consumidores brasileiros e norteamericanos de cereais matinais. A primeira etapa do trabalho de campo, com a concessão de uma "Bolsa Sanduíche" por uma instituição nacional de fomento à pesquisa científica - CAPES, foi desenvolvida com consumidores e produtores de cereais norte-americanos. Posteriormente, ocorreu a segunda etapa do estudo e, portanto, a realização da pesquisa com consumidores $\mathrm{e}$ produtores de cereais brasileiros. 


\section{$\Rightarrow$ Recrutamento dos Entrevistados e Plano Amostral}

A definição pelo grupo de consumidores brasileiros e norte-americanos dependeu da aplicação de um filtro, isto é, foi utilizado um instrumento para selecionar os consumidores de cereais. Os indivíduos recrutados foram, preferencialmente, compradores e usuários de cereais matinais. Cabe ressaltar que os procedimentos empregados nesta fase da pesquisa foram voltados para o públicoalvo pertencente aos países (Brasil e Estados Unidos) foco do estudo. Portanto, tomou-se o cuidado de identificar duas amostras que apresentassem, o máximo possível, similaridades entre si.

O filtro aplicado (Apêndice 3) durante a fase de recrutamento de consumidores potenciais de cereais matinais, visou alcançar os seguintes objetivos:

- identificação de quem toma a decisão pela compra de gêneros alimentícios, ou seja, fique reconhecida a responsabilidade do consumidor pela compra e, posterior, consumo dos produtos por ele adquiridos;

- consumidores de cereais matinais, que preencheram os seguintes requisitos:

- brasileiros, compradores e usuários de cereais matinais e residentes em São Paulo;

- norte-americanos, compradores e usuários de cereais matinais e residentes em Atlanta, EUA;

- mulheres com nível universitário (concluído ou cursando) e que exercem uma atividade profissional fora de casa;

- frequência de consumo, de no mínimo, três vezes na semana.

Com a fase de recrutamento dos consumidores, obteve-se cinquenta respondentes (compradores e usuários) entrevistados, em cada uma das etapas do trabalho de campo. Dessa forma, computandose os dois grupos de consumidores (brasileiros e norte-americanos) de cereais matinais, o estudo apresenta uma amostra total de cem respondentes. De acordo com Aaker (1990) e Colwell (1990), o número ideal de entrevistas pessoais gira em torno de 8 a 10 entrevistas. Ainda, segundo os autores referenciados, uma amostra dessa amplitude é suficiente para que o investigador faça o seu estudo com a profundidade necessária. Levando-se em consideração as assertivas mencionadas anteriormente sobre as características de uma pesquisa de caráter exploratório, considera-se que a adequação do plano amostral superou os critérios científicos preconizados.

\section{$\Rightarrow$ Seleção da Amostra}

O consumo de cereais matinais nos Estados Unidos está vinculado a um forte traço cultural, ou seja, desde a infância esse gênero alimentício começa a fazer parte dos hábitos alimentares do norte-americano. Em virture dessa característica, bastante peculiar, não foi dificil identificar consumidores potenciais de cereais matinais.

No Brasil, durante a fase de recrutamento de consumidores potenciais de cereais matinais, verificou-se que o consumo do produto está vinculado à filosofia de vida praticada. Em geral, são consumidores que valorizam o "culto ao corpo", isto é, pessoas que praticam alguma modalidade de esporte (academia de ginástica, esporte "radical"), e/ou procuram consumir produtos ricos em 
fibra para regularizar o funcionamento do aparelho digestivo. Em virtude dos fatos apresentados, foi encontrada certa dificuldade para localizar consumidores de cereais matinais que preenchessem o perfil previamente definido no presente estudo. Exigiu, portanto, um esforço concentrado por parte da pesquisadora, no sentido de visitar organizações voltadas para a prática de esporte, arregimentar consumidores em estabelecimentos do tipo "auto-serviço", entre outros.

Em geral, a análise dos fatores culturais e subculturais está diretamente relacionada à questão do idioma expresso pelas sociedades (Schiffman e Kanuk, 1991). Para que o conjunto amostral da pesquisa oferecesse comparaç̃es efetivamente verdadeiras, levou-se em consideração a múltipla e interativa participação dos fatores que expressam uma nacionalidade, tais como: faixa etária, grau de instrução, atividade profissional, linguagem, estilo de vida, hábitos alimentares, comportamento de compra, entre outros.

\section{$\Rightarrow$ Coleta de Dados}

Para proceder ao levantamento de dados do presente estudo, foi adotada a técnica denominada entrevista em profundidade. Essa técnica é considerada mais adequada para a revelação de informação sobre assuntos complexos, emocionalmente carregados, para verificar os sentimentos subjacentes a determinada opinião apresentada, ou ainda, descrever situações, comportamentos e eventos que possam, por exemplo, refletir um certo estilo de vida (Selltiz et alli, 1974; Aaker, 1990 e Sykes, 1990).

O emprego da entrevista em profundidade gera novas descobertas sobre um certo fenômeno que poderão subsidiar o processo de tomada de decisão. Consequentemente, propicia a formulação de hipóteses a serem testadas em pesquisas futuras (Zikmund, 1989; Parasuraman, 1986 e Colwell, 1990). Segundo Aaker (1990), esta é uma vantagem que não pode ser tão bem explorada em pesquisas estruturadas.

\section{$\Rightarrow$ Instrumento de Coleta de Dados}

O instrumento de coleta dos dados deve assegurar que as informações obtidas reflitam as crenças, valores, hábitos e costumes específicos dos entrevistados. Sua definição está diretamente relacionada com o método de levantamento dos dados, dependendo da natureza do problema a ser investigado, das características da população amostrada, bem como do tamanho da amostra.

Nesse sentido, durante a realização das entrevistas em profundidade com os agentes consumidores e produtores de cereais, empregou-se um roteiro de entrevista que permitiu a adoção de um estilo mais livre de investigação (Chisnall, 1980). A definição pelo instrumento de pesquisa fundamentouse nas considerações formuladas anteriormente no item sobre as características de uma pesquisa de cunho qualitativo. Utilizou-se uma lista de tópicos ou grandes áreas relativos ao assunto objeto do estudo. Os respondentes fizeram seus comentários, com suas próprias palavras, sobre uma série de questões abertas, obtendo-se, assim, o entendimento dos entrevistados, que constituiu os dados qualitativos primários do estudo. 
$\mathrm{Na}$ estruturação do roteiro de pesquisa, levou-se em consideração, também, a experiência vivenciada pela pesquisadora, a acompanhar o trabalho desenvolvido por profissionais competentes e atuantes em institutos especializados nas áreas de pesquisa de mercado sobre o comportamento do consumidor.

$\mathrm{O}$ roteiro de entrevista foi submetido à realização de um teste piloto. Foram feitos alguns ajustes na terminologia empregada no documento submetido ao teste com os consumidores norte-americanos. A adoção desse procedimento permitiu o aprimoramento da estrutura do roteiro, bem como permitiu assegurar a validade das informações que foram levantadas, a partir do conjunto de questões formuladas. Tomou-se o cuidado de obter um grupo de respondentes que apresentasse o mesmo perfil do público-alvo da pesquisa, pois assim, assegurou-se a relevância das questões revistas pela pesquisadora. Cabe ressaltar que após a revisão analítica do instrumento, foi realizado o "back translation" do documento.

Com esse procedimento, de acordo com Berent apud Spínola (1995), buscou-se assegurar, o máximo possivel, de correspondência (tradução "fiel" dos termos) na linguagem empregada, para que não fosse perdido seu significado, permitisse identificar nuances no padrão de consumo e uso; possibilitasse a identificação dos critérios de avaliação em relação aos bens de consumo e os processos de tomada de decisão, bem como permitisse o reconhecimento do grau de desenvolvimento das sociedades foco do estudo comparado. Em virtude de fatores culturais peculiares de cada sociedade, ressalta-se o cuidado que a pesquisadora tomou ao elaborar o instrumento de coleta de dados.

Com a aplicação desse instrumento de pesquisa, foram reconhecidas as percepções, os sentimentos, as crenças e as motivações que, de alguma forma, exerceram influência sobre o comportamento de compra do consumidor e que ocorrem através das funções e papéis desempenhados pela embalagem de alimentos. A partir do conjunto informativo inserido no rótulo das embalagens de alimentos, foi possivel identificar o procedimento de tomada de decisão estabelecido pelo indivíduo durante o processo de comercialização dos gêneros alimentícios da categoria de cereais matinais.

Nesse sentido, os consumidores entrevistados discriminaram um conjunto de atributos característicos para essa categoria de produtos, que foram posteriormente ordenados segundo a preferência dos entrevistados. A ordenação desses atributos com características simultâneas do produto e atribuídos individualmente, bem como o reconhecimento de outros possiveis atributos sob a ótica do consumidor foram avaliados e comparados entre os dois grupos de respondentes dos paises integrantes da pesquisa de campo.

Por se tratar de uma pesquisa internacional comparada, a pesquisadora, como método auxiliar, gravou todas as entrevistas realizadas com os agentes brasileiros e norte-americanos de consumo e produção. Assim, a transcrição e o esclarecimento de dúvidas existentes acerca das informações coletadas nos Estados Unidos foram feitos em seu país de origem. 
Em linhas gerais, o roteiro para a realização das entrevistas com os consumidores brasileiros e norte-americanos (Apêndice 3) abordou os aspectos especificados no Quadro 3.5.

Na segunda etapa da pesquisa, foi utilizado o modelo sistêmico (Castro, 1994) desenvolvido pela pesquisadora, durante a realização das entrevistas com os agentes produtores (brasileiros e norteamericanos) de cereais matinais.

Para a definição da empresa produtora de cereais, levou-se em consideração os dados secundários decorrentes do trabalho desenvolvido anualmente por duas firmas (Nielsen, 1998 e Information Resources, Inc., 1998) de consultoria especializadas em analisar a participação das empresas no mercado de consumo.

Cabe ressaltar que a pesquisadora ao tomar a definição por uma única empresa não visou, portanto, a desenvolver um estudo de caso entre empresas produtoras de cereais. A estratégia adotada, levando-se em consideração ser o estudo de caráter exploratório, procurou caracterizar o comportamento de compra dos consumidores brasileiros e norte-americanos em relação à categoria de cereais matinais, a partir do conteúdo informativo inserido nas referidas embalagens. Ao mesmo tempo, a realização do estudo buscou, por meio da apresentação do modelo sistêmico (Castro, 1994) aos agentes produtores de cereais, levantar informações que subsidiassem o processo de planejamento/ desenvolvimento das embalagens de cereais, estreitassem a comunicação entre produtores e consumidores, bem como trouxessem contribuições para o aprimoramento do modelo sistêmico existente. 
Quadro 3.5

Roteiro de entrevista - consumidor de cereais matinais

\begin{tabular}{|c|c|}
\hline ETAPAS DO ROTEIRO & ASPECTOS ABORDADOS \\
\hline 1. INTRODUÇÃO & $\begin{array}{l}\text { - apresentação do estudo e do pesquisador; explicação dos objetivos do } \\
\text { estudo; agradecimento pela colaboração do respondente. }\end{array}$ \\
\hline 2. FASE DE RAPPORT (Aquecimento) & - caracterizar o entendimento dos entrevistados, acerca dos cereais matinais. \\
\hline 3. CATEGORIA DE CEREAIS MATINAIS & $\begin{array}{l}\text { abordagem acerca dos gêneros alimentícios denominados cereais matinais; } \\
\text { motivos e razões que levam o consumidor a compor uma refeição que } \\
\text { inclua o consumo de cereais; levantar hábitos de consumo dos } \\
\text { entrevistados. }\end{array}$ \\
\hline $\begin{array}{l}\text { 4. CRITÉRIO DE ESCOLHA DE CEREAL MATINAL } \\
\text { 4.1. RELEVÂNICA DOS ATRIBUTOS }\end{array}$ & $\begin{array}{l}\text { esimular uma situação de tomada de decisão por parte dos entrevistados; } \\
\text { caracterizar a existência de um dado comportamento de compra; levantar os } \\
\text { aspectos determinantes para a categoria de cereais, que levam o consumidor } \\
\text { a adquirir ou não esse tipo de produto; utilização dos cinco grandes grupos } \\
\text { (estética, elementos essenciais, promocionais, educativos e conveniência) } \\
\text { constituintes da abordagem sistêmica desenvolvida pela pesquisadora; } \\
\text { identificar grupos de atributos valorizados pelo consumidor, bem como o } \\
\text { juízo de valor conferido aos atributos especificados pelos entrevistados. }\end{array}$ \\
\hline 5. CONHECIMENTO E HÁBITOS DE COMPRA E CONSUMO & $\begin{array}{l}\text { caracterizar o processo de tomada de decisão, ou seja, a forma como o } \\
\text { consumidor expressa o seu comportamento de compra e consumo acerca } \\
\text { dos cereais matinais. }\end{array}$ \\
\hline 6. PERCEPÇÃO DO CONCEITO DE PRODUTO & $\begin{array}{l}\text { - abordagem sobre as características do cereal matinal e dos consumidores } \\
\text { que compram e consomem esse tipo de gênero alimentício. }\end{array}$ \\
\hline 7. PERCEPÇÃO DE EMBALAGEM & $\begin{array}{l}\text { identificar o papel da embalagem, para o consumidor, no processo de } \\
\text { tomada de decisão pela compra ou não do cereal; entendimento do } \\
\text { respondente quanto à aplicação da abordagem sistêmica para a categoria de } \\
\text { cereais matinais. }\end{array}$ \\
\hline 8. EMBALAGEM IDEAL DE CEREAIS MATINAIS & $\begin{array}{l}\text { - identificar a necessidade ou não de reformulaç̃̃es no conteúdo informativo } \\
\text { existente nas embalagens de cereais matinais. }\end{array}$ \\
\hline 9. INFLUÊNCIA DO SAC NA EMBALAGEM & $\begin{array}{l}\text { caracterizar o papel do SAC e sua relevância para o consumidor de cereal } \\
\text { matinal. }\end{array}$ \\
\hline
\end{tabular}

Elaborado pela pesquisadora 
Para a viabilização das entrevistas com as empresas, na porção brasileira foi feito um contato telefônico, com o profissional responsável pela área de marketing e elaborada pela autora do presente estudo, uma carta de apresentação (Apêndice 4). No caso da porção norte-americana, durante o desenvolvimento da "Bolsa Sanduíche", a pesquisadora participou de eventos internacionais. Entre eles, cabe ressaltar o denominado Companheiros das Américas, realizado em Washington (novembro de 1998). Assim, a pesquisadora teve a oportunidade de conhecer Dr. Norman A. Brown, presidente emérito da Fundação W. K. Kellogg. Após o referido evento, foi enviada uma carta (Apêndice 4) endereçada ao vice-presidente da área de marketing da Kellogg Company expondo o assunto da presente tese de doutorado. Como resultado dos contatos efetuados, foi feita uma visita à Kellogg Company, em Michigan e, consequentemente, foram obtidos dados fundamentais com os profissionais - agentes de produção - para a consecução deste estudo.

Para esta etapa do estudo, o instrumento de coleta dos dados, também, foi submetido a um teste piloto. A pesquisadora adotou a estratégia de verificar a pertinência do instrumento de pesquisa, aplicando-o em profissionais ligados à area de embalagens. Novamente, cabe destacar que só após a apreciação dos especialistas no setor de embalagens, é que foi realizado o "back translation" do documento.

O desenvolvimento das entrevistas envolveu profissionais da área de marketing (porção brasileira) e de estruturação fisica e gráfica (porção norte-americana) das embalagens de cereais.

Para elaborar o roteiro de entrevista (Apêndice 3) voltado para as empresas, considerou-se um modelo aplicado para a obtenção de um sistema de informações na segmentação de mercado (Berrigan e Finkbeiner, 1992).

O Quadro 3.5a ilustra os aspectos abordados no instrumento de pesquisa e a Figura 3.5.1 reflete o entendimento da pesquisadora acerca de uma abordagem sistêmica para o desenvolvimento de embalagens de alimentos. O modelo sistêmico (Castro, 1994) empregado foi validado com a realização de um estudo de cunho acadêmcio - Dissertação de Mestrado - da pesquisadora em questão. 


\begin{tabular}{|c|c|}
\hline ETAPAS DO ROTEIRO & ASPECTOS ABORDADOS \\
\hline 1. CARACTERIZAÇÃO DA EMPRESA & $\begin{array}{l}\text { nome e endereço da empresa; ramo de atividade; ano de fundação; atuação } \\
\text { comercial; número de unidades e nome, departamento, cargo e experiência } \\
\text { do profissional entrevistado. }\end{array}$ \\
\hline 2. ESTRUTURA DA EMPRESA & 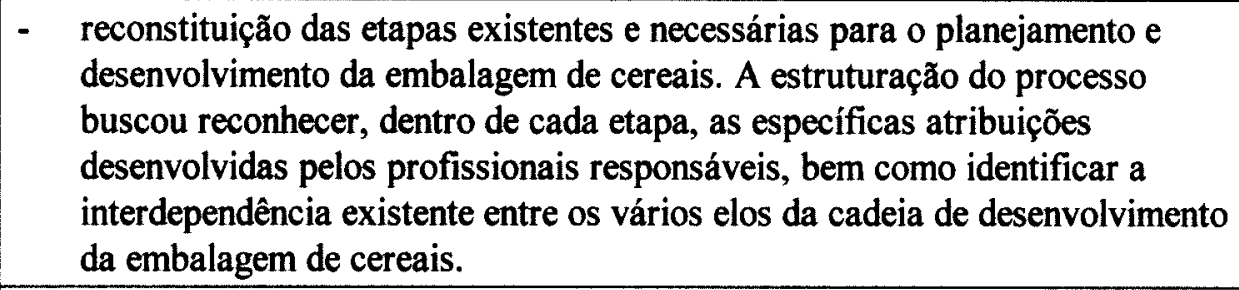 \\
\hline $\begin{array}{l}\text { 3. CATEGORIA DE CEREAIS MATINAIS } \\
\text { 3.1. DESENVOLVIMENTO DA EMBALAGEM }\end{array}$ & $\begin{array}{l}\text { - identificar os elementos básicos no processo de desenvolvimento da } \\
\text { embalagem de cereais matinais. }\end{array}$ \\
\hline 3.2. APECTOS CONCEITUAIS & $\begin{array}{l}\text { - identificar o papel da embalagem para a empresa; caracterizar a } \\
\text { comunicação estabelecida com o consumidor por intermédio do conjunto } \\
\text { informativo/ elementos visuais impressos na embalagem de cereais; } \\
\text { aplicacão da abordagem sistêmica e identificacão de grupos de informacões. }\end{array}$ \\
\hline 3.3. RELEVÂNICA DOS ATRIBUTOS & $\begin{array}{l}\text { - identificar grupos de atributos valorizados pela empresa e o juízo de valor } \\
\text { conferido aos atributos especificados pelo entrevistado. }\end{array}$ \\
\hline 3.4. COMUNICAÇÃO DA EMBALAGEM & $\begin{array}{l}\text { - identificar, no entendimento do produtor, características sócio-econômicas, } \\
\text { demográficas, bem como estilo de vida e hábitos dos consumidores de } \\
\text { cereais matinais. }\end{array}$ \\
\hline 4. CRITÉRIOS DE ESCOLHA DE CEREAIS MATINAIS & - identificar os critérios de escolha dos consumidores de cereais matinais. \\
\hline 5. CONHECIMENTO E HÁBITOS DE COMPRA E CONSUMO & $\begin{array}{l}\text { caracterizar, segundo o produtor, o processo de tomada de decisão, ou seja, } \\
\text { a forma como o consumidor expressa o seu comportamento de compra e } \\
\text { consumo acerca dos cereais matinais. }\end{array}$ \\
\hline 6. INFLUÊNCIA DO SAC NA EMBALAGEM & $\begin{array}{l}\text { - caracterizar o papel do SAC e sua relevância segundo o produtor de cereais } \\
\text { matinais. }\end{array}$ \\
\hline 7. EMBALAGEM IDEAL DE CEREAIS MATINAIS & $\begin{array}{l}\text { - reformulações no conteúdo informativo existente nas embalagens de cereais } \\
\text { matinais, a curto e médio prazo. }\end{array}$ \\
\hline
\end{tabular}

Elaborado pela pesquisadora 


\section{Embalagem de Alimentos}

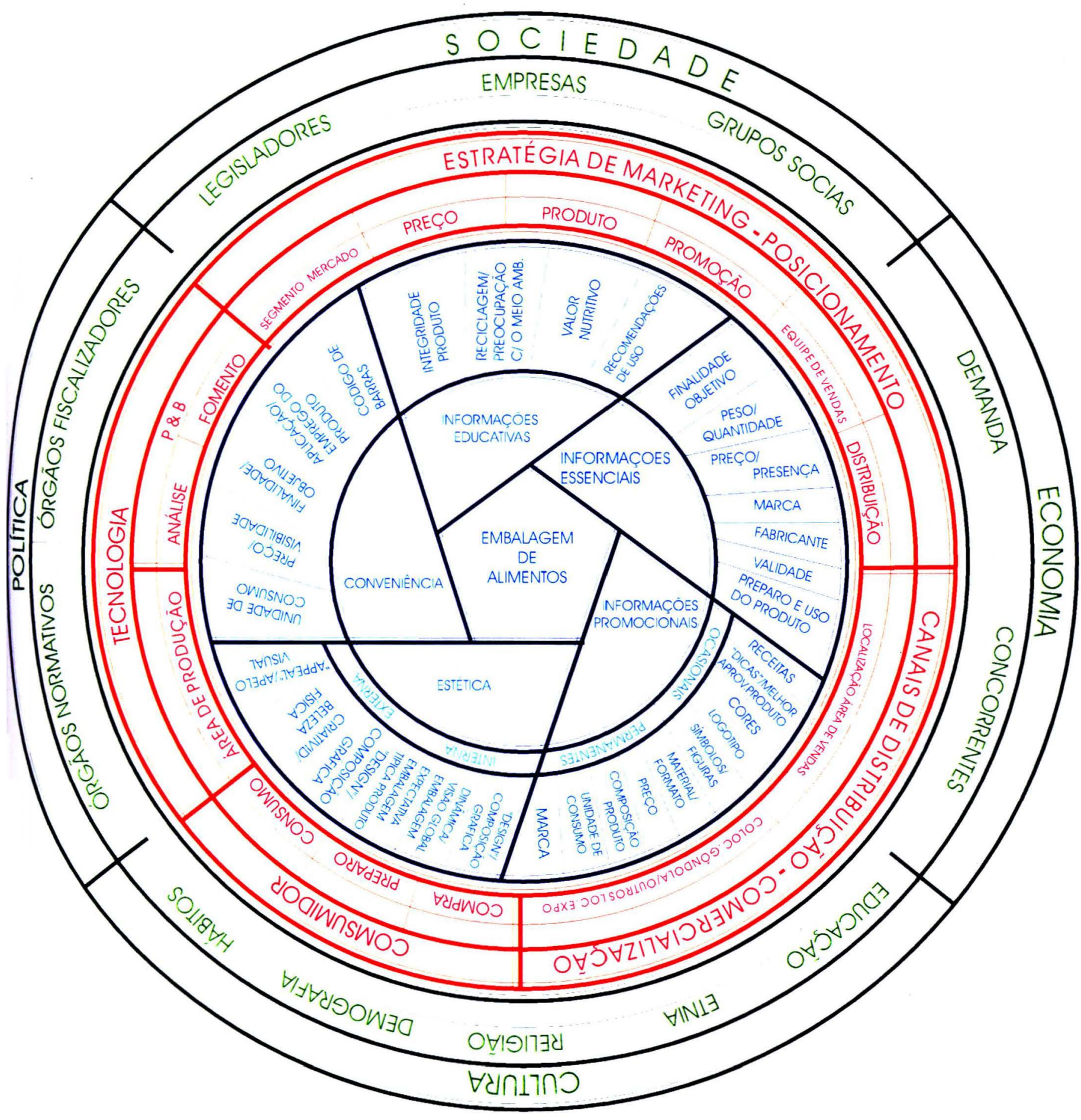

Figura 3.5.1 Modelo sistêmico

Fonte: Castro, 1994 


\section{$\Rightarrow$ Análise dos Dados}

De acordo com Hudson e Ozanne (1998), em uma pesquisa interpretativa, o pesquisador busca determinar motivos, significados, razões e outras experiências subjetivas que tem tempo e contexto determinados ("thick" descrição). Por essa razão, as particularidades do fenômeno adquirem maior importância, isto é, a meta do estudo é entender o comportamento e não predizê-lo.

A descrição da percepção das pessoas compreende a extensão/ profundidade dos detalhes contextuais obtidos pelo pesquisador. Inserido na realidade do contexto, as descobertas obtidas serão apresentadas levando-se em consideração critérios tais como idioma e terminologia das pessoas que estão sendo investigadas (Peñaloza, 1994).

Um instrumento subjetivo de avaliação/ mensuração suscita duas questões. A primeira, refere-se ao que tradicionalmente é chamado de validade interna das interpretações do pesquisador. A segunda, está relacionada a concepções tradicionais da validade externa do estudo. Em relação à primeira questão, a adoção do ciclo hermenêutico como um argumento pode fornecer suporte à validade interna em um estudo qualitativo (pesquisa interpretativa). Quanto à segunda questão, apesar do processo interpretativo ser subjetivo, não difere em espécie dos processos de validação que ocorre na ciência natural (Hirschman e Holbrook 1986, 1992). Portanto, quanto à validade externa da pesquisa, buscou-se estabelecer, de maneira apropriada, lógica similar a que é empregada nas ciências naturais na apresentação/ descrição das descobertas levantadas.

Segundo Tse, Belk e Zhou (1989), o uso da técnica Análise de Conteúdo tem emergido como um importante instrumento de pesquisa na área do comportamento do consumidor. Tal método tem sido explorado tanto em questões micro como macro. Quanto à perspectiva micro, os métodos analíticos de conteúdo têm sido aplicados para investigar a quantidade de informação disponibilizada pelos consumidores investigados. Ainda de acordo com os autores mencionados anteriormente, em uma perspectiva macro, esse método tem sido usado para investigar tendências sociais, tais como:

* as descrições do papel da mulher na sociedade (Whipple e Courtney, 1980);

* uso de imagens raciais em anúncios publicitários (Kassarjian, 1969);

- propagandas, que podem refletir características societais, por exemplo, como materialismo (Belk e Pollay, 1985);

* e propagandas relativas ao idoso (Gantz, Gartenberg e Rainbow, 1980).

Essas macro aplicações ilustram a utilidade da Análise de Conteúdo como instrumento de pesquisa que permite o entendimento dos valores de consumo através do tempo em diferentes culturas. 
A Análise de Conteúdo pode ser considerada uma análise científica no campo das comunicações. De acordo com Kassarjian (1977, p.10), análise de conteúdo é uma descrição cientifica, objetiva, sistemática, quantitativa e generalizável do conteúdo da comunicação. Essa técnica é uma medida não muito aplicada. Porém, seu emprego torna-se necessário quando a observação direta pode alterar o padrão de comportamento dos sujeitos objetos de estudo, ou ainda, quando o idioma e o modo de expressão dos respondentes são cruciais na investigação.

$\mathrm{Na}$ interpretação denominada densa ("thick") descrição dos dados levantados, o pesquisador busca refletir a realidade manifestada e inserida no fenômeno em estudo e não sua própria perspectiva, para que a reprodução dos dados seja assegurada. Portanto, o aspecto "confiança" é uma das características que distingue a Análise de Conteúdo quando comparada com outras técnicas de descrição de conteúdo comunicado em uma investigação científica.

A técnica Análise de Conteúdo compreende subdivisס̃es chamadas de unidades de análise. Dentre essas unidades de mensuração, empregou-se a palavra como unidade de medida. Através da palavra, a pesquisadora buscou descrever o entendimento dos consumidores entrevistados acerca do conteúdo informativo das embalagens de alimentos, mais especificamente as de cereais.

A referida técnica foi aplicada no estágio relacionado à interpretação e transcrição dos dados obtidos, permitindo a estruturação de um quadro referencial para apresentar os dados levantados com as entrevistas em profundidade. Na estruturação do quadro referencial, levou-se em consideração características sociais, culturais e ambientais. Tais características ajudaram a pesquisadora a identificar diferenças e similaridades no comportamento externado pelos consumidores brasileiros e norte-americanos entrevistados, durante o estabelecimento de suas práticas comerciais. Esse procedimento auxiliou, também, na identificação de atributos extraídos do conteúdo informativo inserido nas embalagens de cereais matinais, os quais, segundo uma sequência ordenada pelo grau de preferência dos entrevistados, acabam influenciando o comportamento do consumidor em sua tomada de decisão pela compra ou não do gênero alimentício.

\subsection{Aspectos Sumarizadores}

A presente pesquisa abordou o conteúdo informativo das embalagens de alimentos. O aprofundamento do conhecimento comparado sobre o processo de tomada de decisão, segundo a ótica brasileira e norte-americana dos agentes de consumo (aquisição ou não de um gênero alimentício) e produção (ações segundo as exigências do mercado consumidor), poderá representar um dos pontos de partida para a segmentação de mercados, conquista de novos e específicos centros convergentes de operações comerciais, bem como contribuir para a aplicação de um conjunto de medidas alternativas e direcionadas para o atendimento das necessidades do mercado de consumo e, sobretudo, para a preservação da competitividade das empresas. 
CAPÍTULO 4

RESULTADOS E ANÁLISES 


\section{RESULTADOS E ANÁLISES}

Conforme exposto anteriormente, em ambos os países (Brasil e Estados Unidos), o tamanho da amostra manteve-se constante, ou seja, sendo realizadas cinquenta entrevistas com cada grupo de consumidores brasileiros e norte-americanos de cereais matinais, perfazendo um total de cem entrevistas.

Utilizou-se a técnica de análise de conteúdo como respaldo para os comentários elaborados. Dentre as unidades de análise e mensuração que compreendem a referida técnica, empregou-se a palavra como unidade de medida. Através da palavra, a pesquisadora buscou descrever o entendimento dos consumidores entrevistados acerca do conteúdo informativo das embalagens de alimentos, mais especificamente, as de cereais matinais. Parte dos dados foram analisados utilizando-se o software estatístico "Statistical Package for the Social Science - SPSS".

Essa técnica foi aplicada no estágio relacionado à interpretação e transcrição dos dados obtidos, permitindo a estruturação de um quadro referencial para apresentar os dados levantados com as entrevistas em profundidade. Na estruturação do quadro referencial, levou-se em consideração características sociais, culturais e ambientais. Tais características ajudaram a pesquisadora a identificar diferenças e similaridades no comportamento externado pelos consumidores brasileiros e norte-americanos entrevistados, durante experiências vivenciadas com o produto objeto deste estudo. Esse procedimento auxiliou, também, na identificação de atributos extraídos do conteúdo informativo inserido nas embalagens de cereais matinais, os quais, segundo uma sequência ordenada pelo grau de preferência dos entrevistados, acabam influenciando o comportamento do consumidor em sua tomada de decisão pela compra ou não do gênero alimentício em questão.

Sendo um estudo de caráter exploratório, as informações levantadas representam uma interpretativa descrição quanto à ótica brasileira e norte-americana dos agentes de produção e consumo acerca das embalagens de cereais matinais. A seguir, com maior detalhamento, serão apresentados os resultados relativos aos dois grupos de consumidores entrevistados.

Para efeito de análise, a cada questão do roteiro de entrevista voltado para o consumidor, procedeu-se da seguinte maneira:

- nas tabelas estruturadas, as colunas com valores absolutos (ABS.) indicam o cômputo total dos resultados obtidos para cada conjunto de cinquenta consumidores entrevistados;

- as demais colunas apresentam os resultados totais segmentados pelas variáveis idade e renda. $O$ objetivo de segmentar os resultados foi o de poder verificar se o entendimento dos consumidores acerca da embalagem de cereais matinais poderia evidenciar alguma relação com essas variáveis. 
Cada variável independente foi segmentada em dois grupos, de acordo com o seguinte critério:

- idade: a faixa etária dos consumidores entrevistados compreendeu dois intervalos. No primeiro, encontram-se os consumidores na faixa de idade entre 18 a 35 anos. Os consumidores pertencentes ao segundo intervalo, enquadram-se na faixa entre 36 a 50 anos.

- renda: adotou-se a moeda norte-americana (dólar) como medida monetária, com o objetivo de estabelecer uma mensuração equiparada dos valores obtidos para a renda individual anual dos respondentes brasileiros e norte-americanos. Dessa forma, os entrevistados foram enquadrados em um dos seguintes intervalos - inferior a US\$25 mil ou igual/ superior a US\$25 mil.

As tabelas apresentam o percentual de respondentes que citaram o atributo sob apreciação no presente estudo. Quando o atributo não foi declarado por todos os entrevistados, a tabela sofreu um desmembramento, visando a identificar eventuais diferenças ao se analisá-lo por faixa etária e renda individual anual. Julgou-se conveniente, também, destacar os valores (negrito e/ou sombreado) inseridos nas tabelas com o objetivo de realçar o surgimento de eventuais diferenças em cada uma das variáveis independentes anteriormente relacionadas. Todas as vezes em que, no texto, aparecer a sigla "EUA", esta estará substituindo o nome referente ao país Estados Unidos da América.

A apresentação dos resultados está baseada nas seguintes etapas:

- Descrição da Amostra, a partir das variáveis independentes denominadas faixa etária e renda individual anual.

\section{* Resultados da Pesquisa}

- Análise do Produto - obtenção do entendimento mais amplo dos consumidores acerca da embalagem de cereais matinais. Num primeiro momento e de maneira geral, buscou-se uma visão mais detalhada dos entrevistados acerca do produto em questão, com a identificação de questões envolvendo aspectos de:

- caracterização do cereal matinal;

- papel/ função do produto;

* identificação de elementos positivos/ negativos;

* caracterização do perfil sócio-econômico do consumidor de cereais matinais.

- Análise da Embalagem - a partir do entendimento dos respondentes sobre o produto cereal matinal, a pesquisadora obteve mais subsídios para proceder às indagações referentes, especificamente, à embalagem de cereais matinais (Apêndice 5). Nessa etapa do estudo foram identificados os seguintes aspectos:

* conjunto de "informações lembradas", ou seja, presentes na memória dos entrevistados;

* papel/ função da embalagem de cereal matinal;

- facilidade/ dificuldade em encontrar as informações impressas na embalagem do produto;

- adequação/ inadequação da informação nutricional impressa na embalagem do cereal matinal; 
- conceituação de "embalagem ideal" para a categoria de cereais matinais;

- papel/ função do Serviço de Atendimento ao Consumidor - SAC, em relação à embalagem do produto

- Análise da Visão Sistêmica - obtenção do entendimento mais amplo dos consumidores sobre a embalagem de cereais matinais e sua influência no processo de tomada de decisão pela compra ou não desse gênero alimentício. Nesse sentido, foram destacados aspectos que envolvem a relevância de atributos a partir do conjunto informativo inserido na embalagem do produto.

\subsection{Descrição da Amostra}

Tabela 4.1a - Faixa Etária

\begin{tabular}{c|c|c|c|c}
\hline \multirow{2}{*}{ FAIXA ETÁRIA } & \multicolumn{2}{|c|}{ EUA } & \multicolumn{2}{c}{ BRASIL } \\
\cline { 2 - 5 } & ABS. & $\%$ & ABS. & $\%$ \\
\hline de 18 a 35 anos & 23 & 46,0 & 26 & 52,0 \\
\hline de 36 a 50 anos & 27 & 54,0 & 24 & 48,0 \\
\hline TOTAL & 50 & 100,0 & 50 & 100,0 \\
\hline
\end{tabular}

Tabela 4.1b - Renda Individual Anual

\begin{tabular}{c|c|c|c|c}
\hline RENDA INDIVIDUAL & \multicolumn{2}{|c|}{ EUA } & \multicolumn{2}{c}{ BRASIL } \\
\cline { 2 - 5 } ANUAL (US\$) & ABS. & $\%$ & ABS. & $\%$ \\
\hline até $25 \mathrm{mil}$ & 24 & 48,0 & 26 & 52,0 \\
\hline$+25 \mathrm{mil}$ & 26 & 52,0 & 24 & 48,0 \\
\hline TOTAL & 50 & 100,0 & 50 & 100,0 \\
\hline
\end{tabular}

Pelas Tabelas 4.1a e 4.1b, verifica-se que houve uma distribuição equilibrada do número de respondentes ao se considerar a faixa etária e renda individual anual.

\subsection{Análise do Produto}

\subsubsection{Entendimento dos respondentes sobre o conceito "alimento"}

Como a questão era aberta, os entrevistados podiam citar mais de um aspecto relacionado ao termo "alimento". De acordo com a Tabela 4.2.1, as declarações dadas pelos entrevistados foram interpretadas como "conceituação" pertinente ao termo "alimento". Assim, todos os entrevistados, no Brasil e nos EUA, citaram aspectos relativos à "importância" do cereal matinal. Além disso, os entrevistados brasileiros informaram, também, elementos sobre "aspecto funcional" $(42,0 \%) \mathrm{e}$ "poder de saciedade" $(30,0 \%)$.

\section{importância}

Todos os entrevistados reconheceram que o conceito "alimento" pode ser aplicado para o item cereal matinal. Essa transposição de conceito ocorre pois, segundo os entrevistados, o cereal matinal é visto como um gênero alimentício que apresenta "importância" pela sua composição nutricional (vitaminas, minerais, isento de colesterol) e seu consumo pode substituir uma refeição (desjejum, almoço, lanche, jantar). O cereal matinal é visto como um dos itens integrantes na formação dos grupos de alimentos (energético, construtor, repositor) da "Pirâmide Alimentar". 
Tabela 4.2.1 Entendimento do conceito "alimento" (valores em porcentagem)

\begin{tabular}{|c|c|c|}
\hline $\begin{array}{l}\text { Declararam aspectos } \\
\text { relacionados com: }\end{array}$ & EUA & BRASIL \\
\hline Importância & 100,0 & 100,0 \\
\hline $\begin{array}{l}\text { Aspecto funcional } \\
\text { Sem menção }\end{array}$ & 0 & $\begin{array}{l}42,0 \\
58,0 \\
\end{array}$ \\
\hline $\begin{array}{l}\text { Poder de saciedade } \\
\text { Sem menção }\end{array}$ & 0 & $\begin{array}{l}30,0 \\
70,0\end{array}$ \\
\hline Base & 50 & 50 \\
\hline
\end{tabular}

\begin{tabular}{c|c|c|c|c|c}
\hline \multirow{2}{*}{$\begin{array}{c}\text { Deciararam aspectos } \\
\text { relacionados com: }\end{array}$} & RESP. & $\begin{array}{c}\text { FAIXA ETÁRIA } \\
\text { (anos) }\end{array}$ & \multicolumn{2}{|c}{$\begin{array}{c}\text { RENDA IND.ANUAL } \\
\text { (USS) }\end{array}$} \\
\cline { 2 - 6 } & BR & $18-35$ & $36-50$ & $<25$ mil & $\geq 25$ mil \\
\hline Aspecto funcional & 42,0 & 42,3 & 41,7 & 42,3 & 41,7 \\
Sem mençăo & 58,0 & 57,7 & 58,3 & 57,7 & 58,3 \\
\hline Base & 50 & 26 & 24 & 26 & 24 \\
Poder de saciedade & 30,0 & 37,0 & 21,7 & 15,4 & 45,8 \\
Sem mençăo & 70,0 & 63,0 & 78,3 & 84,6 & 54,2 \\
\hline Base & 50 & 27 & 23 & 26 & 24 \\
\hline
\end{tabular}

\section{aspecto funcional}

Para os consumidores brasileiros, também é atribuido ao cereal matinal o conceito "alimento" pelo seu aspecto "funcional". O consumo do produto propicia a regularização do funcionamento do aparelho digestivo e, consequentemente, a limpeza do organismo. Houve uma distribuição equitativa, no que se refere à idade e ao poder aquisitivo dos respondentes brasileiros. Não se evidencia significativa diferença na concentração das respostas em termos da idade e/ou do poder aquisitivo dos entrevistados brasileiros.

\section{poder de saciedade}

Ainda, segundo o entendimento dos entrevistados brasileiros, a "fibra" presente no cereal proporciona "poder de saciedade", ou seja, sua ingestão evita que o indivíduo sinta fome no espaço de tempo entre uma refeição e outra. Verifica-se uma maior concentração das respostas na faixa etária de até 35 anos $(37,0 \%)$ e verificando-se renda individual anual superior a 25 mil $(45,8 \%)$.

\subsubsection{Entendimento dos respondentes acerca do conceito "cereal matinal"}

Conforme a Tabela 4.2.2, as declarações dadas pelos entrevistados foram interpretadas como "conceituação" pertinente ao cereal matinal. Como a questão era aberta, os respondentes podiam citar mais de um aspecto relacionado ao produto. Dessa maneira, todos citaram aspectos referentes à "caracterização" de cereal matinal. Além disso, todos informaram, também, aspectos sobre os "beneficios/ aplicação" e "diversidade de consumo". Quanto ao item "embalagem", 68,0\% dos norte-americanos fizeram algumas declarações. No Brasil, a proporção foi de $52,0 \%$. 
Tabela 4.2.2 Entendimento do conceito "cereal matinal" (valores em porcentagem)

\begin{tabular}{c|c|c}
\hline $\begin{array}{c}\text { Dectararam aspectos } \\
\text { rdacionados com }\end{array}$ & EUA & BRASIL \\
\hline Caracterização & 100,0 & 100,0 \\
\hline Beneficios/aplicaça & 100,0 & 100,0 \\
\hline $\begin{array}{c}\text { Diversidade de } \\
\text { consumo }\end{array}$ & 100,0 & 100,0 \\
\hline Embalagem & 68,0 & 52,0 \\
& 32,0 & 48,0 \\
\hline Base & 50 & 50 \\
\hline
\end{tabular}

\begin{tabular}{c|c|c|c|c|c|c|c|c|c|c|c}
\hline & \multirow{2}{*}{} & \multicolumn{4}{|c|}{ FALXA ETÁRIA } & \multicolumn{3}{c|}{ RENDA INDIV. ANUAL } \\
\cline { 3 - 11 } & RESPOND. & \multicolumn{2}{|c|}{$18-35$ anos } & \multicolumn{2}{|c|}{$36-50$ anos } & \multicolumn{2}{c|}{$<25$ mil } & \multicolumn{2}{c}{$\geq 25$ mil } \\
\hline $\begin{array}{c}\text { Declararam aspectos } \\
\text { relacionados com }\end{array}$ & EUA & BR & EUA & BR & EUA & BR & EUA & BR & EUA & BR \\
\hline Embalagem & 68,0 & 52,0 & 74,0 & 68,0 & 63,0 & 36,0 & 60,0 & 42,0 & 76,0 & 63,0 \\
& 32,0 & 48,0 & 26,0 & 32,0 & 37,0 & 64,0 & 40,0 & 58,0 & 24,0 & 37,0 \\
\hline Base & 50 & 50 & 23 & 25 & 27 & 25 & 25 & 26 & 25 & 24 \\
\hline
\end{tabular}

\section{caracterização}

Todos os entrevistados caracterizaram o cereal matinal como um produto processado, desidratado, oriundo de diversos grãos (milho, trigo, cevada, arroz), podendo ser adicionado a ele, ou não, na fase de seu processamento, frutas desidratadas (de acordo com o hábito alimentar de cada país onde se desenvolveu o estudo), tais como maçã, uva-passa, banana-passa, tâmaras, framboesas, coco, entre outras, bem como a adição de castanhas, amêndoas, açúcar e mel.

Segundo os respondentes norte-americanos, o cereal matinal é considerado um produto "básico" na alimentação diária da familia norte-americana. $\mathrm{O}$ conjunto de ingredientes que compõe $\mathrm{o}$ item alimentício, de acordo com esses entrevistados, torna o produto "saudável" ao consumidor. Em virtude da diversidade de cereais ofertados (marcas, categorias) pelo mercado norte-americano, os entrevistados ressaltaram a variedade de forma/ formato existente na comercialização do referido produto, como por exemplo, flocos, bastonetes, bolinhas, conchinhas, entre outros. Para os consumidores brasileiros, de maneira geral, o produto comercializado na forma de "flocos" caracteriza/ representa a aparência fisica do cerereal matinal.

Em termos de sabor, os dois grupos de entrevistados enfatizaram que o sabor natural do produto pode ser considerado "neutro" ou "amargo". Este último ocorre, quando predomina na sua composição a presença de grãos provenientes da aveia e/ou do trigo. Por outro lado, seu sabor é considerado "adocicado" por causa da incorporação de açúcar ou mel, bem como das frutas desidratadas. O cereal matinal foi, ainda, considerado um produto atrativo para o consumo pelo seu lado "lúdico", isto é, o consumidor descontraidamente e prazeirosamente degusta um produto que, além de alimentar é saboroso (adocicado e crocante).

\section{benefícios/ aplicação}

Quanto aos "beneficios/ aplicação" do cereal matinal, todos os entrevistados destacaram o aspecto "praticidade/ rapidez". O produto propicia uma alimentação saudável e não requer que o consumidor dedique muito do seu tempo para prepará-lo e consumi-lo. Os consumidores aliaram ao aspecto "praticidade/ rapidez" o fator "saciedade". De acordo com os dois grupos de respondentes, o cereal matinal é considerado um "produto ideal" para quem quer estar bem alimentado, ou seja, "ingerir um alimento que não pese no estômago, mate a fome e, ao mesmo tempo, sustente e confira energia ao individuo por um bom espaço de tempo". 


\section{diversidade de consumo}

Em relação ao atributo "diversidade de consumo", o cereal matinal, de maneira geral, é consumido/ ingerido pelos entrevistados brasileiros e norte-americanos a qualquer hora do dia. Para os respondentes norte-americanos ficou patente a relevância do emprego desse produto como primeira refeição do dia. Tradicionalmente, no desdejum, eles adicionam leite ao cereal. $O$ produto também é muito utilizado no momento de fazer uma refeição considerada mais leve, isto é, um lanche à tarde (em casa, na escola, no trabalho) ou à noite.

No Brasil, os entrevistados destacaram o consumo do cereal matinal como um "snack", ou seja, um petisco adocicado ingerido numa hora de lazer, como por exemplo, enquanto o consumidor assiste a um programa de televisão. $O$ produto pode ser consumido na temperatura quente e/ou fria. Ainda, segundo o hábito alimentar dos respondentes brasileiros, normalmente, é adicionado ao cereal leite, sucos de frutas, iogurte, ou sorvete.

Para os entrevistados brasileiros e norte-americanos, o cereal denominado "Corn Flakes" tem sido utilizado como um ingrediente em preparações culinárias, como por exemplo, saladas, empanados, massa de tortas. O produto "Rice Krispies" é muito empregado pelo consumidor norte-americano no preparo de um docinho de mesmo nome. No Brasil, conforme ressaltaram os entrevistados, o produto pertencente à categoria denominada "crespinhos de arroz" entra na elaboração de bombons. Outro produto destacado por este último grupo de respondentes foi a "aveia". Esse cereal tem integrado a lista de ingredientes no preparo de bolos, biscoitos/ bolachinhas, sopas, entre outros.

\section{embalagem}

Os norte-americanos da faixa etária compreendida entre 18 a 35 anos tenderam a citar mais elementos relacionados com a embalagem $(74,0 \%)$ do que aqueles classificados na outra faixa (63\%). Dentre os brasileiros, a tendência foi a mesma, mas com uma diferença muito mais acentuada.

Para ambos os grupos de consumidores entrevistados, a embalagem de cereais matinais facilita na identificação do produto por apresentar um colorido vibrante e atraente típicos de cada marca ofertada nos pontos-de-venda, bem como por trazer foto de personagens e do próprio produto ('tigela com o cereal, leite, mel, frutas") na face principal do cartucho. Além disso, o material, forma/ formato e tamanho dos cartuchos e sacos plásticos tornam padronizada a comercialização dos cereais matinais.

\subsubsection{Entendimento dos respondentes acerca do conceito "cereais matinais" para as marcas compradas e consumidas}

Nesta questão do roteiro de entrevista, procurou-se identificar possíveis variações quanto ao entendimento dos entrevistados acerca do conceito "cereal matinal", quando fossem especificados os tipos e as marcas desse produto adquiridos e consumidos pelos entrevistados. 
Conforme mostra a Tabela 4.2.3, cabe ressaltar que existem algumas peculiaridades, em termos de linhas de produto e marcas ofertadas, tanto no mercado consumidor brasileiro como no norteamericano. Nos EUA, verifica-se uma concentração das respostas, em torno de $65,0 \%$ a $70,0 \%$, para as categorias de cereais denominadas "Puffs" e "Cherrios" e flocos de milho ("Corn Flakes", "Frosted Flakes"). Em relação ao cereais denominados integrais da marca "Raisin Bran", apenas $32,0 \%$ dos respondentes norte-americanos declararam comprar e consumir esse tipo de produto. Quanto ao Brasil, o cereal "Aveia" foi mencionado por $58,0 \%$ do total de respondentes. Observase, ainda, que o item "marcas em geral" foi declarada por $42,0 \%$ desses entrevistados. Excepcionalmente, as categorias "Muesli" e "Granola" foram citadas por 58,0\% dos entrevistados brasileiros e por, apenas, $30,0 \%$ dos respondentes norte-americanos.

\section{"Puffs" e "Cherrios"}

A linha de cereais matinais denominada "Puffs" e "Cherrios" é constituída por inúmeros produtos que apresentam uma característica básica. São cereais aerados, isto é, predomina o formato esférico e são "ocos" no seu interior. Alguns são cobertos com uma camada glaceada de açúcar, apresentam sabor "bem adocicado", possuem elevado teor de fibra, bem como consistência crocante mais prolongada (não murcham com facilidade quando adicionados ao leite), maciez e leveza. Existe, também, uma diversidade de sabores, como maçã com canela, coco, "cookie", chocolate, frutas, manteiga de amendoim, ou ainda, a combinação entre si (ou não) de variados grãos, como milho, arroz, trigo, entre outros, que misturados às frutas apresentam um agradável sabor adocicado. Verifica-se uma maior concentração das respostas na faixa etária de até 35 anos $(79,0 \%)$. Quanto à renda individual anual, as respostas concentraram-se na faixa de menor poder aquisitivo $(73,0 \%)$.

\section{"Corn Flakes" e "Frosted Flakes"}

Em relação aos produtos denominados "Corn Flakes" e "Frosted Flakes" ("Sucrilhos", no Brasil), a principal diferença levantada pelos entrevistados norte-americanos vem a ser o teor de açúcar, bem mais elevado no cereal da marca "Frosted Flakes". Consequentemente, mencionaram ser um produto mais apreciado e consumido pelo público infantil, quando comparado com o denominado "Corn Flakes". Ambos os produtos foram conceituados como cereal "básico", ou seja, simples. O grão de milho é o item principal/ básico em sua composição. Ainda, segundo os norte-americanos, esses dois tipos de cereais matinais possuem um baixo grau de industrialização/ processamento do que as demais categorias do produto. Por isso, foram denominados produtos "naturais". Observase uma maior concentração das respostas na faixa etária entre 36 a 50 anos $(68,0 \%)$. Quanto à renda individual anual, as respostas concentraram-se na faixa de menor poder aquisitivo $(78,0 \%)$.

\section{"Raisin Bran"}

O produto "Raisin Bran" segundo os entrevistados norte-americanos foi inserido na classificação de um cereal sem um processamento rebuscado (produto "natural"), visto ser composto, apenas, de flocos de trigo integral e de uva-passas desidratadas. Foi destacada a agradável mistura do sabor adocicado da uva-passa com o do grão integral do trigo. Os respondentes ressaltaram, ainda, o fato do produto ser levemente "crespinho", de longa consistência crocante, bem como propiciar uma alimentação saudável, visto ser constituído de trigo integral. Constata-se uma maior concentração 
das respostas na faixa etária de até 35 anos $(42,0 \%)$. Quanto à renda individual anual, as respostas concentraram-se na faixa de menor poder aquisitivo $(35,0 \%)$.

Tabela 4.2.3 Quantidade de respondentes que declararam o conceito "cereais matinais" para as marcas compradas e consumidas (valores em porcentagem)

\begin{tabular}{|c|c|c|c|c|c|c|c|c|c|c|}
\hline \multirow{3}{*}{ MARCAS } & \multicolumn{2}{|c|}{ RESPONDENTES. } & \multicolumn{4}{|c|}{ FAIXA ETÁRIA } & \multicolumn{4}{|c|}{ RENDA INDIV. ANUAL - USS } \\
\hline & \multirow[t]{2}{*}{ EUA } & \multirow[t]{2}{*}{ BRASIL } & \multicolumn{2}{|c|}{$18-35$ anos } & \multicolumn{2}{|c|}{$36-50$ anos } & \multicolumn{2}{|c|}{$<25 \mathrm{mil}$} & \multicolumn{2}{|c|}{$\geq 25 \mathrm{mil}$} \\
\hline & & & EUA & BR & EUA & BR & EUA & BR & EUA & BR \\
\hline Puffs e Cherrios & 68,0 & $\mathbf{0}$ & 79,0 & $\overline{0}$ & 58,0 & $\overline{0}$ & 73,0 & $\mathbf{0}$ & 62,5 & $\mathbf{0}$ \\
\hline Sem menções & 32,0 & $\mathbf{0}$ & 21,0 & 0 & 42,0 & 0 & 27,0 & $\mathbf{0}$ & 37,5 & $\mathbf{0}$ \\
\hline Base & 50 & 0 & 24 & 0 & 26 & 0 & 26 & 0 & 24 & 0 \\
\hline Corn F. e Frosted Flakes & 66,0 & 0 & 64,0 & 0 & 68,0 & 0 & 78,0 & 0 & 52,0 & 0 \\
\hline Sem menções & 34,0 & 0 & 36,0 & 0 & 32,0 & $\begin{array}{l}0 \\
0\end{array}$ & 22,0 & 0 & 48,0 & 0 \\
\hline Base & 50 & $\mathbf{0}$ & 25 & 0 & 25 & 0 & 27 & 0 & 23 & 0 \\
\hline Raisin Bran & 32,0 & 0 & 42,0 & 0 & 23,0 & 0 & 35,0 & 0 & 29,0 & 0 \\
\hline Sem menções & 68,0 & 0 & 58,0 & 0 & 77,0 & 0 & 65,0 & $\mathbf{0}$ & 71,0 & $\mathbf{0}$ \\
\hline Base & 50 & 0 & 24 & 0 & 26 & 0 & 26 & 0 & 24 & 0 \\
\hline Aveia & 0 & 58,0 & 0 & 52,0 & 0 & 64,0 & $\mathbf{0}$ & 62,0 & 0 & 52,0 \\
\hline Sem mençães & 0 & 42,0 & 0 & 48,0 & 0 & 36,0 & 0 & 38,0 & 0 & 48,0 \\
\hline Muesli e Granola & 30,0 & 58,0 & 33,0 & 52,0 & 27,0 & 64,0 & 19,0 & 62,0 & 42,0 & 52,0 \\
\hline Sem mençðes & 70,0 & 0 & 67,0 & 0 & 73,0 & 0 & 81,0 & 0 & 58,0 & 0 \\
\hline Marcas em geral & 0 & 42,0 & 0 & 48,0 & $\mathbf{0}$ & 36,0 & $\mathbf{0}$ & 38,0 & 0 & 48,0 \\
\hline Sem menç̃̃es & 56,0 & 0 & 56,0 & 0 & 57,0 & 0 & 46,0 & 0 & 65,0 & $\overline{0}$ \\
\hline Base & 50 & 50 & 27 & 25 & 23 & 25 & 24 & 29 & 26 & 21 \\
\hline
\end{tabular}

\section{“Aveia”}

Os entrevistados brasileiros ressaltaram que o cereal denominado "Aveia" levou-os a "uma viagem no tempo", isto é, fez com que eles recordassem da sua infância. É um periodo em que esse produto é, habitualmente, oferecido às crianças pelas suas mães na forma de mingaus e/ou vitaminas. A "Aveia" é comercializada na forma de flocos (mais finos, mais grossos) e de farinha. Foi considerado um produto nutritivo, rico em fibras, bem como com intenso emprego na culinária brasileira. Entra na preparação de bolos, biscoitos e/ou bolachinhas. Observa-se que essas características foram ressaltadas, principalmente, pelos respondentes na faixa etária entre 36 a 50 anos $(64,0 \%)$. Quanto à renda individual anual, houve uma maior concentração das respostas na faixa de menor poder aquisitivo $(62,0 \%)$.

\section{"Muesli" e "Granola"}

Segundo o entendimento dos entrevistados, o cereal "Muesli" foi descrito como um produto que:

- tem alto teor de fibra; 
- apresenta agradável sabor, levemente adocicado, proveniente da mistura de castanhas e/ou amêndoas às frutas desidratadas e aos grãos de trigo, aveia e cevada (no produto norteamericano);

- foi considerado saudável e nutritivo, em virtude da sua composição;

- possue consistência crocante.

Em relação ao cereal "Granola", os entrevistados destacaram as seguintes caracteristicas do produto:

- apresenta agradável sabor, acentuadamente adocicado, proveniente da mistura de frutas desidratadas, principalmente, uva-passas, tâmaras e da adição de mel à sua composição;

- variedade de grãos como trigo, milho, aveia e arroz (no produto brasileiro), que misturados ao mel originam grumos/ "clusters" crocantes e levemente "crespinhos";

- o conjunto textura ("crespinho"), consistência (crocante) e aparência de grumos/ "clusters" levam o consumidor a ingeri-lo, muitas vezes, como um petisco adocicado ("snack").

Com base no entendimento dos entrevistados, observa-se que a descrição atribuída a cada um dos cereais torna-os muito semelhantes. No geral, os entrevistados não percebem, claramente, as caracteristicas típicas de cada um deles. A "Granola" diferencia-se do "Muesli", principalmente, na formação dos grumos/ "clusters". É um produto de maior teor calórico, decorrente dos ingredientes presentes na sua composição.

Na Tabela 4.2.3, verifica-se, no Brasil, uma maior concentração das respostas na faixa etária entre 36 a 35 anos $(64,0 \%)$. Em relação à renda individual anual, as respostas concentraram-se na faixa de menor poder aquisitivo $(62,0 \%)$. Quanto aos entrevistados norte-americanos, observa-se uma inversão na concentração das respostas, ou seja, para o fator idade destaca-se a faixa etária de até 35 anos $(33,0 \%)$. Quanto à variável renda individual anual, as respostas concentraram-se na faixa de maior poder aquisitivo $(42,0 \%)$.

\section{marcas em geral}

Acredita-se que em função da reduzida gama de cereais matinais ofertados pelo mercado brasileiro em comparação com o do norte-americano, os respondentes brasileiros tenham verbalizado seu entendimento acerca dessa categoria de produtos de forma mais ampla, isto é, englobando as características básicas dos cereais sem fazer distinção de tipo, categoria, ou ainda, linha de cereais. Em relação às características básicas dos cereais matinais, cabe ressaltar os seguintes aspectos elencados pelos entrevistados brasileiros:

- sabor adocicado, gostoso e variado (chocolate, frutas, entre outros), consistência crocante;

- grãos processados e desidratados gerando "flocos", como forma convencional de apresentação do produto;

- nutritivo (vitaminas, minerais), saudável (baixo teor de colesterol e de gordura); 
- funcional - presença das fibras ajuda a regularizar o funcionamento do aparelho digestivo;

- poder de saciedade - conferir energia, sustentar, alimentar;

- praticidade no preparo e consumo.

De acordo com a Tabela 4.2.3, verifica-se, no Brasil, uma maior concentração das respostas na faixa etária de até 35 anos $(48,0 \%)$. Em relação à renda individual anual, as respostas concentraram-se na faixa de maior poder aquisitivo $(48,0 \%)$.

\subsubsection{Entendimento dos respondentes acerca do conceito "principal função do cereal matinal"}

De acordo com a Tabela 4.2.4, as declarações dadas pelos entrevistados foram interpretadas como principal função do cereal matinal. Como a questão era aberta, os entrevistados podiam citar mais de um aspecto relacionado ao cereal matinal. Assim, 52,0\% dos entrevistados brasileiros e 68,0\% dos norte-americanos citaram o fato de "iniciar o dia bem alimentado". Além disso, 82,0\% e 58,0\% dos respondentes, respectivamente no Brasil e nos EUA, informaram aspectos sobre o lado "saudável/ nutritivo" dos cereais matinais. Quanto ao item "outras funções, verifica-se que apenas os entrevistados brasileiros $(52,0 \%)$ fizeram menção a esse aspecto.

\section{começar bem o dia/ saciedade}

Segundo o entendimento dos entrevistados, o fato de "estar bem alimentado" e "fornecimento de energia" são aspectos que estão relacionados ao termo "saciedade". O emprego da expressão "to get your day" pelos respondentes norte-americanos, quer dizer "comece bem o seu dia", isto é, bem alimentado, com disposição e energia. Nos EUA, verifica-se uma maior concentração das respostas na faixa etária de até 35 anos $(71,0 \%)$. Quanto à renda individual anual, as respostas concentraram-se na faixa de maior poder aquisitivo $(75,0 \%)$. Em relação ao Brasil, observa-se que houve a mesma tendência de respostas. Elas se concentraram na faixa etária de até 35 anos $(54,5 \%)$ $\mathrm{e}$, no que diz respeito à renda individual anual, verifica-se uma concentração na faixa de maior poder aquisitivo $(71,0 \%)$.

\section{saudável/ nutritivo}

Para os entrevistados, o aspecto "saudável"/ "nutritivo" está relacionado à composição do cereal (vitaminas, minerais, baixo teor de gordura, sem colesterol), ao fornecimento de energia, bem como refere-se à presença de fibra, responsável pelo funcionamento regular do aparelho digestivo. Entre os brasileiros, verifica-se uma maior concentração das respostas na faixa etária entre 36 a 50 anos $(95,8 \%)$. Quanto à renda individual anual, as respostas concentraram-se na faixa de maior poder aquisitivo $(91,3 \%)$. Nos EUA, observa-se a mesma tendência nas respostas, ou seja, houve uma maior concentração delas na faixa etária entre 36 a 50 anos $(61,5 \%)$ e, em relação à renda individual anual, as respostas concentraram-se na faixa de maior poder aquisitivo $(78,3 \%)$. 
Tabela 4.2.4 Entendimento do conceito "principal função do cereal matinal" (valores em porcentagem)

\begin{tabular}{|c|c|c|c|c|c|c|c|c|c|c|}
\hline \multirow{3}{*}{ CITAÇÕES } & \multicolumn{2}{|c|}{ RESPOND. } & \multicolumn{4}{|c|}{ FAIXA ETÁRIA } & \multicolumn{4}{|c|}{ RENDA INDIV. ANUAL - US\$ } \\
\hline & \multirow[t]{2}{*}{ EUA } & \multirow[t]{2}{*}{ BRASIL } & \multicolumn{2}{|c|}{ 18-35 anos } & \multicolumn{2}{|c|}{$36-50$ anos } & \multicolumn{2}{|c|}{$<25 \mathrm{mil}$} & \multicolumn{2}{|c|}{$\geq 25 \mathrm{mil}$} \\
\hline & & & EUA & BR & EUA & BR & EUA & BR & EUA & BR \\
\hline "Comecar bem o dia"/saciedade & 68,0 & 52,0 & 71,0 & 54,5 & 65,4 & 50,0 & 61,5 & 34,6 & 75,0 & 71,0 \\
\hline Sem mençðes & 32,0 & 48,0 & 29,0 & 45,5 & 34,6 & 50,0 & 38,5 & 65,4 & 25,0 & 29,0 \\
\hline Base & 50 & 50 & 24 & 22 & 26 & 28 & 26 & 26 & 24 & 24 \\
\hline Saudável / nutritivo & 58,0 & 82,0 & 54,2 & 69,2 & 61,5 & 95,8 & 40,7 & 87,0 & 78,3 & 91,3 \\
\hline Sem menções & 42,0 & 18,0 & 45,8 & 30,8 & 38,5 & 4,2 & 59,3 & 13,0 & 21,7 & 8,7 \\
\hline Base & 50 & 50 & 24 & 26 & 26 & 24 & 27 & 27 & 23 & 23 \\
\hline Outras funç̋̃es & 0 & 52,0 & 0 & 54,0 & 0 & 50,0 & 0 & 59,2 & 0 & 38,5 \\
\hline Sem mençðes & 0 & 48,0 & 0 & 46,0 & 0 & 50,0 & 0 & 40,8 & 0 & 61,5 \\
\hline Base & 0 & 50 & 0 & 26 & 0 & 24 & 0 & 27 & 0 & 23 \\
\hline
\end{tabular}

\section{outras funções}

Como já foi, anteriormente, observado, o item "outras funções" foi mencionado só pelos consumidores brasileiros. Eles ressaltaram o aspecto "lúdico" no cereal matinal. Segundo esse grupo de entrevistados, além de ser um produto de sabor agradável (adocicado), seu consumo é feito de maneira divertida e prazeirosa. Enquanto a criança se diverte ao consumir o cereal, ela está, ao mesmo tempo, sendo alimentada. No momento em que o adulto está assistindo a um programa de televisão, o cereal é consumido como um petisco adocicado ("snack"), o que também representa uma forma divertida e prazeirosa de consumir o produto. Verifica-se que esse entendimento esteve mais concentrado na faixa etária de até 35 anos (54,0\%). Quanto à renda individual anual, as respostas concentraram-se na faixa de menor poder aquisitivo $(59,2 \%)$.

\subsubsection{Aspectos positivos e negativos no cereal matinal}

Com o objetivo de buscar melhor entendimento dos consumidores brasileiros e norte-americanos sobre o produto - cereal matinal, foi indagado aos entrevistados que aspectos positivos e/ou negativos poderiam ser identificados nesse gênero alimentício.

De acordo com os dados apresentados na Tabela 4.2.5, todos os entrevistados ressaltaram o fato de existirem aspectos positivos nos cereais matinais. Quanto à identficação de aspectos negativos no produto, a proporção de respostas $(58,0 \%)$ foi a mesma para os dois grupos de respondentes. Em relação a inexistência de aspectos negativos nos cereais matinais, $42,0 \%$ foi a proporção complementar de respostas obtidas. 
Tabela 4.2.5 Quantidade de respondentes que declararam aspectos positivos e negativos no cereal matinal (valores em porcentagem)

\begin{tabular}{c|c|c|c|c|c|c|c|c|c|c}
\hline \multirow{2}{*}{ CITAÇÕES } & \multicolumn{2}{|c|}{ RESPOND. } & \multicolumn{4}{|c|}{ FAIXA ETÁRIA } & \multicolumn{3}{c}{ RENDA IND.ANUAL - US\$ } \\
\cline { 2 - 11 } & EUA & BRASIL & \multicolumn{1}{|c|}{$18-35$ anos } & \multicolumn{2}{c|}{$36-50$ anos } & \multicolumn{2}{c}{$<25$ mil } & \multicolumn{2}{c}{$\geq 25$ mil } \\
\cline { 3 - 11 } & & & EUA & BR & EUA & BR & EUA & BR & EUA & BR \\
\hline Aspectos positivos & 100,0 & 100,0 & 100,0 & 100,0 & 100,0 & 100,0 & 100,0 & 100,0 & 100,0 & 100,0 \\
\hline Base & 50 & 50 & 23 & 26 & 27 & 24 & 24 & 26 & 26 & 24 \\
\hline \multirow{2}{*}{ Aspectos negativos } & 58,0 & 58,0 & 62,5 & 55,5 & 54,0 & 61,0 & 58,0 & 50,0 & 58,4 & 67,0 \\
\hline Nenhum aspecto negativo & 42,0 & 42,0 & 37,5 & 44,5 & 46,0 & 39,0 & 42,0 & 50,0 & 41,6 & 33,0 \\
\hline Base & 50 & 50 & 24 & 27 & 26 & 23 & 26 & 26 & 24 & 24 \\
\hline
\end{tabular}

\section{aspectos positivos}

Em geral, os aspectos positivos relacionados pelos entrevistados foram:

- valor nutricional - decorrente da presença de vitaminas, minerais e proteínas;

- aspecto funcional - produto rico em fibra, que contribue para a regularização do funcionamento do aparelho digestivo. No Brasil, foi acrescentado que o aspecto funcional do cereal propicia a limpeza do organismo e, consequentemente, torna a pele mais viçosa;

- beneficios - é considerado um alimento leve ("não pesa no estômago"), que alimenta e sustenta (poder de saciedade) o indivíduo por um longo espaço de tempo de forma divertida e prazeirosa. Apresenta praticidade e rapidez na sua aplicação e pode substituir uma refeição convencional, como por exemplo, café da manhã, almoço, lanche e jantar;

- op̧̧ões - o respondente norte-americano destacou a gama diversificada de opç̃̃es ofertada pelo mercado. Esse consumidor pode fazer sua escolha dentre uma infinidade de marcas por tipo de produto, como exemplo, cereais com maior ou menor teor de açúcar, de fibras, entre outros. Por outro lado, no Brasil, o mercado consumidor de cereais vem, recentemente, ofertando alguns tipos de cereais matinais importados, bem como tem introduzido algumas novidades desenvolvidas pelos produtores brasileiros. Com o tempo, esses fatores estarão propiciando uma oferta mais diversificada dessa categoria de gênero alimentício.

\section{aspectos negativos}

Segundo os entrevistados, os cereais também apresentam alguns aspectos negativos. No Brasil, foram ressaltados os seguintes pontos:

- excesso de açúcar existente na composição do produto pode levar o indivíduo a engordar;

- elevado preço do cereal em comparação com a barata matéria-prima empregada restringe o consumo do produto;

- a baixa relação entre custo e benefício, isto é, seu preço é alto e o rendimento reduzido. 
Entre os respondentes brasileiros, verifica-se uma maior concentração das respostas na faixa etária entre 36 a 50 anos $(61,0 \%)$. Em relação à renda individual anual, as respostas concentraram-se na faixa de maior poder aquisitivo $(67,0 \%)$.

Quanto ao entendimento dos respondentes norte-americanos, foram enfatizados os seguintes aspcetos negativos nos cereais matinais:

- a incorporação de certos elementos como corantes e/ou aromatizantes dão a conotação de um produto "artificial" (por exemplo, o cereal "Froot Loops");

- o elevado teor de açúcar presente em alguns tipos de cereais, por exemplo, "Frosted Flakes", foi considerado prejudicial à saúde do indivíduo, em especial, para o público infantil.

- o consumo frequente do cereal matinal (monotonia no consumo) reduz o aspecto "apetitoso" do produto;

- o cereal por ser um produto de prático preparo e consumo tem levado o consumidor norteamericano a se comportar de forma mais "individualista". Os entrevistados ressaltaram que, no horário das refeições, vem sendo rara a união de seus integrantes.

Observando os dados apresentados na Tabela 4.2.5, constata-se uma maior concentração das respostas na faixa etária de até 35 anos $(62,5 \%)$. Em relação à renda individual anual, as respostas concentraram-se na faixa de maior poder aquisitivo $(58,4 \%)$.

\subsubsection{Perfil dos compradores e consumidores de cereais matinais}

Para concluir esta primeira parte sobre o entendimento, mais amplo, dos consumidores brasileiros e norte-americanos acerca do produto - cereal matinal, são apresentados os resultados obtidos quanto às características sócio-econômicas dos compradores e consumidores do referido produto, segundo a opinião dos entrevistados.

Conforme a Tabela 4.2.6, as declarações dadas pelos entrevistados foram interpretadas como perfil dos compradores e consumidores de cereais matinais. Como a questão era aberta, os entrevistados podiam citar mais de um aspecto relacionado com as características sócio-econômicas dos usuários do referido produto. Dessa forma, todos os entrevistados, nos EUA, e $98,0 \%$, no Brasil, citaram aspectos referentes às condições sócio-econômicas dos consumidores de cereais matinais. Além disso, todos os entrevistados norte-americanos e $90,0 \%$ dos brasileiros informaram, também, elementos relacionados ao grau de instrução de quem compra e consume esse tipo de produto. Em relação ao aspecto "estilo de vida", todos os norte-americanos citaram esse item, enquanto no Brasil, a proporção foi de $90,0 \%$. Quanto ao aspecto "dieta alimentar", $70,0 \%$ dos brasileiros fizeram menção ao item. Por outro lado, nos EUA, a proporção foi de $38,0 \%$. Acerca dos aspectos "público infantil" e "público adulto", 67,0\%, em média, dos brasileiros salientaram esse aspecto. Nos EUA, a proporção foi de $36,0 \%$ para cada um dos itens identificados. 


\section{condições econômicas e grau de instrução}

Para a totalidade dos entrevistados norte-americanos, é neutro o efeito das "condições econômicas" e do "grau de instrução" sobre o comportamento do usuário de cereal matinal. O fato do norte-americano consumir ou não esse produto não depende de ele possuir maior ou menor poder aquisitivo, nem tão pouco, uma instrução esmerada ou básica. O consumo do cereal matinal está instrinsicamente ligado ao aspecto cultural desse país. Desde a infância, o cidadão norteamericano emprega o cereal matinal como um item básico na sua dieta alimentar diária.

Por outro lado, segundo o entendimento dos brasileiros entrevistados, o cereal matinal é considerado um item "supérfluo" na dieta alimentar. Além disso, foi ressaltado o aspecto negativo da sua relação custo e beneficio, quando comparado com o café da manhã (café, leite, pão, manteiga ou margarina), habitualmente, consumido pela população brasileira. Dessa forma, o cereal foi considerado um produto caro e que apresenta baixo rendimento. No Brasil, o consumo de cereal matinal é mais comum nas classes sociais mais abastadas economicamente falando, bem como por pessoas com maior grau de instrução. Ainda, de acordo com os respondentes, foi destacado que esses consumidores fazem uma análise "racional" no momento de adquirir o produto. Analisam, além do elemento "preço", fatores benéficos, como por exemplo, o valor nutricional dos cereais matinais e o papel funcional que o produto desempenha no nosso organismo (regularização do funcionamento do aparelho digestivo).

Como mostra a Tabela 4.2.6, para os dois aspectos anteriormente analisados, 96,0\%, em média, das respostas ficaram concentradas na faixa etária entre 36 a 50 anos. Quanto à renda individual anual, em torno de $94,0 \%$ das respostas concentraram-se na faixa de maior poder aquisitivo.

\section{estilo de vida}

Para todos entrevistados norte-americanos, o aspecto "estilo de vida" está vinculado aos hábitos culturais inerentes a cada país e, nos dias de hoje, está associado, também, ao fator "tempo". $O$ cereal matinal é incorporado à dieta alimentar diária do norte-americano e, ainda, muito valorizado por esse consumidor. Além de alimentar e sustentar o indivíduo por longo espaço de tempo, é considerado saudável ao organismo e, sobretudo, por não exigir o emprego demasiado de tempo no seu preparo e consumo.

Quanto aos entrevistados brasileiros, observou-se que o consumo de cereal matinal está associado à adoção de uma determinada "filosofia de vida". Segundo os entrevistados, são pessoas denominadas de "geração saúde", isto é, que valorizam o "culto ao corpo" e, consequentemente, praticam atividades esportivas para manter a forma fisica. Buscam ingerir uma alimentação diferenciada, composta por produtos naturais, ricos em fibra e com teores reduzidos de gordura e colesterol. O fator "praticidade" no preparo e consumo do produto também foi ressaltado por esse grupo de entrevistados. Verifica-se uma maior concetração das respostas na faixa etária de até 35 anos $(92,3 \%)$. Em relação à renda individual anual, todas as respostas concentraram-se na faixa de menor poder aquisitivo. 
Tabela 4.2.6 Quantidade de respondentes que declararam aspectos do perfil dos compradores e consumidores de cereais matinais (valores em porcentagem)

\begin{tabular}{|c|c|c|c|c|c|c|c|c|c|c|}
\hline \multirow{3}{*}{ CITAÇÕES } & \multicolumn{2}{|c|}{ RESPOND. } & \multicolumn{4}{|c|}{ FAIXA ETÁRIA } & \multicolumn{4}{|c|}{ RENDA IND.ANUAL - US\$ } \\
\hline & \multirow[t]{2}{*}{ EUA } & \multirow[t]{2}{*}{ BRASIL } & \multicolumn{2}{|c|}{$18-35$ anos } & \multicolumn{2}{|c|}{$36-50$ anos } & \multicolumn{2}{|c|}{$<25 \mathrm{mil}$} & \multicolumn{2}{|c|}{$\geq 25 \mathrm{mil}$} \\
\hline & & & EUA & $\mathrm{BR}$ & EUA & BR & EUA & $\mathrm{BR}$ & EUA & BR \\
\hline Condições econômicas & 100,0 & 98,0 & 100,0 & 96,0 & 100,0 & 100,0 & 100,0 & 100,0 & 100,0 & 95,8 \\
\hline Sem mençðes & 0 & 2,0 & 0 & 4,0 & 0 & 0 & 0 & 0 & 0 & 4,2 \\
\hline Base & 50 & 50 & 23 & 26 & 27 & 24 & 24 & 26 & 26 & 24 \\
\hline Grau de instrução & 100,0 & 90,0 & 100,0 & 87,0 & 100,0 & 92,5 & 100,0 & 87,5 & 100,0 & 92,3 \\
\hline Sem mençães & 0 & 10,0 & 0 & 13,0 & 0 & 7,5 & 0 & 12,5 & 0 & 7,7 \\
\hline Base & 50 & 50 & 23 & 23 & 27 & 27 & 24 & 24 & 26 & 26 \\
\hline Estilo de vida & 100,0 & 90,0 & 100,0 & 92,3 & 100,0 & 87,5 & 100,0 & 100,0 & 100,0 & 81,5 \\
\hline Sem menções & 0 & 10,0 & 0 & 7,7 & 0 & 12,5 & 0 & 0 & 0 & 18,5 \\
\hline Base & 50 & 50 & 23 & 26 & 27 & 24 & 24 & 23 & 26 & 27 \\
\hline Dieta alimentar & 38,0 & 70,0 & 41,6 & 52,0 & 34,6 & 88,0 & 30,0 & 70,0 & 54,2 & 74,0 \\
\hline Sem menções & 62,0 & 30,0 & 58,4 & 48,0 & 65,4 & 12,0 & 70,0 & 30,0 & 45,8 & 26,0 \\
\hline Base & 50 & 50 & 24 & 25 & 26 & 25 & 26 & 27 & 24 & 23 \\
\hline Público infantil & 36,0 & 68,0 & 46,0 & 72,0 & 27,0 & 64,0 & 44,0 & 66,7 & 28,0 & 69,5 \\
\hline Sem mencões & 64,0 & 32,0 & 54,0 & 28,0 & 73,0 & 36,0 & 56,0 & 33,3 & 72,0 & 30,5 \\
\hline Base & 50 & 50 & 24 & 25 & 26 & 25 & 25 & 27 & 25 & 23 \\
\hline Público adulto & 36,0 & 66,0 & 46,0 & 80,7 & 27,0 & 50,0 & 44,0 & 70,4 & 28,0 & 61,0 \\
\hline Sem menções & 64,0 & 34,0 & 54,0 & 19,3 & 73,0 & 50,0 & 56,0 & 29,6 & 72,0 & 39,0 \\
\hline Base & 50 & 50 & 24 & 26 & 26 & 24 & 25 & 27 & 25 & 23 \\
\hline
\end{tabular}

\section{dieta alimentar}

Acerca do aspecto "dieta alimentar", os respondentes brasileiros consideraram que as pessoas com propensão para engordar e preocupação com a forma fisica devem seguir uma recomendação médica, ou ainda, escolher aqueles que contenham reduzido teor de açúcar em sua composição, como por exemplo, o produto denominado "All Bran". Observa-se uma maior concentração das respostas na faixa etária entre 36 a 50 anos $(88,0 \%)$. Quanto à renda individual anual, as respostas concentraram-se na faixa de maior poder aquisitivo $(74,0 \%)$.

Segundo o entendimento dos entrevistados norte-americanos, o indivíduo que esteja seguindo uma dieta alimentar para perder peso não precisa evitar o consumo de cereal matinal. Ainda, de acordo com a opinião desses respondentes, o cereal, além de alimentar, confere poder de saciedade, isto é, sustenta o indivíduo por um longo espaço de tempo. Verifica-se uma maior concentração das respostas na faixa etária de até 35 anos $(41,6 \%)$. Quanto à renda individual anual, as respostas concentraram-se na faixa de maior poder aquisitivo $(54,2 \%)$. 


\section{público infantil}

Segundo os entrevistados norte-americanos, de um modo geral, não há limite de faixa etária para o consumo de cereais matinais. É mais uma questão de "paladar", isto é, produtos adocicados, normalmente, tornam-se mais apetitosos para as crianças do que para os adultos. Nesse sentido, foram citadas as marcas "Frosted Flakes", "Cherrios", "Smacks", entre outras. Observa-se uma maior concentração das respostas na faixa etária até 35 anos $(46,0 \%)$. Quanto à renda individual anual, as respostas concentraram-se na faixa de menor poder aquisitivo $(44,0 \%)$.

No Brasil, observou-se que os cereais matinais com elevado teor de açúcar em sua composição, por exemplo, o produto da marca "Sucrilhos", está, basicamente, voltado para o público jovem. Além da questão "paladar", foi ressaltado o aspecto "lúdico", isto é, no momento em que está consumindo o cereal, o consumidor procura aliar a "descontração" à busca por uma alimentação saudável. Verifica-se uma maior concentração das respostas na faixa etária de até 35 anos $(72,0 \%)$. Quanto à renda individual anual, as respostas concentraram-se na faixa de maior poder aquisitivo $(69,5 \%)$.

\section{público adulto}

Nos EUA, o fato de alguns tipos de cereais matinais possuírem uma concentração maior de açúcar em relação a outros, não impede que muitas pessoas, na fase adulta, continuem consumindo o cereal que era valorizado na sua infâncial juventude. Por exemplo, foram destacados os produtos denominados "Cherrios", "Frosted Flakes", "Smacks", entre outros. Verifica-se que o entendimento verbalizado está concentrado na faixa etária de até 35 anos $(46,0 \%)$. Em relação à renda individual anual, a concentração das respostas deu-se na faixa de menor poder aquisitivo $(70,4 \%)$.

Para os entrevistados brasileiros, os cereais pertencentes à categoria "fibras" ("Fibre 1", "All Bran") e "multingredientes" ("Granola" e "Muesli") são mais valorizados pela população adulta. Neste caso, existe uma reflexão racional do consumidor ao escolher o tipo de cereal a ser adquirido. Constatou-se que o adulto busca o preenchimento de necessidades ligadas ao aspecto funcional dos cereais, isto é, a ingestão de fibra levando à regularização do funcionamento do aparelho digestivo. Observa-se uma maior concentração das respostas na faixa etária de até 35 anos $(80,7 \%)$. Quanto à renda individual anual, as respostas concentraram-se na faixa de menor poder aquisitivo $(70,4 \%)$.

Concluindo, independentemente das características de cada mercado consumidor, verificou-se que os cereais compreendem determinadas características básicas e padrão na opinião dos entrevistados. É um produto considerado saudável (rico em vitaminas, minerais e fibra), prático para o preparo e o consumo, além de alimentar e de conferir saciedade por um longo espaço de tempo. 
As variações de opinião identificadas estão, basicamente, relacionadas com o aspecto cultural de cada país. Os entrevistados norte-americanos consideram o cereal matinal um produto "básico" em sua alimentação diária. Para os respondentes brasileiros o consumo do cereal matinal está relacionado à adoção de uma "filosofia de vida" de "culto ao corpo" e que valoriza o aspecto "funcional" do produto.

\section{Embalagens de Cereais Matinais}

\subsubsection{Informações impressas nas embalagens de cereais matinais lembradas pelos respondentes para as marcas mencionadas}

De acordo com a Tabela 4.2.7, foram computadas as marcas de cereais matinais que os entrevistados mencionaram consumir. A partir do conjunto informativo impresso nessas embalagens, as declarações dadas pelos entrevistados foram caracterizadas como "informações lembradas". Em termos das "marcas em geral", $58,0 \%$ dos entrevistados brasileiros citaram lembrar de algumas informações contidas no rótulo das embalagens de cereais. Nos EUA, a proporção foi de $62,0 \%$. Quanto às marcas "Muesli" e "Aveia", 23,0\% dos entrevistados brasileiros, em média, citaram-nas. Em relação aos dois grupos de marcas 1) "Corn Flakes", "Frosted Flakes", "Banana Nut Cunch", "Raisin Bran" e 2) "Rice Krispies", "Cherrios", "Sugar Pops", F"ruit Pebbles" os entrevistados norte-americanos citaram-nas na proporção de $34,0 \%$.

Tabela 4.2.7 Quantidade de respondentes que declararam ter se lembrado das informações impressas nas embalagens de cereais matinais que costuma consumir (valores em porcentagem)

\begin{tabular}{|c|c|c|c|c|c|c|c|c|c|c|}
\hline \multirow{3}{*}{ CITAÇÕES } & \multicolumn{2}{|c|}{ RESPOND. } & \multicolumn{4}{|c|}{ FAIXA ETÁRIA } & \multicolumn{4}{|c|}{ RENDA IND.ANUAL - US\$ } \\
\hline & \multirow[t]{2}{*}{ EUA } & \multirow[t]{2}{*}{ BRASIL } & \multicolumn{2}{|c|}{ 18-35 anos } & \multicolumn{2}{|c|}{$36-50$ anos } & \multicolumn{2}{|c|}{$<25 \mathrm{mil}$} & \multicolumn{2}{|c|}{$\geq 25 \mathrm{mil}$} \\
\hline & & & EUA & $\mathrm{BR}$ & EUA & $\mathrm{BR}$ & EUA & BR & EUA & BR \\
\hline Marcas em geral & 62,0 & 58,0 & 54,0 & 48,0 & 63,0 & 68,0 & 65,4 & 60,0 & 58,4 & 56,0 \\
\hline Sem menções & 38,0 & 42,0 & 46,0 & 52,0 & 37,0 & 32,0 & 34,6 & 40,0 & 41,6 & 44,0 \\
\hline Base & 50 & 50 & 23 & 25 & 27 & 25 & 26 & 25 & 24 & 25 \\
\hline Muesli & 0 & 24,0 & 0 & 23,0 & 0 & 25,0 & 0 & 7,7 & 0 & 41,7 \\
\hline Sem menções & 0 & 76,0 & 0 & 77,0 & 0 & 75,0 & 0 & 92,3 & 0 & 58,3 \\
\hline Aveia & 0 & 22,0 & 0 & 23,0 & 0 & 21,0 & 0 & 24,0 & 0 & 25,0 \\
\hline Sem menç̃es & 0 & 78,0 & 0 & 77,0 & 0 & 79,0 & $\mathbf{0}$ & 76,0 & 0 & 75,0 \\
\hline Base & 0 & 50 & 0 & 26 & 0 & 24 & 0 & 26 & 0 & 24 \\
\hline $\begin{array}{c}\text { Corn Flakes, Frosted Flakes, } \\
\text { 3anana Nut Crunch. Raisin Bran }\end{array}$ & 34,0 & 0 & 25,0 & 0 & 42,3 & 0 & 30,7 & 0 & 37,5 & 0 \\
\hline Sem menções & 66,0 & 0 & 75,0 & 0 & 57,7 & 0 & 69,3 & 0 & 62,5 & 0 \\
\hline $\begin{array}{l}\text { 2ice Krispies, Cherrios, Sugar } \\
\text { Pops, Fruit Pebbles }\end{array}$ & 34,0 & 0 & 45,8 & 0 & 30,0 & 0 & 34,6 & 0 & 33,3 & 0 \\
\hline Sem mençôes & 66,0 & 0 & 54,2 & 0 & 70,0 & 0 & 65,4 & 0 & 66,7 & 0 \\
\hline Base & 50 & 0 & 24 & 0 & 26 & 0 & 26 & 0 & 24 & 0 \\
\hline
\end{tabular}




\section{marcas em geral}

Neste item, os entrevistados brasileiros consideraram, de maneira geral, as marcas que costumam adquirir para relacionar quais informações, extraídas do conjunto informativo impresso nas embalagens, estariam presentes em sua memória. Dentre as informações declaradas pelos entrevistados, destacaram-se as seguintes:

- "chamadas"/ "splashes" acerca do teor de fibra, açúcar e/ou colesterol;

* composição do produto/ lista de ingredientes ajuda, por exemplo, na identificação do sabor "chocolate" de alguns tipos de cereais matinais;

- foto do cereal (tigela, próprio produto, leite, frutas, mel) permite que o consumidor tenha uma idéia (aparência) acerca do conteúdo inserido na embalagem, bem como leva o usuário a fazer associações às possiveis formas de consumo do produto;

- prazo de validade do cereal;

- especificação/ tipo do cereal, por exemplo, "à base de trigo integral", "aveia com flocos finos";

- nome do produto e marca são destacados em função da arte gráfica (tamanho da letra, colorido) e da logotipia (por exemplo, estilo da letra) empregadas;

- colorido das embalagens;

- composição nutricional (tabela nutricional);

- formal formato das embalagens, por exemplo, chama a atenção do consumidor para o fato de que é menor o tamanho dos cartuchos dos cereais das categorias muesli e granola em relação às demais categorias do referido produto;

- receitas

Conforme a Tabela 4.2.7, verifica-se uma maior concentração das respostas na faixa etária entre 36 a 50 anos $(68,0 \%)$. Quanto à renda individual anual, as respostas concentraram-se na faixa de menor poder aquisitivo $(60,0 \%)$.

De acordo com o entendimento dos entrevistados norte-americanos, as informações mais lembradas estão relacionadas a seguir:

- nome do produto e marca são destacados em função da arte gráfica (tamanho da letra, colorido) e da logotipia (por exemplo, estilo da letra) empregadas. Segundo os entrevistados, essas informações estão vinculadas às cores vibrantes, ou ainda, às fotos de personagens ("Tony the Tiger", por exemplo, no cereal "Frosted Flakes");

* informações nutricionais extraidas da tabela nutricional, por exemplo, teor reduzido de gordura/ "low fat", teor calórico, de vitaminas e/ou minerais;

* símbolos (por exemplo, de um coração) de instituições que endossam/ apoiam o consumo do produto, destacando seu lado benéfico à saúde do consumidor; 
- foto do cereal contendo, por exemplo, uma tigela, o próprio cereal, leite, uva-passa e nozes permite que o consumidor tenha uma idéia (aparência) acerca do conteúdo inserido na embalagem;

- composição do produto/ lista de ingredientes ajuda na identificação do tipo de cereal matinal ofertado nas gôndolas dos pontos-de-venda;

- informações promocionais como receitas, jogos, brinquedinhos, histórico sobre o produto, entre outras;

* "chamadas" atraindo o consumidor pela presença de cupons (desconto na compra de uma outra embalagem), ou ainda, destaque em relação à quantidade inserida no cartucho (peso líquido);

- prazo de validade;

* formal formato das embalagens e logotipia são padronizadas, entretatno, às vezes, sofrem alterações em função de alguma data comemorativa;

- receitas, sugestões quanto à forma de preparo.

Nos EUA, observa-se uma maior concetração das respostas na faixa etária entre 36 a 50 anos $(63,0 \%)$. Quanto à renda individual anual, as respostas concentraram-se na faixa de menor poder aquisitivo $(65,4 \%)$.

\section{"Muesli"}

No Brasil, para esta categoria de cereais matinais, os entrevistados destacaram como "informações lembradas" aquelas que se encontram relacionadas abaixo:

- composição do produto/ lista de ingredientes ajuda na identificação do tipo de cereal matinal ofertado nas gôndolas dos pontos-de-venda;

- o visual proveniente da foto do cereal aguça a vontade do consumidor querer comprar e, consequentemente, experimentar o produto. Foram ressaltados os seguintes elementos: grãos dos cereais inseridos na embalagem; frutas, por exemplo, maçã e amêndoas; canela, leite e mel;

* preço do produto e conteúdo (peso) líquido levam o consumidor a fazer uma avaliação quanto à relação custo/ beneficio com a aquisição do cereal;

- composição nutricional e o valor calórico do cereal em $100 \mathrm{~g}$ do produto (tabela nutricional);

- "chamadas"/ "splashes" acerca do teor de açúcar;

Conforme a Tabela 4.2.7, verifica-se uma maior concentração das respostas na faixa etária entre 36 a 50 anos $(25,0 \%)$. Quanto à renda individual anual, as respostas concentraram-se na faixa de maior poder aquisitivo $(41,7 \%)$. 


\section{"Aveia"}

De acordo com o entendimento dos entrevistados brasileiros, a "Aveia" é um produto, tradicionalmente, introduzido a partir da infância na dieta alimentar do consumidor. As "informações lembradas" estão relacionadas a seguir:

- colorido da embalagem, nome do cereal e logomarca (foto do "padre") transmitem a idéia de "tradição". O produto é introduzido na dieta alimentar do brasileiro desde a sua infância;

- receitas de bolos e "cookies" e bolachinhas;

* composição do produto/ lista de ingredientes;

* prazo de validade;

* especificação/ tipo do cereal, por exemplo, "aveia com flocos finos".

Observa-se uma maior concentração das respostas na faixa etária de até 35 anos (23,0\%). Quanto à renda individual anual, as respostas concentraram-se na faixa de maior poder aquisitivo $(25,0 \%)$.

\section{"Corn Flakes", "Frosted Flakes”, "Banana Nut Crunch", "Raisin Bran”}

Nos EUA, para esse grupo de cereais matinais, os entrevistados destacaram como as informações mais lembradas aquelas que se encontram relacionadas abaixo:

* foto do cereal contendo, por exemplo, flocos de milho, uma tigela e leite são elementos que atraem a atenção do consumidor e além disso, dão uma idéia (aparência) acerca do conteúdo inserido na embalagem;

* emprego de cores vibrantes (azul escuro, amarelo, magenta) e personagens ("Frosted Flakes" "Tony the Tiger", "Corn Flakes" - galo) são elementos que ajudam na identificação do cereal;

* informação nutricional (teor calórico, de gordura, vitamínico e de minerais);

- símbolos de instituições (por exemplo, coração da "American Heart Association") que endossam/ apoiam o consumo do produto, destacando seu lado benéfico à saúde do consumidor;

- receitas, por exemplo, de típicos bolinhos norte-americano denominados "muffins" e "banana nut bread";

- cupons que atraem o consumidor em função do desconto aplicado na compra de uma outra embalagem do produto.

Observa-se uma maior concentração das respostas na faixa etária de até 35 anos $(45,8 \%)$. Quanto à renda individual anual, as respostas concentraram-se na faixa de menor poder aquisitivo $(34,6 \%)$.

\section{"Rice Krispies”, “Cherrios”, “Sugar Pops”, "Fruit Pebbles"}

Segundo o entendimento dos entrevistados norte-americanos, para esse grupo de cereais matinais, as "informações lembradas" encontram-se relacionadas a seguir: 
- nome do produto é destacado em função da arte gráfica (tamanho da letra, colorido);

- personagens ("Rice Krispies" - gnomos, duendes; "Cherrios" - abelhinhas; "Fruit Pebbles" - os "flintstones") e o uso de cores vibrantes, por exemplo, no produto "Sugar Pops" predomina a cor amarelo vibrante são elementos que ajudam na identificação do cereal;

- informação nutricional sobre o valor vitamínico do produto;

- recomendações quanto à porção a ser consumida;

- receitas (docinhos que levam o nome do próprio produto "Rice Krispies" e sugestões alternativas de utilização do cereal;

- cupons que atraem o consumidor em função do desconto aplicado na compra de uma outra embalagem do produto.

Observa-se uma maior concentração das respostas na faixa etária entre 36 a 50 anos $(42,3 \%)$. Quanto à renda individual anual, as respostas concentraram-se na faixa de maior poder aquisitivo $(37,5 \%)$.

\subsubsection{Entendimento dos respondentes acerca do conceito "papel da embalagem de cereal matinal"}

Conforme a Tabela 4.2.8, declarações dadas pelos entrevistados foram interpretadas como o papel das embalagens de cereais matinais. Dessa forma, 96,0\% dos entrevistados, no Brasil, e 94,0\%, nos EUA, citaram aspectos referentes à "proteção e conservação" do produto através da embalagem. Além disso, 70,0\% dos brasileiros informaram, também, elementos relacionados à "prestação de serviço" desempenhada pelo invólucro protetor dos cereais matinais. Nos EUA, a proporção foi de, apenas, 20,0\%. Quanto ao aspecto "fonte de informação", no Brasil, 70,0\% dos entrevistados fizeram menção ao item. Por outro lado, nos EUA, a proporção foi de $54,0 \%$.

\section{proteção e conservação}

Os entrevistados informaram que cabe à embalagem de cereais matinais acondicionar o produto, vedar/ lacrar o cereal, protegendo-o de ações mecânicas, ou ainda, de contaminações provenientes do meio externo, bem como preservar o produto, mantendo suas características próprias, por exemplo, estar sempre crocante.

No Brasil, verifica-se uma maior concentração das respostas na faixa etária entre 36 a 50 anos $(100,0 \%)$. Quanto à renda individual anual, a proporção foi a mesma $(96,0 \%)$ nas faixas de menor e de maior poder aquisitivo. Nos EUA, em relação à faixa etária, observa-se uma inversão na concentração das respostas, ou seja, destacou-se a faixa de até 35 anos $(96,0 \%)$. Acerca da renda individual anual, as respostas concentraram-se na faixa de menor poder aquisitivo $(96,0 \%)$. 
Tabela 4.2.8 Entendimento do conceito "papel da embalagem de cereal matinal" (valores em porcentagem)

\begin{tabular}{|c|c|c|c|c|c|c|c|c|c|c|}
\hline \multirow{3}{*}{ CITAÇÕES } & \multicolumn{2}{|c|}{ RESPOND. } & \multicolumn{4}{|c|}{ FAIXA ETÁRIA } & \multicolumn{4}{|c|}{ RENDA IND.ANUAL - US\$ } \\
\hline & \multirow[t]{2}{*}{ EUA } & \multirow[t]{2}{*}{ BRASIL } & \multicolumn{2}{|c|}{$18-35$ anos } & \multicolumn{2}{|c|}{$36-50$ anos } & \multicolumn{2}{|c|}{$<25 \mathrm{mil}$} & \multicolumn{2}{|c|}{$\geq 25 \mathrm{mil}$} \\
\hline & & & EUA & BR & EUA & $\mathrm{BR}$ & EUA & $\mathrm{BR}$ & EUA & BR \\
\hline Proteção e conservação & 94,0 & 96,0 & 96,0 & 92,0 & 92,0 & $\overline{100,0}$ & 96,0 & $\overline{96,0}$ & 92,0 & 96,0 \\
\hline Sem citações & 6,0 & 4,0 & 4,0 & 8,0 & 8,0 & 0 & 4,0 & 4,0 & 8,0 & 4,0 \\
\hline Prestação & 20,0 & 70,0 & 17,0 & 81,0 & 23,0 & 58,0 & 19,0 & 77,0 & 21,0 & 62,5 \\
\hline Sem citações & 80,0 & 30,0 & 83,0 & 19,0 & 77,0 & 42,0 & 81,0 & 23,0 & 79,0 & 37,5 \\
\hline Base & 50 & 50 & 24 & 26 & 26 & 24 & 26 & 26 & 24 & 24 \\
\hline Fonte de informação & 54,0 & 88,0 & 56,5 & 88,0 & 52,0 & 87,5 & 46,0 & 88,0 & 62,5 & 87,5 \\
\hline Sem citações & 46,0 & 12,0 & $43 \div 5$ & 12,0 & 48,0 & 12,5 & 54,0 & 12,0 & 37,5 & 12,5 \\
\hline Base & 50 & 50 & 23 & 26 & 27 & 24 & 26 & 26 & 24 & 24 \\
\hline
\end{tabular}

\section{prestação de serviço}

No Brasil, quanto ao item "prestação de serviço", os entrevistados destacaram os seguintes aspectos pertinentes ao papel desempenhado pelas embalagens de cereais matinais:

- o consumidor se sente atraído pela arte gráfica formada pelo conjunto de embalagens nas gôndolas dos pontos-de-venda;

- apresentação e venda do produto;

- identificação da marcal fabricante por intermédio do emprego de um conjunto de cores típico de cada agente produtor;

- praticidade no manuseio.

Conforme a Tabela 4.2.8, observa-se uma maior concentração das respostas na faixa etária de até 35 anos $(81,0 \%)$. Quanto à renda individual anual, as respostas concentraram-se na faixa de menor poder aquisitivo $(77,0 \%)$.

Segundo os entrevistados norte-americanos, o aspecto "prestação de serviço" está relacionado com a comunicação estabelecida entre o consumidor e a empresa, via dados sobre o Serviço de Atendimento ao Consumidor impressos na embalagem do cereal matinal. Nesse sentido, os entrevistados ressaltaram que o atendimento decorrente de uma reclamação gerada pelo consumidor representa uma "prestação de serviço". Verifica-se que as respostas concentraram-se na faixa etária entre 36 a 50 anos $(23,0 \%)$. Em relação à renda individual anual, a concentração das respostas ocorreu na faixa de maior poder aquisitivo $(21,0 \%)$.

\section{fonte de informação}

Os entrevistados reconheceram o papel informativo e esclarecedor desempenhado pelas embalagens de cereais matinais. Foi ressaltado que as informações impressas nas embalagens do 
referido produto transmitem ao consumidor noção do seu conteúdo (composição química e nutricional), bem como sugerem usos alternativos de consumo.

De acordo com a Tabela 4.2.8, no Brasil, verifica-se uma maior concentração das respostas na faixa etária de até 35 anos $(88,0 \%)$. Quanto à renda individual anual, as respostas concentraram-se na faixa de menor poder aquisitivo $(\mathbf{8 8 , 0 \% )}$. Nos EUA, a maior concentração das respostas ocorreu na faixa etária de até 35 anos $(56,5 \%)$. Em relação à renda individual anual, as respostas concentraram-se na faixa de maior poder aquisitivo $(62,5 \%)$.

\subsubsection{Facilidade/ dificuldade em encontrar as informações impressas nas embalagens de cereais matinais}

Conforme a Tabela 4.2.9, declarações dadas pelos entrevistados foram interpretadas como facilidade/ dificuldade em encontrar as informações impressas nas embalagens de cereais matinais. Dessa forma, todos os entrevistados, nos EUA, informaram ter facilidade em encontrar "todas as informações" existentes no rótulo das embalagens do referido produto. No Brasil, $98,0 \%$ dos entrevistados citaram que "determinadas informações" são encontradas com facilidade nas embalagens desse gênero alimentício. Além disso, 76,0\% dos entrevistados norte-americanos e $56,0 \%$ dos brasileiros mencionaram elementos relacionados à dificuldade em localizar "determinadas informações" impressas nas embalagens de cereais.

Tabela 4.2.9 Quantidade de respondentes que declararam aspectos relativos à facilidade/ dificuldade em encontrar as informações impressas nas embalagens de cereais matinais (valores em porcentagem)

\begin{tabular}{|c|c|c|c|c|c|c|c|c|c|c|}
\hline \multirow{3}{*}{ CITAÇÕES } & \multicolumn{2}{|c|}{ RESPOND. } & \multicolumn{4}{|c|}{ FAIXA ETÁRIA } & \multicolumn{4}{|c|}{ RENDA IND.ANUAL - US\$ } \\
\hline & \multirow[t]{2}{*}{ EUA } & \multirow[t]{2}{*}{ BRASIL } & \multicolumn{2}{|c|}{$18-35$ anos } & \multicolumn{2}{|c|}{$36-50$ anos } & \multicolumn{2}{|c|}{$<25 \mathrm{mil}$} & \multicolumn{2}{|c|}{$\geq 25 \mathrm{mil}$} \\
\hline & & & EUA & BR & EUA & BR & EUA & $\mathrm{BR}$ & EUA & BR \\
\hline $\begin{array}{l}\text { Facilidade: } \\
\text { Determinadas informações }\end{array}$ & 0 & 68,0 & 0 & 60,0 & 0 & 76,0 & 0 & 60,0 & 0 & 76,0 \\
\hline Todas as informações & 100,0 & 32,0 & 100,0 & 40,0 & 100,0 & 24,0 & 100,0 & 40,0 & 100,0 & 24,0 \\
\hline Base & 50 & 50 & 25 & 25 & 25 & 25 & 26 & 25 & 24 & 25 \\
\hline $\begin{array}{l}\text { Dificuldade: } \\
\text { Determinadas informações }\end{array}$ & 76,0 & 56,0 & 75,0 & 55,5 & 75,0 & 56,5 & 77,0 & 44,5 & 67,0 & 69,5 \\
\hline Nenhuma informação & 24,0 & 44,0 & 25,0 & 44,5 & 25,0 & 43,5 & 23,0 & 55,5 & 33,0 & 30,5 \\
\hline Base & 50 & 50 & 24 & 27 & 26 & 23 & 26 & 27 & 24 & 23 \\
\hline
\end{tabular}

\section{facilidade em encontrar determinadas informações}

No Brasil, dentre as informações citadas pelos entrevistados, destacam-se as seguintes:

* composição do produto/ lista de ingredientes;

" tabela nutricional e "chamadas"/ "splashes", por exemplo, "sem açúcar, menos sódio", "fortificado com 10 vitaminas e minerais", "rico em fibras"; 
- foto do produto (por exemplo: tigela, cereal, leite, mel);

- nome do cereal, marca (logotipo), nome do fabricante;

- prazo de validade, dados do SAC.

Conforme a Tabela 4.2.9, verifica-se uma maior concentração das respostas na faixa etária entre 36 a 50 anos $(76,0 \%)$. Quanto à renda individual anual, as respostas concentraram-se na faixa de maior poder aquisitivo $(76,0 \%)$.

\section{todas as informações}

Todos os entrevistados norte-americanos enfatizaram que o conjunto informativo impresso no rótulo das embalagens de cereais matinais é facilmente encontrado/ localizado nas diversas faces do cartucho protetor do referido produto. As informações mais destacadas por esse grupo de entrevistados encontram-se relacionadas a seguir:

- nome do cereal, marca (logotipo), endosso (símbolo de um coração) de instituições "American Heart Association" ligadas à área de saúde;

- "chamadas"/ "splashes", por exemplo, "baixo teor de gordura"/ "low fat", "enriquecido com vitaminas"/ "high level in vitamins", "rico em fibra"/ "extra fiber";

- recomendação de porções para o consumo;

- informação nutricional (tabela nutricional);

- identificação do produto através da cor base do cartucho, por exemplo, azul escuro - "Frosted Flakes", azul claro - "Rice Krispies", magenta - "Raisin Bran";

- foto do conteúdo (por exemplo: tigela, cereal, leite, mel).

\section{dificuldade em encontrar determinadas informações}

No Brasil, a dificuldade em encontrar determinadas informações nas embalagens de cereais matinais está relacionada com a inadequação da qualidade gráfica utilizada, bem como a falta de padronização em inserir uma dada informação pelos fabricantes de cereais matinais. Dentre os aspectos identificados pelos entrevistados, destacam-se os seguintes:

- letra em tamanho pequeno - dados do Serviço de Atendimento ao Consumidor/ SAC, tabela nutricional, composição do produto/ lista de ingredientes;

- impressão em relevo do item "prazo de validade" (informação apagada) e falta de padronização quanto ao local em que essa informação é impressa na embalagem.

Conforme a Tabela 4.2.9, verifica-se uma maior concentração das respostas na faixa etária entre 36 a 50 anos $(56,5 \%)$. Quanto à renda individual anual, as respostas concentraram-se na faixa de maior poder aquisitivo $(69,5 \%)$. 
O entendimento dos entrevistados norte-americanos foi muito semelhante ao dos brasileiros, ou seja, o consunidor poderá encontrar dificuldade em encontrar uma informação caso a qualidade gráfica da mesma não corresponda, ou ainda, pela falta de padronização na impressão do conjunto informativo nas embalagens de cereais matinais. Os entrevistados ressaltaram os seguintes aspectos:

- preço - deveria vir impresso na embalagem. Consumidores ressaltaram dificuldade em localizálo quando inserido nas gôndolas do ponto-de-venda;

* letra em tamanho pequeno - composição do produto/ lista de ingredientes, tabela nutricional, Serviço de Atendimento ao Consumidor - SAC;

" "chamadas"/ "splashes", por exemplo, cereal à base de trigo - conjunto de cores empregado não destaca a informação dentre as demais;

* impressão em relevo do item "prazo de validade" (informação apagada) e falta de padronização quanto ao local em que essa informação é impressa na embalagem;

- receitas - falta de padronização quanto ao local em que essa informação é impressa na embalagem, ora no dorso do cartucho, ora na face lateral da embalagem.

De acordo com a Tabela 4.2.9, verifica-se que a concentração das respostas nas faixas etárias de até 35 anos $(75,0 \%)$ e entre 36 a 50 anos $(75,0 \%)$ foi a mesma. Em relação à renda individual anual, as respostas concentraram-se na faixa de menor poder aquisitivo $(77,0 \%)$.

\subsubsection{Adequação/ inadequação da informação nutricional impressa nas embalagens de cereais matinais}

Conforme a Tabela 4.2.10, declarações dadas pelos entrevistados foram interpretadas como adequação/ inadequação da informação nutricional impressa nas embalagens de cereais matinais. $65 \%$ dos entrevistados, em média, consideraram adequada a forma como a informação nutricional vem sendo apresentada ao consumidor de cereais matinais.

Tabela 4.2.10 Quantidade de respondentes que declararam aspectos adequados/ inadequados da informação nutricional impressa nas embalagens de cereais matinais (valores em porcentagem)

\begin{tabular}{c|c|c|c|c|c|c|c|c|c|c}
\hline \multirow{2}{*}{ CITAÇÕES } & \multicolumn{2}{|c|}{ RESPOND. } & \multicolumn{4}{c|}{ FAIXA ETÁRIA } & \multicolumn{3}{c}{ RENDA IND.ANUAL - US\$ } \\
\cline { 2 - 11 } & EUA & BRASIL & \multicolumn{18}{c}{$18-35$ anos } & $36-50$ anos & \multicolumn{2}{c}{$<25$ mil } & \multicolumn{2}{c}{$\geq 25$ mil } \\
\cline { 3 - 11 } & & & EUA & BR & EUA & BR & EUA & BR & EUA & BR \\
\hline Aspectos adequados & 70,0 & 60,0 & 66,7 & 42,3 & 79,1 & 79,1 & 69,2 & 38,4 & 70,8 & 83,3 \\
\hline Aspectos inadequados & 30,0 & 40,0 & 33,3 & 57,7 & 20,9 & 20,9 & 30,8 & 61,6 & 29,2 & 16,7 \\
\hline Base & 50 & 50 & 24 & 26 & 26 & 24 & 26 & 26 & 24 & 24 \\
\hline
\end{tabular}




\section{aspectos adequados}

No Brasil e nos EUA, observou-se uma estreita coerência em relação ao entendimento dos entrevistados sobre a adequação da informação nutricional impressa nas embalagens de cereais matinais. Os aspectos considerados adequados pelos entrevistados destacam-se a seguir:

- o conjunto informativo transmite ao consumidor uma noção global sobre o valor nutricional do cereal matinal. Por exemplo, teor calórico proveniente de gorduras e/ou açúcar e concentração de nutrientes oriundos das vitaminas, minerais e/ou proteinas;

- o emprego de unidades de medida, como quilogramas/gramas, bem como de medidas caseiras permite que o consumidor controle, de maneira geral, o consumo de calorias diárias em sua dieta alimentar.

\section{aspectos inadequados}

Quanto aos aspectos inadequados, cabe ressaltar que os entrevistados brasileiros mostraram-se mais críticos em relação aos norte-americanos. No Brasil, os principais pontos considerados, destacam-se a seguir:

- informação técnica, ou seja, é exigido do consumidor, muitas vezes, que ele tenha conhecimento especifico de nutrição para balancear sua dieta e, consequentemente, preencher as necessidades nutricionais, em termos de vitaminas e minerais, recomendadas no próprio rótulo da embalagem do produto;

* na tabela nutricional, o consumidor gostaria que fossem adicionados exemplos "equivalência nutricional", isto é, menção de fontes alimentares substitutivas para cada nutriente especificado na tabela nutricional. Ainda, segundo os entrevistados, essa formatação da informação nutricional evitaria que o consumidor calculasse $o$ preenchimento de suas necessidades nutricionais;

- a falta de esclarecimento quanto ao emprego de termos técnicos, como por exemplo, kilocalorias versus calorias, dificulta a interpretação correta das informações contidas na tabela nutricional.

Nos EUA, os entrevistados, também, ressaltaram como aspecto inadequado a necessidade da adição de exemplos de "equivalência nutricional" dos cereais. Além disso, foi destacado que as informações contidas na tabela nutricional priorizam o consumo do produto quando adicionado ao leite. Os entrevistados salientaram que os cereais matinais têm sido, frequentemente, ingeridos a qualquer hora do dia. Assim, a composição da tabela nutricional poderia apresentar outras opções de combinações alimentares com a presença do cereal matinal. Esse tipo de informação destacaria, não só, a importância nutricional do produto na dieta alimentar do consumidor, bem como sua diversificada aplicação.

Referindo-se à faixa etária, identifica-se que os norte-americanos entre 36 a 50 anos tenderam a citar mais aspectos adequados do que aqueles da faixa entre 18 a 35 anos, ressaltando-se que a proporção dos aspectos adequados foi muito superior à proporção dos aspectos inadequados. Entre os brasileiros as porcentagens foram relativamente diferentes. Aqueles incluídos na faixa 
etária de 18 a 35 anos tenderam a citar mais aspectos inadequados do que aqueles situados na faixa etária de 36 a 35 anos.

\subsubsection{Entendimento dos respondentes acerca do conceito "embalagem ideal"}

De acordo com a Tabela 4.2.11, o conjunto informativo existente nas embalagens dos cereais matinais tem correspondido parcialmente ao preenchimento das necessidades do público consumidor desse gênero alimentício. Observa-se que, em torno de $80 \%$ do total de entrevistados entendem não ser necessária a adição de outras informações às já existentes nos rótulos da embalagens de cereais matinais. Apenas, cerca de $20 \%$ dos entrevistados entrevistados apontaram a necessidade de que fossem acrescentadas algumas informações àquelas já existentes na embalagem do referido produto. Além disso, em relação à questão de apresentar/ dispor as informações, $65 \%$ dos entrevistados, em média, manifestaram-se insatisfeitos com a forma como as informações vêm sendo apresentadas/ dispostas nas embalagens de cereais.

\section{não adicionar outras informạ̧̃es}

No Brasil, verifica-se uma maior concentração das respostas na faixa etária de até 35 anos $(96,1 \%)$. Quanto à renda individual anual, as respostas concentraram-se na faixa de menor poder aquisitivo $(89,3 \%)$. Em relação aos entrevistados norte-americanos, houve uma inversão na concentração das respostas. Observa-se, portanto, uma maior concentração delas na faixa etária entre 36 a 50 anos $(84,6 \%)$. No tocante à renda individual anual, a concentração das respostas ocorreu na faixa de maior poder aquisitivo $(87,5 \%)$.

Tabela 4.2.11 Entendimento do conceito "embalagem ideal" (valores em porcentagem)

\begin{tabular}{|c|c|c|c|c|c|c|c|c|c|c|}
\hline \multirow{3}{*}{ CITAÇÕES } & \multicolumn{2}{|c|}{ RESPOND. } & \multicolumn{4}{|c|}{ FAIXA ETÁRIA } & \multicolumn{4}{|c|}{ RENDA IND.ANUAL - US $\$$} \\
\hline & \multirow[t]{2}{*}{ EUA } & \multirow[t]{2}{*}{ BRASIL } & \multicolumn{2}{|c|}{$18-35$ anos } & \multicolumn{2}{|c|}{$36-50$ anos } & \multicolumn{2}{|c|}{$<25 \mathrm{mil}$} & \multicolumn{2}{|c|}{$\geq 25 \mathrm{mil}$} \\
\hline & & & EUA & BR & EUA & $\mathrm{BR}$ & EUA & BR & EUA & BR \\
\hline $\begin{array}{l}\text { Não adicionar outras } \\
\text { informações }\end{array}$ & 74,0 & 88,0 & 62,5 & 96,1 & 84,6 & 79,2 & 61,5 & 89,3 & 87,5 & 86,4 \\
\hline $\begin{array}{c}\text { Informações a serem } \\
\text { adicionadas }\end{array}$ & 26,0 & 12,0 & 37,5 & 3,9 & 15,4 & 20,8 & 38,5 & 10,7 & 12,5 & 13,6 \\
\hline Base & 50 & 50 & 24 & 26 & 26 & 24 & 26 & 28 & 24 & 22 \\
\hline $\begin{array}{c}\text { Alterar a apresentação/ } \\
\text { disposição das informações }\end{array}$ & 62,0 & 68,0 & 66,7 & 70,4 & 57,7 & 65,2 & 76,9 & 78,5 & 45,8 & 54,5 \\
\hline $\begin{array}{l}\text { Não alterar a apresentação/ } \\
\text { disposição das informações }\end{array}$ & 38,0 & 32,0 & 33,3 & 29,6 & 42,3 & 34,8 & 23,1 & 21,5 & 54,2 & 45,5 \\
\hline Base & 50 & 50 & 24 & 27 & 26 & 23 & 26 & 28 & 24 & 22 \\
\hline
\end{tabular}

\section{informações a serem adicionadas}

No Brasil, os entrevistados destacaram a necessidade de serem incorporadas as seguintes informações ao conteúdo informativo já existente nas embalagens de cereais. São elas: 
- pequeno "histórico" sobre a função/ ação dos nutrientes, principalmente das vitaminas, no organismo;

- texto esclarecendo o emprego de expressões técnicas (kilocalorias, calorias), ou ainda, de termos, recentemente, empregados pela mídia, por exemplo, "alimento funcional";

- sobre a incorporação de frutas ao cereal, os entrevistados gostariam que viesse um esclarecimento quanto ao tipo de processamento adotado (desidratação ou liofilização). Ainda, de acordo com os entrevistados, na liofilização haveria maior retenção de nutrientes;

- "dicas"/ pensamentos relativos à prática de atividades físicas (esporte, postura corporal, movimentos corretos no trabalho doméstico) salutares ao organismo.

Nos EUA, os entrevistados destacaram a necessidade de que fossem adicionadas as seguintes informações no rótulo das embalagens de cereais. São elas:

- exigência legal do "Federal Drugs Administration - FDA" para que os fabricantes esclareçam a composição química dos cereais, no que tange à incorporação de certos conservantes, acidulantes, entre outros;

- texto/ comentários sobre as consequências do consumo excessivo de açúcar no organismo;

- afixação do preço, pelo próprio fabricante, na embalagem. Isso facilitaria a identificação do valor a ser pago pelo cereal.

Referindo-se à faixa etária, identifica-se que os brasileiros entre 18 a 35 anos tenderam a citar mais a não adição de outras informações do que aqueles da faixa entre 36 a 50 anos, ressaltando-se que a proporção da não adição de outras informações foi muito superior à proporção das informações a serem adicionadas. Entre os norte-americanos as porcentagens foram relativamente diferentes. Aqueles incluídos na faixa etária de 36 a 35 anos tenderam a citar mais a não adição de outras informações do que aqueles situados na faixa etária de 18 a 35 anos.

\section{alterar a apresentação/ disposição das informações}

Dentre os pontos levantados em que seria necessária alguma alteração quanto à apresentação/ disposição das informações, os mais salientados pelos entrevistados brasileiros foram os seguintes:

- padronizar o local a ser impresso o item "prazo de validade". Além disso, os entrevistados estão insatisfeitos com a qualidade da impressão dessa informação (apagada ou borrada);

- na tabela nutricional, o consumidor gostaria que fossem adicionados exemplos "equivalência nutricional", isto é, menção de fontes alimentares substitutivas para cada nutriente especificado na tabela nutricional. Ainda, segundo os entrevistados, essa formatação da informação nutricional evitaria que o consumidor precisasse calcular o preenchimento de suas necessidades nutricionais;

- a relação de ingredientes deveria vir de forma mais destacada, de tal forma que o consumidor pudesse identificar, com nitidez, se na composição do cereal existe ou não algum elemento cujo consumo seja proibitivo na sua dieta alimentar; 
- destacar mais certas "chamadas"/ "splashes", por exemplo, teor reduzido de açúcar, ou ainda, o nome do fabricante. Para tal, os respondentes sugeriram mudanças gráficas como ampliação das letras, bem como a utilização de cores contrastantes com a cor do fundo do cartucho.

Nos EUA, os pontos destacados pelos entrevistados, em que seria necessária alguma alteração quanto à apresentação/ disposição das informações, foram os seguintes:

* mudança gráfica, ou seja, ampliação das letras que expressam a lista de ingredientes contidos no cereal, bem como aquelas inseridas na tabela nutricional;

- dificuldade para ler e localizar o item "prazo de validade". A qualidade da impressão não é satisfatória (apagada). Foi sugerido o emprego de cores contrastantes na impressão dessa informação;

* texto/ comentários sobre os benefícios gerados ao organismo com a ingestão de fibra presente na porção recomendada para o consumo.

Referindo-se à faixa etária, identifica-se que os brasileiros entre 18 a 35 anos tenderam a citar mais a alteração/ disposição das informações do que aqueles da faixa entre 36 a 50 anos, ressaltando-se que a proporção da alteração/ disposição das informações foi muito superior à proporção da não alteração da apresentação/ disposição das informações. Entre os norte-americanos as porcentagens foram relativamente semelhantes. Aqueles incluídos na faixa etária de 18 a 35 anos tenderam a citar mais a alteração/ disposição das informações do que aqueles situados na faixa etária de 36 a 35 anos.

\subsubsection{Papel do Serviço de Atendimento ao Consumidor - SAC das empresas produtoras de cereais matinais}

Conforme a Tabela 4.2.12, cabe enfatizar que, de maneira geral, os aspectos levantados pelos entrevistados foram significativamente destacados pelos consumidores brasileiros em comparação com os usuários norte-americanos de cereais matinais.

Todos os entrevistados, no Brasil, citaram aspectos referentes à "prestar informação"/ "esclarecer dúvidas" como um dos papéis do Serviço de Atendimento ao Consumidor - SAC. Nos EUA, a proporção foi de $70,0 \%$. Quanto ao aspecto "complementar informação impressa na embalagem", $94,0 \%$ dos brasileiros mencionaram esse item, enquanto nos EUA, a proporção foi de, apenas, 40,0\%. Além disso, no Brasil, 92,0\% dos entrevistados informaram aspectos sobre a "prestação de serviço" desempenhada pelo SAC das empresas produtoras de cereais matinais. Em relação aos entevistados norte-americanos, $74,0 \%$ foi a proporção encontrada.

\section{prestar informação/ escla recer dúvidas}

Dentre os itens mencionados pelos entrevistados, destacam-se os seguintes:

* processo de fabricação dos cereais; 
- detalhamento sobre a composição do produto (química/ ingredientes), bem como acerca do seu valor nutricional (tabela nutricional). De acordo com os entrevistados, esse esclarecimento auxiliaria o consumidor, que apresentasse alguma restrição alimentar, a tomar sua decisão pela compra ou não do cereal matinal;

- informar endereços dos pontos-de-venda que comercializam o produto;

- alternativas de consumo, entre elas, as receitas.

\section{complementar informação impressa na embalagem}

As situações exemplificadas pelos respondentes sobre a complementação de informações já impressas nas embalagens foram, praticamente, as mesmas que as já citadas para o papel "esclarecimento de dúvidas". Dessa forma, cabe destacar as seguintes situações em que os consumidores solicitam complementação de informação:

- "dicas" culinárias, por exemplo, receitas e formas alternativas de consumo do produto;

- processo de fabricação do produto;

- maiores esclarecimentos quanto ao aspecto saudável do produto ao organismo endossado/ apoiado por instituições ligadas à área de saúde. Por exemplo, foi citada a "American Heart Association";

- consumo adequado do produto por pessoas que apresentem restrições alimentares (diabetes, alergia) em sua dieta;

- detalhamento sobre determinados termos técnicos, por exemplo, glúten, kilocalorias versus calorias;

- endereços dos pontos-de-venda que comercializam o produto.

De acordo com a Tabela 4.2.12, cabe enfatizar que todos os brasileiros destacaram o aspecto "prestar informação"/ "esclarecer dúvidas" como um dos papéis do SAC. A concentração das respostas é verificada na faixa etária de até 35 anos $(100,0 \%)$. Quanto à renda individual anual, $100,0 \%$ dos entrevistados estão na faixa de maior poder aquisitivo. Conforme a mesma Tabela, entre os norte-americanos, verifica-se uma maior concentração das respostas na faixa etária de até 35 anos (43,5\%), Quanto à renda individual anual, as respostas concentraram-se na faixa de maior poder aquisitivo $(43,5 \%)$.

\section{prestar serviço}

O conceito de "prestação de serviço" atribuído, pelos entrevistados, ao SAC ficou restrito ao aspecto denominado "atender reclamação". Os respondentes destacaram como situações anormais, os seguintes problemas:

- produto mal acondicionado (embalagem danificada e/ou com defeito);

- presença de corpo estranho;

- alterações no sabor, na aparência (cor), ou ainda, na consistência ("murcho"). 
Tabela 4.2.12 Quantidade de respondentes que declararam o papel do "Serviço de Atendimento ao Consumidor - SAC" (valores em porcentagem)

\begin{tabular}{|c|c|c|c|c|c|c|c|c|c|c|}
\hline \multirow{3}{*}{ CITAÇÕES } & \multicolumn{2}{|c|}{ RESPOND. } & \multicolumn{4}{|c|}{ FAIXA ETÁRIA } & \multicolumn{4}{|c|}{ RENDA IND.ANUAL - US\$ } \\
\hline & \multirow[t]{2}{*}{ EUA } & \multirow[t]{2}{*}{ BRASIL } & \multicolumn{2}{|c|}{$18-35$ anos } & \multicolumn{2}{|c|}{$36-50$ anos } & \multicolumn{2}{|c|}{$<25 \mathrm{mil}$} & \multicolumn{2}{|c|}{$\geq 25 \mathrm{mil}$} \\
\hline & & & EUA & BR & EUA & BR & EUA & BR & EUA & BR \\
\hline $\begin{array}{l}\text { Prestar informação/ } \\
\text { esclarecer dúvidas }\end{array}$ & 70,0 & 100,0 & 75,0 & 100,0 & 65,4 & 100,0 & 66,7 & $\overline{100,0}$ & 73,1 & 100,0 \\
\hline Sem menções & 30,0 & 0 & 25,0 & 0 & 34,6 & 0 & 33,3 & 0 & 26,9 & $\mathbf{0}$ \\
\hline Base & 50 & 50 & 24 & 26 & 26 & 24 & 24 & 26 & 26 & 24 \\
\hline $\begin{array}{c}\text { Complementar informação } \\
\text { impressa na embalagem }\end{array}$ & 40,0 & 94,0 & 43,5 & 100,0 & 37,0 & 87,5 & 37,0 & 88,5 & 43,5 & 100,0 \\
\hline Sem menções & 60,0 & 6,0 & 56,5 & 0 & 63,0 & 12,5 & 63,0 & 11,5 & 56,5 & 0 \\
\hline Base & 50 & 50 & 23 & 26 & 27 & 24 & 27 & 26 & 23 & 24 \\
\hline Prestar serviço & 74,0 & 92,0 & 78,2 & 84,6 & 70,4 & 100,0 & 69,2 & 92,3 & 79,2 & 91,6 \\
\hline Sem menções & 26,0 & 8,0 & 21,8 & 15,4 & 29,6 & 0 & 30,8 & 7,7 & 20,8 & 8,4 \\
\hline Base & 50 & 50 & 23 & 26 & 27 & 24 & 26 & 26 & 24 & 24 \\
\hline
\end{tabular}

No Brasil, verifica-se uma maior concentração das respostas na faixa etária entre 36 a 50 anos $(100,0 \%)$. Em relação à renda individual anual, as respostas concentraram-se na faixa de menor poder aquisitivo. Nos EUA, observa-se uma maior concentração das respostas na faixa etária de até 35 anos $(78,2 \%)$, Quanto à renda individual anual, as respostas concentraram-se na faixa de maior poder aquisitivo $(79,2 \%)$.

\section{Visão Sistêmica}

\subsubsection{Relevância dos atributos impressos nas embalagens de cereais matinais}

Considerando-se todo o conjunto de citações apresentadas na Tabela 4.2.13, identificam-se evidências de que a quantidade de citações coincidentes com o modelo sistêmico (Castro, 1994) tende a ser diferente entre brasileiros e norte-americanos, devido ao fato do teste qui-quadrado ter sido significante ao nivel de $1 \%$.

Pela mesma Tabela, nota-se que a maior aderência ao modelo sistêmico tende a ser entre os brasileiros, visto que $38,0 \%$ deles foram classificados como tendo citado "18 ou mais" atributos coincidentes. Acrescenta-se além disso, que entre os norte-americanos a quantidade de atributos coincidentes concentrou-se na categoria "até 14 " citações, representando $52,0 \%$ dos casos. 
Tabela 4.2.13

Citações coincidentes

\begin{tabular}{l|c|c|c|c}
\hline \multirow{2}{*}{$\begin{array}{c}\text { CITAÇÕES } \\
\text { COINCIDENTES }\end{array}$} & \multicolumn{4}{|c}{ NACIONALIDADE } \\
\cline { 2 - 5 } & \multicolumn{2}{|c|}{ BRASILEIROS } & \multicolumn{2}{c}{ NORTE-AMERICANOS } \\
\hline até 14 & 16 & 32,0 & 26 & 52,0 \\
\hline de 15 a 17 & 15 & 30,0 & 24 & 48,0 \\
\hline acima de 18 & 19 & 38,0 & 0 & 0 \\
\hline
\end{tabular}

\subsubsection{Grau de aderência dos atributos ao modelo sistêmico}

Embora cientes da impossibilidade da aplicação de testes estatísticos de comparação de grupos, devido a não aleatoriedade e representatividade da amostra, ainda assim, preferiu-se utilizar a estatística quiquadrada em algumas situações de comparação. Destaca-se, no entanto, que a aplicação foi meramente referencial com a finalidade de eliminar o subjetivismo do pesquisador ao comparar dois valores supostamente entendidos como iguais ou diferentes. Nesse sentido, o teste, pelo menos, envolve uma análise sistemática e mecânica, eliminando uma possivel interferência do pesquisador. Dessa forma, quando o resultado final do teste revelar uma possível igualdade ou diferença das distribuições, a interpretação estará sendo conduzida no contexto de evidências da presença da primeira ou da segunda situação, sem se entender como um fato conclusivo.

Para verificar o grau de aderência dos atributos ao modelo sistêmico, os respondentes eram estimulados a opinar em relação a cada um dos atributos foco do estudo. Como a questão era aberta, os entrevistados podiam citar mais de um atributo constituinte do modelo sistêmico. Observa-se ainda, na Tabela 4.2.14 e no Gráfico 4.2.14a, que alguns atributos foram acrescentados pelos respondentes.

Com base nas declarações dos entrevistados, assumiu-se que o percentual de respostas favoráveis a cada atributo impresso nas embalagens de cereais matinais significou o grau de aderência do atributo ao modelo sistêmico. Considerando-se todo o conjunto de percentuais obtidos, para os dois grupos pesquisados, aplicou-se o teste qui-quadrado com a finalidade de se verificar eventuais diferenças no grau de aderência ao se considerar os dois grupos.

Após a aplicação do teste, que comparou dois a dois cada atributo, verificou-se que ao nível de significância de $1 \%$, as proporções de citações evidenciaram ser iguais para os atributos "expectativa/ embalagem típica do produto", "composição do produto/ ingredientes", "peso/ quantidade", "preço/ presença", "marca", "validade", "receitas", "cores", "símbolos/ figuras", "criatividade", "integridade do produto", "valor nutritivo", "recomendações de uso", "nome do produto", "splashes/ chamadas", "aditivos/ conservantes", "SAC - Serviço de Atendimento ao Consumidor", "e-mail" e "promoções/ brindes". 
Uma análise mais detalhada sobre a Tabela 4.2.14 revela elementos importantes que podem ser objeto de algumas considerações julgadas relevantes. Parte dessas considerações são advindas da análise contida no item "caracterização do perfil sócio-econômico do consumidor de cereais matinais", bem como acerca dos tópicos constituintes do item "embalagem". Essa análise foi dividida em dois grandes grupos:

* Grupo 1 - Proporções de citações tenderam a ser iguais entre brasileiros e norte-americanos.

* Grupo 2 - Proporções de citações tenderam a ser diferentes entre brasileiros e norteamericanos.

Grupo 1 - Proporções de citações tenderam a ser iguais entre brasileiros e norte-americanos

expectativa/ embalagem típica do produto e criatividade

Ninguém atribuiu relevância aos atributos "expectatival embalagem típica do produto" e "criativiadade" presentes nas embalagens de cereais matinais. Acredita-se que esse entendimento reflita o fato do consumo do produto estar associado aos hábitos culturais do consumidor. Assim, os entrevistados entenderam que as embalagens de cereais matinais são padronizadas e, portanto, não esperam muita variação em termos das alternativas oferecidas pelo mercado durante a sua comercialização.

\section{recomendações de uso}

Praticamente, todos os entrevistados não atribuíram relevância ao atributo "recomendações de uso". Segundo os norte-americanos, o cereal matinal é um alimento integrante da sua alimentação diária por compreender determinadas características denominadas básica e padrão. Para os brasileiros, o consumo do produto está relacionado à adoção de uma "filosofia de vida" de "culto ao corpo" e de valorização ao aspecto "funcional" do produto. As variações de opinião identificadas estão, basicamente, relacionadas com o aspecto cultural de cada país foco do presente estudo.

Acredita-se que os entrevistados não tenham dúvidas quanto à aplicação primária do cereal matinal. Não foi destacada a necessidade de se acrescentar informação esclarecedora sobre o uso específico do produto em questão.

\section{integridade do produto}

Cerca de 50,0\% dos entrevistados destacaram relevância para o item "integridade do produto". Os respondentes consideraram que essa informação é transmitida através dos elementos constituintes da foto na face principal da embalagem e, posteriormente, checada durante a etapa de consumo do cereal quando são verificadas as questões de consistência crocante e sabor típico (não alterado) do produto. 
Tabela 4.2.14 Grau de aderência dos atributos em relação ao modelo sistêmico

\begin{tabular}{l|c|c|c|c}
\hline \multirow{2}{*}{ ATRIBUTOS } & \multicolumn{2}{|c|}{ BRASIL } & \multicolumn{2}{c}{ EUA } \\
\cline { 2 - 5 } & ABS. & $\%$ & ABS. & $\%$ \\
\hline Constituintes do Modelo Sistêmico & & & & \\
\hline Expectativa/ embalagem típica do produto & 0 & 0 & 0 & 0 \\
\hline Preparo/ uso do produto & 01 & 2,0 & 12 & 24,0 \\
\hline Criatividade & 01 & 2,0 & 0 & 0 \\
\hline Recomendações de uso & 02 & 4,0 & 0 & 0 \\
\hline Reciclagem/ preocupação c/meio ambiente & 07 & 14,0 & 0 & 0 \\
\hline "Dicas"/melhor aproveitamento produto & 13 & 26,0 & 42 & 84,0 \\
\hline Unidade de consumo & 18 & 36,0 & 0 & 0 \\
\hline Finalidade/ objetivo & 21 & 42,0 & 01 & 2,0 \\
\hline Aplicação/ emprego do produto & 23 & 46,0 & 0 & 0 \\
\hline Integridade do produto & 29 & 58,0 & 24 & 48,0 \\
\hline Receitas & 30 & 60,0 & 26 & 52,0 \\
\hline Dinânmica/ visão global da embalagem & 31 & 62,0 & 0 & 0 \\
\hline Materia/ forma/ formato & 34 & 68,0 & 47 & 94,0 \\
\hline Código de barras & 38 & 76,0 & 0 & 0 \\
\hline Composição gráfica & 42 & 84,0 & 16 & 32,0 \\
\hline Logotipo & 45 & 90,0 & 25 & 50,0 \\
\hline Símbolos/ figuras & 45 & 90,0 & 45 & 90,0 \\
\hline Fabricante & 48 & 96,0 & 37 & 74,0 \\
\hline Valor nutritivo & 48 & 96,0 & 49 & 98,0 \\
\hline Composição do produto/ ingredientes & 49 & 98,0 & 50 & 100,0 \\
\hline Preço/ presença & 49 & 98,0 & 47 & 94,0 \\
\hline Peso/ quantidade & 50 & 100,0 & 45 & 90,0 \\
\hline Marca & 50 & 100,0 & 48 & 96,0 \\
\hline Validade & 50 & 100,0 & 49 & 98,0 \\
\hline Cores & 50 & 100,0 & 45 & 90,0 \\
\hline "Appeal"/ apelo visual & 50 & 100,0 & 0 & 0 \\
\hline Adicionados pelos Entrevistados & & & & \\
\hline Cupons & 0 & 0 & 35 & 70,0 \\
\hline Endosso/ instituições & 03 & 6,0 & 21 & 42,0 \\
\hline E-mail & 04 & 8,0 & 0 & 0 \\
\hline Promoçães/ brindes & 23 & 46,0 & 35 & 70,0 \\
\hline Aditivos/ conservantes & 31 & 62,0 & 21 & 42,0 \\
\hline Porções sugeridas & 45 & 90,0 & 30 & 60,0 \\
\hline SAC-serviço de atendimento ao consumidor & 45 & 90,0 & 42 & 84,0 \\
\hline Personagens & 47 & 94,0 & 25 & 50,0 \\
\hline Nome do produto & 50 & 100,0 & 49 & 98,0 \\
\hline "Splashes"/ chamadas & 50 & 100,0 & 50 & 100,0 \\
\hline
\end{tabular}

Nota: As hachuras destacam os atributos cujo teste de hipótese evidenciou igualdade na proporção de citações entre brasileiros e norte-americanos 
Gráfico 4.2.14a

Distribuição do grau de aderência dos atributos em relação ao modelo sistêmico (valores em porcentagem)

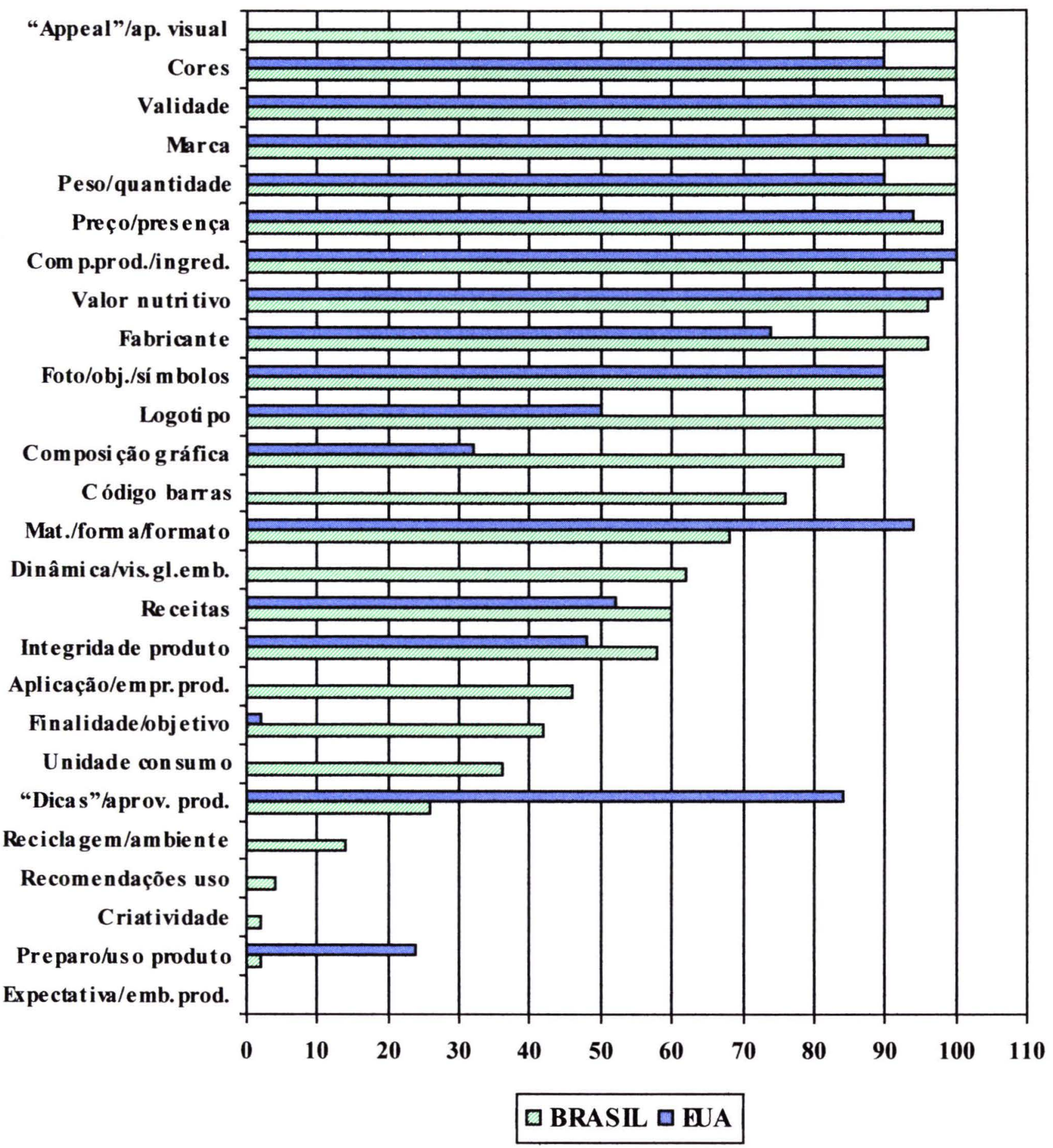




\section{receitas}

Em torno de 50,0\% dos entrevistados consideraram relevante a impressão do item "receitas" nas embalagens de cereais matinais. Com essa informação, os respondentes mencionaram a possibilidade de estarem variando as formas de aplicação e consumo do referido produto, principalmente, no tocante aos cereais denominados "Corn Flakes" e "Rice Krispies". O primeiro tem sido empregado, pelo consumidor brasileiro, na preparação de saladas, empanados e massas. $\mathrm{O}$ segundo vem sendo utilizado na preparação de sobremesas de mesmo nome, pelo consumidor norte-americano e de bombons, pelos brasileiros.

\section{símbolos/ figuras}

$90,0 \%$ dos entrevistados destacaram a relevância do item "símbolos/ figuras". Para os respondentes, a face principal da embalagem chama a atenção do consumidor para os principais ingredientes que entram na composição do produto. Diante da gôndola, o usuário identifica o tipo de cereal de sua preferência. A foto do próprio produto ("tigela com o cereal, leite, mel, frutas secas, castanhas") impressa na face principal do cartucho, desperta, naquele momento, a vontade no usuário em querer consumir o produto. Além disso, permite que o consumidor tenha uma idéia (aparência) acerca do conteúdo inserido na embalagem. Para o item "símbolos", por exemplo um coração, os entrevistados ressaltaram o emprego de instituições que endossam/ apoiam o consumo do produto, destacando seu lado benéfico à saúde do consumidor.

\section{valor nutritivo}

Praticamente todos os entrevistados ressaltaram a importância do item "valor nutritivo". De acordo com os respondentes, o aspecto "nutritivo"/ "saudável" está relacionado à composição do cereal. Com base na tabela nutricional impressa na embalagem do cereal matinal, o consumidor pode avaliar o produto em termos de sua composição (vitaminas, minerais, teor de gordura e de fibras, fornecimento de energia, entre outros) e, assim, tomar sua decisão ao adquirir aquele que atenda/ preencha às suas necessidades. Como exemplo de informações nutricionais extraídas da tabela nutricional foram mencionados teor reduzido de gordura/ "low fat", teor calórico, de vitaminas e/ou minerais.

\section{composição do produto/ ingredientes}

Cerca de $100,0 \%$ dos entrevistados consideraram que o item "composição do produto/ ingredientes" ajuda na tomada de decisão pela compra ou não do cereal matinal ofertado nos pontos-de-venda. $\mathrm{O}$ consumidor tem acesso a informações que dizem respeito, por exemplo, à presença ou não de açúcar na composição do produto, bem como àquelas relativas ao sabor (gostoso e variado) do cereal (chocolate, frutas, entre outras).

\section{preço/ presença e peso/ quantidade}

Praticamente a totalidade dos entrevistados ressaltou a relevância dos itens "preço/ presença" e "peso/ quantidade". O preço do cereal matinal foi considerado elevado em comparação com a barata matéria-prima empregada na elaboração do produto. Foi ressaltada, ainda, a baixa relação 
entre custo e beneficio (preço alto e rendimento reduzido) apresentada pelos cereais matinais. Assim, a impressão dos itens em questão permitem que o consumidor possa avaliar, dentre as alternativas ofertadas pelo mercado, aquela que atenda melhor às necessidades do usuário do produto.

\section{marca}

Cerca de 100,0\% dos entrevistados destacaram a relevância do item "marca". Para os respondentes, o consumidor de cereal matinal procura adquirir o produto cuja "marca" proporcione satisfação, ou seja, um cereal crocante, principalmente, quando for adicionado ao leite, sucos, entre outros. Pode-se dizer que o elemento "marca" está associado aos fatores confiança e tradição. Além disso, foram destacadas a arte gráfica (tamanho da letra, colorido) e logotipia (por exemplo, estilo da letra) empregadas na grafia do item "marca". Segundo os entrevistados, o visual resultante da arte gráfica empregada causa um impacto positivo, de tal forma que o consumidor possa, prontamente, identificar seu produto dentre os demais inseridos nas gôndolas dos pontos-de-venda.

\section{validade}

Em torno de $100,0 \%$ dos entrevistados consideraram relevante o item "validade". De acordo com os respondentes, é fundamental que o produto esteja sempre com sua consistência crocante. A quantidade de cereal matinal contida em uma embalagem de tamanho convencional é consumida por uma pessoa, em média, no prazo de uma semana. Verifica-se que esse produto apresenta uma alta rotatividade no seu consumo. Portanto, os entrevistados salientaram que procuram comprar o cereal matinal de sua preferência recentemente produzido, ou seja, que apresente data de fabricação bem recente.

\section{cores}

Para, praticamente, $100 \%$ dos consumidores entrevistados, a embalagem de cereais matinais facilita na identificação do produto por apresentar um colorido harmônico, vibrante e atraente típico de cada marca ofertada nos pontos-de-venda.

\section{promoçōes/ brindes}

Conforme o Gráfico 4.2.14b, em média, $50 \%$ dos entrevistados adicionaram e destacaram a relevância do item "promoções/ brindes". Segundo os respondentes, o consumidor de cereal matinal se sente atraído pela presença de elementos promocionais incorporados às embalagens dos cereais. Dentre as situações exemplificadas, destacam-se aquelas em que o fabricante coloca elementos (colher, tigela) que podem ser empregados, posteriormente e especificamente, para o próprio consumo do produto.

\section{aditivos/ conservantes}

Cerca de 50,0\% dos entrevistados acrescentaram e ressaltaram a importância do item "aditivos/ conservantes". De acordo com os respondentes, a incorporação de certos elementos como corantes 
e/ou aromatizantes é visto como um fator negativo, pois dão a conotação de um produto "artificial". Por exemplo, foi mencionado o cereal denominado comercialmente "Froot Loops". Para o consumidor, muitas vezes, não fica claro que os aditivos e conservantes empregados na elaboração dos cereais são substâncias naturais e não elementos químicos com efeitos nocivos ao nosso organismo.

\section{SAC - Serviço de Atendimento ao Consumidor e "E-mail"}

Em torno de $90,0 \%$ dos entrevistados adicionaram e destacaram a relevância do item "SAC Serviço de Atendimento ao Consumidor". Os respondentes consideraram que, por intermédio dessa informação, o usuário de cereal matinal pode entrar em contato com o produtor para obter maiores esclarecimentos sobre o produto e, sobretudo, manifestar seu descontentamento e fazer uma reclamação. Neste último caso, dentre os exemplos mencionados pelos entrevistados, cabe destacar o aparecimento de "corpo estranho" no interior da embalagem do cereal.

Ainda, em relação aos canais de comunicação entre produtor e consumidor, $8,0 \%$ dos brasileiros destacaram como relevante a impressão do endereço eletrônico ("e-mail") das empresas produtoras de cereais matinais. De acordo com esse grupo de respondentes, a incorporação dessa informação passa ao consumidor a idéia de uma empresa moderna e que se preocupa em facilitar o acesso do usuário com o agente produtor.

\section{nome do produto}

Praticamente, todos os entrevistados incorporaram o item "nome do produto" à relação de informações relevantes impressas nas embalagens de cereais matinais. Segundo os respondentes, esse elemento informativo encontra-se destacado em função da arte gráfica (tamanho da letra, colorido forte e vibrante) e da logotipia (estilo da letra) empregadas. Os entrevistados reconheceram que é uma estratégia, muitas vezes, para vincular o nome do cereal à foto do personagem impressa na embalagem do produto. Como exemplo, foi mencionado o cereal matinal denominado "Sucrilhos", no Brasil e "Frosted Flakes", pelos norte-americanos. A embalagem desse produto traz tradicionalmente a foto de um tigre que passou a ser, internacionalmente, reconhecido como o personagem - "Tony the Tiger".

\section{"splashes"/ chamadas}

Todos os consumidores entrevistados destacaram a relevância do item "splashes/ chamadas". Segundo os respondentes norte-americanos, o usuário de cereal matinal é atraído pela informação que destaca a presença de cupons conferindo desconto na compra de uma outra embalagem do referido produto. De acordo com os entrevistados brasileiros, tem crescido o número de consumidores que buscam o consumo de uma alimentação saudável. Assim, foram valorizadas as "chamadas" que destacam o teor de fibra, açúcar e/ou colesterol contido no cereal matinal. 
Gráfico 4.2.14b Distribuição do grau de aderência dos atributos adicionados pelos entrevistados (valores em porcentagem)

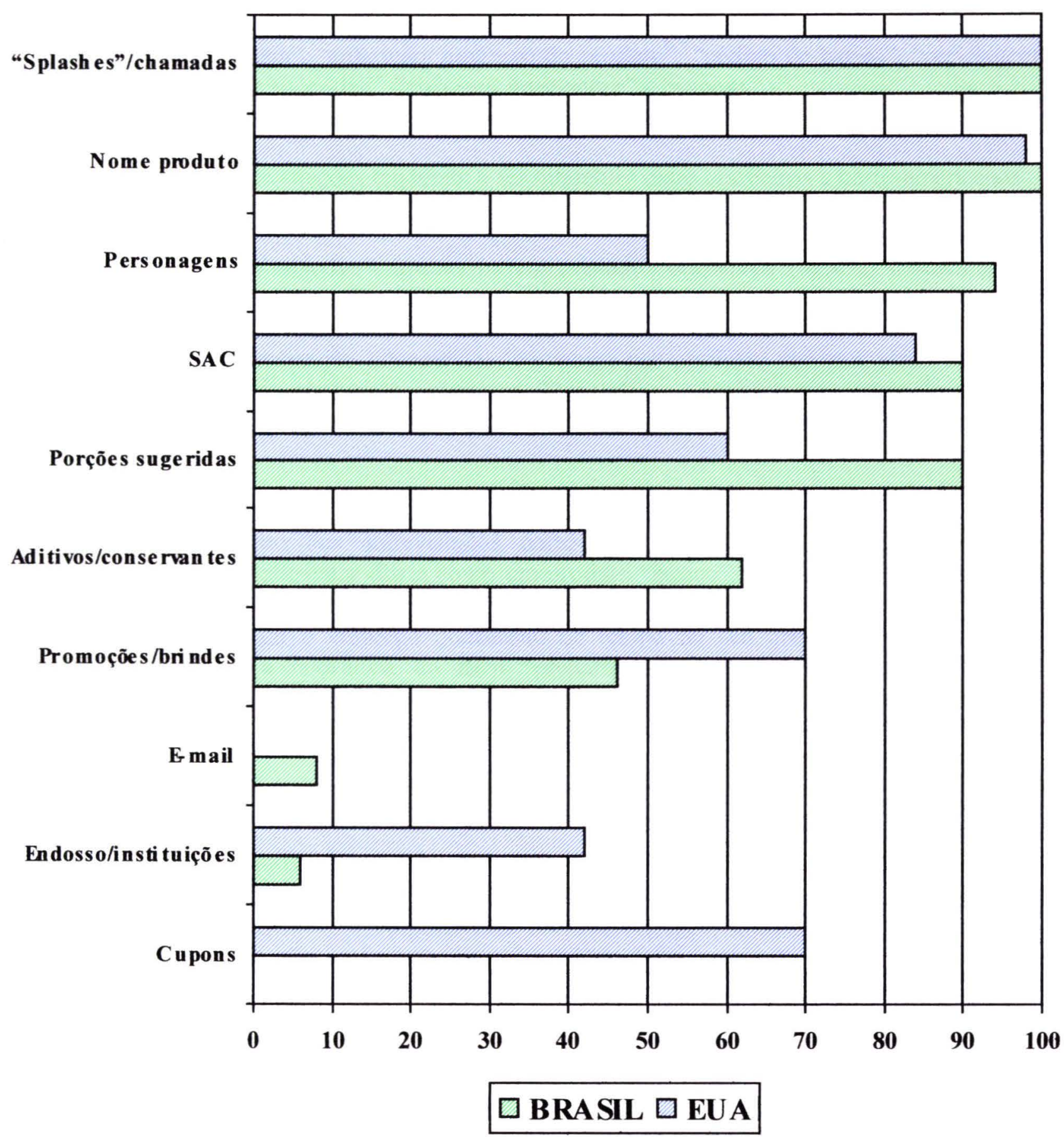


Ainda, segundo a Tabela 4.2.14 e o Gráfico 4.2.14a, após a aplicação do teste qui-quadrado, que comparou dois a dois cada atributo, verificou-se que ao nivel de significância de $1 \%$, as proporções de citações evidenciaram ser diferentes para os atributos "finalidade/ objetivo", "fabricante", "preparo/ uso do produto", "dicas/ melhor aproveitamento do produto", "logotipo", "material/ forma/ formato", "unidade de consumo", "composição gráfica", "appeal/ apelo visual", "dinâmica/ visão global da embalagem", "aplicação/ emprego do produto", "código de barras", "reciclagem", "personagens", "porções sugeridas", "endosso/ instituições" e "cupons".

Grupo 2 - Proporções de citações tenderam a ser diferentes entre brasileiros e norte-americanos

\section{finalidade/ objetivo e preparo/ uso do produto}

Para o item "finalidade/ objetivo", apenas os entrevistados brasileiros $(42,0 \%)$ destacaram sua relevância. Para os respondentes brasileiros o consumo do cereal matinal está relacionado à adoção de uma "filosofia de vida" de "culto ao corpo" e que valoriza o aspecto "funcional" do produto. Buscam ingerir uma alimentação diferenciada, composta por produtos naturais, ricos em fibra e com teores reduzidos de gordura e colesterol. Tomando-se por base esse entendimento, fica ressaltada a importância do item "finalidade/ objetivo" como fonte de informação para os brasileiros.

Segundo o entendimento dos entrevistados norte-americanos $(24,0 \%)$, o cereal matinal é incorporado à sua dieta alimentar diária como um produto "básico". Ou seja, além de alimentar e sustentar o indivíduo por longo espaço de tempo, é considerado saudável ao organismo e, sobretudo, por não exigir o emprego demasiado de tempo no seu preparo e consumo. Fica, portanto, reconhecida a relevânica do item "preparo/ uso do produto" para o grupo de respondentes norte-americanos. Acredita-se que as variações de opinião identificadas estão, basicamente, relacionadas com $o$ aspecto cultural de cada país.

\section{fabricante e logotipo}

De acordo com os dados apresentados na Tabela 4.2.14, observa-se que os entrevistados brasileiros atribuíram significativa relevância aos itens "fabricante" $(96,0 \%)$ e "logotipo" $(90,0 \%)$. Em relação ao entendimento dos respondentes norte-americanos, identificou-se que $50,0 \%$ dos entrevistados fizeram menção ao item "logotipo" e $74,0 \%$ foi a proporção encontrada para o item "fabricante".

Segundo o entendimento dos entrevistados, esses dois elementos informativos estão associados aos aspectos denominados tradição e confiança. Para o consumidor de cereal matinal, é importante que o fabricante seja conhecido do usuário no sentido de possuir experiência como agente produtor de cereais, ou pelo menos, de gêneros alimentícios. Consequentemente, o consumidor se sente mais confiante em adqurir o produto, que ele espera, atenda às suas necessidades. 
Acredita-se que a diferença observada, em termos de relevância atribuída pelos entrevistados aos itens em questão, esteja relacionada à diversificada gama de cereais ofertados aos consumidores norte-americanos, em comparação com a composição do mercado varejista brasileiro.

\section{“dicas"/ melhor aproveitamento do produto}

Quanto ao item "dicas"/ melhor aproveitamento do produto", destaca-se a relevância atribuida ao item pelos norte-americnaos $(84,0 \%)$. Visto ser um produto considerado "básico" em sua dieta alimentar diária, esse grupo de consumidores busca "dicas" no sentido de quebrar a monotonia que o consumo diário do produto possa trazer. Entre os brasileiros, a proporção foi de apenas $26,0 \%$.

\section{material/ forma/ formato}

Para os norte-americanos $(94,0 \%)$, a relevância do item "material/ forma/ formato" foi significativamente ressaltada. Entre os entrevistados brasileiros a proporção foi de apenas $68,0 \%$. De acordo com os entrevistados, as embalagens de cereais matinais comercializadas apresentam um visual padronizado. Ou seja, basicamente, o material empregado na elaboração de cartuchos e sacos plásticos é o mesmo, bem como a arte gráfica utilizada resulta em embalagens com forma/ formato bastante similares. Algumas alterações são identificadas pelos usuários de cereais matinais por ocasião de determinadas datas comemorativas (por exemplo, Copa do Mundo de Futebol), quando os fabricantes agregam aos personagens, das diversas marcas, elementos típicos do evento em destaque.

Provavelmente, a relevância atribuída ao item em estudo pelos norte-americanos esteja vinculada ao padrão de compra e consumo desses consumidores. Nos Estados Unidos, identificou-se que:

- os usuários diversificam o consumo do produto ao comprar, no mínimo, dois tipos diferentes de cereais;

- independentemente, do item estocagem, dão preferência às embalagens denominadas "tamanho familia", justamente, pelo intensificado consumo do produto.

\section{unidade de consumo}

Cabe destacar que $100,0 \%$ dos entrevistados norte-americanos não atribuíram relevância ao item "unidade de consumo". Levando-se em consideração o entendimento dos agentes de consumo e de produção entrevistados, acredita-se que os fatores mencionados a seguir tenham contribuído para o resultado obtido. São eles, a saber:

- a embalagem individual é uma forma "bem cara" de se comprar cereal;

- dentre os segmentos existentes para esse tipo de embalagem, destaca-se o do idoso. Na sua opinião, o cereal a ser consumindo estará sempre fresco e crocante;

- cidades em que o clima é muito úmido (por exemplo, Flórida), a existência de muitos insetos é uma decorrência da umidade do ar. A embalagem individual não requer cuidados específicos para garantir a preservação das características organolépticas do cereal. 
Por outro lado, em relação ao entendimento dos brasileiros, $36,0 \%$ dos entrevistados atribuíram relevância ao item "unidade de consumo". Foi constatado que, para a familia unicelular (consumidor que mora sozinho), a embalagem individual (unidade de consumo) é mais conveniente. $\mathrm{O}$ usuário terá acesso a um produto que estará sempre fresco e crocante, bem como poderá variar, com frequência, o tipo/ sabor do cereal matinal.

\section{dinâmica/ visão global da embalagem, composição gráfica e "appeal”/ apelo visual}

De acordo com os resultados apresentados na Tabela 4.2.14 e no Gráfico 4.2.14a, identificou-se destacada relevância para os itens "dinâmica/ visão global da embalagem" (62,0\%), "composição gráfica" $(84,0 \%)$ e "appeal"/ apelo visual $(100,0 \%)$ por parte dos entrevistados brasileiros. Entretanto, segundo o entendimento dos norte-americanos, somente ao item "composição gráfica" foi atribuída relevância por apenas $32,0 \%$ dos entrevistados.

Em relação aos elementos informativos mencionados anteriormente, os dados obtidos mostram que, no Brasil, o consumidor tende a ser mais influenciado pela aparência visual da embalagem de cereais matinais em comparação com o consumidor norte-americano. No geral, o brasileiro utiliza esse conjunto de informações para identificar o produto de sua preferência, e sobretudo, sente-se motivado pela aparência visual da embalagem no momento em adquirir um dado cereal matinal.

\section{aplicação/ emprego do produto}

Especificamente quanto ao item "aplicação/ emprego do produto", apenas os respondentes brasileiros $(46,0 \%)$ destacaram sua relevância. De acordo com esse grupo de entrevistados, o consumidor busca formas alternativas de aplicar o produto em sua alimentação diária com vista a torná-la mais saudável e nutritiva. Identificou-se um certo interesse por parte dos brasileiros em procurar, cada vez mais, utilizar o cereal matinal como um dos ingredientes na elaboração de preparações culinárias, tanto doces como salgadas. Esse resultado mostra uma certa tendência do consumidor norte-americano destacar mais o aspecto "praticidade/ rapidez", ao incorporar o cereal matinal em sua alimentação diária.

\section{código de barras e reciclagem/ preocupação com o meio ambiente}

Respectivamente, $76,0 \%$ e $14,0 \%$ dos brasileiros destacaram a relevância dos elementos informativos "código de barras" e "reciclagem/ preocupação com o meio ambiente" impressos nas embalagens de cereais matinais. Quanto ao entendimento dos norte-americanos, nenhum entrevistado fez menção aos atributos em estudo.

Os hábitos e padrão de consumo do norte-americano tendem a diferir em relação ao perfil do consumidor brasileiro. Acredita-se, também, que o consumidor norte-americano seja afetado pelos programas educativos desenvolvidos pelo "Food and Drug Administration - FDA", orgão que representa o sistema normativo de regulamentação do setor de rotulagem de produtos alimentícios e sua posterior comercialização, nos Estados Unidos. 


\section{personagens}

Ainda, de acordo com o Gráfico 4.2.14b, para ambos os grupos de consumidores entrevistados, a embalagem de cereais matinais facilita na identificação do produto por apresentar um colorido vibrante e atraente típicos de cada marca ofertada nos pontos-de-venda. Dos brasileiros que mencionaram o item "personagens", 94,0\% ressaltaram sua relevância. Entretanto, entre os norteamericanos a proporção foi de apenas $50,0 \%$.

\section{porções sugeridas}

De acordo com os dados apresentados na Tabela 4.2.14, 90,0\% dos brasieliros atribuíram relevância ao item "porções sugeridas" e entre os norte-americanos, a proporção encontrada foi de $60,0 \%$. Acredita-se que a importância atribuída pelos brasileiros ao item "porções sugeridas" esteja associada ao fato do consumo de cereais, no Brasil, estar associado a uma determinada "filosofia de vida", cujas pessoas valorizam o "culto ao corpo". Em compensação, nos Estados Unidos, o cereal matinal é visto como um produto "básico" a ser incorporado na dieta alimentar diária do norte-americano.

\section{endosso/ instituições}

Quanto à impressão do elemento informativo "endosso/ instituições" que recomendam e aprovam o consumo do cereal matinal, $42,0 \%$ dos norte-americanos destacaram sua relevância. Dentre os entrevistados brasileiros, a proporção foi de apenas $(6,0 \%)$. Nas embalagens dos cereais matinais comercializados nos Estados Unidos, a impressão dessa informação, que ressalta o aspecto benéfico do produto à saúde do consumidor, recebe um destaque especial em termos gráficos. Dessa forma, a informação não passa desapercebida pelo consumidor do referido produto.

\section{cupons}

Em relação ao item "cupons", apenas os entrevistados norte-americanos $(35,0 \%)$ acrescentaram e ressaltaram a relevância dessa informação impressa nas embalagens dos cereais matinais. Para esse grupo de consumidores, é bastante comum o emprego desse elemento informativo pelo mercado varejista. $O$ consumidor sente-se atraído a adquirir um dado cereal matinal, pois sabe que em sua próxima compra o preço do produto será reduzido de acordo com o valor oferecido e registrado na peça promocional incorporada à embalagem do mesmo. No Brasil, a mesma prática comercial ainda não ocorre com tanta frequência no mercado brasileiro. Portanto, a relevância do item em questão não foi verbalizada pelos entrevistados brasileiros.

\subsubsection{Classificação dos atributos}

Como a questão era aberta, os entrevistados podiam citar mais de um atributo considerado relevante no processo de tomada de decisão pela compra ou não de um dado cereal matinal. De acordo com a Tabela 4.2.15, os atributos mencionados pelos entrevistados foram classificados do primeiro ao quinto lugar. Os atributos constituintes do modelo sistêmico (Castro, 1994), bem como aqueles acrescentados pelos entrevistados foram dimensionados da seguinte forma: 
- primeiro lugar - os brasileiros destacaram os itens "integridade do produto" $(35,7 \%)$, "dinâmica/ visão global da embalagem" (43,8\%), "composição do produto/ ingredientes" $(52,1 \%)$, "cores" $(54,2 \%)$, "logotipo" $(68,8 \%)$, "unidade de consumo" $(100,0 \%)$ e personagens $(100,0 \%)$. Os elementos informativos "símbolos/ figuras", "valor nutritivo" e "splashes/ chamadas" foram, respectivamente, ressaltados pelos entrevistados brasileiros $(86,7 \%, 100,0 \%$, $77,8 \%)$ e norte-americanos $(33,3 \%, 37,5 \%, 30,4 \%)$. Em relação ao entendimento dos norteamericanos, destacaram-se os itens "validade" $(30,0 \%)$ e "material/ forma/ formato" $(100,0 \%)$.

- segundo lugar - os brasileiros deram relevância aos itens "validade" (44,7\%), "material/ forma/ formato" (30,0\%) e "integridade" $(50,0 \%)$. Apenas o elemento "peso/ quantidade" foi destacado por brasileiros $(37,2 \%)$ e norte-amereicanos $(33,3 \%)$. Segundo os norte-americanos, foram identificados relevantes os itens "marca" $(65,7 \%)$, "composição gráfica" $(50,0 \%)$, "preço/ presença" $(35,7 \%)$ e "cores" $(83,3 \%)$.

- terceiro lugar - neste nível de relevância, os entrevistados brasileiros ressaltaram os atributos "peso/ quantidade" (46,5\%), "marca" (50,0\%), "fabricante" (45,2\%), "preço/ presença" (44,9\%), "appeal"/ apelo visual (71,5\%) e "nome do produto" $(59,5 \%)$. Os norte-americanos destacaram os itens "receitas" $(50,0 \%)$, "validade" (30,0\%), "composição do produto/ ingredientes" $(32,6 \%)$, "símbolos/ figuras" (58,3\%), "valor nutritivo" $(37,5 \%)$ e "cupons" $(40,0 \%)$.

- quarto lugar - segundo os brasileiros, destacaram-se os elementos informativos "receitas" $(100,0 \%)$, "material/ forma/ formato" $(45,0 \%)$, "dinâmica/ visão global da embalagem" $(56,3 \%)$, "cores" $(37,5 \%)$ e "SAC" $(100,0 \%)$. Quanto aos norte-amereicanos, os atributos considerados relevantes foram "peso/ quantidade" $(66,7 \%)$, "cupons" $(60,0 \%)$ e "splashes"/ chamadas $(30,4 \%)$.

- quinto lugar - os atributos destacados pelos brasileiros foram "composição gráfica" $(57,5 \%)$ e "logotipo" $(31,3 \%)$. Para os norte-americanos, o atributo que mais se destacou foi "receitas" $(50,0 \%)$.

Ainda, tomando-se por base os dados apresentados na Tabela 4.2.15, verificou-se que o consumidor brasileiro tende a manisfestar/ expressar com maior facilidade seu comportamento durante o processo de tomada de decisão em relação à aquisição de cereais matinais, quando comparado ao do norte-americano.

Uma análise mais detalhada sobre a mesma Tabela, revela aspectos importantes que podem ser objeto de algumas considerações julgadas relevantes. Parte dessas considerações são advindas da análise acerca dos tópicos constituintes do item "embalagem". Nesse sentido, os comentários referem-se, apenas, aos valores classificados em primeiro lugar, iguais e/ou superiores a $30,0 \%$.

\section{integridade do produto}

De acordo com o Gráfico 4.2.15a, dos brasileiros que mencionaram o item "integridade do produto", $35,7 \%$ consideraram-no de significativa relevância na tomada de decisão pela compra ou não do cereal matinal. De acordo com o entendimento dos entrevistados, o cereal contido no 
interior do invólucro deve ser compatível com a foto do produto apresentada na face principal da embalagem.

Como característica fundamental dos cereais matinais foi ressaltada sua consistência crocante. Aliado a esse fator, os entrevistados destacaram o aspecto denominado "sabor". Identificou-se que os brasileiros percebem, por menor que seja, uma alteração ocorrida no sabor típico de uma dada categoria do produto.

\section{dinâmica/ visão global da embalagem}

Em relação ao item "dinâmica/ visão global da embalagem", dos entrevistados que mencionaram o elemento informativo, $43,8 \%$ dos brasileiros deixariam de comprar um dado cereal matinal caso a aparência global da embalagem do produto apresentasse algum senão que comprometesse a imagem do conteúdo nela inserido. Como senões foram citados os exemplos: embalagem amassada, com o fecho violado, entre outros.

\section{composição do produto/ ingredientes}

Para os brasileiros que mencionaram o item "composição do produto/ ingredientes", 52,0\% destacaram sua relevância. Observou-se que a identificação do "sabor" (chocolate, banana, entre outros), dentre os elementos que fazem parte da lista de ingredientes do produto, é um fator preponderante no momento em que o consumidor toma sua decisão pela compra ou não do cereal matinal. Por exemplo, se o consumidor não gostar de amendoim, e este último fizer parte da composição do cereal, ele deixará de comprar o produto.

\section{cores}

Em relação ao item "cores", dos entrevistados que mencionaram o elemento informativo, $54,2 \%$ dos brasileiros destacaram sua relevância. Dentre as alternativas ofertadas pelo mercado, o consumidor identifica o cereal matinal de sua preferência por intermédio do colorido impresso na embalagem do produto. Por exemplo, o cereal matinal denominado "Sucrilhos" é associado às cores azul escuro (fundo da embalagem), branco (nome comercial do produto) e laranja escuro (foto do personagem - tigre). 
Tabela 4.2.15 Classificação dos atributos (valores em porcentagem)

\begin{tabular}{|c|c|c|c|c|c|c|c|c|c|c|c|c|}
\hline \multirow[b]{2}{*}{ ATRIBUTOS } & \multirow{2}{*}{$\frac{\mathrm{N}}{\mathrm{ABS} .}$} & \multicolumn{5}{|c|}{ BRASIL } & \multirow{2}{*}{$\frac{\mathrm{N}}{\mathrm{ABS}}$} & \multicolumn{5}{|c|}{ EUA } \\
\hline & & $1^{\circ}$ & $2^{\circ}$ & $3^{\circ}$ & $4^{\circ}$ & $5^{\circ}$ & & $1^{\circ}$ & $2^{\circ}$ & $3^{\circ}$ & $4^{\circ}$ & $5^{\circ}$ \\
\hline \multicolumn{13}{|l|}{ Modelo Sistêmico } \\
\hline Receitas & 05 & 0 & 0 & 0 & 100,0 & 0 & 10 & 0 & 0 & 50,0 & 0 & 50,0 \\
\hline Validade & 47 & 6,4 & 44,7 & 29,8 & 19,1 & 0 & 10 & 30,0 & 20,0 & 30,0 & 20,0 & 0 \\
\hline Peso/ quantidade & 43 & 11,6 & 37,2 & 46,5 & 4,7 & 0 & 06 & 0 & 33,3 & 0 & 66,7 & 0 \\
\hline Marca & 48 & 12,5 & 10,4 & 50,0 & 16,7 & 10,4 & 35 & 5,7 & 65,7 & 5,7 & 22,9 & 0 \\
\hline Fabricante & 42 & 14,3 & 16,7 & 45,2 & 11,9 & 11,9 & 42 & 0 & 0 & 0 & 0 & 0 \\
\hline Composição gráfica & 40 & 17,5 & 0 & 20,0 & 5,0 & 57,5 & 14 & 0 & 50,0 & 14,3 & 7,1 & 28,6 \\
\hline Material/ forma/ formato & 20 & 25,0 & 30,0 & 0 & 45,0 & 0 & 05 & 100,0 & 0 & 0 & 0 & 0 \\
\hline Preço/ presença & 49 & 22,4 & 28,6 & 44,9 & 4,1 & 0 & 42 & 14,3 & 35,7 & 11,9 & 26,2 & 11,9 \\
\hline "Appeal"/ apelo visual & 35 & 22,9 & 0 & 71,5 & 5,7 & 0 & 0 & 0 & 0 & 0 & 0 & 0 \\
\hline Integridade do produto & 14 & 35,7 & 50,0 & 0 & 14,3 & 0 & 01 & 0 & 0 & 100,0 & 0 & 0 \\
\hline Dinâmica/ visão gl. emb. & 16 & 43,8 & 0 & 0 & 56,3 & 0 & 0 & 0 & 0 & 0 & 0 & 0 \\
\hline Compos. prod./ ingred. & 48 & 52,1 & 20,8 & 27,1 & 0 & 0 & 43 & 24,0 & 19,5 & 40,5 & 16,0 & 0 \\
\hline Cores & 24 & 54,2 & 0 & 0 & 37,5 & 8,3 & 06 & 0 & 83,3 & 0 & 16,7 & 0 \\
\hline Logotipo & 16 & 68,8 & 0 & 0 & 0 & 31,3 & 0 & 0 & 0 & 0 & 0 & 0 \\
\hline Símbolos/ figuras & 15 & 86,7 & 0 & 0 & 0 & 13,3 & 12 & 33,3 & 0 & 58,3 & 0 & 8,3 \\
\hline Unidade de consumo & 05 & 100,0 & 0 & 0 & 0 & 0 & 05 & 0 & 0 & 0 & 0 & 0 \\
\hline Valor nutritivo & 35 & 100,0 & 0 & 0 & 0 & 0 & 40 & 37,5 & 2,5 & 37,5 & 7,5 & 15,0 \\
\hline \multicolumn{13}{|l|}{ Adicionados } \\
\hline SAC-serv.atend.consum. & 14 & 0 & 0 & 0 & 100,0 & 0 & 0 & 0 & 0 & 0 & 0 & 0 \\
\hline Cupons & 0 & 0 & 0 & 0 & 0 & 0 & 05 & 0 & 0 & 40,0 & 60,0 & 0 \\
\hline Promoçōes/brindes & 07 & 0 & 85,7 & 0 & 0 & 14,3 & 0 & 0 & 0 & 0 & 0 & 0 \\
\hline Nome do produto & 42 & 9,5 & 4,8 & 59,5 & 11,9 & 14,3 & 0 & 0 & 0 & 0 & 0 & 0 \\
\hline "Splashes"/ "chamadas" & 45 & 77,8 & 0 & 4,4 & 6,7 & 11,1 & 23 & 30,6 & 22,2 & 0 & 30,6 & 16,6 \\
\hline Personagens & 16 & 100,0 & 0 & 0 & 0 & 0 & 0 & 0 & 0 & 0 & 0 & 0 \\
\hline
\end{tabular}

Nota: As hachuras destacam os atributos classificados de primeiro a quinto lugar e que apresentam percentagem igual ou superior a $30,0 \%$ 
Gráfico 4.2.15a Distribuição da classificação dos atributos, segundo os brasileiros (valores em porcentagem)

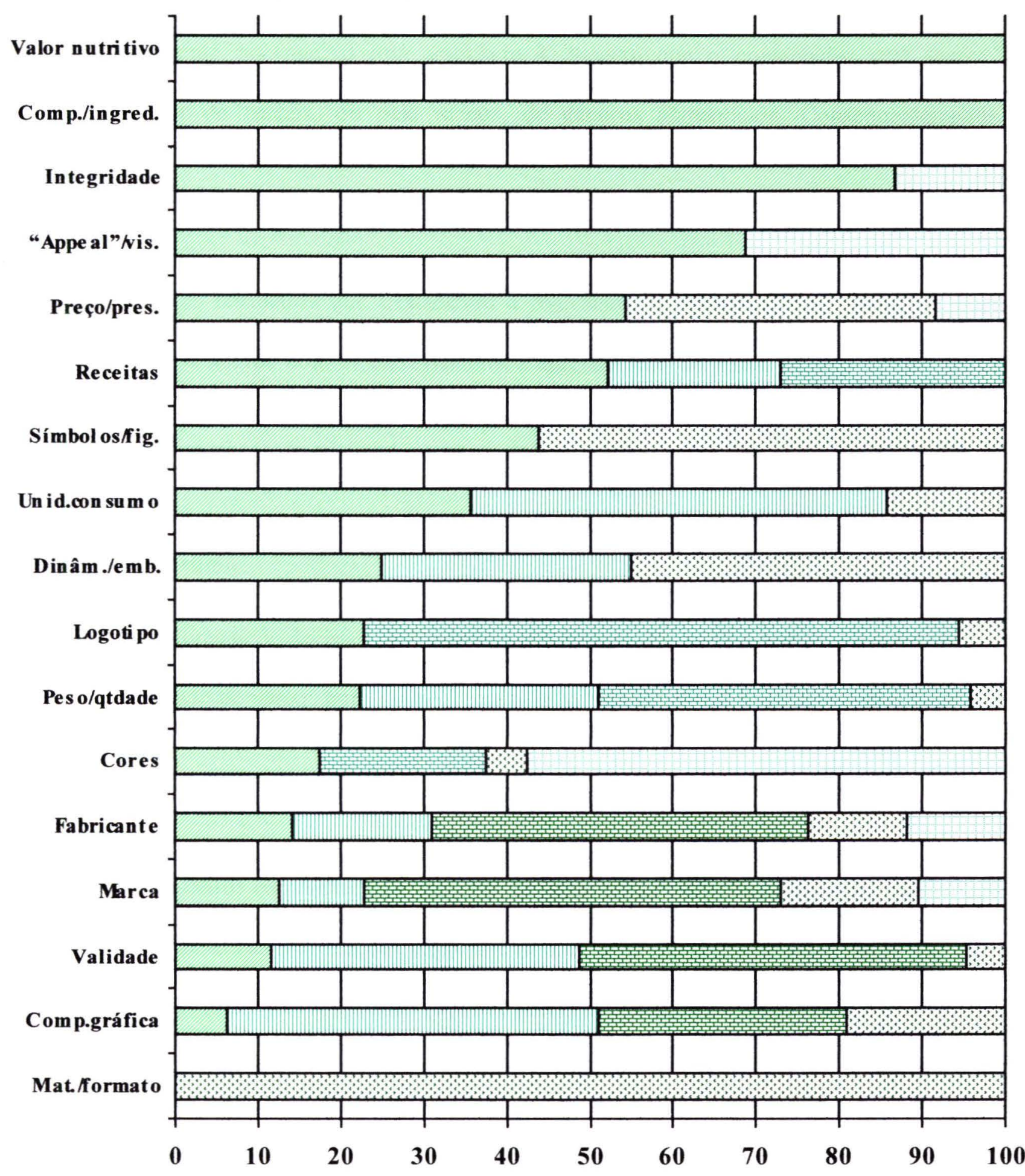

I 10 LUGAR $\square$ 2O LUGAR $\square$ 3o LUGAR $\square$ 4o LUGAR $\square$ 5o LUGAR 


\section{logotipo}

Para os brasileiros que mencionaram o item "logotipo", $68,8 \%$ ressaltaram sua relevância no momento em que o consumidor toma sua decisão pela compra ou não do cereal matinal. Observouse que o elemento informativo está associado à imagem que o consumidor tem acerca do fabricante. Ou seja, é importante que o fabricante tenha uma certa experiência (tradição) como agente produtor de cereais, ou pelo menos, de gêneros alimentícios. Consequentemente, o consumidor se sentirá mais confiante em adqurir o produto, que ele espera, atenda às suas necessidades.

\section{símbolos/ figuras}

Dos respondentes brasileiros que destacaram a relevância do elemento informativo "símbolos/ figuras", o percentual encontrado foi de $\mathbf{8 6 , 7 \%}$. Para os norte-americanos, a proporção foi de apenas $33,3 \%$. De acordo com os entrevistados, a apresentação do cereal matinal na face principal da embalagem foi considerada um dos itens de fundamental importância no processo de tomada de decisão. O conjunto de elementos, como por exemplo, a foto do próprio cereal, de frutas (desidratadas, castanhas), do mel, entre outros, despertam no consumidor o "appetite appeal", isto é, a vontade de comer o produto.

\section{unidade de consumo}

Dos brasileiros que mencionaram o item "unidade de consumo", 100,0\% destacaram sua relevância no processo de tomada de decisão. Segundo o entendimento dos respondentes, a familia unicelular (consumidor que mora sozinho) dá preferência por embalagens menores e/ou individuais. Assim, tem a possibilidade de variar, com maior frequência, o tipo de cereal a ser adquirido, bem como, está sempre consumindo um produto considerado "fresquinho", ou seja, crocante.

\section{valor nutritivo}

Conforme os Gráficos 4.2.15a e 4.2.15b, foi destacada a relevância do item "valor nutritivo" por $100,0 \%$ dos brasileiros entrevistados e que mencionaram o elemento informativo em questão. Para os norte-americanos, a proporção foi de apenas 37,5\%. Antes de adquirir o cereal matinal, os entrevistados analisam as informações impressas na área denominada "box nutricional" ou "tabela nutricional". Dentre as informações relativas ao valor nutricional do produto, foram ressaltadas aquelas relacionadas aos teores calórico (açúcar, gordura) e vitamínico encontrados na composição do cereal matinal. Das alternativas ofertadas pelo mercado, segundo os entrevistados, o consumidor tende a comprar o cereal matinal que contenha menor teor calórico. 


\section{validade}

De acordo com o Gráfico 4.2.15b, dos norte-americanos que mencionaram o elemento informativo "validade", $30,0 \%$ destacaram sua relevância no processo de tomada de decisão no momento de compra ou não de um dado cereal. Segundo o entendimento dos respondentes, o consumidor do produto dá preferência àquele recentemente fabricado. Para o usuário, é muito importante consumir um cereal frequentemente "fresquinho", ou seja, crocante.

\section{material forma/ formato}

O item "material/ forma/ formato" foi destacado relevante no processo de tomada de decisão por $100,0 \%$ dos norte-americanos entrevistados e que mencionaram o elemento informativo em questão. De acordo com os respondentes, antes de adquirir o cereal matinal, o usuário analisa a embalagem do produto, no geral. Avalia sua aparência visual (conjunto harmônico entre arte gráfica e material empregado), bem como considera sua formal formato que precisa estar em conformidade com a área de armazenagem (despensa) na residência do consumidor.

\section{"splashes"/ chamadas}

De acordo com o Gráfico 4.2 .15 , observa-se que brasileiros $(77,8 \%)$ e norte-americanos $(30,4 \%)$ consideraram relevante o item "splashes"/ "chamadas" no processo de tomada de decisão pela compra ou não de cereais matinais. Para os entrevistados, por intermédio da informação, por exemplo, "sem açúcar", o consumidor, além de ter uma idéia do teor calórico do cereal, tem condições de fazer opção por aquele que atenda melhor às suas necessidades, ou seja, por um produto menos ou mais calórico. Nesse sentido, ainda de acordo com os entrevistados, o elemento informativo é empregado como um item de significativa relevância no momento de escolha e aquisição de um dado cereal matinal.

\section{personagens}

Dos brasileiros que mencionaram o item "personagens", 100,0\% deles destacaram a influência exercida pelo elemento informativo sobre o consumidor no momento de compra do cereal matinal. Por exemplo, a foto do tigre denominado "Tony the Tiger", imediatamente, leva o consumidor a fazer a associação entre o personagem e o cereal matinal de marca "Sucrilhos". De acordo com o entendimento dos entrevistados, muitas vezes, o consumidor adquire um dado tipo de cereal matinal em função da imagem guardada em sua memória e, consequentemente, associada à época (sua infầncia) em que se deu o início do consumo do produto. 
Gráfico 4.2.15b Distribuição da classificação dos atributos, segundo os norte-americanos (valores em porcentagem)

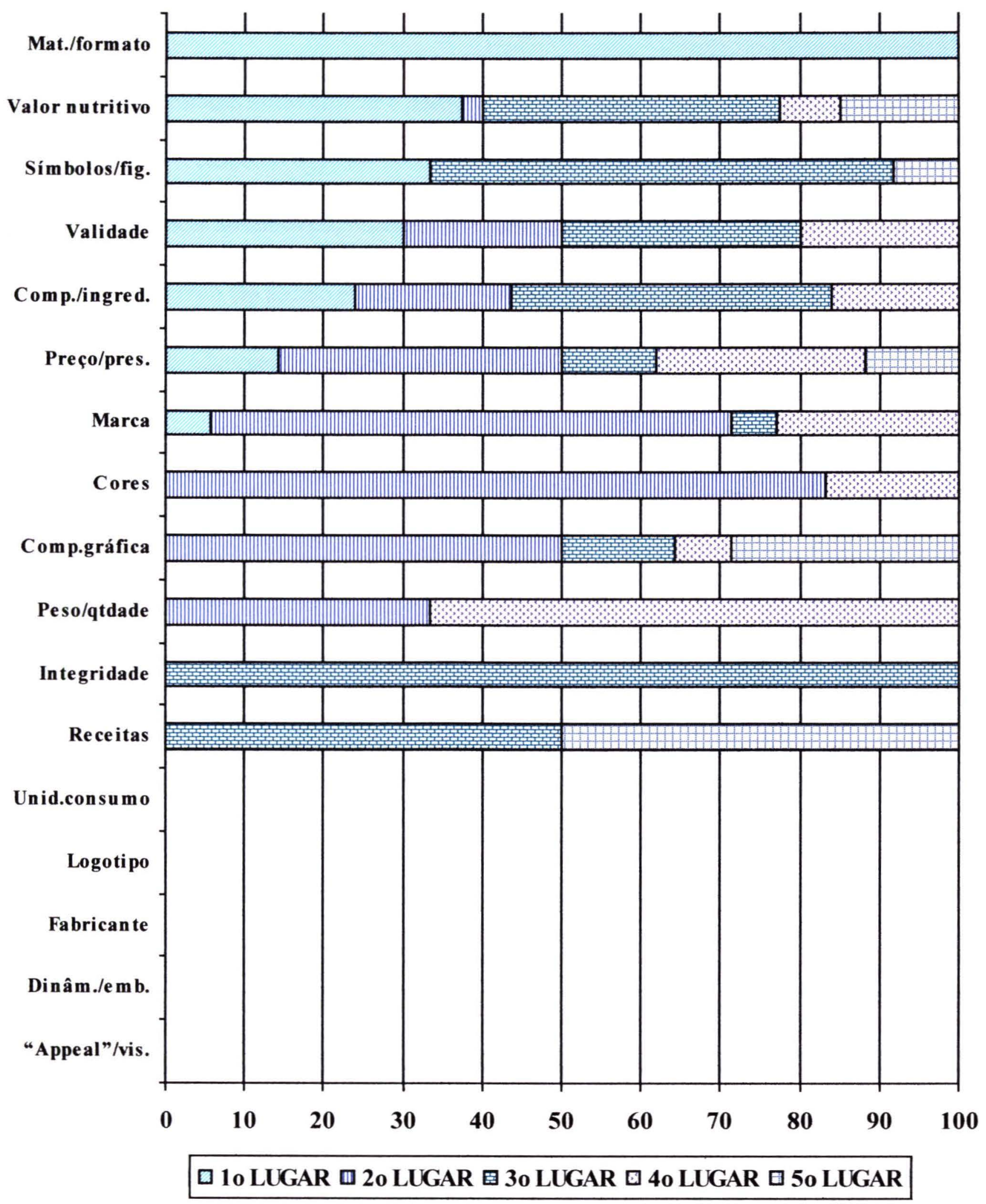


Conforme o que foi observado sobre o entendimento dos entrevistados brasileiros e norteamericanos, foram identificadas algumas similaridades e diferenças durante o desenvolvimento do presente estudo. Em relação aos pontos em comum destacados pelos entrevistados cabe destacar que o cereal matinal é visto:

- como um gênero alimentício;

- compreende características básicas e padrão (produto saudável, praticidade, entre outros);

- e confere "poder de saciedade" - vinculado à presença de fibras nos cereias.

Quanto às diferenças identificadas, ressaltam-se os seguintes aspectos:

- perfil do consumidor - cada grupo de entrevistados adota um estilo de vida ("filosofia de vida"), que acaba gerando um padrão específico de consumo de cereais matinais;

- nivel sócio-econômico, cultural e de educação exercem certa influência sobre o consumidor quanto ao procedimento de compra e consumo do produto objeto de estudo.

Uma análise mais detalhada sobre o entendimento dos agentes de produção revela elementos importantes que podem ser objeto de algumas considerações julgadas relevantes e que serão apresentadas no próximo tópico. 
Gráfico 4.2.15c Distribuição da classificação dos atributos adicionados, segundo os entrevistados (valores em porcentagem)

BRASIL

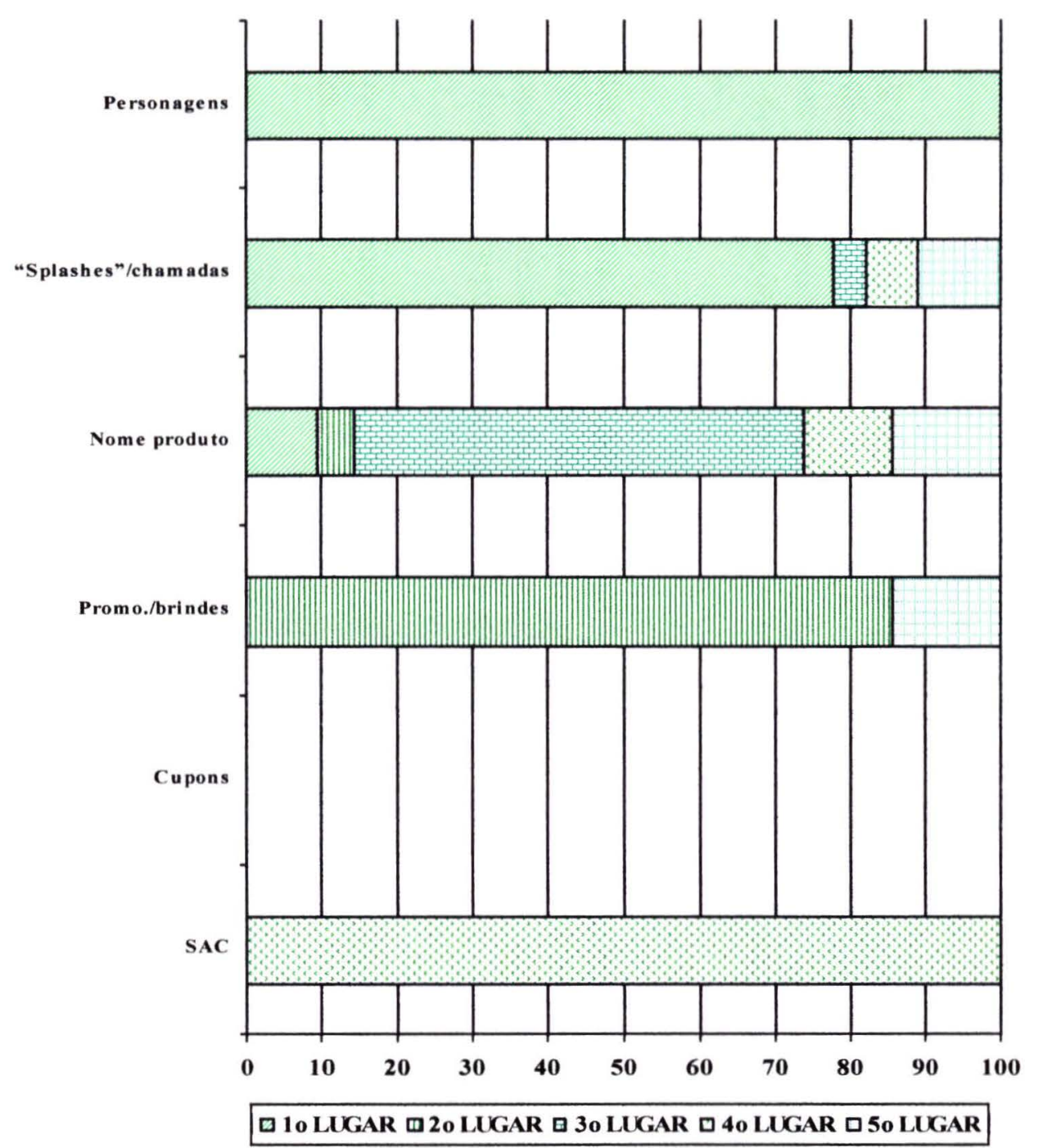

EUA

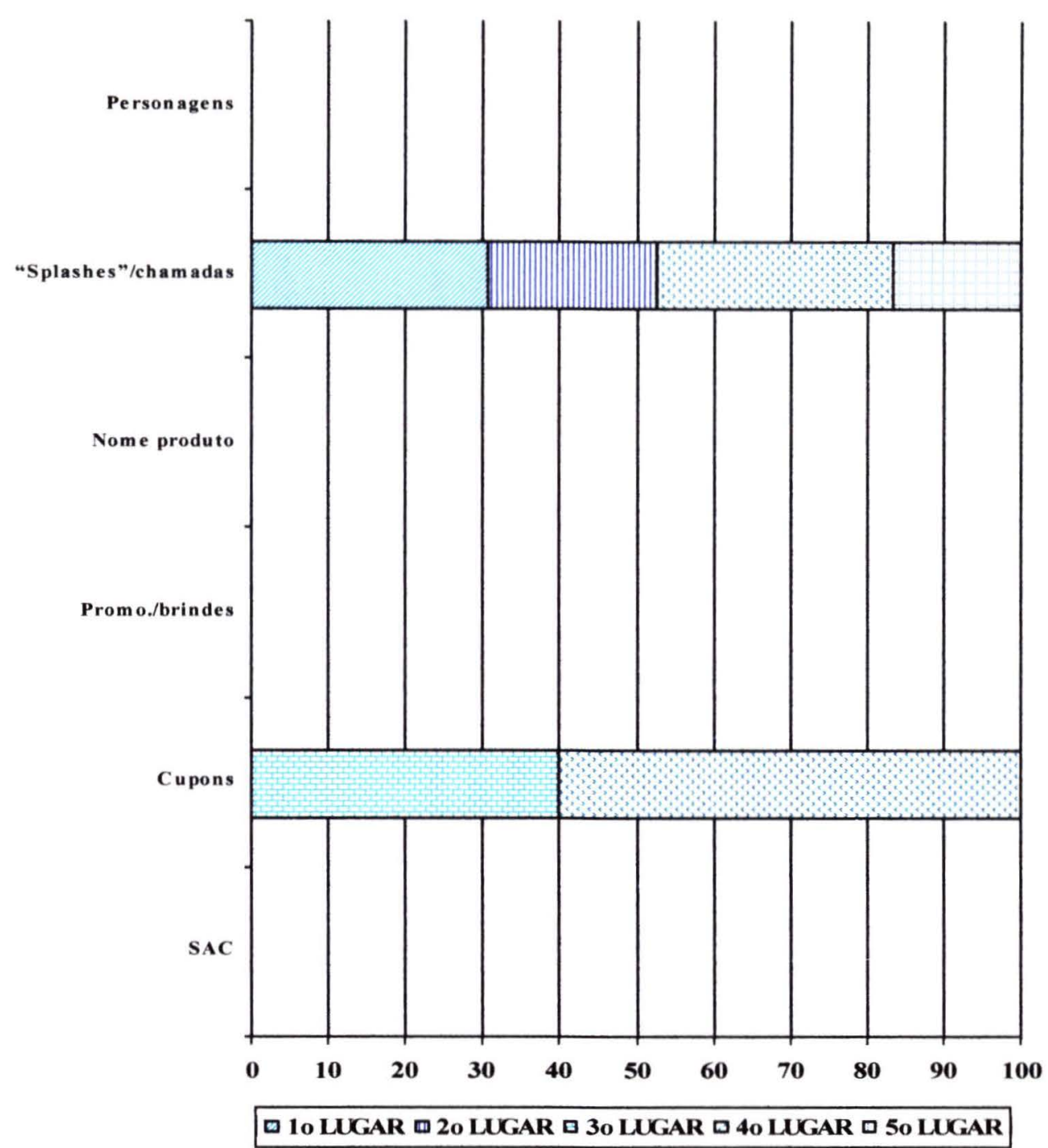




\subsection{Estudo com Empresa Norte-Americana e Brasileira Produtora de Cereais Matinais}

Para a realização desta etapa da pesquisa, foram mantidos contatos com profissionais de uma empresa alimentícia produtora de cereais matinais - Kellogg - de origem norte-americana, sediada na cidade de Battle Creek, estado de Michigan e que, também possue linha de produção e comercialização do referido gênero alimentício no Brasil, no município de São Paulo.

O objetivo do referido estudo abordou o conteúdo informativo das embalagens de cereais matinais. Procurou-se identificar e aprofundar o conhecimento comparado sobre o processo de tomada de decisão, segundo a ótica brasileira e norte-americanan dos agentes de produção, mais especificamente, dos profissionais envolvidos no processo de planejamento e desenvolvimento das embalagens de cereais matinais. Durante a realização do estudo não foi possivel entrevistar todos os profissionais envolvidos no processo de planejamento e desenvolvimento das embalagens de cereais matinais.

Para caracterizar o entendimento empresarial norte-americano acerca do conteúdo informativo das embalagens de cereais matinais foi entrevistada a diretora do Departamento Embalagem e Serviços de Impressão ("Packaging \& Printing Services"). Anteriormente, a respondente atuou na área denominada Estratégia de Planejamento ("Strategy of Planning"). Quanto à ótica brasileira dos agentes de produção do referido item alimentício, levou-se em consideração as opiniões emitidas pelo gerente de produto do Departamento de Marketing da companhia produtora de cereais matinais no Brasil.

Esses profissionais mostraram um amplo conhecimento acerca de todas as etapas envolvidas na elaboração das embalagens de cereais. Dessa forma, não só foi possível identificar a interdependência existente entre as atribuições identificadas nessa categoria de produto alimentício, segundo a proposição sistêmica empregada pela pesquisadora, bem como reconhecer 0 entendimento dos agentes produtores brasileiro e norte-americano quanto ao papel desempenhado pelo conjunto de informações inserido nas embalagens de cereais durante o processo de comercialização.

A realização das entrevistas ocorreu durante a jornada normal de trabalho dos profissionais entrevistados. Não foram encaminhados formulários, previamente, para a obtenção posterior dos dados. Informações complementares foram adquiridas por intermédio de correspondências eletrônicas pela Internet e/ou por telefone, quando necessárias.

Cabe ressaltar que os comentários apresentados em itálico e entre aspas representam a própria fala dos respondentes. 


\subsubsection{Empresa norte-americana produtora de cereais matinais}

\subsubsection{Processo de desenvolvimento da embalagem}

Aplicando-se o roteiro de entrevista, verificou-se que a empresa norte-americana adota um processo de planejamento e desenvolvimento das embalagens de cereais matinais, que pode ser enquadrado no esquema da visão sistêmica empregada pela pesquisadora. Foi identificada uma sequência de seis passos, que contam com a atuação integrada dos profissionais envolvidos no processo de elaboração das embalagens de cereais matinais: principais influenciadores, recomendações/ alternativas e avaliação, pesquisa; avaliação e produção, avaliação e veto, arte final, "feedback".

\section{Passo 1. Principais Influenciadores}

Segundo a respondente, há poucos grupos envolvidos no processo de planejamento e desenvolvimento das embalagens de cereais matinais. O Departamento de Marketing foi considerado como sendo o principal influenciador no processo de elaboração de embalagens. Agregado a esse Departamento, encontra-se o de Finanças, originariamente denominado "Equity Development". Cabe a essas duas áreas da empresa norte-americana o destacado papel relacionado ao "posicionamento da marca" perante o consumidor e, sobretudo, "da própria marca em si".

Os profissionais dos Departamentos de Marketing, Vendas e de Desenho e Impressão da Embalagem, ainda segundo a respondente, possuem um papel destacado no processo de planejamento e desenvolvimento das embalagens de cereais matinais. A seguir serão destacados os aspectos básicos identificados no processo de elaboração das embalagens de cereais matinais.

- Maquinaria e Logística: estas etapas foram consideradas padrão pela respondente. Quanto ao aspecto logística, raramente, há uma modificação. Ocorre em situações especiais, como por exemplo, no caso do produto denominado "Breakfastmate". Esse produto vem a ser a venda combinada de iogurte e cereal. Nesse caso, há a necessidade de se localizar um distribuidor específico. A embalagem é diferente, o produto é diferente e requer uma atenção especial (transporte/ conservação) e um distribuidor apropriado ao binômio produto/ embalagem.

- Aparência: o desenho da embalagem em si está relacionado com a aparência, bem como com a comunicação a ser estabelecida entre a embalagem e o consumidor. No geral, a aparência da embalagem é o elemento mais importante, pois vem a ser o veículo através do qual é estabelecida a estratégia de comunicação entre produtor/ produto/ consumidor.

A aparência da embalagem está estreitamente relacionada com a marca do produto (extensão de marca e/ou com a elaboração de um produto novo). O "nome do produto" é um dos elementos mais importantes no momento em que é efetuado o desenho gráfico da embalagem. Ele está relacionado com a estratégia de comunicação do cereal. O nome em si e a tipografia usada estão muito interligados e representam o binômio produto/ embalagem, ou seja, a identificação do cereal.

A aparência da embalagem é definida em função da marca e da estratégia de comunicação, visando a atingir, primordialmente, o público-alvo (infantil, adulto) de um produto em questão. Além disso, a aparência da embalagem envolve benefícios funcionais e próprios do produto. Por exemplo, a embalagem precisa passar ao consumidor a idéia/ imagem de que o cereal é um 
produto crocante. Os itens cor, desenho/ objetos, fotografias que representam o cereal, personagens de desenho animado constituem o elemento "aparência".

- Concorrência: tipicamente, antes do desenho começar a ser feito, procura-se identificar os concorrentes específicos do novo produto que está sendo desenvolvido. Nessa análise, são identificados os elementos cor e aspecto arquitetônico nas embalagens dos concorrentes. $\mathrm{O}$ desenho da nova embalagem começa após revisão e entendimento de todos os aspectos constituintes da mesma. Essa etapa do processo de desenvolvimento da embalagem é executada com muita profundidade pelos profissionais do Departamento de Marketing.

- Legislação: os Departamentos Legal e de Nutrição da empresa são envolvidos no processo de desenvolvimento da embalagem quando é colocada uma "chamada" ("claim/ splash") relacionada aos aspectos nutricionais do produto. As "chamadas" são informações adicionais, ou seja, não irão afetar o conceito, a imagem do produto.

- Tamanho/ Consumidor: há 3 anos, a empresa utilizava 18 tamanhos diferentes de embalagens para cereais. Fez um estudo e hoje existem 6 tamanhos considerados padrão de embalagens. Para tal, analisou as embalagens empregadas pelos concorrentes, bem como considerou as opiniões dos consumidores. Este último, analisa o aspecto financeiro da compra, isto é, o custo/ benefício da mesma. Compara os elementos peso líquido, tamanho da embalagem e preço do produto em sua tomada de decisão.

Departamento de Engenharia de Embalagem é quem define o tamanho da embalagem, o tipo de máquinas e de logística apropriados ao novo produto (sua densidade) que estiver sendo produzido. Por exemplo, um produto leve como o "Corn Flakes" pode ser colocado em uma embalagem maior, sem que com isso haja um acréscimo significativo no preço final do cereal. Cereais da categoria Muesli e Granola são mais densos. O uso de embalagens maiores irá encarecer sensivelmente o produto.

As embalagens individuais foram desenvolvidas para atender ao aspecto de conveniência do consumidor. É muito prática para ser manuseada por adultos e crianças e utilizada, especialmente, em ocasiões de viagens, "camping", entre outras. É uma forma bem cara de se comprar cereal. Entretanto, existem consumidores que preferem essa praticidade. Dentre os segmentos existentes para esse tipo de embalagem, destaca-se o idoso. Na sua opinião, ao comprar embalagens individuais (unidade de consumo), estará sempre consumindo um produto fresco e crocante.

Além disso, nos Estados Unidos existem cidades em que o clima é muito úmido (por exemplo, Flórida). Decorrente dessa umidade, existem muitos insetos. A embalagem individual não requer cuidados específicos para garantir a preservação das características organolépticas do cereal. Resumindo, seu tamanho é definido em função das necessidades do consumidor e do preço que será praticado no mercado consumidor.

Dessa forma, pode-se dizer que o tamanho da embalagem está relacionado com o aspecto de lucratividade para a empresa, ou seja, retorno resultante do volume de vendas em função de sua aceitabilidade por parte do consumidor.

- Armazenagem e Estocagem: alguns varejistas vêm pegar o cereal no armazém da própria fábrica. Nesse caso, o produto fica armazenado nos depósitos dos varejistas e depois é encaminhado para as lojas. Uma outra situação, são os centros distribuidores contratados pela empresa. Em geral, os armazéns possuem temperatura ambiente, pois o cereal não requer 
refrigeração para sua conservação. As caixas contendo o produto são acondicionadas em pacotes de papelão.

A tecnologia de estocagem é moderna e preserva a embalagem intacta, sem ser danificada. Normalmente, a embalagem de cereal é feita de papelão reciclado. $\mathrm{Na}$ elaboração das embalagens maiores utiliza-se um papelão de gramatura mais espessa. Porém, o desenho gráfico da embalagem e o substrato empregado (tinta, variação de cores, entre outros) na etapa de impressão são considerados padrão para gramaturas diferentes de papelão.

Concluindo, essa fase de armazenagem e estocagem não exerce influência no desenho gráfico da embalagem de cereais.

\section{Passo 2. Recomendações/ Alternativas e Avaliação}

$\mathrm{O}$ início do processo ocorre no Departamento de Marketing, que define o "briefing" a ser apresentado, inicialmente, a várias Agências de Pormoções/ Publicidade com renomada experiência nesse mercado de trabalho. Num primeiro momento, o objetivo de trabalhar com várias Agências visa a identificação daquela que apresente os pontos fortes necessários para a realização desse tipo trabalho, ou seja, elaboração de um esboço do desenho gráfico para embalagens de cereais matinais. Assim, cada uma das Agências, previamente, selecionadas apresentará um esboço do desenho gráfico da embalagem a ser, posteriormente, desenvolvida, bem como uma proposta de custo do projeto em questão. Neste elo da cadeia, a empresa conta com a Assessoria Externa de um profissional ligado a uma Agência de Promoções/ Publicidade.

Desse trabalho conjunto, são obtidas várias versões de desenhos da embalagem. O Departamento de Marketing e os gerenciadores do processo participam dessa etapa, para ajudar a definir que versão de desenho gráfico da embalagem será desenvolvida, bem como qual Agência integrará o grupo de profissionais responsáveis pela elaboração da embalagem final. Essa análise abrange, também, o custo/ beneficio das propostas apresentadas, ou seja, o "good deal for the money" - um bom negócio resultante do montante aplicado.

Os profissionais vinculados ao Departamento de Engenharia de Embalagem, muito ocasionalmente, estão envolvidos no processo. Esse grupo ajuda a definir o material apropriado a ser empregado no desenvolvimento de uma embalagem que fuja aos critérios considerados padrão, ou seja, que ainda não faça parte do portifólio da empresa. Obtendo-se o desenho final da embalagem, esse vai para a etapa de impressão.

\section{Passo 3. Pesquisa; Avaliação e Produção}

A partir da aprovação de uma proposta de custo pela empresa produtora de cereais matinais, dá-se o início da fase de desenvolvimento da embalagem. A Agência de Promoções/ Publicidade realiza uma pesquisa nos supermercados com as embalagens dos concorrentes da marca Kellogg e avalia a gama/ variação de cores usada nessas embalagens, bem como qualquer outro elemento relevante para uma das diversas categorias de cereal matinal produzidas e comercializadas pelo mercado norte-americano. 
Como resultado dessa pesquisa, são elaborados de 8 a 10 (ou mais) tipos de desenhos gráficos de embalagens. Isso traz uma idéia mais ampla de como visualizar os conceitos - "concepts" da embalagem em desenvolvimento. Dessas opções, são selecionados de 6 a 8 modelos, pois a empresa acredita que em um desses modelos estará aquele que conterá os conceitos - "concepts" que podem representar a estratégia de comunicação da marca do produto - cereal.

Para tal, são desenvolvidas pesquisas qualitativas - "perception research" pelas Agências de Promoções e Publicidade. Não há envolvimento direto da empresa. É muito usada a modalidade de discussão em grupos para levantar o entendimento do consumidor acerca da embalagem de cereais. $O$ objetivo dessas pesquisas vem a ser: testar uma embalagem, no sentido de verificar se o conteúdo informativo impresso na embalagem está passando a mensagem que o público-alvo espera, deseja. As informações levantadas serão, posteriormente, adequadamente empregadas pela empresa produtora de cereais.

Durante a realização das discussões em grupo, a empresa procura passar ao consumidor a idéia central, isto é, alguns conceitos e atributos do produto via embalagem. O parecer/ "feedback" do consumidor quanto aos conceitos apresentados aponta que aspectos estratégicos (personagens de desenhos animados, símbolos e figuras) colocados na embalagem trarão resultados satisfatórios. A partir desse retorno do consumidor, é feito um "refinamento" do desenho gráfico das embalagens analisadas e, consequentemente, é selecionada aquela considerada "ideal", ou seja, a que efetivamente será desenvolvida.

Essa escolha é levada à apreciação de uma Diretoria denominada "Senior Management". A seguir, é desenvolvido um teste quantitativo com centenas de consumidores, que serão expostos ao conceito da embalagem em fase de desenvolvimento.

Nesse teste quantitativo - "simulação de prateleira", a embalagem que está sendo analisada é colocada ao lado das dos concorrentes nas prateleiras de alguns supermercados. São avaliados os seguintes elementos:

* aqueles que mais chamam a atenção dos consumidores (por exemplo, logotipo da marca);

- em que ordem esses elementos são identificados (ordem de importância);

- e, principalmente, se o consumidor consegue identificar a "embalagem teste" ao lado das demais embalagens presentes nas prateleiras dos supermercados.

Dando sequência ao estudo, são feitas algumas questões de natureza qualitativa para verificar se o consumidor consegue enxergar os aspectos de comunicação empregados na embalagem-teste. Essas questões procuram enfocar:

* se a mensagem está sendo, claramente, transmitida;

* o tipo de mensagem transmitida ao consumidor acerca do produto via embalagem do cereal matinal; 
- se o consumidor consegue perceber ou não que aquele cereal é uma extensão de linha de outro já existente no mercado (Ex: "Raisin Bran" e "Raisin Bran Crunch");

- se aquele cereal tem conexão com outro já presente no mercado (Ex: "Rice Krispies" e "Cocoa Krispies").

Essa fase de estudo da embalagem em desenvolvimento é denominada "eye tracking", ou seja, visualização do consumidor acerca do produto via embalagem do cereal. Nesse ponto, a empresa pode ter uma idéia mais exata quanto ao desempenho dos modelos de embalagens que estão sendo analisados nos testes. Como resultado, tem-se a redução para 1 a 2 modelos de desenho gráfico de embalagem. Esse refinamento dos modelos é apresentado pela Agência de Promoções/ Publicidade à equipe de profissionais da empresa produtora de cereais matinais, que define, finalmente, qual embalagem será elaborada.

O grupo de profissionais - Pesquisadores sobre o Comportamento do Consumidor - compreendem - Departamento denominado "Consumer Researchers". Eles também auxiliam a empresa a entender as reações e percepções dos consumidores quanto às embalagens de cereais submetidas à apreciação dos participantes das discussões em grupo. Esse Departamento é considerada a chave mais importante do processo de desenvolvimento da embalagem.

\section{Passo 4. Avaliação e Veto}

Quanto à etapa denominada "veto" das embalagens de cereais, existe o Departamento Legal "Advertising Control Committee". Os profissionais que constituem esse comitê interno à empresa são responsáveis pela análise dos aspectos ligados às áreas Legal, de Nutrição, de Atendimento ao Consumidor, bem como pela aprovação de todo o material desenvolvido pelas áreas de Marketing e Vendas. Essa avaliação é um processo padrão da empresa e, normalmente, ocorre antes da embalagem ir para os centros de distribuição e comercialização, ou ainda, quando são feitas modificações (nova promoção, adição de informações nutricionais) na embalagem que se encontra no mercado de consumo.

A composição desse comitê pode variar de acordo com o projeto em desenvolvimento. Ele pode ser composto por integrantes das seguintes áreas: Marketing e Vendas, Embalagem, "Couponing", Promoção, "Kellogg Kitchens", Serviços de Alimentação, entre outros.

\section{Passo 5. Arte Final}

O Departamento de Desenho e Impressão da Embalagem elabora um esboço gráfico. Essa amostra fotográfica descreve o produto inserido no interior da embalagem, ao apresentar ao consumidor todos os elementos/ componentes que constituem o cereal. As áreas de legislação e nutrição da empresa verificam se aquele desenho preenche as recomendações legais e nutricionais para o produto em questão. Se o esboço for aprovado, será feito o desenho final da embalagem. 
Os profissionais vinculados ao Departamento de Desenho e Impressão da Embalagem têm o papel de ajudar a entender o limite de tempo, isto é, o tempo que decorre entre o desenho da embalagem até a sua impressão final. Outra função desse grupo, é justamente a de visualizar o efeito do "desenho gráfico" na impressão final da embalagem. Nesse sentido, os aspectos analisados são: textura, tamanho, cor, foto do cereal, entre outros, no sentido de obter uma visualização considerada ideal da embalagem. $\mathrm{O}$ grupo também desempenha a função de gerenciadores do processo - "project management", isto é, responsável pelo agendamento de reuniões com as Agências de Promoç̃̃es e Publicidade.

\section{Passo 6. "Feedback"}

Neste estágio do processo de elaboração da embalagem de cereais matinais, há a atuação conjunta dos Departamentos de Marketing e de Desenho e Impressão da Embalagem. Esses dois departamentos buscam informações da área de vendas. A opinião desses profissionais reflete o desempenho da embalagem de cereal na prateleira dos supermercados de acordo com o parecer dos consumidores. Como exemplo, destaca-se o caso do cereal "Marshmallow Froot Loops". A embalagem não estava transmitindo adequadamente o conceito, ou seja, era muito similar à caixa do produto denominado "Froot Loops". Com a participação da área de vendas, foram feitos os ajustes necessários. Com isso, obteve-se um retorno muito rápido (apenas 3 semanas) quanto ao desempenho da embalagem desse produto. É bastante significativo esse tempo. Normalmente, levaria em torno de 4 meses o período que abrange desde o levantamento de opinião dos consumidores até o re-desenho e impressão da embalagem.

O Departamento de Marketing é a área que está mais próxima do conceito da marca. Portanto, juntamente com a Diretoria - "Senior management" tem condições de dar a decisão final quanto à embalagem que será realmente produzida.

Concluindo, o processo de planejamento e desenvolvimento das embalagens de cereais descrito anteriormente é o processo considerado formal/ padrão pela empresa. A equipe de profissionais "team work" - da empresa e a Assessoria Externa estão envolvidos em todo o processo. Fica destacado que em todos os estágios ocorre uma Avaliação quanto às ações e definições tomadas a cada etapa da elaboração das embalagens de cereais matinais. Dependendo do ponto de vista em que é visto o processo, ressalta-se:

- Marketing - é responsável pela aparência geral da embalagem, isto é, procura integrar de forma harmônica a categoria do produto (cereais matinais, "cereal bars", "convenience foods") à marca "Kellogg".

- Agência de Promoções e Publicidade - é responsável pela produção artística da embalagem, ou seja, compõe a apresentação das informações nutricionais juntamente com outros elementos integrantes do conteúdo informativo da embalagem. Gera os filmes de impressão que são entregues à empresa.

- Desenho e Impressão da Embalagem - é responsável não apenas pela marca, mas também pela parte estrutural e arquitetônica da embalagem. 
- Vendas - presta uma consultoria interna à empresa, ou seja, acompanha o desempenho da marca no mercado varejista. Observa e capta informações quanto ao preenchimento das necessidades do mercado consumidor, no sentido de verificar se a embalagem está atendendo satisfatoriamente às necessidades do seu público-alvo.

As informações obtidas e que retratam uma idéia global sobre as ações executadas pelas áreas funcionais envolvidas no processo de elaboração das embalagens de cereais matinais, estão apresentadas no Quadro 4.3. 
Quadro 4.3 Estrutura da empresa norte-americana produtora de cereais

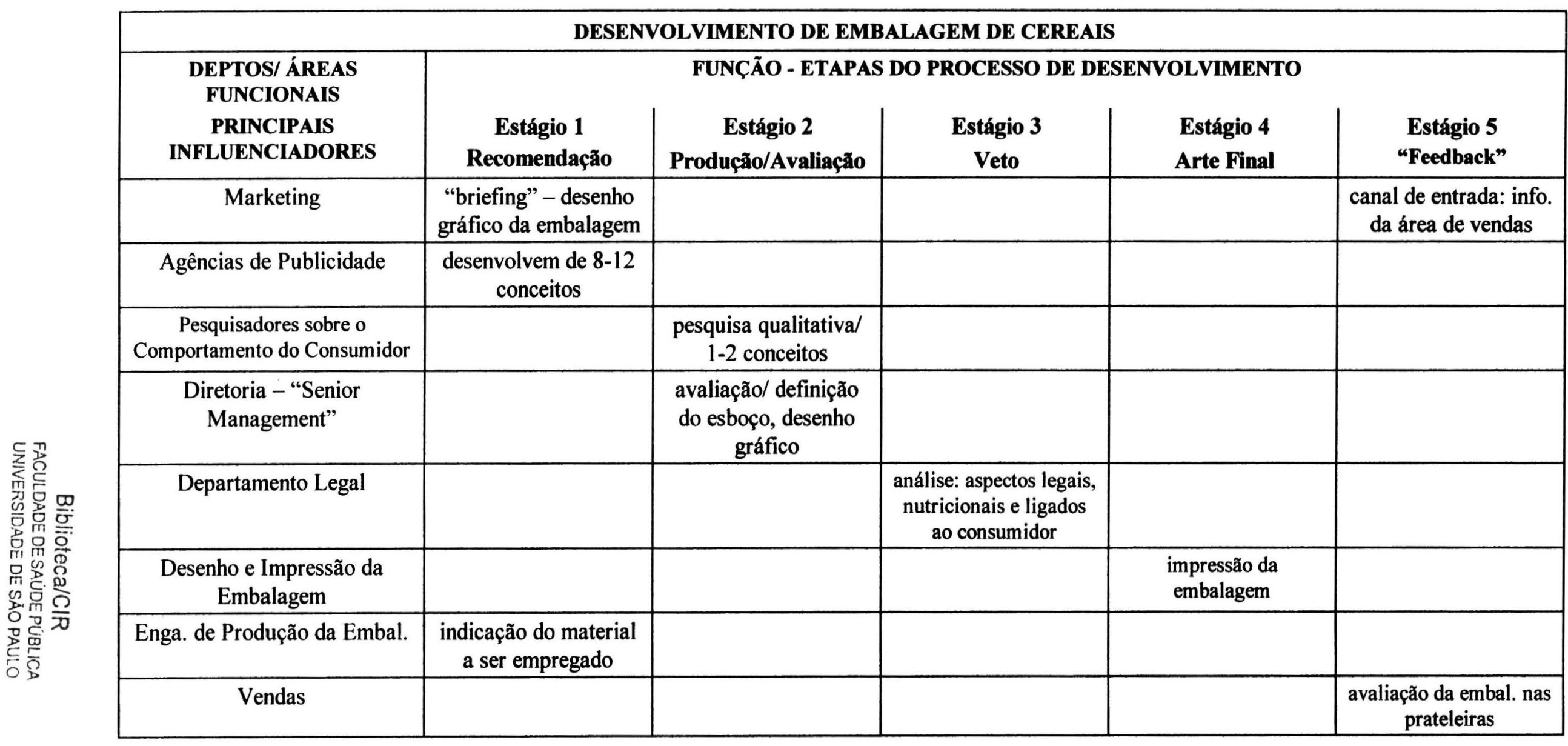

Nota: Quadro elaborado a partir das informações (verbais e escritas) fornecidas pelo agente de produção entrevistado 


\subsubsection{Aspectos Conceituais: entendimento do profissional norte-americano entrevistado}

\section{Papel estratégico das embalagens de cereais matinais}

Segundo o respondente, as lojas representam o primordial negócio da empresa. Elas são o maior gerador de lucro, de retorno financeiro. A imagem da marca - "goodwill" - desde a época de sua criação, pelos irmãos Kellogg, até os dias de hoje, é a "herança da empresa". Através desses aspectos, as embalagens de cereais matinais desempenham um papel marcante no mercado consumidor.

A função/ propósito do binômio produto/ embalagem, vem a ser "a forma como os consumidores nos conhecem. Os consumidores vêm a marca 'Kellogg' como uma commodity, isto é, um produto simples. Hoje, apesar da importante participação dos alimentos de conveniência e cereais matinais que constituem nossa linha de produção e comercialização, a empresa é vista, apenas, como produtora de cereais. Com o tempo, os consumidores irão enxergar a companhia como uma empresa produtora de alimentos de conveniência - "convenience food". No mercado de ações, os investidores, também, focam seu interesse apenas na área de cereais matinais. Essa área é a que proporciona os melhores resultados, por isso, a comunidade de investidores usa o nome 'Kellogg' para elevar a cotação de ações.

\section{Conjunto informativo/ elementos visuais empregado nas embalagens de cereais matinais}

"Nós temos que apresentar adequadamente o produto ao consumidor". A fotografia que apresenta o cereal contido no interior da embalagem é um fator muito importante. Na definição do conteúdo informativo/ elementos visuais, o público-alvo é considerado com muita atenção pela equipe de porfissionais responsável pela elaboração da embalagem.

O nome do produto e o logotipo da marca são dois elementos com forte participação na composição gráfica da embalagem. Eles determinam a aparência da embalagem apresentada ao consumidor. Nesse sentido, o enfoque poderá estar voltado para o aspecto nutricional do cereal, ou ainda, para os beneficios/ atributos do produto.

Atualmente, uma das grandes preocupações da empresa é mostrar ao consumidor os ingredientes que fazem parte da composição do produto. Dependendo da categoria do cereal ("Muesli", "Granola"), a composição gráfica ressalta a presença de ingredientes como frutas secas (amêndoas) e/ou desidratadas (uvas-passas, banana, maçã). Esse procedimento tem como estratégia atrair a atenção do consumidor para a composição do produto. Dessa forma, a idéia a ser transmitida tem que ser apresentada no painel principal da embalagem. 
Ainda, com relação ao conjunto de elementos gráficos que compreende o item ingredientes/ composição do produto, por lei, existem expressões e palavras apropriadas para identificar esses elementos. Dentre elas, o respondente mencionou "peso líquido" do produto, o "nome comum e usual" do cereal, bem como algumas "chamadas"/ "claims ou splashes" tais como "fonte de cálcio", "fonte de fibra". Concluindo, os elementos gráficos "figuras" e/ou "desenhos" não substituem as informações exigidas legalmente (painel nutricional, descrição dos ingredientes) e que se encontram em outras faces da embalagem.

O item "receita" também é um dos aspectos considerados pela empresa no momento de definir o conjunto informativo/ elementos visuais empregado nas embalagens de cereais matinais. Ele está associado aos hábitos/ estilo de vida de consumo do norte-americano. De modo geral, receitas são impressas na época de festas como "Halloween" - Festa das Bruchas, "Thanksgiving" - Dia de Ação de Graças, "Easter" - Páscoa, "Christmas" - Natal e "4 de Julho" - Independência dos EUA. Por exemplo, no Natal, principalmente, o americano dedica um pouco mais do seu tempo para fazer preparações culinárias. Na embalagem do produto "Rice Krispies" colocamos receitas para a elaboração de "treats" - docinhos. O emprego do produto "Corn Flakes" é muito comum na preparação de receitas salgadas (farofas).

No caso da extensão da linha de produtos, como por exemplo "Honey Crunch Corn Flakes" e "Raisin Bran", destaca-se o item "cores". "Estabelecemos uma pequena variação de cores, procurando manter o vínculo existente entre os cereais pertencentes a uma mesma linha de produtos". Essa estratégia permitirá que o consumidor identifique com mais facilidade seu produto nas prateleiras dos supermercados. Dessa forma, considera-se o item "cores" um dos elementos visuais de identificação dos produtos da categoria de cereais.

Para a empresa, o item "prazo de validade" do produto é muito importante. A sua inserção visa a preencher uma exigência legal. Geralmente, a impressão da data referente ao "prazo de validade" é feita na aba superiror da embalagem, mais especificamente, na face reservada para abertura e fechamento da embalagem. Nos Estados Unidos, o consumidor não se preocupa muito em verificar o "prazo de validade" impresso na embalagem. É uma questão de confiança estabelecida entre os mercados varejista e consumidor - "se o produto está na prateleira, está dentro do prazo para consumo".

Sempre que a empresa realiza uma promoção, ocorrem mudanças no desenho gráfico da embalagem. Regularmente, o espaço referente ao lado esquerdo inferior da embalagem é reservado para a inserção/ impressão dos "elementos promocionais". 
Quanto aos itens "forma/ formato" e "tamanho" das embalagens de cereais, a definição desses elementos está baseada nas características do produto em si, no seu transporte, bem como nas exigências da engenharia de produção. Ao considerar esses critérios, a empresa pode oferecer ao consumidor um produto que corresponda às necessidades do mercado consumidor em termos de custo beneficio, ou seja, volume/ quantidade versus preço. A determinação dos elementos “forma/ formato" e "tamanho" deve estar integrada ao desenho gráfico da embalagem. O conjunto forma/ formato/ tamanho/ aparência irá comunicar ao consumidor o produto contido no interior da embalagem.

\section{Conjunto informativo/ elementos visuais: idéias comunicadas ao consumidor}

"O painel principal da embalagem é o mais importante". A face frontal da embalagem é a área visual que chama a atenção do consumidor e que acaba exercendo influência sobre ele na tomada de decisão, no momento de seleção e compra do produto.

Através da composição gráfica da embalagem, a empresa consegue transmitir ao consumidor conceito e beneficios do produto, variedade de sabores, entre outros, que permitem ao usuário, por exemplo, estabelecer uma comparação entre os cereais integrantes de uma dada extensão de linha de produtos.

O espaço existente na embalagem para a impressão de informações mais detalhadas sobre o cereal matinal é bem limitado, reduzido. Portanto, são utilizadas as campanhas publicitárias para a veiculação de informações mais complexas sobre o produto. $O$ conteúdo informativo contido nas embalagens não mantém uma proximidade muito grande com a mensagem comunicada pela mídia (TV, revistas, rádio). O conteúdo informativo/ elementos visuais inserido na embalagem é o fator identificação, ou seja, é por seu intermédio que o consumidor identifica seu "cereal favorito".

De modo geral, os elementos visuais como promoções, jogos, personagens, entre outros, impressos na embalagem de cereias estão mais voltados para o público infantil.

\section{Principais aspectos na escolha dos elementos visuais inseridos na embalagem}

A definição pelos elementos visuais das embalagens de cereais matinais está relacionada com a marca, bem como com o público-alvo a ser atingido. Através desses aspectos o grupo de profissionais da área de Marketing procura detectar que elementos irão atender às necessidades e expectativas do segmento identificado para um determinado tipo de cereal.

Os aspectos legais são elementos incorporados à embalagem pela sua própria exigência legal. A inserção da composição nutricional do cereal, por exemplo, não é destacada no painel principal da embalagem. Não está, portanto, baseada na mesma estratégia de marketing atribuida aos elementos gráficos (foto do cereal, personagens) impressos na face frontal da embalagem. 
No que diz respeito ao item exigência do mercado consumidor, a empresa coloca à disposição do consumidor um "web site". Por seu intermédio é levantada a opinião dos usuários de cereais matinais. Através da Internet, o consumidor gosta de estar em contato direto com a marca/ produtor do cereal que consome. É a oportunidade, por exemplo, de ter acesso à informação sobre o destino final da embalagem (reciclagem), pois são consumidores preocupados com a preservação do meio-ambiente. Outro ponto de interesse desses consumidores diz respeito aos requerimentos nutricionais (ferro, cálcio) definidos, legalmente, pelo órgão governamental denominado "Food and Drug Administration - FDA".

O conjunto de informações à disposição no "web site" é definido em função das próprias exigências/ necessidades do consumidor. Forma-se, dessa forma, o processo de comunicação aberto entre produtor/ consumidor.

\section{Composição de grupos informações $\&$ seus correspondentes elementos}

- Imagem do produtor/ fabricante: logotipo/marca, serviço de atendimento ao consumidor

A empresa emprega o logotipo (marca "Kellogg") de diferentes maneiras, dependendo do tipo do cereal matinal. Por exemplo, o "Corn Flakes" (Sucrilhos, no Brasil) é o cereal mais simples - "generic" da empresa. Portanto, a comunicação da marca torna-se um fator muito importante. Por seu intermédio, a empresa transmite o conceito de valor, bom sabor, bem como de alta qualidade do referido produto. Consequentemente, pode-se dizer que "a marca por si só vende o produto".

A informação referente ao serviço de atendimento ao consumidor proporciona a possibilidade do consumidor adquirir mais informações (nutricionais, promoções) sobre o produto. É também uma forma do consumidor emitir sua opinião sobre o produto/ empresa ("feedback" do consumidor).

- Apresentação do produto/ comunicação visual do produto: nome do cereal - tipografia, fotografias, figuras, símbolos

nome do cereal, também denominado pela respondente - a "marca em si" - representa uma outra área de comunicação da embalagem. O nome do cereal reforça, enfatiza, chama a atenção do consumidor para um produto familiar. Esse elemento enfatiza e comunica os valores e beneficios funcionais do cereal, como por exemplo, consistência crocante - "crunch", textura de crespinhos - "krispies", o formato de flocos - "flakes", ou ainda, a idéia de um produto glaceado, coberto com açúcar - "froasted flakes". O nome do cereal precisa descrever claramente como é o produto que está inserido no interior da embalagem. Por exemplo, a empresa produziu um produto chamado "Temptation" (já retirado do mercado). Segundo o respondente, o cereal continha ingredientes "tentadores" como nozes/ "pecans" caramelizadas (pralinê) e granola coberta com iogurte. $\mathrm{O}$ nome do produto e a tipografia empregada na impressão desse cereal visavam a mostrar a essência da "marca em si". Os profissionais vinculados às áreas de marketing e propaganda, ao estruturar a estratégia de comunicação do produto, não conseguiram obter uma "imagem impressionista", ou seja, empregar fotos reais acerca do produto inserido no interior da embalagem. O retorno de vendas mostrou que essa estratégia de comunicação não era adequada, pois os consumidores não conseguiam visualizar, imaginar como realmente o produto viesse a ser, antes de abrir a embalagem. $O$ produto não era comprado, pois os usuários não queriam ser surpreendidos. Mesmo mudando a estratégia de comunicação (impressão de fotos reais do cereal) empregada na embalagem do produto, o 
retorno não foi favorável. O produto faliu e, portanto, retirado das prateleiras dos supermercados. $O$ nome usual do produto além de ser uma exigência legal, é uma das importantes peças de comunicação entre o produtor e o consumidor.

Concluindo, os elementos gráficos (logotipo, personagens de desenhos animados) impressos na embalagem de cereais chamam mais a atenção do consumidor para o produto, pois é através deles que a empresa comunica o conceito do produto.

- Comunicação nutricional: tabela nutricional do cereal, composição do produto/ ingredientes, "chamadas" - "claims/ splashes", logotipo.

A comunicação acerca da informação nutricional do produto pode variar de acordo com o tipo de cereal. A forma empregada no produto "Corn Flakes" é considerada padrão. Também há formas de comunicação baseadas nas atividades do marketing. Como por exemplo, a chamada "K-sentials for energy", "K-sentials for growth", and "K-sentials basics" está mais voltada para o público infantil. No primeiro, a empresa procura enfatizar a presença de vitaminas do grupo B; no segundo, fica ressaltada a incorporação de minerais como zinco, ferro e cálcio. Quanto à expressão "K-sentials basics", está direcionada para "toddlers", ou seja, crianças que estão aprendendo a andar. No caso de cereais, como exemplo "Froasted Flakes", que estampam o logotipo da "American Heart Association- AHA", a empresa procura enfatizar o consumo de uma dieta balanceada e com baixo teor de gordura e colesterol. $\mathrm{O}$ emprego do logotipo nesses produtos busca enfatizar os aspectos nutricionais relevantes para o consumidor, dependendo da sua faixa etária, das suas atividades, entre outros. Praticamente, as informações nutricionais impressas nas embalagens de cereais são pontos essenciais, através dos quais dá-se a venda do produto. Por intermédio dessas informações e da lista de ingredientes/ composição do produto que compre o cereal, o consumidor tem a oportunidade de aprender, adquirir e/ou ampliar seu conhecimento sobre os aspectos nutricionais do produto.

Não é por intermédio das "chamadas" que destacam o baixo teor de gordura e/ou açúcar do cereal, que a empresa procura comunicar o conteúdo existente no interior da embalagem. Essa informação é comunicada ao consumidor de uma maneira simples. Por exemplo, o cereal "Corn Flakes" é "livre de gordura". Essa informação é do conhecimento do consumidor que conhece "o seu produto", que está familiarizado com esse tipo de cereal.

- Comunicação promocional: elementos promocionais em si, receitas, preço/ cupons, peso líquido.

Há, também, na embalagem, a área destinada à inserção de informações promocionais. Como exemplo de uma oferta promocional pode ser mencionada a inclusão de uma amostra grátis de cereal à embalagem de outro produto. Esses elementos promocionais são impressos no painel principal da embalagem. Muitas vezes, o consumidor é atraído por esse tipo de informação. Outro tipo de informação promocional vem a ser as receitas, que mostram usos alternativos do produto, isto é, o emprego do cereal em preparações culinárias ("treats" - docinhos). Os itens preço e cupons também são considerados elementos promocionais, incentivos para que o consumidor venha a adquirir o cereal. É uma forma extra de promover o produto.

Antigamente, a empresa colocava brinquedos no interior das embalagens de cereais. Hoje, essa estratégia promocional do produto tornou-se inviável para a empresa. "O retorno obtido com a venda do cereal não chegava a compensar os custos de produção e promoção do cereal". 
A inserção do item peso líquido é uma exigência legal. Além disso, sua presença no painel principal da embalagem permite que o consumidor compare o valor/ preço do cereal em relação ao seu rendimento/ volume, entre às marcas ofertadas pelo mercado.

- Informações legais (exigência legal acerca do binômio produto/ embalagem e sobre o fabricante): peso líquido, prazo de validade, código de barras (preço do produto), código da embalagem ("cartoon code"), inserção da marca ("trademark"), símbolos - reciclagem, logotipo do sindicato ("union logo").

\section{Relevância dos Atributos}

A ordem de importância/ relevância atribuída pela empresa a cada um dos elementos constituintes das embalagens de cereais matinais, vem a ser:

- marca "Kellogg": a empresa estabelece uma estreita relação entre a marca e os aspectos nutricionais do cereal. Preocupa-se em transmitir ao consumidor, por intermédio dessa mensagem visual, que existe uma consciência voltada para o aspecto nutricional do produto.

- nome do produto: comunica ao consumidor a "personalidade da marca". É através desse elemento que o consumidor se identifica com seu produto - cereal.

- personagens de desenho animado: dependendo do tipo de cereal, esse elemento é visto com significativa relevância pelo consumidor. Por exemplo, o cereal "Froasted Flakes" é um produto voltado, principalmente, para o público infantil. Nesse caso, a embalagem apresenta a figura do personagem "Tony the Tiger". A figura desse tigre está associada à prática de esportes e, assim, a apresentação envolve modalidades de esporte como esquiar, surfar, entre outras. A junção dessas idéias (personagem infantil e prática de esporte) é parte da comunicação da marca e é valorizada pelo público-alvo consumidor. O cereal é visto como um produto que contribui para uma performance melhor, pois proporciona energia e, ao mesmo tempo, "coloca o consumidor em movimento" (prática de uma atividade esportiva).

- informação nutricional: a comunicação acerca da informação nutricional do produto pode variar de acordo com o tipo de cereal. A inserção de "chamadas" para destacar o valor vitamínico e/ou de minerais no cereal é uma estratégia, que busca enfatizar os aspectos nutricionais relevantes para o consumidor, dependendo de sua faixa etária. Outro exemplo, é o caso do logotipo da "American Heart Association - AHA". Esse elemento visual reforça os beneficios e as vantagens advindas de uma alimentação saudável e balanceada em termos de teor de gorduras e açucares. $\mathrm{Na}$ seleção dos elementos gráficos, a empresa considera as "chamadas nutricionais" como elementos secundários em termos de atrair a atenção do consumidor para o painel principal (frontal) da embalagem.

- informação promocional: há também na embalagem, a área destinada para a inserção de informações promocionais. Ou seja, ofertas especiais que o consumidor pode ganhar ao adquirir um determinado tipo de cereal. Como exemplo de ofertas promocionais, cabe destacar "amostra grátis do produto", "embalagem gratuita de marshmallow". Esses elementos promocionais são impressos no painel principal da embalagem. Muitas vezes, o consumidor é atraido por esse tipo de informação. Outro tipo de informação promocional vem a ser as receitas, que mostram usos alternativos do produto, isto é, o emprego do cereal em preparações culinárias ("treats"- docinhos).

Os itens "preço/ cupons" também são considerados elementos promocionais, incentivos para que o consumidor venha a adquirir o cereal. É uma forma extra de promover o produto. 


\section{Comunicação da Embalagem}

Quando uma nova marca de cereal está em desenvolvimento, são considerados os elementos demográficos, sócio-econômicos, tendências, características e costumes apresentados pelo públicoalvo para o produto em questão. Com o levantamento dessas informações, "conseguimos segmentar o mercado, identificar nichos de mercado que precisem ser melhor explorados/ trabalhados". Portanto, o binômio produto/ embalagem é desenvolvido com base nas características desse grupo de consumidores potenciais de cereal. A fase de teste do novo produto permite que a empresa mantenha contato com esses consumidores, bem como ajuda a delimitar o alvo a ser atingido pela empresa.

Por ocasião da entrevista, a empresa tinha acabado de desenvolver e lançar no mercado um novo tipo de cereal - "Country Inn Specialities". É um produto de natureza "premium", desenvolvido a partir de receitas e de ingredientes especiais. A idéia partiu de uma atual tendência, no comportamento do consumidor norte-americano, em valorizar o "gourmet" que aprecia consumir alimentos comercializados em pequenas porções. São produtos com preço diferenciado, ou seja, voltados para um segmento de mercado disposto a pagar mais por um produto considerado "premium".

Para tal, basearam-se na existência de outras categorias de produtos alimentícios que empregam a expressão "classics" no nome do produto. Os consumidores desse segmento valorizam o requinte (ingredientes especiais - grãos, frutas secas), a produção artesanal do item, pequenas porções de consumo, bem como embalagens diferenciadas. A empresa identificou, portanto, uma nova oportunidade a ser explorada (nicho de mercado) na linha de cereais. O "Country Inn Specialities" está voltado para um segmento, também, especial de consumidores. São mulheres entre 35 a 45 anos de idade, que trabalham e querem "ter seu próprio tempo para relaxar enquanto apreciam/ consomem o cereal".

Para atender à idéia de um produto considerado da linha "classic", bem como ao perfil desse segmento de mercado, a empresa decidiu que o "Country Inn Specialities" não apresentaria a marca "Kellogg". O cereal seria produzido por uma empresa de porte pequeno e especializada na elaboração de receitas especiais. Consequentemente, não seriam empregadas as tradicionais caixas cartonadas como embalagem final do produto. Seriam empregados pequenos invólucros de papel plastificado com requintada composição gráfica. A união desses elementos transmitiria a idéia de produto artesanalmente elaborado.

Concluindo, antes da tomada de decisão pelo desenvolvimento do "Country Inn Specialities", a empresa realizou uma pesquisa através da qual identificou a oportunidade de atingir um nicho de mercado para produtos de linha "premium" ("classics"), já existentes em outras categorias de produtos alimentícios. A existência desse perfil de consumidor cria a necessidade de alcançar esse segmento de mercado por intermédio do desenvolvimento de um cereal diferenciado. Os aspectos demográficos explicitados anteriormente foram identificados e entendidos como sendo o alvo a ser melhor trabalhado (explorado) com a entrada do "Country Inn Specialities". 
Um outro exemplo a ser mencionado abrange os seguintes cereais:

* "Raisin Bran": foi desenvolvido para consumidores com 45 anos ou mais. O público-alvo desse cereal valoriza o "nome do produto" ("Raisin Bran"). São considerados consumidores fiéis à essa marca (o cereal vem sendo consumido há muito tempo) e que não dão tanta importância ao fato de o cereal murchar ou não ("soggy") quando adicionado ao leite.

- "Raisin Bran Crunch": é voltado para consumidores mais jovens ((homens e mulheres entre 25 e 45 anos), que estão preocupados com sua saúde, querem um produto mais nutritivo como a Granola, que seja mais crocante, bem como proporcione maior poder de saciedade. O cereal da categoria "Raisin Bran" já confere esse poder de saciedade. Também está associada ao "Raisin Bran Crunch" a idéia de o produto conferir energia, que pode ser despendida em exercício fisico ("bike") para melhorar a disposição - performance - do consumidor.

Falando em cereais de um modo geral, o público-alvo é definido antes de ser desenvolvida a embalagem. Para cada produto, tem-se o cuidado de desenvolver a "imagem ideal" para aquele segmento de consumidores (adulto, infantil). A composição gráfica da embalagem está mais voltada para o público feminino, pois, ainda, é atribuída à mulher a responsabilidade pelas compras da familia.

\section{Critérios de Escolha de Cereais Matinais}

"Nos Estados Unidos, todos consomem cereal. Normalmente, a familia norte-americana compra, no minimo, duas caixas de cereal matinal por mês". Com isso, o gosto de cada integrante da familia acaba sendo contemplado. A cada compra, as famílias norte-americanas procuram variar o tipo de cereal em relação à compra anterior. Outro fator que determina a escolha do tipo de cereal é a "chamada promocional", isto é os cupons. Com os cupons, na próxima compra, o consumidor norte-americano poderá adquirir o mesmo cereal por um preço menor. "A presença de crianças no momento da compra, também, acaba influenciando o consumidor quanto ao tipo de cereal a ser adquirido".

Segundo o respondente, o cereal "é parte funcional da vida do americano". O produto é consumido tanto no café da manhã, no almoço, no jantar, ou ainda, como um "snack" - lanche. É um alimento que está vinculado à dieta norte-americana. Cada vez mais, o norte-americano está sem tempo para preparar um café da manhã considerado convencional (ovos com bacon, panqueca, entre outros). O cereal se torna uma conveniente opção, pela sua praticidade no preparo e consumo (basta, apenas, acrescentar leite), bem como pelo seu valor nutritivo (reduzido teor de gordura). Por outro lado, há consumidores que não consideram o cereal um produto saudável por conter muito açúcar. Nesse caso, a empresa oferece opções alternativas, em termos de cereais matinais com baixo teor de açúcar e/ou sem açúcar.

Quanto à parte gráfica da embalagem, o mercado oferece ao consumidor uma diversificada gama de opções. "O aspecto visual da embalagem precisa causar um impacto positivo $e$, consequentemente, destacar o produto nas prateleiras dos supermercados". Os elementos que atraem a atenção do consumidor para o produto são: logotipo da marca, nome do cereal, 
personagens de desenhos animados, a própria foto do cereal e a cor do fundo da embalagem. Este último elemento, auxilia o consumidor na identificação do seu produto. Por exemplo, no cereal "Froasted Flakes" - Sucrilhos (no Brasil), a cor azul já é familiar para o consumidor. Ao ver essa cor nas prateleiras dos supermercados, o consumidor cria uma identificação entre o tipo de cereal $e$ a cor da embalagem. Como resultado, sente-se atraído para o produto.

Quanto às informações nutricionais, o entrevistado considera que esse conjunto de informações não atrai tanto a atenção do consumidor no momento em que ele efetua a compra do produto. Portanto, os elementos que descrevem o conteúdo nutricional do produto não recebem o mesmo destaque que os demais elementos gráficos impressos na embalagem.

No geral, a empresa vem incorporando mais vitaminas na composição dos cereais. O consumidor é atraído por esse tipo de chamada - "claims ou splashes". A tipografia empregada na escrita desse elemento visual busca levar o consumidor a dispensar mais tempo para analisar o conteúdo daquele produto.

\section{Hábito de Compra e Consumo do Consumidor}

A empresa tem uma diversificada variedade de produtos - cereais. Além disso, quando é lançado um produto novo, procura-se introduzir aquele que atenda ao gosto/ paladar do consumidor, bem como desperte seu interesse em prová-lo. "O consumidor americano cresceu e vem crescendo com os nossos produtos. Essa situação é uma questão de herança, ou seja, a proximidade do consumidor com o cereal". Portanto, os consumidores já estão familiarizados com os produtos da marca "Kellogg", considerando-os:

- cereais matianis de que gostam e de alta qualidade (confiam na marca);

- para atender às suas necessidades nutricionais e/ou de paladar. Têm a opção de escolher um produto mais nutritivo, ou com conteúdo mais elevado de fibra, ou ainda, um que apresente sabor mais adocicado.

O tipo de produto exerce maior influência na tomada de decisão do consumidor do que o estilo de vida que ele leva. Por exemplo, se o consumidor considerar o cereal "Raisin Bran" um item alimentício que proporciona um poder de saciedade maior do que o cereal "Rice Krispies", essa diferença identificada pelo usuário irá definir quando e como consumir cada um desses dois tipos de cereal matinal (café da manhã, almoço, lanche, jantar, refeição mais pesada ou mais leve).

\section{Influência do SAC - "Consumer Affairs"- na Embalagem}

O termo "customer" na empresa está relacionado com a figura do varejista. Dessa forma, o Departamento de Atendimento ao Cliente facilita os pedidos emitidos pelos varejistas e lida com os problemas e necessidades decorrentes do varejo e, consequentemente, apresentados pelo varejista. 
O termo "consumer" diz respeito ao consumidor final, aquele que compra os "nossos produtos" nas prateleiras dos supermercados.

O Departamento de Atendimento ao Consumidor ("Consumer Affairs") recebe ligações de consumidores que querem comunicar "suas preocupações". Por intermédio dessas chamadas, "o departamento capta a opinião do usuário acerca do nosso produto, bem como registra sugestões e/ou reclamações". As manisfestações referentes às reclamações podem envolver situações que estejam relacionadas desde a conservação do produto até o seu emprego em preparações culinárias.

O Departamento de Atendimento ao Consumidor ("Consumer Affairs"), de quatro em quatro meses publica as manifestações registradas sobre a embalagem, o desenvolvimento de promoções, bem como sobre o cereal em si. Essa publicação é distribuída para todos os departamentos da empresa. $O$ grupo de profissionais envolvido no processo de desenvolvimento da embalagem de cereais procura ter em mente essas manifestações, as quais serão consideradas em futuros projetos. "Nos dias de hoje, quando o consumidor nos contata, não apenas para nos cumprimentar, mas para dar uma excelente idéia sobre alterações na embalagem e/ou propaganda, em virtude de razões legais nós não podemos pô-las em prática. Incorporá-las representa potencialmente um risco legal devido ao pagamento de patentes e/ou direitos autorais. Podemos empregá-las de forma mais abrangente, não considerando todas as suas particularidades. Efetivamente, fazemos o seu registro e procuramos incorporá-las na medida do possivel".

Durante o estágio em que a embalagem está em fase de aprovação a empresa recebe os "inputs" do Departamento de Atendimento ao Consumidor. A contribuição do consumidor é incorporada à embalagem antes que esta seja lançada ao mercado. Através desse procedimento, a empresa encontra uma forma de dar seu retorno diário ao consumidor. Isso evita descontentamentos (reclamações) futuros.

\section{Embalagem Ideal de Cereais Matinais}

- a curto prazo: modificações na parte gráfica da embalagem são efetuadas a curto prazo, período que varia de 3 a 6 meses. Essas alterações estão baseadas na opinião do consumidor (sugestões, reclamações). O emprego de uma linguagem distorcida ao comunicar, por exemplo, o conceito do produto poderá ser alterada num espaço de tempo reduzido.

- embalagem ideal: na opinião do entrevistado, "a empresa já alcançou a embalagem considerada ideal, ou seja, aquela que estabelece uma harmônica comunicação com o consumidor".

- a médio prazo: situações que requeiram alterações na parte estrutural da embalagem, demandam mais tempo para sua implementação. Por exemplo, se o consumidor manifestar dificuldade em abrir o lacre da embalagem plástica contida no interior da caixa do cereal, esse problema levaria a empresa a rever o tipo de fecho desse invólucro. Modificações relacionadas à qualidade da maquinaria são consideradas de larga infra-estrutura e enquadram-se na parte estrutural da embalagem. Portanto, requerem um tempo mais longo para que sejam efetuadas. Por exemplo, uma nova forma de impressão prática, fácil e que possibilitasse o emprego de 
maior variação de cores viria a oferecer um efeito visual mais claro/ consistente. O conjunto desses fatores geraria uma embalagem com aparência visual mais atraente para o consumidor. $O$ desenvolvimento de um mecanismo com qualidade e menos oneroso na elaboração (desenho) e impressão (conteúdo gráfico) da embalagem trariam beneficios para a empresa. Naturalmente, a redução no custo da produção da embalagem, também, traria ganhos e beneficios para o consumidor.

- embalagem ideal: a embalagem precisa, continuamente, desempenhar o seu papel, ou seja, dar adequado suporte às estratégias da empresa. Assim, ao longo do tempo, a embalagem absorve as estratégias da empresa, as quais são traduzidas e comunicadas via embalagem. Portanto, "profundas mudanças na empresa, levam a mudanças na embalagem".

"Agora, nos Estados Unidos, a categoria de cereais não está crescendo". Em contra partida, o mercado tem oferecido ao consumidor opções alternativas como "bagels" e outros produtos embalados em saco plástico e práticos de serem preparados e consumidos pelo usuário tanto em casa e/ou no ambiente de trabalho.

\subsubsection{Empresa brasileira produtora de cereais matinais}

\subsubsection{Processo de desenvolvimento da embalagem}

Segundo o entrevistado, a aplicação de uma visão sistêmica para o desenvolvimento da embalagem tem seu início a partir da elaboração do "briefing" passado à Agência de Promoções. "No momento em que são definidos os objetivos de marketing, por exemplo, ênfase ao valor nutricional do cereal versus descrição apetitosa do produto, é estabelecido o conceito a ser transmitido ao consumidor. A embalagem é fruto dos objetivos que foram definidos a priori". Esses objetivos constituem o conjunto informativo/ elementos visuais da embalagem. Paralelamente, existem outros fatores (mídia, campanha de lançamento) integrando o funcionamento do sistema.

Basicamente, os profissionais envolvidos no processo de desenvolvimento da embalagem estão vinculados às áreas de Marketing e de Desenvolvimento \& Qualidade. Esta última, é responsável, principalmente, pela definição das medidas técnicas, isto é, quanto a embalagem vai ter de largura, de altura, dobras, entre outras. Por exemplo, a área de Desenvolvimento atua, mais especificamente, quando se trata de um projeto especial - um "display", ou ainda, um invólucro plástico diferente. No caso de uma embalagem comum, ou seja, considerada padrão, a empresa dispõe de alguns tamanhos previamente definidos.

A seguir serão destacados os aspectos básicos identificados no processo de elaboração das embalagens de cereais matinais:

- Maquinaria: exerce grande influência. A empresa utiliza cartuchos com tamanhos padronizados. Hoje, por exemplo, a maquinaria existente exige uma justificativa muito forte para que cartuchos com tamanhos intermediários entre 320 a $500 \mathrm{~g}$ sejam desenvolvidos.

- Logística: influência é pequena em termos de "layout"/ visual da embalagem. Nos últimos anos, em função de um apelo logístico a empresa precisou transformar três produtos - os cereais "Froot Loops", "Choko Krispies" e "Honey Nuto's em bilíngues. A padronização do 
tamanho das embalagens, também, é feita em função do aspecto logística, isto é, da caixa de embarque.

- Tamanho/ Consumidor: são quatro as variações de tamanhos das embalagens de cereais: pequeno: "All Bran", "Muesli" e "Granola"; médio: "Sucrilhos" ("Frosted Flakes" - EUA), "Sucrilhos Chocolate", "Chokos", "Froot Loops", "Choko Krispies"; grande: "Sucrilhos Chocolate"; familia: "Corn Flakes" é, basicamente, o milho prensado. Para tal, a empresa considerou os tamanhos praticados em alguns países da América Latina (influências externas). "Foram feitos pequenos ajustes, imperceptiveis aos olhos do consumidor de cereal". O tamanho da embalagem está relacionado com número de porções para consumo. Um cartucho de tamanho médio, conterá porções para uma semana. A cada semana, o consumidor adquire um produto "fresco e crocante". O volume dos cartuchos varia muito em função do peso liquido (densidade) do cereal. Por exemplo, os cereais "Sucrilhos - com cobertura de açúcar", "Sucrilhos Chocolate" e "Chokos" possuem embalagens do mesmo tamanho. Varia, apenas, o peso líquido de cada um deles em função da densidade dos diferentes produtos. "Pesquisa sobre o comportamento do consumidor não é comum. Pode ocorrer no caso de uma modernização no visual da embalagem, ou ainda, na uniformização da embalagem de uma linha de produtos". Por exemplo, a extensão de linha - "Granola Amêndoas e Canela" passou a apresentar logotipia mais moderna e ao produto original foi inserida a chamada "Tradicional".

- Armazenagem, Estocagem \& “Trade” ou Cliente: estes elementos estão vinculados ao aspecto de logística. A Área de Desenvolvimento \& Qualidade analisa os aspectos pertinentes à resistência e segurança das caixas de embarque, bem como define o número ideal de cartuchos (20 a 24) no seu interior. Este último, viabiliza negociações com os clientes, sem onerar a operação com supermercadistas de pequeno porte.

- Distribuição e Transporte: exerce uma influência técnica. Determina o fator resistência da embalagem durante o seu empilhamento. Nesta fase, o cartucho não pode ser danificado (amassado). Dentro dos cartuchos vêm as embalagens plásticas ("liners") que acondicionam o cereal. Esse invólucro plástico já foi alterado por questð̃es técnicas, tornando-se mais resistente, mais barato e mais transparente. Esses ajustes foram recomendados pelas Áreas de Desenvolvimento \& Qualidade, Marketing, Vendas, bem como pelo mercado consumidor. Esta etapa não está ligada diretamente ao aspecto da arte gráfica da embalagem. Entretanto, acaba exercendo, indiretamente, influência no desempenho do produto durante sua comercialização.

- Aparência: é definida em função da estratégia de comunicação estabelecida, que busca atingir, primordialmente, o público-alvo do produto em questão. A aparência da embalagem envolve beneficios funcionais e próprios do produto. Por exemplo, a embalagem do cereal "All Bran" precisa passar ao consumidor a idéia/ imagem de que o produto possue elevado teor de fibra.

- Concorrência: no geral, "nós fomos os líderes, os pioneiros no mercado de cereais. 90\% das embalagens são originais, os concorrentes acabaram tomando-as como base para a elaboração das dos seus produtos. Hoje, basicamente, o mercado de cereais matinais é composto pelos nossos produtos. A atual embalagem do produto 'Chokos'é uma exceção. $O$ desenvolvimento do projeto levou em consideração o cereal da marca concorrente - 'Nescau'. Mantivemos o nome original do produto - 'Chokos' e desenvolvemos um novo cereal pertencente ao mesmo nicho de mercado em relação ao do concorrente. $A$ aparência visual da embalagem (cores, peso líquido, formato), composição (sabor), características da categorial 
identidade visual do produto, permitiu que o cereal tivesse preço mais competitivo em relação ao do concorrente. Foi uma ousadia da empresa. O público-alvo para ambos os produtos é o mesmo-adolescentes. $O$ 'Chokos' tem uma identidade muito forte (identidade visual forte na gôndola) e um posicionamento muito especifico. Buscou-se um posicionamento totalmente inovador, para o futuro e embrionário uso da Internet". O nome do cereal corresponde ao endereço eletrônico/ site do produto na Internet. Em termos de beneficios, são dois produtos completamente distintos.

- Legislação: exerce influência em termos da definição de algumas informações impressas na embalagem, como por exemplo: peso líquido do cereal, dados sobre o fabricante, número de registro do produto, CNPJ - Cadastro Nacional de Pessoa Jurídica (veio para substituir a sigla $\mathrm{CGC}$ ). $\mathrm{Na}$ opinião do respondente, "a influência desse elemento em termos visuais da embalagem e, consequentemente, para o consumidor, é muito pequena".

\section{Passo 1. Principais Influenciadores}

De acordo com o respondente, o início do processo de planejamento e desenvolvimento da embalagem vem da área de Marketing. $O$ desenvolvimento do produto e da embalagem ocorre paralelamente. É feito pela Área de Desenvolvimento \& Qualidade.

Praticamente, todo o processo é controlado pelo Gerente de Produto. "Ele é o articulador de todas as negociações existentes nas fases de elaboração da embalagem de cereais". O entrevistado utilizou, como exemplo prático, o desenvolvimento da embalagem para um dos mais recentes lançamentos da empresa - o cereal "Sucrilhos Banana".

A idéia partiu da Área de Marketing, a qual fez toda a coordenação do processo de desenvolvimento da embalagem. O papel da Área de Desenvolvimento \& Qualidade foi garantir o cumprimento das especificações técnicas e dos aspectos legais para a embalagem de cereais, tais como: tamanho, informações nutricionais, exigência legal em termos de qualidade, entre outras. Definido esse procedimento inicial, a Área de Marketing passa um "briefing" sobre o "background"/ origem do produto para a Agência de Promoções. Como a Agência já trabalha com a empresa há muito tempo, não há a necessidade de entrar em detalhes acerca da empresa e de suas atividades. $\mathrm{O}$ "briefing" é voltado especificamente para o novo produto.

\section{Passo 2. Recomendações/ Alternativas \& Avaliação}

A Agência de Promoções entra no processo após o estabelecimento interno dos aspectos técnicos da embalagem pela empresa. Presta, portanto, uma Assessoria Externa no que se refere ao desenvolvimento do desenho gráfico da embalagem e/ou de promoções específicas.

O cereal "Sucrilhos Banana" já existiu no Brasil entre os anos de 1983 a 1989 e foi um produto de muito sucesso nessa época. Por uma decisão estratégica da empresa de se eliminar as extensões de linha, manteve-se apenas o "Sucrilhos" tradicional. Este último, até hoje, "é lider de mercado nessa categoria de cereal". Atualmente, a empresa viu uma oportunidade de estar relançando o cereal "Sucrilhos Banana", com a introdução de uma novidade para a marca, ou seja, a questão do 
sabor tropical da banana. Todas essas informaç̃̃es são passadas para a Agência de Promoções. Em seguida, são apresentados os objetivos específicos para a embalagem do cereal. No caso, a criação de uma embalagem extensão de linha da "familia Sucrilhos" requer uma série de elementos, entre eles: o logotipo da marca. O próximo estágio é trabalhar os principais pontos a serem ressaltados na embalagem do novo produto, tais como: explorar a tropicalidade/ sabor da banana, a originalidade do produto e a modernidade da embalagem. A Agência faz alguns estudos e desenvolve um esboço do desenho gráfico da embalagem para ser analisado em conjunto com a Área de Marketing. Definido/ aprovado o "lay out"/ visual da embalagem, as Áreas de Desenvolvimento \& Qualidade e o Juridico entram no processo e fazem uma verificação técnica, isto é, se o texto impresso não apresenta erros de ortografia, se o tamanho está de acordo com as especificações da empresa, se as informações nutricionais estão corretas, exigência legal em termos de qualidade, entre outras.

\section{Passo 3. Produção/Impressão \& Avaliação}

A empresa aciona um fornecedor - Gráfica ou "Bureau" para imprimir o fotolito da emblalagem. É por intermédio da Área de Compras que esse fornecedor é incorporado ao processo. A gráfica recebe um disquete contendo a arte gráfica da embalagem previamente aprovada. Fornecida a prova de fotolito - cromalim, Marketing faz uma avaliação/ verificação do material impresso pela gráfica.

Agora, tem-se o último estágio de elaboração da embalagem. Uma segunda Gráfica é acionada para confeccionar, ou melhor, imprimir, propriamente dito, a embalagem de cereal. Esse fornecedor presta serviço há muito tempo para a empresa. Sabe, portanto, todos os padrões de impressão e de cores (algumas são especiais) requeridos. Nessa etapa, é feita a gravação de chapa, verificação do fotolito, bem como a impressão da prova em preto e branco. O material gerado é avaliado novamente pelo Marketing. Se aprovada, a embalagem segue para a fábrica.

A Área de Compras presta uma Assessoria Interna Operacional do processo. Basicamente, sua função é manter contato com as gráficas ao enviar e receber os disquetes com a aprovação do fotolito pelo Marketing. Faz toda a negocição necessária (identificar uma gráfica, definição de prazos, fazendo cobranças, entre outros) - viabiliza essa etapa de elaboração da embalagem. " $A$ Area de Vendas é um canal informal que ajuda a detectar o desempenho da embalagem nas gôndulas dos supermercados. A empresa no Brasil pode ser considerada de pequeno porte. Isso facilita a comunicação direta e informal entre as áreas de Marketing e Vendas".

\section{Passo 4. Veto}

Caminha paralelo ao processo de desenvolvimento da embalagem. Por exemplo, se na primeira impressão a arte gráfica apresentar alterações quanto às especificações relativas à cor, essa embalagem será vetada. Quando a embalagem chega à fábrica, ela é testada, avaliada/ amostrada pelo controle de qualidade. Se estiver em desacordo com os padrões definidos pela empresa, será vetada e devolvida ao fornecedor. O veto existe nesse ponto. "Dificilmente, uma embalagem que já foi para o mercado é vetada". 
Quadro 4.3a Estrutura da empresa brasileira produtora de cereais

\begin{tabular}{|c|c|c|c|c|}
\hline \multicolumn{5}{|c|}{ DESENVOLVIMENTO DE EMBALAGEM DE CEREAIS } \\
\hline \multirow{2}{*}{$\begin{array}{l}\text { DEPTOS/ ÁREAS } \\
\text { FUNCIONAIS } \\
\text { PRINCIPAIS } \\
\text { INFLUENCIADORES }\end{array}$} & \multicolumn{4}{|c|}{ FUNÇÃO - ETAPAS DO PROCESSO DE DESENVOLVIMENTO } \\
\hline & $\begin{array}{c}\text { Estágio } 1 \\
\text { Recomendação }\end{array}$ & $\begin{array}{c}\text { Estágio } 2 \\
\text { Produçăo/Avaliação/Veto } \\
\end{array}$ & $\begin{array}{c}\text { Estágio } 3 \\
\text { Teste da Arte Final/Veto } \\
\end{array}$ & $\begin{array}{l}\text { Estágio } 4 \\
\text { Arte Final }\end{array}$ \\
\hline Marketing & $\begin{array}{l}\text { "briefing" - desenho } \\
\text { gráfico da embalagem }\end{array}$ & & & \\
\hline $\begin{array}{c}\text { Desenvolvimento ou } \\
\text { Qualidade }\end{array}$ & & $\begin{array}{l}\text { avaliação/definição/veto } \\
\text { estrutura e informações técnicas }\end{array}$ & & \\
\hline Jurídico & & $\begin{array}{c}\text { avaliação/definição/veto } \\
\text { aspectos legais, nutricionais e ligados ao } \\
\text { consumidor }\end{array}$ & & \\
\hline $\begin{array}{l}\text { Fornecedor } \\
\text { Gráfica } 2\end{array}$ & & & & $\begin{array}{l}\text { impressão da } \\
\text { embalagem final }\end{array}$ \\
\hline
\end{tabular}

Nota: Quadro elaborado a partir das informações verbais fornecidas pelo agente de produção entrevistado 


\subsubsection{Entendimento do profissional brasileiro entrevistado}

\section{Papel estratégico das embalagens de cereais matinais}

"Por sermos uma empresa produtora de cereais, desempenha um papel fundamental e absorve cerca de 95\% do 'business' - negócio. A empresa mundial está abrindo novas frentes na área de alimentos de conveniência - 'convenience foods'. Nos Estados Unidos existe muito os 'bagels', 'nutri-grain bars', 'cereal bars', 'Krispies bars'. No Brasil, também, está-se entrando com essa linha de produtos e com grande expectativa. O consumidor brasileiro consome muito doce, muito chocolate, muita bolacha. Os 'candies' acabam competindo de forma indireta com esses produtos da linha 'bars'".

Considerando que o cereal pode ser consumido a qualquer hora do dia, seja no horário de uma refeição (café da manhã, lanche, jantar) ou como uma guloseima, a proposta da empresa é retirar a expressão "matinal" e passar a colocar os dizeres "cereal - em qualquer hora do dia".

“A marca 'Kellogg' no Brasil é muito forte, mas não tanto como nos Estados Unidos, onde as vendas anuais representam bilhões de dólares. Aqui, é considerada uma empresa de pequeno porte. A marca é muito maior do que a empresa, tem um peso muito forte, é bem vista em termos nutricionais, transmite confiança ao consumidor, sinônimo de altissima qualidade - tradição em termos de cereal matinal".

As embalagens dos nossos produtos não são muito grandes. "Posso usá-las, também, como mídia, em uma campanha, para fazer promoções, ou ainda, divulgar uma extensão de linha". Além de estabelecer a comunicação com o consumidor, a embalagem possuí o papel básico de consevar as características organolépticas do produto. No Brasil, um dos problemas da categoria de cereais é a falta de informação sobre ela (valores dos cereais - aspecto nutritivo, valor da fibra na regularização do aparelho digestivo). "A empresa emprega a embalagem como uma forma de desenvolver a categoria". Nesse sentido, pode-se dizer que a embalagem representa uma fonte de informação para o consumidor. Um dos papéis da Kellogg's como líder de mercado é, justamente, desenvolver a categoria. "Temos, então, uma informação nutricional bem detalhada, painéis laterais - (1) falando sobre o papel de cada uma das vitaminas presentes em nossos produtos; (2) sobre a campanha de nutrição (o quanto é nutritivo um cereal)".

Geralmente, "o consumidor dos nossos produtos leva a embalagem dos nossos produtos até à mesa, no momento de consumir o cereal, por apresentar um visual bastante atrativo". Essa prática faz com que o papel de comunicação da embalagem com o usuário de cereais se torne efetivo.

\section{Conjunto informativo/ elementos visuais empregado nas embalagens de cereais matinais}

Em cada parte da embalagem (face principal, laterais, dorso) existe um fator, que acaba exercendo influência na composição e/ou definição dos elementos visuais impressos. 
- Conteúdo nutricional - compreende a tabela nutricional, os ingredientes e a porcentagem de recomendação diária. A definição desses elementos parte da área de Desenvolvimento \& Qualidade. A legislação determina que o produtor coloque as informações nutricionais tendo como base o consumo por 100 gramas do produto. "Em nossas embalagens acrescentamtos $e$ recomendamos que o usuário consuma, diariamente, uma porção de 30 gramas de cereal. Essa porção representa, em medidas caseiras, uma xícara de cereal. Foi empregada a medida xicara por ela representar uma medida comum de receita. A informação nutricional do cereal por porção de consumo é expressa diretamente, evitando que o consumidor faça cálculos. Normalmente, o consumidor não consome o produto na xicara. Nós estamos divulgando o uso do "bowl" - tigela, utensilio tipicamente empregado pelo consumidor norte-americano de cereais. A empresa já fez 2 promoções nesse sentido".

- Painel principal da embalagem - logotipos, personagens, colorido, entre outros. Quando a marca do produto é global, existe influência externa, ou seja, esses elementos visuais vêm previamente definidos e, portanto, não podem ser alterados. Por exemplo, no cereal "Sucrilhos" são pré-estabelecidos o personagem "Tony the Tiger" e o conjunto de cores empregados. Às vezes, o personagem pode sofrer alguma adaptação, dependendo da situação. Um exemplo bem recente, refere-se à Copa Mundial de Futebol. A fotografia do personagem "Tony the Tiger" apresentava-o jogando bola. Também é mantido um padrão quanto aos itens logotipos - marca Kellogg's e nome do produto, a chamada/ "splash" de vitaminas, foto de apresentação/ descrição do cereal "Sucrilhos". "É uma estratégia para manter uma unidade - a imagem da empresa".

- Face lateral e dorso da embalagem: estas faces da embalagem são empregadas como mídia. O conteúdo e sua apresentação podem estar voltados para uma promoção, divulgação, ou ainda, chamada para outros produtos de uma extensão de linha. Não possuí um visual padrão em termos da definição de cores, acabamento, letra e mensagem.

"Considerando todas as faces das nossas embalagens, a linguagem é considerada padronizada, ou seja, ela estará sempre voltada para o público-consumidor daquela linha de cereal".

\section{Conjunto informativo/ elementos visuais: idéias comunicadas ao consumidor}

Basicamente, a idéia transmitida ao mercado consumidor é justamente "a imagem de confiança $e$ seriedade. $O$ usuário dos nossos produtos confia na qualidade do produto ('posso dar para meu filho consumir') pois a empresa se preocupa em informar seu consumidor com muito detalhes acerca dos seus produtos; seriedade". A empresa tem uma linha de conduta, isto é, uma ética, que fica explícita na embalagem. Além disso, transmite liderança, pois, está sempre inovando seja em termos de embalagem, conteúdo, promoções.

\section{Principais aspectos na escolha dos elementos visuais inseridos na embalagem}

Os principais aspectos que influenciam a definição dos elementos visuais impressos nas embalagens de cereais são:

- "guidelines"/ normas: definição de personagens para marcas mundiais como os cereais "Froot Loops", "Corn Flakes", "Frosted Flakes"/ "Sucrilhos". Para outros produtos, como por exemplo o cereal "Choko Krispies", a empresa tem flexibilidade de estar definindo os elementos 
visuais do produto. "É considerada uma marca forte na sua categoria". Em alguns paises, esse mesmo produto é chamado "Cocoa Krispies". Foi definida, pela Agência de Publicidade com sede no México, uma única embalagem do cereal "Choko Krispies" para os países México, Argentina e Brasil. No México, o personagem "Melvin" passa a imagem de um elefante "malandro", "mais adulto" e "menos fofinho". O público-alvo é de adolescentes. No Brasil, o personagem adquire uma personalidade "mais infantil". Foi uma mudança radical em termos de imagem do personagem e ocorreu em função de logística, isto é, economia de escala. Essa flexibilidade tem o seu lado positivo e negativo. "Como aspecto positivo, ressalta-se o fato do personagem poder ser modernizado/ estilizado de acordo com as exigências do mercado consumidor regional elou global. Por outro lado, a descaracterização do personagem leva à falta de identificação (perde um pouco da história, do 'equity') do produto, principalmente, no caso de embalagens bilingues. A logistica tem como objetivo obter economia em termos de estocagem. A longo prazo, essa flexibilidade pode enfraquecer a imagem do cereal".

- aspectos legais ou obrigatórios - a legislação existente no país obriga a colocação de uma série de informações nas embalagens de cereais. Por exemplo, o tamanho da letra para o peso líquido do produto deve representar um quinto do tamanho da letra do nome convencional do cereal. É obrigatória a apresentação da composição/ ingredientes do produto, a especificação do valor nutricional do cereal em 100 gramas de cereal, entre outras.

- aspectos técnicos - decorrem da área de Desenvolvimento \& Qualidade e obedecem a um certo padrão quanto à forma de serem apresentadas. Por exemplo, tipologia especifica para os logotipos - marca e nome do produto, foto descrevendo o conteúdo contido no interior da embalagem é impressa numa determinada posição e na face principal da embalagem, prazo de validade vem sempre na aba superior de abertura e fechamento do cartucho. Para a empresa é uma convenção a ser adotada. Em relação às marcas concorrentes ofertadas pelo mercado consumidor, representa um ponto de diferenciação. Quanto aos sacos plásticos - "liners", os ajustes aplicados na espessura desse invólucro dependem do tipo de cereal, isto é, se há a necessidade ou não de uma barreira mais forte para manutenção do aroma, da umidade, ou ainda, da consistência crocante do cereal.

- mercado consumidor/ clientes - este aspecto exerce influência na definição da resistência e do tamanho dos cartuchos (altura das gôndolas, caixa de embarque - quantidade de cartuchos).

- concorrência e ações complementares no ponto-de-venda - no geral, "nós fomos os líderes, os pioneiros no mercado. Cerca de $90 \%$ das nossas embalagens são originais, os concorrentes acabaram tomando-as como base para a elaboração das embalagens dos seus produtos. $O$ mercado de cereais matinais, hoje, é, basicamente, composto pelos nossos produtos".

\section{Composição de grupos informações e seus correspondentes elementos}

As embalagens podem ser divididas em 3 partes:

- Face principal - compreende toda a comunicação visual, exclusivamente, voltada para o público-alvo de um determinado tipo de cereal. É a descrição do produto, que se encontra no interior da embalagem. "Procuramos apresentar esses elementos visuais de uma chamada apetitosa, para atratir a atenção do consumidor para o nosso produto. Quando é feita uma promoção via embalagem, procuramos dar o destaque necessário à mesma". Para o produtor, a face principal da embalagem vem a ser o grande visualizador do produto, ou seja, é a "face do produto". 
- “Box" nutricional - composto por elementos mais racionais, através dos quais a empresa informa o consumidor quanto ao valor nutricional do cereal.

- Face lateral e dorso da embalagem - representam a mídia, é um canal de comunicação onde a empresa tem mais liberdade de estabelecer esse contato com o consumidor. Por exemplo, "é onde posso brincar com o consumidor. $O$ usuário de cereal pode encontrar o seu 'fã' de uma modalidade esportiva, por exemplo, impresso na embalagem".

O desenvolvimento da embalagem do cereal "Sucrilhos Banana" teve como principal foco de atenção o próprio cereal. Ou seja: tropicalidade (fotos de bambus, folhagem com a imagem de uma selva), inovação, aspectos africanos. Nesse caso, o único elemento da embalagem é - o produto. Com exceção dos elementos legais.

Grupos de informações e correspondentes elementos:

- Informações legais/ técnicas: peso líquido, dados sobre o fabricante (empresa brasileira, marca registrada, CNPJ, endereço), "trade marks", composição do produto (produto ampliado para demonstrar textura), ingredientes, informações nutricionais por $100 \mathrm{~g}$. do produto.

- Apresentação do produto: composta por informações racionais (parte nutricional do produto: painel nutricional com informações agregadas pela empresa - cada nutriente em porcentagem, porção de consumo e sua correspondência em medidas caseiras), parte visual (foto do produto), parte promocional (splash de vitaminas).

- Informações para o mercado (“trade”): tamanho da embalagem, formato da caixa de embarque.

- Canal de comunicação/ informações genéricas: conjunto de elementos (objetivos de Marketing) voltados para o "meu consumidor".

- Informações de identidade visual de concorrência: elementos que facilitem o consumidor a identificar o meu produto em relação às opções ofertadas pelo mercado. Esses elementos (cor, personagens, posicionamento dos logotipos (marca e nome do produto) vem a ser a composição gráfica, o design da embalagem. Portanto, identidade visual do produto. " $A$ Kellogg's por ser uma marca lider, nossas embalagens tornaram-se uma identidade de produto e de categorias". Por exemplo, para cereais açucarados, o "Sucrilhos" é um padrão da categoria. Ou seja, a embalagem possue a cor azul, com um personagem no meio, nome bem destacado (em branco) na parte superior da caixa. Em suma, todas embalagens são muito parecidas. Quando se fala de "Corn Flakes", "nossa embalagem é padrão no mercado".

- Validade: informação à parte. Segurança, integridade do produto.

\section{Relevância dos Atributos}

Para especificar a ordem de importância/ relevância atribuída pela empresa a cada um dos elementos constituintes das embalagens de cereais matinais, o entrevistado segmentou a categoria de cereais em linhas "infantil" e "adulta".

Para as linhas "infantil" e "adulta", cabe ressaltar que o logotipo da marca "Kellogg's" apresenta uma logotipia própria, isto é, tamanhos similares e impressão sempre na mesma posição em todas as embalagens. O mesmo ocorre com o nome do produto. Esta última definição pode decorrer de 
uma determinação externa e/ou interna à empresa. Interferência externa, por exemplo, é o caso do cereal "Froot Loops", cujo logotipo é muito parecido com aquele utilizado nos Estados Unidos. Para o cereal "Sucrilhos Banana" (uma extensão da linha "Sucrilhos"), foi aproveitado o padrão interno existente na companhia sediada no Brasil. Um outro elemento-chave presente nas embalagens de cereais matinais é a "chamada"/ "splash" nutricional acerca do conteúdo de vitaminas existente no produto. Às vezes, ocorre uma pequenina diferenciação no formato dessa "chamada"/ "splash". Normalmente, ela se encontra sempre na mesma posição e com uma aparência, praticamente, inalterada.

\section{A. Linha Infantil}

* personagem: assume a principal relevância. Através desse elemento visual que o público-alvo identifica o seu produto.

- produto em si e nome do cereal: a relevância se alterna entre esses dois elementos, dependendo do enfoque a ser atribuído, cada um deles, pelo agente produtor.

- chamadas - "splashes": diferenciam a composição do produto e, consequentemente, ressaltam seus beneficios. Exemplo, a chamada "Nutriferro" presente nos cereais "Sucrilhos" e "Corn Flakes".

- logotipo da marca: transmite ao consumidor a "imagem do cereal", isto é, por intermédio da marca a empresa mostra sua preocupação em destacar que existe uma consciência voltada para $o$ aspecto nutricional do produto.

- informação promocional: estabelece o canal de comunicação com o consumidor. É feita de forma descontraída com o público-alvo daquele cereal. Por exemplo, a impressão do "fã" de uma categoria de esporte", "joguinhos", "brindes", entre outros.

- informação nutricional: a comunicação é estabelecida com os pais que escolhem os cereais para seus filhos. É feita uma análise quanto à composição nutricional do produto, bem como uma comparação do seu valor nutritivo em relação a marcas dos concorrentes.

\section{B. Linha Adulta}

- marca - nome do produto: para a linha adulta de cereais, o nome do produto recebe uma relevância maior. Por seu intermédio, a empresa atrai o consumidor que se identifica com aquela linha de produto.

- produto em si: na arte visual de apresentar o conteúdo existente no interior da embalagem, a empresa ressalta os atributos e beneficios do produto.

- chamadas - "splashes": voltado para atender a uma necessidade específica do público-alvo de um dado produto. No cereal "All Bran", por exemplo, as chamadas "rico em fibras" e "reduzido teor de sódio", atraem, justamente, consumidores preocupados com uma alimentação mais saudável e que proporcione um beneficio funcional (regularizar o funcionamento do aparelho digestivo) ao organismo. Outro exemplo, é a chamada para o "peso líquido" do cereal. A empresa utiliza esse elemento de uma forma estratégica e tática. É uma informação que pode ser melhor explorada em relação ao volume e preço praticados pelas marcas concorrentes. 
- logotipo da marca: transmite ao consumidor a "imagem do cereal", isto é, por intermédio da marca a empresa mostra sua preocupação em destacar que existe uma consciência voltada para $o$ aspecto nutricional do produto.

- reforço - "endorsement": o cereal "All Bran" recebe um selo de garantia ou reforço, isto é, seu consumo é aprovado e recomendado pela Sociedade Brasileira de Cardiologia - SBCFUNCOR - por apresentar beneficios à saúde do seu usuário.

- informação promocional: estabelece o canal de comunicação com o consumidor. É feita de forma descontraída com o público-alvo daquele cereal. No caso cereal "All Bran", o texto - "O cereal feito sob medida para você", destaca os benefícios do produto para quem tem uma vida agitada e se preocupa em ter uma alimentação saudável e que ajuda a normalizar a função do aparelho digestivo.

- informação nutricional: a comunicação é estabelecida com o próprio usuário daquela linha de cereal. O consumidor busca um maior detalhamento em termos da composição/ valor nutritivo do cereal que irá adquirir.

\section{Comunicação da Embalagem}

De um modo geral, "o consumidor de cereais é um público elitizado", ou seja, pertence às classes sociais "A" e "B". Em menor número, são identificados consumidores da classe social " $C$ ". $O$ estilo de vida e os hábitos do consumidor são considerados pelo respondente elementos auxiliares na identificação das caracteristicas, do perfil do público-alvo dessa categoria de produtos alimentícios.

Segundo o respondente, a preocupação em consumir uma alimentação saudável, possuir uma filosofia de vida voltada para o "culto ao corpo", ter morado por algum tempo nos Estados Unidos, viajar com certa frequência para o exterior (Europa, América do Norte), estar em contato com a mídia televisiva do sistema a cabo de ccomunicação, praticar esporte, ou ainda, seguir uma dieta alimentar para emagrecer (fibras, carboidratos proporcionam saciedade) são situações que exercem significativa influência no comportamento das pessoas e, consequentemente, nos seus hábitos de compra e consumo de cereais matinais.

Os produtos da linha infantil estão voltados, preferencialmente, para as crianças. Adultos, também, são identificados como usuários dessa linha de cereais. " $O$ consumidor dos nossos cereais tem $o$ hábito de consumir o produto no café da manhã, no lanche (em casa, ou na escola), à noite e/ou como uma guloseima - 'snack'”.

O "All Bran" é um cereal $100 \%$ natural e enriquecido com vitaminas e minerais. Apresenta um forte apelo funcional e está voltado para o público feminino com mais de 25 anos, que busca a regularização do funcionamento do aparelho digestivo. 


\section{Critérios de Escolha de Cereal Matinal}

Normalmente, o que leva o indivíduo a comprar e a consumir cereal é o seu sabor (muito agradável), bem como os benefícios funcionais que ele apresenta.

Em relação aos cereais da linha infantil, os elementos que se destacam são o sabor e o apelo visual/ promocional da embalagem, por intermédio dos jogos, promoções e/ou propaganda. $\mathrm{O}$ emocional está significativamente presente no momento da compra desses cereais.

Os cereais da linha adulta levam o usuário a uma compra mais racional. Esse consumidor avalia a composição nutricional do cereal de acordo com suas necessidades específicas (baixo teor de sódio, mais fibra). Por exemplo, o cereal "Muesli" destaca o aspecto natureza/ produto natural; no caso da "Granola", a prática de esporte; "All Bran", o beneficio funcional e o "Corn Flakes", a suavidade do produto. Tomando por base os atributos de cada um desses cereais, pode-se dizer que o consumidor adulto leva em consideração os beneficios dos nossos cereais, bem como acaba sendo influenciado pelas recomendações de profissionais da área médica e/ou de academias de ginástica ("personal trainner"). $O$ fato do consumidor estar preocupado com sua saúde, ou ainda, já ter o hábito de consumir cereal representam uma favorável pré-disposição em adquirir o produto. Além disso, outra forte influência é o impacto que a embalagem exerce no ponto-de-venda na tomada de decisão do consumidor.

\section{Hábito de Compra e Consumo do Consumidor}

No caso dos cereais da linha infantil, o produto é considerado uma guloseima - "snack" - saudável. O consumo de cereais é valorizado pelos pais. Por exemplo, aqueles com sabor chocolate são adquiridos para substituir o consumo de chocolate pelas crianças. Ainda, para os cereais da linha infantil, o item "sabor" representa um forte apelo de consumo. Seu emprego está agregado ao emprego de elementos promocionais como jogos e brindes inseridos nas embalagens.

Os adultos consomem o cereal para substituir e/ou complementar uma refeição (café da manhã, lanche entre refeições, á noite), ou até mesmo, como uma guloseima - "snack". Consideram os cereais um produto saudável (baixo teor de sódio), nutritivo (confere energia, possue vitaminas, minerais), rico em fibras e seu consumo é prazeiroso, com exceção do "All Bran". Quanto a este último, o adulto ressalta seu beneficio funcional. Seu consumo é visto como uma "obrigação", ou seja, um produto que faz bem ao bom funcionamento do aparelho digestivo.

Basicamente, o hábito de compra e consumo de alimentos está vinculado ao aspecto cultural do indivíduo. De acordo com o respondente, "se compararmos o padrão alimentar do norteamericano com o do brasileiro, o cereal pode não ser visto como um produto de rápido e fácil preparo. No Brasil, não temos o hábito de tomar café da manhã e quando o fazemos, é uma refeição de preparo muito simples. Por outro lado, o café da manhã convencional do norteamericano requer mais tempo para o preparo e consumo. $\dot{E}$ uma refeição que inclue ovos, bacon, torradas, panquecas, entre outros". 


\section{A Influência do SAC na Embalagem}

$\mathrm{Na}$ empresa, o Serviço de Atendimento ao Consumidor - SAC - é uma área muito importante. Representa o canal de comunicação entre o produtor e o usuário de cereal. É composto por uma pessoa, responsável por todo o processo de atendimento, via telefone ou correio, estabelecido com o consumidor. Os papéis desempenhados pelo SAC são:

- fornecer informação: assessora/ monitora, internamente, a área de Desenvolvimento \& Qualidade. Por exemplo, o consumidor comunica um problema na selagem da embalagem. Com essa informação, a área técnica pode aprimorar o desempenho da embalagem quanto aos aspectos proteção e conservação do cereal.

- complementar as informações impressas na embalagem: a legislação vigente sobre rotulagem de produtos alimentícios exige a discriminação da composição/ ingredientes do cereal. O emprego dos termos, por exemplo, "contém extrato de malte", "glúten", muitas vezes, leva o consumidor, portador de problemas de saúde (celíaco), a se comunicar com a empresa para constatar a quantidade desses elementos na composição do cereal, bem como certificar-se da possibilidade de poder ou não consumir o produto. Normalmente, o SAC complementa informações acerca da composição do produto, sobre seu processo de fabricação, quanto ao prepararo das receitas impressas nas embalagens, informa sobre os pontos-de-venda do produto, dirime dúvidas sobre as promoções veiculadas pela embalagem (completar uma coleção, ganhar uma tigela).

- prestar um serviço: "o $S A C$ representa um banco de dados ativo". Por seu intermédio, a empresa pode enviar uma mala direta e/ou captar a opinião do consumidor. O retorno fornecido pelos usuários de cereais subsidiará o agente produtor a estruturar uma ação futura, justamente, para atender melhor as necessidades e desejos do seu público-alvo.

\section{Embalagem Ideal de Cereais Matinais}

- a curto prazo: geralmente, são modificações relacionadas à arte visual da embalagem.

- embalagem ideal: um conjunto de fatores pode levar a empresa a efetuar certas modificações na embalagem. A extensão de linha de uma categoria de cereal requer o levantamento mais apurado da opinião/ entendimento dos consumidores quanto ao produto. Por exemplo, para a extensão de linha da categoria granola ("Granola Amêndoas e Canela"), "realizamos, internamente, um estudo qualitativo sobre o comportamento do consumidor. Efetuamos uma uniformização no visual das embalagens dessa linha de produtos". A embalagem adquiriu um aspecto mais moderno ("clean"), a logotipia empregada no nome do cereal recebeu traços mais fortes, o produto foi apresentado de forma mais apetitosa, bem como impressa a chamada "Tradicional" para diferenciá-lo do novo cereal - "Amêndoas e Canela". Por intermédio da chamada "Tradicional" o consumidor vê o cereal como um produto "natural". "Esse entendimento do usuário enaltece o conceito do produto".

- a médio prazo: normalmente, são modificações estruturais na embalagam dos cereais.

- embalagem ideal: nossa maquinaria é específica para elaboração de cartuchos. A inclusão de saco plástico com "zip" (fechamento após abertura), "exigiria uma renovação total em nossa linha de produção, bem como acarretaria uma inviabilização financeira $e$ 
operacional. É uma modificação estrutural a ser feita nas embalagens de cereais, porém, atualmente, não representa uma prioridade. Adotamos algumas medidas paleativas. Por exemplo, realizamos uma promoção - na compra do cereal era dado ao consumidor um 'pote' para armazenar o produto após a embalagem ter sido aberta".

Um outro projeto de modificação estrutural das embalagens de cereais matinais está relacionado à linha adulta do produto, principalmente, para familias unicelulares (consumidor que vive sozinho) e/ou de pequeno porte. "Nossa intenção é desenvolver uma embalagem que contenha peso líquido menor, para que o consumidor possa variar entre os tipos de cereais de sua preferência, bem como consumir um produto novo - fresco e crocante".

Conforme o que foi observado sobre o entendimento dos agentes de produção brasileiros e norteamericanos, foram identificadas, no geral, similaridades relativas ao processo de desenvolvimento das embalagens de cereais matinais. Em relação aos pontos em comum destacados pelos entrevistados cabe destacar os seguintes aspectos:

- conjunto informativo e seus elementos constituintes;

- relação dos atributos destacados como relevantes;

- formação dos grupos de informações.

Em uma análise mais detalhada sobre o entendimento dos entrevistados fica caracterizada a permuta entre os elementos constituintes da embalagem de alimentos. A existência de relações interdependentes entre os vários elementos envolvidos afetam a sua elaboração, bem como geram impactos no meio ambiente, por ocasião do processo da comercialização. Portanto, é uma situação que caracteriza o funcionamento do sistema.

Concluindo, fica reconhecido o pioneirismo da marca "Kellogg's" como uma empresa produtora de cereais. Levando-se em consideração o entendimento apresentado pelos agentes de produção entrevistados, pode-se considerar que a categoria de cereais matinais, nos Estados Unidos, já está desenvolvida. No Brasil, é reconhecida a preocupação da empresa em buscar $o$ seu desenvolvimento.

No próximo capítulo, com base nos resultados obtidos e já comentados, serão apresentados os aspectos conclusivos e, sobretudo, a adequação do modelo sistêmico considerado no desenvolvimento do presente estudo. 


\section{CAPÍtULO 5}

CONCLUSÕES, IMPLICAÇÕES, LIMITAÇÕES E DIRECIONAMENTOS PARA ESTUDOS FUTUROS 


\section{CONCLUSÕES}

Este Capítulo compreende as conclusões finais do estudo e que estão diretamente relacionadas com o alcance dos objetivos propostos pela pesquisadora. Com base nos resultados obtidos e levandose em consideração a atenção centrada nas reações dos consumidores brasileiros e norteamericanos, durante $\mathrm{o}$ processo de comercialização e, sobretudo, acerca das etapas de conservação, preparo, consumo e descarte do binômio produto/ embalagem, bem como no procedimento adotado pelo setor empresarial dos dois países em questão, quanto ao seu entendimento sobre a embalagem de alimentos, procedeu-se quanto à:

- identificação de similaridades e diferenças existentes nos dois grupos de entrevistados;

- adequação do modelo sistêmico;

- identificação de conclusões gerais e específicas, relativas ao comportamento de compraconsumo do consumidor por um gênero alimentício.

\subsection{Similaridades e Diferenças Encontradas}

Conforme o que foi observado sobre o entendimento dos entrevistados brasileiros e norteamericanos, foram identificadas similaridades e diferenças durante o desenvolvimento do presente estudo.

\subsubsection{Similaridades}

1. conceitos

Quanto aos conceitos analisados, o entendimento tende a ser similar entre brasileiros e norteamericanos em relação aos pontos em comum identificados e apresentados a seguir:

- aos cereais matinais foi atribuído o conceito "alimento". O produto é visto como um gênero alimentício que apresenta "importância" pela sua composição nutricional (vitaminas, minerais, isento de colesterol) e, ainda, seu consumo pode substituir uma refeição (desjejum, almoço, lanche, jantar);

- cereais matinais compreendem determinadas características básicas e padrão, tais como produto saudável (rico em vitaminas, minerais e fibra), prático para o preparo e consumo, alimenta e confere saciedade;

- "poder de saciedade" - vinculado à presença de fibras nos cereias.

\section{2. caracterização}

Em termos de sabor, os entrevistados enfatizaram os seguintes aspectos:

- sabor natural do produto foi considerado "neutro" ou "amargo" (se predomina na sua composição grãos provenientes da aveia e/ou do trigo); 
- sabor foi considerado "adocicado" quando se dá a incorporação de açúcar e/ou mel e frutas desidratadas.

\section{3. consumo}

Verificou-se que brasileiros e norte-americanos:

- consomem cereal matinal a qualquer hora do dia, puro e/ou adicionado ao leite, sucos de frutas, entre outros;

- o produto faz parte da lista de ingredientes na eleboração de preparações culinárias;

- cereais matinais com elevado teor de açúcar em sua composição, por exemplo, os denominados "Sucrilhos", no Brasil e "Frosted Flakes", nos Estados Unidos são, basicamente, voltados para o público jovem. Porém, o público adulto não deixa de ser um consumidor do referido tipo de cereal. O elevado teor de açúcar existente na composição desses cereais foi considerado prejudicial à saúde do indivíduo.

\section{4. informações impressas nas embalagens de cereais matinais}

Quanto à facilidade/ dificuldade em encontrar as informações impressas nas embalagens de cereais matinais, o entendimento tende a ser semelhante entre brasileiros e norte-americanos nos aspectos apresentados a seguir:

\section{facilidade}

- tabela nutricional e "chamadas"/ "splashes" ("rico em fibras", entre outros);

- foto do produto (tigela, cereal, leite, mel);

- nome do cereal, marca (logotipo), nome do fabricante.

\section{dificuldade}

- "preço" - sua localização é dificultada quando inserido nas gôndolas do ponto-de-venda;

- letra em tamanho pequeno - tabela nutricional, Serviço de Atendimento ao Consumidor - SAC;

- "chamadas"/ "splashes" - conjunto de cores empregado não destaca a informação dentre as demais;

- "prazo de validade" - impressão em relevo do item (informação apagada) e falta de padronização quanto ao local em que a informação é impressa na embalagem.

\section{5. in formação nutricional impressa nas embalagens de cereais matinais}

Verificou-se que brasileiros e norte-americanos:

- apresentam uma estreita coerência em relação ao entendimento sobre a adequação da informação nutricional impressa nas embalagens de cereais matinais:

- o conjunto informativo transmite ao consumidor uma noção global sobre o valor nutricional do cereal matinal; 
- emprego de unidades de medida (quilogramas/gramas, medidas caseiras) permite que o consumidor controle, de maneira geral, o consumo de calorias diárias em sua dieta alimentar.

\subsubsection{Diferenças}

1. conceitos

Quanto aos conceitos analisados, o entendimento tende a ser diferente entre brasileiros e norteamericanos nos aspectos apresentados a seguir:

- "to get your day", ou seja, "comece bem o seu dia", adquirindo energia e uma alimentação saudável

- EUA - a expressão está associada à "praticidade"/ "rapidez", pois o consumidor não dispõe de tempo para se dedicar à elaboração de preparações culinárias.

- Brasil - diz respeito à adoção de um padrão de vida moderna, que preconiza a ingestão de alimentos "funcionais" e que valoriza a prática de atividades físicas saudáveis ao organismo.

\section{2. perfil do consumidor e estilo de vida}

\section{- Brasil}

- consumidor de cereal matinal pertence às classes sociais mais abastadas economicamente falando, bem como por pessoas com maior grau de instrução. Analisam a relação custo/ beneficio nos cereais, seu valor nutricional, bem como valorizam seu papel funcional (regularização do funcionamento do aparelho digestivo);

- consumo de cereal matinal está associado à adoção de uma determinada "filosofia de vida". Pessoas denominadas de "geração saúde" - valorizam o "culto ao corpo", praticam atividades esportivas para manter a forma fisica, bem como buscam ingerir uma alimentação composta por produtos naturais, ricos em fibra e com teores reduzidos de gordura e colesterol;

- lado "lúdico" do produto - seu consumo se dá de forma descontraída e prazeirosa; alimenta e é saboroso (adocicado e crocante).

* EUA

* cereal matinal "é parte funcional da vida do americano";

* em relação ao consumidor do produto, não existe diferenciação quanto ao nível sócioeconômico e/ou educacional. Basicamente, são indivíduos que procuram administrar o fator "tempo".

\section{3. tipos de cereais matinais consumidos}

\section{* Brasil}

- aveia - tradicionalmente, consumida pelos brasileiros desde sua infância. É um produto barato quando comparado aos demais cereais ofertados e comercializados nos pontos-devenda; 
* "Muesli" e "Granola" - seu consumo reflete a adoção de uma nova filosofia de vida denominada "geração saúde", em que o "culto ao corpo" e a ingestão de alimentos "funcionais" e "naturais" tem sido muito valorizados pelo aspecto modernidade.

\section{- EUA}

- qualquer tipo de cereal é considerado um produto "básico" na dieta alimentar do norteamericano;

- flocos de milho - "Corn Flakes"/ "Frosted Flakes". O primeiro, principalmente pelos consumidores "mais velhos". Tendem a ser mais tradicionais em seu comportamento, isto é, apreciam cereais mais simples (sem um processamento mais rebuscado) e, consequentemente, aquele que seja comercializado por um preço menor.

\section{Classificação dos atributos}

Constatou-se que os brasileiros tendem a manisfestar/ expressar com maior facilidade seu comportamento durante o processo de tomada de decisão em relação à aquisição de cereais matinais, quando comparado ao do norte-americano.

\subsection{Adequação do Modelo Sistêmico}

Primeiramente, cabe ressaltar que a abordagem sistêmica empregada no desenvolvimento do presente estudo foi elaborada e testada com base nas características existentes no processo de comercialização do mercado brasileiro de bens de consumo. Nesse sentido, comparando-se os resultados obtidos, verifica-se que, a ótica brasileira dos agentes de produção e consumo revelou uma aderência maior ao modelo sistêmico em relação à dos norte-americanos.

Essa constatação é reflexo das diferenças e peculiaridades presentes no comportamento (estilo de vida, poder de compra) dos consumidores brasileiros e norte-americanos, bem como em função da estruturação do setor produtivo e, consequente, composição (diversidade de produtos oferecidos) de ambos os mercados varejistas. Ressalta-se, ainda, que a categoria de cereais matinais, nos Estados Unidos, já está desenvolvida. No Brasil, a empresa - "Kellogg", pioneira na produção de cereais - tem a preocupação de proporcionar o desenvolvimento da referida categoria de gêneros alimentícios.

Nos Estados Unidos, em virtude da atuação normativa e regulamentadora do "Food and Drug Administration - FDA" na padronização da rotulagem e definição das práticas comerciais de produtos alimentícios, pode-se dizer que é maior o grau de consciência por parte dos agentes de produção e consumo norte-americanos, em comparação com o grau de entendimento dos profissionais e consumidores brasileiros de cereais matinais.

Além disso, para o consumidor norte-americano, o cereal matinal "é parte funcional da vida do americano". Quanto ao consumidor brasileiro, o consumo do produto, ainda, está associado ao seu aspecto hedonístico (consumo prazeiroso, "lúdico") e, principalmente, a um modismo ("culto ao 
corpo", "status" do estilo de vida moderno), que valoriza a prática de atividades esportivas, o consumo de alimentos "funcionais", bem como incentiva a adoção de uma alimentação composta por produtos naturais, ricos em fibra e com teores reduzidos de gordura e colesterol. Como resultado, no Brasil, o cereal matinal é, tipicamente, consumido por indivíduos pertencentes às classes sociais mais abastadas economicamente falando, bem como por pessoas com maior grau de instrução. Nos Estados Unidos, em relação ao consumidor do produto, não existe diferenciação quanto ao nível sócio-econômico e/ou educacional. O cereal matinal é muito valorizado e compõe a dieta alimentar diária do norte-americano.

\subsubsection{Abordagem sistêmica e a visåo dos agentes de produção e consumo}

Uma análise mais detalhada dos Quadros 5.2.1 e 5.2.1a, permite concluir que, na visão empresarial e na do consumidor não existe uma perfeita sobreposição dos cinco grupos integrantes da abordagem sistêmica. Entretanto, é possivel identificar pontos comuns entre os elementos apresentados, bem como sob que ótica eles foram agrupados. Esses Quadros sumarizam a visão dos agentes de produção e consumo entrevistados acerca do aspecto de relevância dos atributos impressos nas embalagens de cereais matinais. Em relação aos consumidores de cereal matinal, levou-se em consideração a relevância atribuída classificada até o terceiro lugar.

Com base nos aspectos conceituais apontados pelos profissionais entrevistados, foram estabelecidos grupos relativos às funções exercidas pela embalagem de cereais matinais. A nomenclatura empregada engloba os elementos constituintes da proposição sistêmica, o que permite posterior análise dos mesmos, de acordo com a abordagem considerada pela pesquisadora.

O grupo "informações legais/ técnicas" tem em comum os elementos "marca" e "peso líquido" previstos na legislação, de ambos os países, voltada para alimentos. Segundo a ótica dos consumidores brasileiros e norte-americanos, no que tange à relevância dos atributos, eles procuram associar essas e outras informações legais ("validade", "composição do produto/ ingredientes") à presença de outros itens ("tamanho da embalagem", "SAC") que tornem conveniente a compra de um produto. Antes de ser adquirido, é avaliada a relação custo/ beneficio ("preço" X "peso líquido", "aplicação do produto") que o bem de consumo possa proporcionar.

Dessa forma, optou-se por manter a nomenclatura inicialmente empregada aos grupos que integram a abordagem sistêmica e buscar o seu desenvolvimento orientando-se, por exemplo, nos subsídios colhidos com os consumidores brasileiros entrevistados neste projeto. Ou seja, grupos de "informações essenciais" e "conveniência". 
Quadro 5.2.1 Relevância dos atributos, segundo os agentes de produção e consumo

\begin{tabular}{|c|c|c|c|}
\hline \multicolumn{2}{|c|}{ BRASIL } & \multicolumn{2}{|r|}{ EUA } \\
\hline PRODUÇĀO & CONSUMO & PRODUÇÃo & CONSUMO \\
\hline logotipo/ marca & comp. prod./ ingredientes & logotipo/ marca & comp. prod./ ingredientes \\
\hline nome do produto & marca; validade & nome do produto & marca; validade \\
\hline inform. nutricionais & peso líquido; preço & inform. nutricionais & peso líquido; preço \\
\hline personagens & símb./ figuras (personagens) & personagens & simb./ figuras ("endorsement") \\
\hline ofertas: brindes & composição gráfica; logotipo & ofertas: brindes & composição gráfica; logotipo \\
\hline "splashes"/ chamadas & material/ forma/ formato & peso liquido; preço & material/ forma/ formato \\
\hline "endorsement" & ofertas: brinde & receitas & ofertas: cupons \\
\hline & valor nutritivo; "splashes" & & valor nutritivo; "splashes" \\
\hline & integridade do produto & & integridade do produto \\
\hline & fabricante; nome do produto & & receitas \\
\hline & "appeal"/ apelo visual & & \\
\hline & dinâmica/visão global embal. & & \\
\hline
\end{tabular}

Quadro 5.2.1a Grupos de informações, segundo os agentes de produção

\begin{tabular}{|c|c|}
\hline BRASIL & EUA \\
\hline $\begin{array}{l}\text { "INFORMAÇÕES LEGAIS/ TÉCNICAS" } \\
\text { " "composição do produto/ ingredientes" } \\
\text { " "informações nutricionais" } \\
\text { " "peso liquido" } \\
\text { "marca" } \\
\text { "fabricante" }\end{array}$ & $\begin{array}{l}\text { "INFORMAÇŌES LEGAIS" } \\
\text { " "prazo de validade" } \\
\text { " "marca" } \\
\text { * "peso líquido" } \\
\text { " "códigos" - de barra, da embalagem } \\
\text { * “símbolos" - reciclagem, logotipo sindicato }\end{array}$ \\
\hline $\begin{array}{l}\text { “APRESENTAÇÃO DO PRODUTO" } \\
\text { " "composição gráfica" - foto, painel principal } \\
\text { " "elementos promocionais" - "splashes"/ chamadas } \\
\text { * "tabela nutricional" }\end{array}$ & $\begin{array}{l}\text { "APRESENTAÇÃO/ COMUNICAÇÃO VISUAL DO } \\
\text { PRODUTO" } \\
\text { " "nome do cereal" }\end{array}$ \\
\hline $\begin{array}{l}\text { "VALIDADE" (representa um grupo de informações) } \\
\text { * "prazo de validade" - segurança/ integridade prod. }\end{array}$ & $\begin{array}{l}\text { "COMUNICAÇÃO NUTRICIONAL" } \\
\text { " "informação nutricional" }\end{array}$ \\
\hline $\begin{array}{l}\text { "INFORMAÇÕES PARA MERCADO/ TRADE" } \\
\text { " "tamanho da embalagem" } \\
\text { " "formato da caixa de embarque" }\end{array}$ & $\begin{array}{l}\text { "COMUNICAÇÃO PROMOCIONAL" } \\
\text { " "splashes"/ chamadas; } \\
\text { * "brindes" (brinquedos, entre outros) } \\
\text { " "peso líquido" }\end{array}$ \\
\hline $\begin{array}{l}\text { "IDENTIDADE VISUAL DE CONCORRÊNCIA" } \\
\text { " "cores" } \\
\text { " "personagens" } \\
\text { " "logotipo da marca" } \\
\text { " "nome do produto" } \\
\text { * "composição gráfica" \& "design da embalagem" }\end{array}$ & $\begin{array}{l}\text { "IMAGEM DO PRODUTOR" } \\
\text { " "fabricante" } \\
\text { " "logotipo da marca" } \\
\text { " "SAC" }\end{array}$ \\
\hline
\end{tabular}


Em relação, ainda, ao grupo "conveniência", cabe ressaltar os elementos "tamanho da embalagem" e "formato da caixa de embarque" citados pelo profissional brasileiro. Para a empresa, estas informações estão voltadas, diretamente, para o preenchimento das necessidades do mercado ("trade") consumidor e, consequentemente, para a adequada logística do produto. Assim, fica reconhecida a integração presente na comunicação entre os agentes de produção e consumo.

O conjunto de elementos dos grupos "apresentação do produto" e "comunicação promocional" ressalta a preocupação de ambos os agentes com o aspecto de divulgação do cereal matinal. Dentre os elementos citados, fica evidenciado que a tônica maior está no item "splashes"/ chamadas. Essas informações são definidas pelas empresas em função do comportamento do consumidor no mercado de consumo. Ou seja, são considerados valores, atitudes, hábitos alimentares, estilo de vida, entre outros dos usuários. Nos cereais matinais, por exemplo, os "splashes"/ chamadas no tocante ao teor de vitaminas, açúcar/ calorias e/ou colesterol, além de promoverem o produto, comunicam seu valor nutricional ao consumidor. Este aspecto recebeu destacada relevância por parte do profissional norte-americano, que formou um grupo independente denominado "comunicação nutricional". Considerando-se, também, os elementos ("porções sugeridas", "integridade do produto", "valor nutritivo", "símbolos/ figuras" de instituições ligadas à área médica) ressaltados pelos consumidores entrevistados, a pesquisadora tomou a decisão de, mais uma vez, manter o nome dos grupos que abordam os aspectos de promoção ("informações promocionais") e de preocupação com a saúde ("in formaçōes educativas") dos consumidores.

Quanto aos grupos "identidade visual da concorrência", "apresentação/ comunicação visual do produto" e "imagem do produtor", verifica-se que houve por parte dos profissionais entrevistados uma preocupação em destacar a descrição do produto através de elementos gráficos ("logotipo da marca", "nome do produto", entre outros). De acordo com a ótica das empresas, essa visão é mais abrangente. São considerados aspectos para melhor posicionamento do produto no mercado. As estratégias de marketing adotadas envolvem fatores ligados ao conceito do produto (segmento de mercado, promoção, distribuição). Portanto, a impressão gráfica da marca e do nome do produto podem contribuir, favoravelmente, na visão global da embalagem, ao despertar o interesse do consumidor pelo produto ("appeal"), no ponto-de-venda. A adoção dessas estratégias é definida, também, em função da concorrência. Associado à ótica empresarial estão presentes os elementos ("personagens", "design/ composição gráfica", "appeal"/ apelo visual) ressaltados pelos consumidores no tocante à "estética" da embalagem de cereais matinais.

Concluindo, fica caracterizada a permuta entre os elementos constituintes da embalagem de alimentos. A existência de relações interdependentes entre os vários elementos envolvidos afetam a sua elaboração, bem como geram impactos no meio ambiente, por ocasião da comercialização. Portanto, é uma situação que caracteriza o funcionamento do sistema. A Figura 5.2 apresenta graficamente a adequação do modelo sistêmico em função dos resultados obtidos com o desenvolvimento deste estudo internacional comparado sobre o entendimento dos agentes de produção e consumo acerca da embalagem de alimentos. 
Modelo Sistêmico - Embalagem de Alimentos

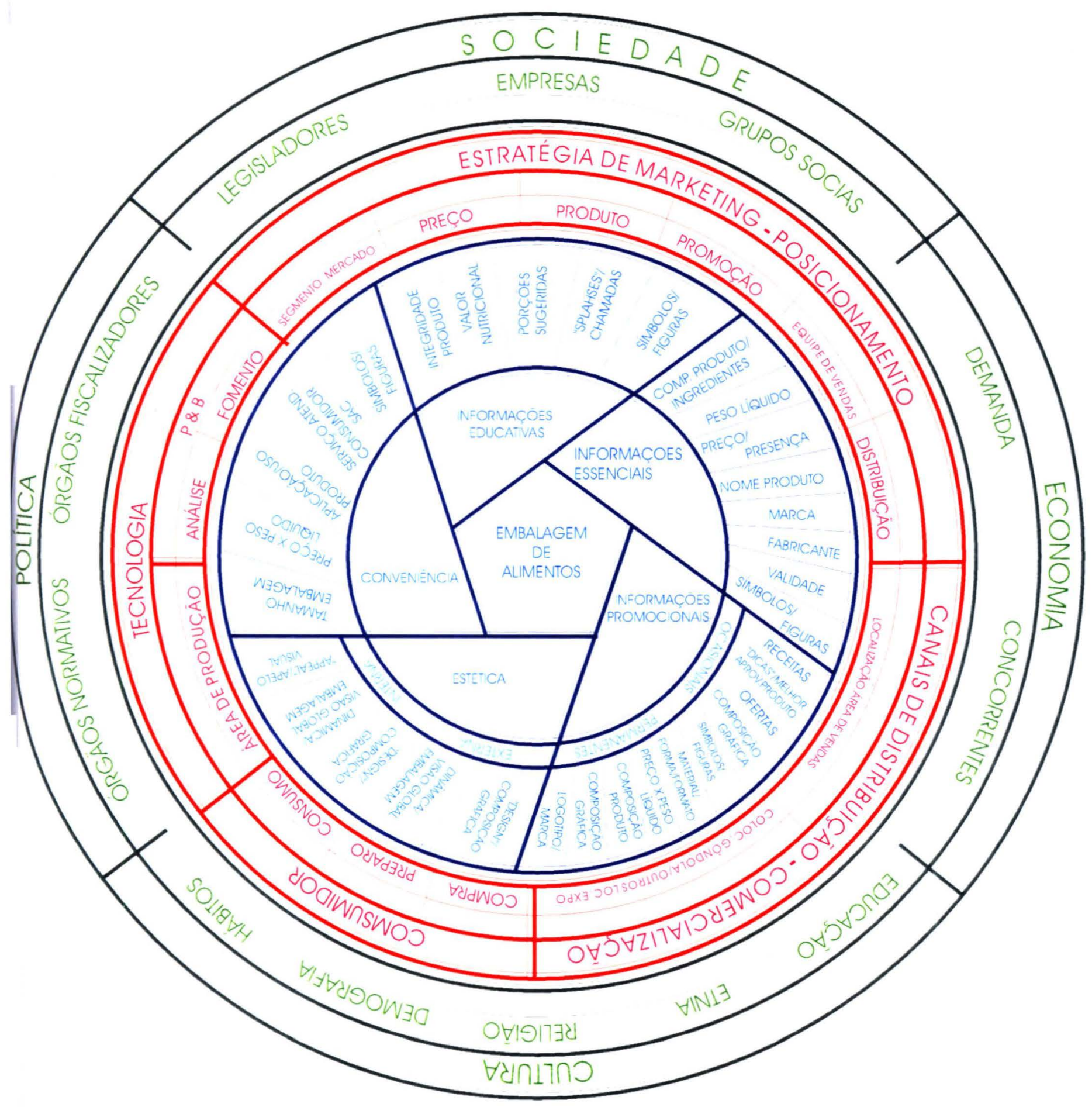

Figura 5.2 Adequação da abordagem sistêmica 


\subsection{Considerações Finais}

Neste trabalho de caráter exploratório, a embalagem de alimentos foi destacada como importante veículo de comunicação no processo de comercialização. Adotou-se uma abordagem sistêmica para ressaltar o quão complexo é o assunto sobre esse agente de estímulo diversificado no mercado. E, por meio de uma pesquisa internacional comparada, procurou-se identificar o entendimento dos consumidores e produtores brasileiros e norte-americanos acerca das embalagens de alimentos, a partir dessa visão sistêmica.

$\mathrm{Na}$ visão dos entrevistados, fica reconhecida a adoção de uma abordagem sistêmica, segundo o emprego de uma ótica peculiar aos papéis exercidos pelos agentes de produção e consumo, no decorrer do processo.

A participação efetiva do consumidor e as iniciativas tomadas pelas indústrias alimentícias, no sentido de fortalecer a comunicação com o consumidor poderão contribuir, cada vez mais, para aproximar o entendimento de produtores e consumidores. Nesse sentido, a busca constante pela atualização, modernização e padronização das normas legais vigentes para o setor de alimentos torna-se imprescindível. Essa revisão permitirá a fluência das atividades exercidas pelos profissionais responsáveis pelo planejamento-desenvolvimento das embalagens de alimentos, além de contribuir para o fortalecimento de informações, que estejam em consonância com as evoluções tecnológicas e sociais.

A função do binômio produto/ embalagem vem a ser a forma como os consumidores norteamericanos conhecem os cereais matinais da marca "Kellogg", isto é, um produto simples. Com o tempo, espera-se que os consumidores enxerguem a companhia como uma empresa produtora de alimentos de conveniência - "convenience food". No Brasil, o consumidor de cereais matinais reconhece o produto como um alimento "funcional". Portanto, fica reconhecido que a comunicação dos atributos do produto é feita em função do seu público consumidor.

Entende-se que esse veículo de comunicação vêm desempenhando um importante papel no processo da comercialização, sobretudo, nos dias de hoje com a globalização das economias de mercado. Seu papel tem sido o de estreitar a distância entre culturas diferentes. A observância desses aspectos permite que a embalagem de alimentos seja compreendida como um sub-sistema, que estabelece trocas com os demais níveis alinhados do sistema como um todo. É através da embalagem de alimentos, que se dá o impacto mercadológico do produto nela contido. 


\subsection{Implicações, Limitações e Direcionamentos para Estudos Futuros}

\subsubsection{Implicações}

Tratando-se de um estudo internacional comparado, a aplicação da abordagem sistêmica da embalagem de alimentos, como veículo de comunicação, permitiu que a pesquisadora avaliasse a dinâmica do processo de comercialização em economias globalizadas. Foi possível, também, identificar pontos comuns das abordagens encontradas e, sobretudo, sob que ótica produtores e consumidores analisam o complexo - embalagem.

Durante o processo de comercialização, os consumidores entrevistados adotam certos mecanismos que estão, diretamente, vinculados à cultura do país em que residem. Em uma economia globalizada, o conhecimento desse mecanismo, bem como o reconhecimento do perfil do consumidor com suas características diferenciadas e peculiares em termos de hábitos, padrão de consumo, estilo de vida, poder de compra, entre outros, implica a adoção de uma linguagem que atenda às expectativas, necessidades e aos desejos dos consumidores.

Cabe ressaltar os beneficios advindos com o reconhecimento de uma estrutura ordenada de preferências do consumidor, sobretudo, quando se trata de produtos comercializados em economias globalizadas. A adoção de medidas que levem em consideração a relevância dos atributos do produto, bem como as peculiaridades de cada cultura irão subsidiar a tomada de decisão do profissional de Marketing, no sentido de buscar o aprimoramento do conjunto de informações voltado para a promoção e venda dos gêneros alimentícios, segundo as exigências do mercado de consumo.

Levando-se em consideração que uma das funções da embalagem é orientar o consumidor quanto ao emprego de práticas alimentares saudáveis, a avaliação do conteúdo informativo das embalagens de alimentos, segundo a ótica dos agentes de produção e consumo, possibilitou identificar possíveis implicações da mensagem transmitida por esse veículo de comunicação sobre o comportamento do consumidor. Nesse sentido, a busca constante pela atualização, modernização e padronização acerca das informações contidas nos rótulos das embalagens de alimentos evitará que o consumidor desenvolva conceitos errôneos e/ou empregue inadequadamente um determinado produto alimentício em sua dieta alimentar diária.

Nesse sentido, sugere-se que os órgãos normativos e legisladores, as empresas, bem como os grupos sociais, que representam os consumidores, promovam estudos técnicos com vistas à adequação do conjunto informativo inserido nos rótulos, de acordo com a categoria a que pertence determinado gênero alimentício. Assim, por exemplo, no caso de suco de laranja, não seria necessário colocar a informação "colesterol zero", pois o elemento citado não faz parte da composição química/ nutricional desse tipo de produto alimentício.

Em relação ao aspecto estrutural das embalagens (cartuchos, sacos plásticos), no que diz respeito ao seu manuseio (abertura e fechamento) e, consequentemente, à conservação do produto, espera- 
se que a indústria alimentícia, em geral, passe a considerar os avanços tecnológicos existentes, no sentido de que o consumidor reconheça a incorporação de valor adicionado ao produto.

Portanto, conclui-se que a participação sincronizada dos agentes de produção e consumo representa o sinergismo do processo. $O$ conhecimento das relaçð̃es de interdependência entre os vários agentes presentes no sistema, propicia a união de produtores e consumidores num regime de parceria, na produção e comercialização de produtos alimentícios.

\subsubsection{Limitações e Direcionamentos para Estudos Futuros}

A pesquisa qualitativa, basicamente, adota um critério subjetivo (não estruturado) quanto à explicitação das áreas de abordagem, participação do pesquisador para obter as informações pertinentes ao estudo, bem como quanto ao fazer a análise e interpretação dos resultados obtidos. A definição da amostra é feita segundo uma seleção intencional dos participantes, o que pode gerar viés e/ou distorção nos resultados finais da pesquisa. Por outro lado, sua aplicação gera uma riqueza de novas descobertas, vantagem que não pode ser tão bem explorada em pesquisas estruturadas e de natureza quantitativa.

Com a metodologia estabelecida, os resultados obtidos no estudo com consumidores de cereais matinais apresentam uma provável tendência de opinião e não fatos conclusivos, não devendo ser vistos como representativos de toda a população usuária desse produto. $O$ caso prático escolhido ("Kellogg's") pode ilustrar o entendimento empresarial acerca das embalagens de alimentos. Assim, cabe ao administrador assumir a margem de risco, que por ventura possa existir, em sua decisão tomada, caso venha a adotar medidas alternativas propostas.

Por tratar-se de um estudo exploratório internacional comparado (EEIC), a utilização de entrevistas em profundidade no processo da investigação pode ter causado algumas distorções, decorrentes dos aspectos culturais inerentes aos entrevistados de cada país (Brasil e Estados Unidos), ou ainda, da interpretação do idioma inglês pela pesquisadora, no momento de decodificar as declarações obtidas. Cabe, também, ressaltar que a abordagem sistêmica empregada no desenvolvimento do presente estudo foi, originariamente, elaborada e testada com base nas características existentes no processo de comercialização do mercado brasileiro de bens de consumo.

Em face da complexidade do assunto, é provável que vários outros aspectos pertinentes ao fenômeno pesquisado, não tenham merecido o devido enfoque. Entretanto, foram ampliados os conhecimentos sobre a questão-problema.

Apesar das limitações que este trabalho possa apresentar, espera-se que o referencial teórico decorrente deste trabalho de caráter exploratório venha auxiliar no estabelecimento de algumas hipóteses, por ocasião do planejamento e desenvolvimento de novos estudos com maior profundidade, bem como para o estudo de assuntos correlatos. 


\section{REFERÊNCIAS}

Aaker DA, Day GS. Marketing research. $4^{\text {th }}$ ed. Singapore: John Wiley \& Sons; 1990. Information collection: qualitative and observational method; p. 161-83.

O Balanço positivo da embalagem. Embanews 1994; 5(42):25-32.

Bartlam MJ. Health and light foods: understanding the consumer. Br Food J 95(3):3-11, 1993.

Bennett PD. Dictionary of marketing terms. Pennsylvania: The American Marketing Association; 1988. p. 104, 140.

Benzi LD. A influência dos alimentos. F\&C Embalagem 1994; 7(74):74-6.

Berrigan J, Finkbeiner C. Segmentation marketing: new methods for capturing business markets. New York: Harper Collins Publishers; 1992.

Boroni M. O sistema embalagem. Embalagem Vende 1975; 2:84-6.

Brasil. Lei $\mathrm{n}^{\circ} 8078$, de 11 de setembro de 1990: dispõe sobre a proteção do consumidor e dá outras providências. Secretaria de Defesa do Consumidor [do Governo do Estado de São Paulo], São Paulo, 1991. p.11.

Brimson JA. Activity accounting: an activity - based costing approach. New York: John Wiley \& Sons; 1991. Activity accounting and enterprise excellence; p. 1-25.

Canton AWP, Grisi CCH, Santos RC. Identificando os níveis de envolvimento do consumidor. Mercado Global, 1989a; 16:10-4.

Canton AWP, Grisi CCH, Santos RC. Identificando os níveis de envolvimento do consumidor; parte final. Mercado Global 1989b; 16:36-9.

Castro VMF. Visão sistêmica da embalagem de alimentos no processo da comunicação: um estudo exploratório sobre a visão empresarial e a do consumidor. São Paulo; 1994. [Dissertação de Mestrado - Faculdade de Saúde Pública da USP].

Chisnall PM. Pesquisa mercadológica. São Paulo: Edição Saraiva; 1980. Introdução à pesquisa de marketing; p. 1-29.

Código do Consumidor: participação em seminário mostra interesse no setor. Superhiper 1991; $17: 40$.

Colwell J. Qualitative market research: a conceptual analysis and review of practitioner criteria. J Mark Res Soc 1990; 32:13-36.

Couig MP. The new food label. Am J Nurs 1993; 93:68-72.

Daniels PN. Reaching out to all America: coordinated nutrition education across USDA programs. J Nutr 1994; 124:1823-7.

Dawar N, Parker P. Marketing universals: consumers' use of brand name, price, physical appearance, and retailer reputation as signals of product quality. J Mark, 1994; 58:81-95.

Demetrakakes P, Bordenaro M, Spaulding M. A look back, a look ahead. Packaging 1994; 39:814. 
Dichter E. Packaging: the sixth sense? A guide to identifying consumer motivation. Boston: Cahners Publishing; 1975. p.77-85.

Dil/ Research International/ Alusa Produto \& Embalagem: pesquisa sobre embalagens e consumo. São Paulo; 1992-1994 e Santiago; 1994. Brasil-Chile; 1994. p. 1-21.

Engel JF, Blackwell RD, Miniard PW. Consumer behavior. $6^{\text {th }}$ ed. Chicago: The Dryden Press; 1990. p.63-8.

Engel JF, Blackwell RD, Miniard PW. Consumer behavior. $8^{\text {th }}$ ed. Chicago: The Dryden Press; 1995a. Consumer decision processes; p. 137-74.

Engel JF, Blackwell RD, Miniard PW. Consumer behavior. $8^{\text {th }}$ ed. Chicago: The Dryden Press; 1995b. Need recognition and search; p. 175-203.

Engel JF, Blackwell RD, Miniard PW. Consumer behavior. $8^{\text {th }}$ ed. Chicago: The Dryden Press; 1995c. Pre-purchase alternative evaluation; p. 205-33.

Engel JF, Blackwell RD, Miniard PW. Consumer behavior. $8^{\text {th }}$ ed. Chicago: The Dryden Press; 1995d. Purchase; p. 235-60.

Engel JF, Blackwell RD, Miniard PW. Consumer behavior. $8^{\text {th }}$ ed. Chicago: The Dryden Press; $1995 f$. Consumption, satisfaction, and divestment; p. 261-90.

Erickson G. Do packages tell the truth? Packaging 1990; 35:21.

Food guide pyramid replaces the basic 4 cicle. Food Technol 1992; 46:64-7.

Food Marketing Institute/Better Homes and Gardens $A$ study of information sources, planning and purchasing. Washington DC; 1988. p.10-2.

Gade C. Psicologia do consumidor. São Paulo: EDUSP; 1980.

Gerstman R apud Gershman M. Packaging: positioning tool of the 1980s. Manage Rev 1987; 76:36.

Green PE, Tull DS. Research for marketing decisions. $3^{\text {th }}$ ed. Englewood Cliffs: Prentice-Hall; 1975. p. 88-118.

Guia de embalagem - Brasil 1995. Embanews 1995. p. 16, 38-9. (Edição Especial).

Guss LM. Packaging is marketing. New York: American Management Association; 1967. p.32-47.

Hrovat KB, Harris KZ, Leach AD, Russell BS, Harris BV, Sprecher DL. The new food label, type of fat, and consumer choice. A pilot study. Arch Fam Med 1994; 3:690-5.

Information Resources, Inc. Battle Creek, 1998.

Kirk J. Kellogg pinches pennies. Adweek 1994; 35(29):2.

Kirk J. Kellogg double play. Adweek 1995; 36:6.

Kohls J, Buller P. Resolving cross-cultural ethical conflict: exploring alternative strategies. J Business Ethics 1994; 13:31-8.

Kotler P. Marketing - edição compacta. São Paulo: Atlas; 1990a. Tarefas e conceitos da administração de marketing; p. 31-47.

Kotler P. Marketing - edição compacta. São Paulo: Atlas; 1990b. Mercados de bens de consumo e o comportamento do comprador; p. 97-129. 
Kotler P. Administração de marketing: análise, planejamento, implementação e controle. $3^{\mathrm{a}}$ ed. São Paulo: Atlas; 1995. Análise do mercado consumidor e do comportamento do comprador; p. 206-40.

Kotler P. Pensar globalmente, atuar localmente. HSM Manage 1997; 1:7-12.

Kraft FB, Goodell PW. Identifying the health conscious consumer. J Health Care Mark, 1993; 13:18-25.

Langbo AG. Touring the world with Tony the Tiger. Across the Board 1995; July/Aug:56.

Laurenti R, Mello Jorge MHP, Lebrão ML, Gotlieb SLD. Estatísticas de saúde. $2^{\mathrm{a}}$ ed. São Paulo: EPU; 1987.

Levy AS, Fein SB, Shucker RE. Performance characterisitcs of seven nutrition label formats. J Public Policy Mark 1996; 15:1-15.

Lewis CJ, Yetley EA. Focus group sessions on formats of nutrition labels. J Am Diet Assoc 1992; 92:62-6.

Liesse J. Kellogg chief to push harder for int'l growth. Advert Age 1992; 63(34):4, 26.

Luqmani M, Yavas U, Quraeshi ZA. A convenience-oriented approach to country segmentation: implications for global marketing strategies. J Consum Mark 1994; 11:29-40.

Market suvey 1: breakfast cereals. Retail Business-Mark Rep 1993; 428:13-37.

O Marketing do desenho. Embanews 1994; 5(43):62.

Mattar FN. Pesquisa de marketing: metodologia, planejamento, execução e análise. $2^{\mathrm{a}}$ ed., São Paulo: Atlas; 1994a. A determinação do método de pesquisa, das fontes de dados e a construção dos instrumentos de coletas de dados; v.1, p. 79-100, 139-98.

Mattar FN. Pesquisa de marketing: metodologia, planejamento, execução e análise. $2^{\mathrm{a}}$ ed., São Paulo: Atlas; 1994b. Medidas e instrumentos de coleta de dados; v.1, p. 201-72.

Um mercado em mutação: a internacionalização e os reflexos na indústria brasileira de embalagens. Embanews 1997; 7(85):34-8.

Metha R, Belk RW. Artifacts, identity, and transition: favorite possessions of Indians and Indian immigrants to the United States. J Consum Res 1991; 17:398-411.

Miller C. Research guides NBC, Kellog in matching granola with 'Seinfeld'. Mark News 1993; 27(19):18.

Miller C. Food industry faces sweeping label requirements. Mark News 1994; 28(12):5, 12.

Miller JA. Labeling research: the state of the art. Cambridge: Marketing Science Institute; 1978. p.3, 63-7.

Moreira PF. O projeto de embalagem integrado ao fluxo logístico. In: $6^{\circ}$ Congresso Brasileiro de Embalagens - A Embalagem e o Futuro; 1994; São Paulo. Associação Brasileira de Embalagem ABE; 1994. p. 31-3.

Müller M. O impacto da estética da embalagem junto ao consumidor. In: $6^{\circ}$ Congresso Brasileiro de Embalagens - A Embalagem e o Futuro; 1994; São Paulo. Associação Brasileira de Embalagem ABE; 1994. p.169-170. 
Nazário G. Embalagem e saúde pública; embalagem, arte e técnica de um povo: um estudo da embalagem brasileira. São Paulo: Toga; 1985. p.33-4.

Nielsen Banco de Dados. São Paulo; 1998.

Oliveira P. Balanço semestral do setor. Aliment Tecnol 1993; 4(47):38-42.

Olsen JE, Granzin KL. Vertical integration and economic development: an empirical investigation of channel integration. J Global Mark 1994; 7:7-39.

Parasuraman A. Marketing research. New York: Addison-Wesley Publishing Company, 1986. Qualitative research; p. 240-65.

Parcels R apud Gershman M. Packaging: positioning tool of the 1980s. Manage Rev 1987; 76:37-8.

Pritchard B. Kellog's All-Bran builds a health share. Marketing 1993; Dec:12.

Punnett BJ, Shenkar O. Handbook for international management research. New York: Blackwell Business; 1996. p. 37-81.

Reid DJ, Hendricks SM. Consumer understanding and use of fat and cholesterol information on food labels. Can J Public Health 1994; 85:334-7.

O que reserva o amanhã: discussão sobre o crescimento sustentado, customização e a importância da marca fazem antever o papel da embalagem para o próximo milênio. Embanews 1997; 7(85):72.

Rheinstein PH, Bagley GP. Food labeling reforms for 1992. Am Fam Physician 1992; 45:1349-53.

Rickard L. Archway teams with Kellog. Advert Age 1995; 66(19):2.

Roth MS. The effects of culture and socioeconomics on the performance of global brand image strategies. J Mark Res 1995; 22:163-75.

Rust RT, Zahorik AJ, Keiningham TL. Mensurando o impacto financeiro da sua empresa: questões para qualidade. Rio de Janeiro: Qualitymark; 1995.

Sampson P. Qualitative research and motivation research. In: Worcester RM. Consumer market research handbook. $3^{\text {rd }}$ ed. Amsterdam: ESOMAR; 1991. p. 29-55.

Santos RC. Tendência de consumo de alimentos. São Paulo: Fundação Instituto Administração/ USP; 1991. p. 1-7. (PENSA: Série Temas para Discussão).

Santos RC. Oferecendo valor para o cliente. Mark Industrial, 1997; 3(7): 24-31.

Schiffman LG, Kanuk LL. Consumer behavior. $4^{\text {th }}$ ed. New Jersey: Prentice-Hall; 1991a. Subcultural aspects of consumer behavior; p. 429-59.

Schiffman LG, Kanuk LL. Consumer behavior. $4^{\text {th }}$ ed. New Jersey: Prentice-Hall; 1991b. Crosscultural consumer behavior: an internacional perspective; p. 461-82.

Selame J. A embalagem do futuro. F \& C Embalagem 1993; 6(61):66.

Selltiz C, Jahoda M, Deutsch M, Cook SW. Métodos de pesquisa nas relaçães sociais. São Paulo: EPU; 1974a. Planejamento de pequisa I; p. 57-90.

Selltiz C, Jahoda M, Deutsch M, Cook SW. Métodos de pesquisa nas relações sociais. São Paulo: EPU; 1974b. Coleta de dados; p. 263-311.

Senra A. Código do Consumidor: legislação. Aliment Tecnol 1994; 9(53):32-6. 
Seragini L. O universo da embalagem. Marketing 1984; 17(124):19-34.

Seragini L. Embalagem: fruto do pensamento estratégico. F\&C Embalagem 1990; 3(30):28-32.

Seragini L. A visão empresarial da embalagem. In: $6^{\circ}$ Congresso Brasileiro de Embalagens - A Embalagem e o Futuro; 1994; São Paulo. Associação Brasileira de Embalagem - ABE; 1994. p.19298.

Siegel S. Estatística não-paramétrica - para as ciências do comportamento. São Paulo: McGrawHill do Brasil; 1981.

Silverstein MJ. Companies that meet higher ante will global marketing pot. Mark News 1992; 26:13.

Simas AS, Simas FM. Como lidar com os valores de equities de uma embalagem. In: $6^{\circ}$ Congresso Brasileiro de Embalagens - A Embalagem e o Futuro; 1994; São Paulo. Associação Brasileira de Embalagem - ABE; 1994. p.214.

Slabber CF. Action on food labelling. S Afr Med J 1993; 83:133.

Spínola FA. Auto-conceito dos compradores norte-americanos e brasileiros e suas estruturas de decisão: pesquisa internacional comparada. São Paulo; 1995. [Dissertação de Mestrado - Faculdade de Economia, Administração e Contabilidade / FEA-USP].

Steinman HA. Should food labelling be made mandatory? S Afr Med J 1992; 81:59-60.

Sykes W. Validity and reliability in qualitative market research: a review of the literature. J Mark Res Soc 1990; 32:289-328.

Tayeb M. Organizations and national culture: methodology considered. New York: EGOS; 1994. p.429-46. (Organizations Studies).

Taylor MR. FDA's public health goals in evaluating health claims. Crit Rev Food Sci Nutr 1995; 35:1-5.

Testin RF, Vergano PJ. Food packaging. Food Rev 1991; 14:31-33.

Tollefson L. Health claims on food labels. Mil Med 1994; 159:213-7.

Tse DK, Belk RW, Zhou N. Becoming a consumer society: a longitudinal and cross-cultural content analysis of print ads from Hong Kong, the people's Republic of China, and Taiwan. J Consum Res $1989 ; 15: 457-472$.

Tsumori E. A embalagem como merchandising. SuperHiper 1994; 20:48-52.

Tull DS, Hawkins DI. Meaning measurement and method. London: Macmillan Publishing; 1976. Measurement and research: observation, depth interviews, projective techniques, and case study; $p$. 301-27.

deTurck MA, Goldhaber GM. Effectiveness of product warning labels: effects of consumer's information processing objectives. J Consum Affairs 1989; 23:111-26.

Vowler W. apud Embalagens em discussão. Embalagem Vende 1979 (13):10.

Wheeler ML, Franz M, Heins J, Schafer R, Holler H, Bohannon B et al. Food labeling. Diabetes Care 1994; 17:480-7.

Wheelock JV. Food quality and consumer choice. Br Food J 1992; 94:39-43. 
Williams C. Graphical nutritional labelling: the need for consumer research. Br Food J 1993; 95(6):25-30.

Yetley EA, Park YK. Diet and heart disease: health claims. J Nutr 1995; 125(3):679-85.

Zarkin GA, Dean N, Mauskopf JA, Williams R. Potencial health benefits of nutrition label changes. Am J Public Health 1993; 83:717-24.

Zikmund W, D'amico M. Marketing. $3^{\text {th }}$ ed. New York: John Wiley \& Sons; 1989. 


\section{APÊNDICE 1}

\section{CEREAIS OFERTADOS NO BRASIL E NOS EUA}


TOTAL BRASIL - OUT.JNOV. 1998

\begin{tabular}{|c|c|c|c|c|c|}
\hline & $\begin{array}{l}\text { Volume } \\
\text { (mil Kg) }\end{array}$ & $\begin{array}{c}\text { Valor } \\
\text { (mil US\$) }\end{array}$ & $\begin{array}{l}\text { "Share" } \\
\text { Volume }\end{array}$ & $\begin{array}{l}\text { "Share" } \\
\text { Valor }\end{array}$ & Observação \\
\hline Total Cereais & 15765.7 & 134909.4 & 100.0 & 100.0 & \\
\hline Sucrilhos & 4774.4 & 40772.0 & 30.3 & 30.2 & \\
\hline Nutrifoods Açúcar & 1117.5 & 5934.8 & 7.1 & 4.4 & \\
\hline Snow Flakes Nestlé & 775.0 & 6661.9 & 4.9 & 4.9 & \\
\hline Kellogg's Corn Flakes & 757.1 & 6561.1 & 4.8 & 4.9 & \\
\hline Nestlé Nescau & 700.5 & 7783.9 & 4.4 & 5.8 & \\
\hline Kellogg's Musli & 611.0 & 6723.2 & 3.9 & 5.0 & \\
\hline Choco Krispis & 527.5 & 5068.9 & 3.3 & 3.8 & \\
\hline Kellogg's All Bran & 507.7 & 4758.9 & 3.2 & 3.5 & \\
\hline Sucrilhos Chocolate & 487.9 & 4582.8 & 3.1 & 3.4 & \\
\hline Superbom Skarchitos & 486.9 & 2471.5 & 3.1 & 1.8 & \\
\hline Total Xereta & 440.0 & 2645.8 & 2.8 & 2.0 & Matinais - Angélica \\
\hline Kellogg's Granola & 426.7 & 4870.6 & 2.7 & 3.6 & \\
\hline Nestlé Corn Flakes & 369.1 & 3146.2 & 2.3 & 2.3 & \\
\hline Nestlé Fibre 1 & 216.8 & 1865.4 & 1.4 & 1.4 & \\
\hline Superbom Com Flakes & 214.0 & 1371.4 & 1.4 & 1.0 & \\
\hline Nutrifoods Natural & 207.7 & 1298.1 & 1.3 & 1.0 & \\
\hline Kellogg's Chokos & 201.3 & 2271.9 & 1.3 & 1.7 & \\
\hline Froot Loops & 170.3 & 2366.9 & 1.1 & 1.8 & \\
\hline Total Săo Braz & 163.8 & 1209.1 & 1.0 & .9 & Marca regional Nordeste \\
\hline Nutrifoods Chocolate & 162.5 & 996.4 & 1.0 & .7 & \\
\hline Nestlé Estrelitas & 161.2 & 2057.8 & 1.0 & 1.5 & \\
\hline Honey Nut'Os & 146.7 & 1706.7 & .9 & 1.3 & \\
\hline Kellogg's Tropic (*) & 134.9 & 1803.9 & .9 & 1.3 & (*) Marca da Kellogg"s \\
\hline Superbom Choco Croc & 130.5 & 703.9 & .8 & .5 & tirada do mercado em 99 \\
\hline Total Importados & 121.8 & 1044.7 & .8 & .8 & \\
\hline Total Vitalis & 113.6 & 1227.8 & .7 & .9 & Produto multi ingrediente Otker \\
\hline Nutrifoods Coco & 64.4 & 397.5 & .4 & .3 & \\
\hline Total Parmalat & 34.4 & 295.4 & .2 & .2 & Saiu do mercado/sobras estoque \\
\hline Total Mococa & 9.7 & 77.2 & .1 & .1 & Saiu do mercado/sobras estoque \\
\hline Outros & 1530.9 & 12233.9 & 9.7 & 9.1 & \\
\hline
\end{tabular}

Fonte: Dados fornecidos pelo profissional entrevistado 
USE: TOTAL HOMEMUKERS $(110,079,000)$ Potal Used in Last 6 Months Irems:

Aleond Delight

\section{asic 4}

Cap'n Crunch (Regular)

Cap'n Crunch Peanut Butter Crunch

Aople Cinnamon Cheerios
Honey Mut Cheerios

Honey Nut
Corn Chex

Pouble Chex
Frosted Rice Chex Junior

Rice chex

Rice Chex
meat chex

Cinnamon loast crunch

Cocoe Puffs

Crispy wheats in Raisins

Dinerseurs
Fiber One

Frankenberry clusters

Golden Grahams

Heartiand

kelloggs All Bran
kelloggs All Bran Extra fiber

Kelloggs Apple Cinnamon Squares

Kelloggs Apple Jacks

Kelloggs Bigg Mixx
kelloggs Bran Buds

kelloggs 8ran flakes
kelloggs Cinnamon Minibuns

kelloggs Cocoa Krispies

kelloggs Cormon Sense

relloggs Corn Pops

kelloggs oouble oip Crunch

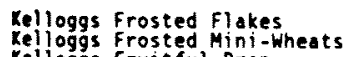

kelloggs Fruitful Bran

Relloggs Heartwise
Relloggs Honey Smack

Kelloggs Just Right
Kelloggs Kenmei Rice Bran
Kelloggs Mueslix

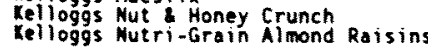

Xelloggs Nutri-Grain Raisin Bran

Kelloggs Nutri-Grain wheat a Raisin kelloggs Dat Bake
kelloggs Product 19

Xellogas Raisin Bran

Kelloggs Raisin Squares

Rellogs Rice Krispies

kelloggs strawberry squares

gther kelloggs

Rretschmer whest Germ

Cinnamon Life

Lucky Charms
Wabisco Frosted wheat Squares

Mabisco Fruit wheats

Mabisco $100 \%$ Bran
Mabisco Regular Size Shredded Wheat

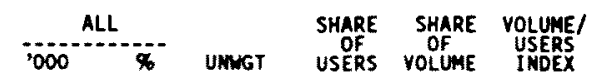

$95170 \quad 86.5 \quad 10706$

$\begin{array}{rrrrrr}4891 & 4.4 & 612 & 1.0 & .7 & 70 \\ 169 & .2 & 23 & 7 & . & 85 \\ 3368 & 3.1 & 414 & .7 & 1.5 & 75 \\ 9989 & 9.1 & 976 & 2.0 & 1.5 & 700 \\ 7115 & 6.5 & 723 & 1.4 & 1.4 & 100\end{array}$

$\begin{array}{rrrrrr}4454 & 4.0 & 481 & .9 & .8 & 89 \\ 28793 & 26.2 & 3054 & 5.8 & 10.1 & 174 \\ 9153 & 8.3 & 921 & 1.8 & 1.5 & 83 \\ 15221 & 13.8 & 1630 & 3.1 & 3.0 & 97 \\ 6521 & 5.9 & 680 & 1.3 & 8 & 62\end{array}$

$\begin{array}{rrrrrr}3084 & 2.8 & 377 & .6 & .3 & 50 \\ 1375 & 1.2 & 139 & .3 & .2 & 67 \\ 2366 & 2.1 & 250 & .5 & .5 & 100 \\ 8000 & 7.3 & 827 & 1.6 & 1.2 & 75 \\ 6042 & 5.5 & 636 & 1.2 & .7 & 58\end{array}$

$\begin{array}{rrrrrr}6866 & 6.2 & 779 & 1.4 & 1.2 & 86 \\ 4705 & 4.3 & 477 & .9 & .6 & 67 \\ 3164 & 2.9 & 287 & .6 & .6 & 100 \\ 1836 & 1.7 & 171 & .4 & .3 & 75 \\ 3597 & 3.3 & 404 & .7 & .4 & 57\end{array}$

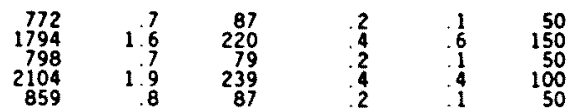

$\begin{array}{rrrrrr}7107 & 6.5 & 759 & 1.4 & 1.0 & 71 \\ 341 & .3 & 41 & 1 & 1 & 100 \\ 446 & .4 & 56 & .1 & .3 & 130\end{array}$

$\begin{array}{llllll}5122 & 4.7 & 586 & 1.0 & 1.3 & 130 \\ 1710 & 1.6 & 202 & .3 & .5 & 167\end{array}$

$\begin{array}{rrrrrr}1851 & 1.7 & 177 & .4 & .3 & 75 \\ 6588 & 6.0 & 649 & 1.3 & 1.0 & 77 \\ 2226 & 2.0 & 192 & .4 & .3 & 75 \\ 433 & .4 & 52 & 1 & 1 & 100 \\ 754 & .7 & 81 & .2 & .2 & 100\end{array}$

$\begin{array}{rrrrrr}6951 & 6.3 & 740 & 1.4 & 1.8 & 129 \\ 2646 & 2.4 & 290 & 5 & 5 & 100 \\ 4351 & 4.0 & 448 & 9 & .5 & 56 \\ 549 & .5 & 52 & .5 & .1 & 100\end{array}$

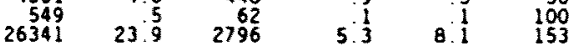

$\begin{array}{rrrrrr}6718 & 6.1 & 705 & 1.4 & 9 & 64 \\ 3369 & 3.1 & 393 & .7 & .4 & 57 \\ 4958 & 4.5 & 561 & 1.0 & .6 & 60 \\ 2305 & 2.1 & 253 & .5 & 2.4 & 80 \\ 12863 & 11.7 & 1210 & 2.6 & .6 & 100\end{array}$

$\begin{array}{rrrrrr}18034 & 16.4 & 1823 & 3.6 & 4.0 & 111 \\ 7458 & 6.8 & 799 & 15 & 1.4 & 93 \\ 1575 & 1.4 & 190 & 3 & .2 & 67 \\ 342 & .3 & 42 & 1 & .4 & 67\end{array}$

$\begin{array}{rrrrrr}2531 & 2.3 & 329 & .5 & .5 & 100 \\ 839 & .8 & 100 & .2 & .1 & 50 \\ 3570 & 3.2 & 448 & .7 & .7 & 100 \\ 5502 & 5.0 & 617 & 1.1 & .7 & 64 \\ 1921 & 1.7 & 224 & & & \end{array}$

$\begin{array}{rrrrrr}1572 & 1.4 & 175 & .3 & .2 & 67 \\ 946 & 9 & 126 & .2 & .2 & 100 \\ 644 & 6 & 79 & .1 & .1 & 100 \\ 1011 & .9 & 91 & .2 & .1 & 50 \\ 3586 & 3 & 430 & .7 & & \end{array}$

$\begin{array}{rrrrrr}20719 & 18.8 & 2240 & 4.2 & 6.3 & 150 \\ 1098 & 1.0 & 143 & .2 & .1 & 50 \\ 18189 & 16.5 & 1978 & 3.7 & 4.0 & 108 \\ 6411 & 5.8 & 775 & 1.3 & 1.3 & 100 \\ 1079 & 1.0 & 108 & .2 & .1 & 50\end{array}$

$\begin{array}{rrrrrr}1828 & 1.7 & 233 & 4 & .4 & 100 \\ 6307 & 5.7 & 679 & 1.3 & 1.1 & 85 \\ 813 & .7 & 103 & .2 & .1 & 50 \\ 4224 & 3.8 & 457 & .9 & .7 & 78 \\ 3651 & 3.3 & 357 & .7 & .4 & 57\end{array}$

$\begin{array}{rrrrrr}8319 & 7.6 & 825 & 1.7 & 1.2 & 71 \\ 2882 & 2.6 & 322 & .6 & .7 & 117 \\ 869 & .8 & 88 & .2 & .1 & 50 \\ 1144 & 1.0 & 123 & .2 & .4 & 200 \\ 5775 & 5.2 & 702 & 1.2 & 1.0 & 83\end{array}$ 
186 BREAKFAST CEREALS (COLD)

BASE: TOTAL MOMEMAKERS $(110,079,000)$

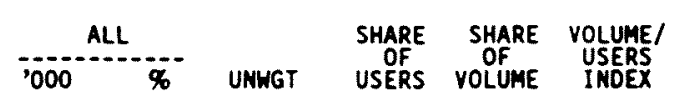

Nabisco Spoon size Shredded wheat

Nabisco Shredded wheat a Bran

Nature Valiey

Oatmeal Raisin Crisp

Post Alpha Bits

Post Bran Flakes

post Dino Pebbles

Post Fruit Fibre

Post Grapenut Flakes

Post Grape Nuts

Post Great Grains

Post Honeycombs

Post Marshmallow Alpha-Bits

Post Pet fakes Alph

Post Pebbles (Fruity)

Post Super Golden Crisp

Post Toasties

Quaker Dat Bran

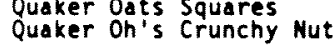

Quaker Oh's Honey Graham

Quaker 1004 Natural

Quaker Puffed wheat

Quaker Rice Bran

Other Quaker

Rais in Nut Bran

Ralston Muesti

Sunflakes
Sunfes

Teenage Mutant Ninja Turtles

Total

Total Corn

Total Raisin Bran
lotal whest

Iriples

Trix

Wheaties Honey Gold
Generic (No Label)

Store's Own Brand

Types:

Natural

Pre-sweetened

Individual Portions/Last 7 Days

$\begin{array}{lll}7404 & 6.7 & 87 \\ 1236 & 1.1 & 15 \\ 1061 & 1.0 & 129 \\ 1513 & 1.4 & 197 \\ 4110 & 3.7 & 463\end{array}$

$\begin{array}{rrr}3135 & 2.8 & 322 \\ 2004 & 1.8 & 213 \\ 384 & 3 & 30 \\ 1579 & 1.4 & 161 \\ 2276 & 2.1 & 257\end{array}$

$\begin{array}{rrr}1.5 & 1.5 & 100 \\ .2 & .3 & 150 \\ .2 & .1 & 50 \\ .3 & .2 & 67 \\ .8 & .6 & 75\end{array}$

$\begin{array}{rrr}.6 & .3 & 50 \\ .4 & .5 & 125 \\ 1 & .5 & 67 \\ 3 & .2 & \end{array}$

$\begin{array}{rrr}2207 & 2.0 & 250 \\ 9057 & 8.2 & 999 \\ 520 & .5 & 65 \\ 2035 & 1.8 & 226\end{array}$

1.4

3682

3.359

$\begin{array}{rr}1.8 & 2.1 \\ .1 & .1 \\ .4 & .5 \\ .7 & .5\end{array}$

$\begin{array}{ll}1845 & 1.7 \\ 809 & .7 \\ 2796 & 2.5 \\ 3946 & 3.6\end{array}$

181
95
252
390
832

$\begin{array}{rr}.4 & .2 \\ .2 & .1 \\ .6 & .3 \\ .8 & .5 \\ 1.6 & 1.4\end{array}$

50
50
50
63
88

$\begin{array}{rr}2234 & 2.0 \\ 1814 & 1.6 \\ 1376 & 1.3 \\ 1739 & 1.6 \\ 900 & .8\end{array}$

213
157
146
202

.3
.4
.2
.3
.1

75
100
67
100

$\begin{array}{ll}1357 & 1.2 \\ 1912 & 1.7 \\ 1919 & 1.7 \\ 1515 & 1 . \\ 433 & \end{array}$

122
260
227
185
46

.1
.5
.3
.2
1

33
125
75
67
100

852
4152
953
574

.8
3.8
9
.5
3

88
440
130
58
40

$\begin{array}{ll}1349 & 1.2 \\ 5840 & 5.3 \\ 1666 & 1.5 \\ 3406 & 3.1\end{array}$

1.2
5.3
1.5
3.1
.9

131
682
181
391
99

s60

$4.2 \quad 524$

\begin{tabular}{ll}
5.4 & 603 \\
6.8 & 864 \\
2.2 & 268 \\
1.5 & 165 \\
\hline
\end{tabular}

4
.3
3
.2
.3

100
150
50
67
75
50
125
67
80
150
117
1100
125

1607

3884

$\begin{array}{ll}5.2 & 600 \\ 3.5 & 954\end{array}$

.3
.4
.3
.3
.1

.1100

$\begin{array}{lll}2 & 2 & 100 \\ 8 & 8 & 100 \\ 2 & 2 & 100 \\ 1 & 2 & 100\end{array}$

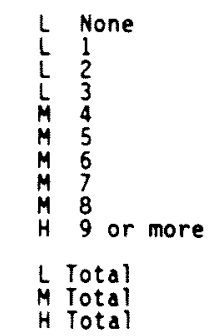

$\begin{array}{lll}16894 & 15.3 & 1998 \\ 56877 & 51.7 & 6021 \\ 83502 & 75.9 & 9416\end{array}$

$\begin{array}{rrr}15652 & 14.2 & 1800 \\ 5146 & 4.7 & 633 \\ 9324 & 8.5 & 1120 \\ 8467 & 7.7 & 933 \\ 8240 & 7.5 & 960 \\ 5857 & 5.3 & 697 \\ 5233 & 4.8 & 598 \\ 10607 & 9.6 & 1236 \\ 3117 & 2.8 & 332 \\ 23525 & 21.4 & 2397\end{array}$

$\begin{array}{rrr}1.3 & .2 & 67 \\ 1.2 & 1.1 & 92 \\ .3 & .3 & 100 \\ .7 & .6 & 86 \\ .2 & .1 & 50\end{array}$

$\begin{array}{rrr}.9 & .7 & 78 \\ 1.2 & .9 & 75 \\ 1.5 & 1.2 & 80 \\ .5 & .4 & 80 \\ 3 & .5 & 167\end{array}$

$\begin{array}{lll}1.2 & 2.2 & 183 \\ .8 & 1.9 & 238\end{array}$

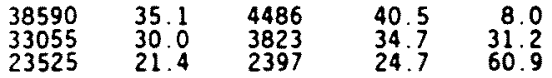


APÊNDICE 2

KELLOGG COMPANY - PORTIFÓLIO DE PRODUTOS 


\begin{tabular}{|c|c|c|c|c|c|c|}
\hline \multicolumn{7}{|c|}{$\begin{array}{c}\text { CARTON SIZE INFORMATION } \\
\text { Cereal }\end{array}$} \\
\hline $\begin{array}{l}\text { Prod. } \\
\text { No. }\end{array}$ & Product & $\begin{array}{l}\text { Ctn. } \\
\text { No. }\end{array}$ & Net Wt. & Ctn. Cube & Pkg. & UPC Code \\
\hline 01 & Corn Flakes & $\begin{array}{l}\mathrm{K}-0010 \\
\mathrm{~K}-0011 \\
\mathrm{~K}-0012 \\
\mathrm{~K}-0017 \\
\mathrm{~K}-0015 \\
\mathrm{~K}-0016 \\
\end{array}$ & $\begin{array}{l}7 \text { oz. }(198 \mathrm{~g}) \\
12 \text { oz. }(340 \mathrm{~g}) \\
18 \text { oz. }(510 \mathrm{~g}) \\
24 \mathrm{oz} .(680 \mathrm{~g}) \\
3 / 4 \mathrm{oz} .(21 \mathrm{~g}) \\
3 / 4 \mathrm{oz} .(21 \mathrm{~g})\end{array}$ & $\begin{array}{l}134.4 \\
226.1 \\
330.3 \\
427.8 \\
18.3 \\
-\end{array}$ & $\begin{array}{l}\text { Family } \\
\text { Family } \\
\text { Family } \\
\text { Family } \\
\text { Indiv. } \\
\text { Bowl } \\
\end{array}$ & $\begin{array}{l}03810107 \\
03811009 \\
03812008 \\
038000001277 \\
038000001710 \\
-\end{array}$ \\
\hline 05 & Rice Krispies & $\begin{array}{l}\mathrm{K}-0051 \\
\mathrm{~K}-9053 \\
\mathrm{~K}-0058 \\
\mathrm{~K}-0055 \\
\mathrm{~K}-0056 \\
\end{array}$ & $\begin{array}{l}10 \mathrm{oz} \cdot(284 \mathrm{~g}) \\
13.5 \mathrm{oz} \cdot(383 \mathrm{~g}) \\
19 \mathrm{oz} \cdot(539 \mathrm{~g}) \\
7 / 8 \mathrm{oz} \cdot(25 \mathrm{~g}) \\
5 / 8 \mathrm{oz} \cdot(18 \mathrm{~g})\end{array}$ & \begin{tabular}{|l|}
186.4 \\
255.9 \\
330.3 \\
18.3 \\
- \\
\end{tabular} & \begin{tabular}{|l|} 
Family \\
Family \\
Family \\
Indiv. \\
Bowl \\
\end{tabular} & $\begin{array}{l}03851007 \\
038000905308 \\
038000005350 \\
038000005718 \\
\end{array}$ \\
\hline 06 & $\begin{array}{l}\text { Complete } \\
\text { Wheat Bran Flakes }\end{array}$ & $\begin{array}{l}\mathrm{K}-0064 \\
\mathrm{~K}-0060 \\
\mathrm{~K}-0065 \\
\mathrm{~K}-0066 \\
\end{array}$ & $\begin{array}{l}12 \mathrm{oz} \cdot(340 \mathrm{~g}) \\
17.3 \mathrm{oz} \cdot(490 \mathrm{~g}) \\
1-1 / 8 \mathrm{oz}(32 \mathrm{~g}) \\
7 / 8 \text { oz. (25g) }\end{array}$ & $\begin{array}{l}148 \\
226.1 \\
18.3 \\
- \\
\end{array}$ & \begin{tabular}{|l|} 
Family \\
Family \\
Indiv. \\
Bowl \\
\end{tabular} & $\begin{array}{l}038000006401 \\
038000006005 \\
038000006715 \\
-\end{array}$ \\
\hline 08 & Raisin Bran & $\begin{array}{l}K-008 i \\
K-0082 \\
K-0087 \\
K-0085 \\
K-0086 \\
\end{array}$ & $\begin{array}{l}15 \text { oz. }(425 \mathrm{~g}) \\
20 \text { oz. }(567 \mathrm{~g}) \\
25.5 \text { oz. }(722 \mathrm{~g}) \\
1-3 / 8 \text { oz. }(39 \mathrm{~g}) \\
1-1 / 4 \text { oz. }(35 \mathrm{~g})\end{array}$ & \begin{tabular}{|l|}
134.4 \\
186.4 \\
226.1 \\
18.3 \\
- \\
\end{tabular} & $\begin{array}{l}\text { Family } \\
\text { Family } \\
\text { Family } \\
\text { Indiv. } \\
\text { Bowl } \\
\end{array}$ & $\begin{array}{l}03881008 \\
03882007 \\
038000008283 \\
038000008719 \\
-\end{array}$ \\
\hline 9 & $\begin{array}{l}\text { Apple Cinnamon } \\
\text { Squares Mini-Wheats }\end{array}$ & $\mathrm{K}-0090$ & $16.5 \mathrm{oz} .(468 \mathrm{~g})$ & 134.4 & Family & 038000009006 \\
\hline 10 & Corn Pops & \begin{tabular}{|l|}
$K-0100$ \\
$K-0101$ \\
$K-0108$ \\
$K-0105$ \\
$K-0106$ \\
\end{tabular} & \begin{tabular}{|l|}
$10.9 \circ \mathrm{oz} .(309 \mathrm{~g})$ \\
$15 \mathrm{oz} .(425 \mathrm{~g})$ \\
$19.5 \mathrm{oz} .(553 \mathrm{~g})$ \\
$1 \mathrm{oz} .(28 \mathrm{~g})$ \\
$3 / 4 \mathrm{oz} .(21 \mathrm{~g})$ \\
\end{tabular} & \begin{tabular}{|l|}
186.4 \\
255.9 \\
330.3 \\
18.3 \\
\end{tabular} & \begin{tabular}{|l|} 
Family \\
Family \\
Family \\
Indiv. \\
Bowl \\
\end{tabular} & $\begin{array}{l}038000010033 \\
038000010118 \\
038000010804 \\
038000010712 \\
-\quad \\
\end{array}$ \\
\hline 11 & Cocoa Krispies & $\begin{array}{l}\mathrm{K}-0111 \\
\mathrm{~K}-0115 \\
\mathrm{~K}-0116 \\
\end{array}$ & \begin{tabular}{|l|}
$15 \mathrm{oz} .(425 \mathrm{~g})$ \\
$1-3 / 8$ oz. $(39 \mathrm{~g})$ \\
$1-1 / 8$ oz. $(32 \mathrm{~g})$ \\
\end{tabular} & \begin{tabular}{|l|}
186.4 \\
18.3 \\
-
\end{tabular} & \begin{tabular}{|l|} 
Family \\
Indiv. \\
Bowl \\
\end{tabular} & $\begin{array}{l}038000011115 \\
038000011719 \\
-\end{array}$ \\
\hline 12 & Smacks & $\begin{array}{l}\mathrm{K}-0120 \\
\mathrm{~K}-0121 \\
\mathrm{~K}-0125 \\
\mathrm{~K}-0126\end{array}$ & $\begin{array}{l}13.1 \text { oz. }(371 \mathrm{~g}) \\
17.6 \mathrm{oz} .(499 \mathrm{~g}) \\
1-1 / 8 \mathrm{oz} .(32 \mathrm{~g}) \\
7 / 8 \mathrm{oz} .(25 \mathrm{~g})\end{array}$ & \begin{tabular}{|l|}
186.4 \\
255.9 \\
18.3 \\
- \\
\end{tabular} & \begin{tabular}{|l|} 
Family \\
Family \\
Indiv. \\
Bowl \\
\end{tabular} & $\begin{array}{l}038000012037 \\
038000012105 \\
038000012716 \\
-\end{array}$ \\
\hline 13 & All-Bran - Bran Buds & $\mathrm{K}-0130$ & $17.7 \mathrm{oz} .(501 \mathrm{~g})$ & 100.4 & Famtily & 038000013027 \\
\hline 14 & All-Bran & \begin{tabular}{|l|} 
\\
$K-0,0144$ \\
$K-0145$
\end{tabular} & \begin{tabular}{|l|}
18.3 oz. $(518 \mathrm{~g})$ \\
$1-3 / 4$ oz $(50 \mathrm{~g})$
\end{tabular} & \begin{tabular}{|l|}
134.4 \\
18.3
\end{tabular} & $\begin{array}{l}\text { Family } \\
\text { Indiv. }\end{array}$ & $\begin{array}{l}038000014116 \\
038000014710\end{array}$ \\
\hline 15 & Frosted Flakes & \begin{tabular}{|l|}
$K-0151$ \\
$K-0152$ \\
$K-0157$ \\
$K-0158$ \\
$K-0155$ \\
$K-0156$ \\
\end{tabular} & $\begin{array}{l}15 \text { oz. }(425 \mathrm{~g}) \\
20 \text { oz. }(567 \mathrm{~g}) \\
25 \mathrm{oz} \cdot(709 \mathrm{~g}) \\
31 \mathrm{oz}(879 \mathrm{~g}) \\
1-1 / 8 \text { oz. (32g) } \\
1 \mathrm{oz} \cdot(28 \mathrm{~g})\end{array}$ & \begin{tabular}{|l|}
186.4 \\
255.9 \\
330.3 \\
427.8 \\
18.3 \\
- \\
\end{tabular} & \begin{tabular}{|l|} 
Family \\
Family \\
Family \\
Family \\
Indiv. \\
Bowl \\
\end{tabular} & $\begin{array}{l}038000015106 \\
038000015205 \\
038000015274 \\
038000015328 \\
038000015717 \\
-\end{array}$ \\
\hline
\end{tabular}




\begin{tabular}{|c|c|c|c|c|c|c|}
\hline \begin{tabular}{|l} 
Prod. \\
No.
\end{tabular} & Produs: & $\begin{array}{l}\text { Ctn. } \\
\text { No. }\end{array}$ & Net Wt. & Ctn. Cube & Pkg. & UPC Code \\
\hline 16 & Special K & $\begin{array}{l}\mathrm{K}-0160 \\
\mathrm{~K}-0161 \\
\mathrm{~K}-0162 \\
\mathrm{~K}-0165 \\
\mathrm{~K}-0166\end{array}$ & $\begin{array}{l}7 \mathrm{oz} .(198 \mathrm{~g}) \\
12 \mathrm{oz} .(340 \mathrm{~g}) \\
18 \mathrm{oz} .(510 \mathrm{~g}) \\
3 / 4 \mathrm{oz}(21 \mathrm{~g}) \\
5 / 8 \text { oz. (18g) }\end{array}$ & $\begin{array}{l}134.4 \\
226.1 \\
330.3 \\
18.3 \\
- \\
\end{array}$ & $\begin{array}{l}\text { Family } \\
\text { Family } \\
\text { Family } \\
\text { Indiv. } \\
\text { Bowl } \\
\end{array}$ & {$\left[\begin{array}{l}038000016004 \\
0380000161110 \\
038000016219 \\
038000016714 \\
-\end{array}\right.$} \\
\hline 17 & Froot Loops & $\begin{array}{l}\mathrm{K}-0171 \\
\mathrm{~K}-0172 \\
\mathrm{~K}-0177 \\
\mathrm{~K}-0175 \\
\mathrm{~K}-0176\end{array}$ & \begin{tabular}{|l|}
11 oz. $(312 \mathrm{~g})$ \\
$15 \mathrm{oz} .(425 \mathrm{~g})$ \\
$19.7 \mathrm{oz} .(558 \mathrm{~g})$ \\
$15 / 16 \mathrm{oz} .(27 \mathrm{~g})$ \\
$3 / 4 \mathrm{oz} .(21 \mathrm{~g})$
\end{tabular} & \begin{tabular}{|l|}
186.4 \\
255.9 \\
330.3 \\
18.3 \\
-
\end{tabular} & $\begin{array}{l}\text { Family } \\
\text { Family } \\
\text { Family } \\
\text { Indiv. } \\
\text { Bowl }\end{array}$ & $\begin{array}{l}038000017100 \\
038000017209 \\
038000017278 \\
038000017711\end{array}$ \\
\hline 19 & Product 19 & \begin{tabular}{|l|}
$K-0191$ \\
$K-0195$ \\
$K-0196$ \\
\end{tabular} & \begin{tabular}{|l|}
12 oz. (340g) \\
$13 / 16$ oz. $(23 \mathrm{~g})$ \\
$3 / 4$ oz. (21g)
\end{tabular} & \begin{tabular}{|l|}
186.4 \\
18.3 \\
- \\
\end{tabular} & \begin{tabular}{|l|} 
Family \\
Indiv. \\
Bowl \\
\end{tabular} & $\begin{array}{r}038000019128 \\
038000019715 \\
-\quad\end{array}$ \\
\hline 20 & Puffed Wheat & $\mathrm{K}-0205$ & $3 / 8$ oz. (11g) & 18.3 & Indiv. & 038000020711 \\
\hline 21 & Puffed Rice & $K-0215$ & $7 / 16$ oz. (12g) & 18.3 & Indiv. & 038000021718 \\
\hline 22 & Cruncheroos & $\begin{array}{l}\mathrm{K}-0225 \\
\mathrm{~K}-0226 \\
\end{array}$ & $\begin{array}{l}13 / 16 \text { oz. }(23 g) \\
5 / 8 \text { oz. (18g) }\end{array}$ & $\begin{array}{l}18.3 \\
-\end{array}$ & $\begin{array}{l}\text { Indiv. } \\
\text { Bowl }\end{array}$ & $\begin{array}{l}038000022715 \\
-\end{array}$ \\
\hline 24 & $\begin{array}{l}\text { Strawberry Squares } \\
\text { Mini-Wheats }\end{array}$ & $\mathrm{K}-0240$ & 16.5 oz. (468g) & 134.4 & Family & 038000024009 \\
\hline 27 & Frosted Mini-Wheats & \begin{tabular}{|l|}
$\mathrm{K}-0272$ \\
$\mathrm{~K}-0277$
\end{tabular} & $\begin{array}{l}16 \mathrm{oz}(454 \mathrm{~g}) \\
20.4 \mathrm{oz} \cdot(578 \mathrm{~g})\end{array}$ & $\begin{array}{l}186.4 \\
226.1\end{array}$ & \begin{tabular}{|l|} 
Family \\
Family
\end{tabular} & $\begin{array}{l}038000027208 \\
038000027277\end{array}$ \\
\hline 28 & $\begin{array}{l}\text { Shredded Wheat } \\
\text { Miniatures }\end{array}$ & K-0285 & $1 \mathrm{oz} .(28 \mathrm{~g})$ & 18.3 & Indiv. & 038000028717 \\
\hline 29 & Apple Jacks & $\begin{array}{l}\mathrm{K}-0291 \\
\mathrm{~K}-0292 \\
\mathrm{~K}-0297 \\
\mathrm{~K}-0295 \\
\mathrm{~K}-0296\end{array}$ & $\begin{array}{l}11 \text { oz. }(312 \mathrm{~g}) \\
15 \text { oz. }(425 \mathrm{~g}) \\
19.1 \text { oz. }(542 \mathrm{~g}) \\
15 / 16 \text { oz. }(27 \mathrm{~g}) \\
5 / 8 \text { oz. }(18 \mathrm{~g})\end{array}$ & \begin{tabular}{|l|}
186.4 \\
255.9 \\
330.3 \\
18.3 \\
- \\
\end{tabular} & $\begin{array}{l}\text { Family } \\
\text { Family } \\
\text { Family } \\
\text { Indiv. } \\
\text { Bowl }\end{array}$ & $\begin{array}{l}038000029103 \\
038000029202 \\
038000029707 \\
038000029714 \\
-\end{array}$ \\
\hline 35 & Crispix & $\begin{array}{l}\mathrm{K}-0353 \\
\mathrm{~K}-0351 \\
\mathrm{~K}-0355 \\
\mathrm{~K}-0356\end{array}$ & $\begin{array}{l}12 \text { oz. }(340 \mathrm{~g}) \\
17.9 \text { oz }(507 \mathrm{~g}) \\
5 / 8 \text { oz. }(18 \mathrm{~g}) \\
3 / 4 \text { oz. }(21 \mathrm{~g})\end{array}$ & \begin{tabular}{|l|}
226.1 \\
330.3 \\
18.3 \\
- \\
\end{tabular} & $\begin{array}{l}\text { Family } \\
\text { Family } \\
\text { Indiv. } \\
\text { Bowl }\end{array}$ & $\begin{array}{l}038000035302 \\
038000035104 \\
038000035715 \\
-\end{array}$ \\
\hline 37 & $\begin{array}{l}\text { Raisin Squares } \\
\text { Mini-Wheats }\end{array}$ & $K-0370$ & 16.5 oz. (468g) & 134.4 & Family & 038000037009 \\
\hline 40 & All-Bran Extra Fiber & $\mathrm{K}-0401$ & $11.4 \mathrm{oz} \cdot(323 \mathrm{~g})$ & 100.4 & Family & 038000040016 \\
\hline 41 & Just Right - Fruit \& Nut & $\mathrm{K}-0410$ & $17 \mathrm{oz} .(482 \mathrm{~g})$ & 134.4 & Family & 038000041006 \\
\hline 42 & \begin{tabular}{|l|}
$\begin{array}{l}\text { Just Right - Crunchy } \\
\text { Nugget }\end{array}$ \\
\end{tabular} & $\mathrm{K}-0420$ & $14.5 \mathrm{oz}(411 \mathrm{~g})$ & 134.4 & Family & 038000042003 \\
\hline 45 & Cracklin' Oat Bran & $K-0453$ & 17 oz. (482g) & 134.4 & Family & 038000045301 \\
\hline 49 & Bite-Size Mini-Wheats & $\begin{array}{l}K-0490 \\
K-0492 \\
K-0495 \\
K-0496\end{array}$ & $\begin{array}{l}19 \text { oz. (539g) } \\
24.3 \text { oz. (688g) } \\
1-1 / 4 \text { oz. (35g) } \\
1 \text { oz. (28g) }\end{array}$ & $\begin{array}{l}186.4 \\
226.1 \\
18.3 \\
- \\
\end{array}$ & \begin{tabular}{|l|} 
Family \\
Family \\
Indiv. \\
Bowl
\end{tabular} & $\begin{array}{l}038000049002 \\
038000049200 \\
038000049712 \\
--\end{array}$ \\
\hline 52 & Fun Pak & $\mathrm{K}-0522$ & $8-9 / 16$ oz. (243g) & -- & Assort. & 1038000052200 \\
\hline 53 & Variety Pak & K-0.533 & $9-5 / 8 \mathrm{oz} \cdot(273 \mathrm{~g})$ & E & Assort. & 038000053320 \\
\hline 70 & Corn Flake Crumbs & $\begin{array}{l}\mathrm{K}-0701 \\
\mathrm{~K}-0702 \\
\end{array}$ & $\begin{array}{l}21 \text { oz. }(595 \mathrm{~g}) \\
3 \mathrm{lb} .(1.36 \mathrm{~kg})\end{array}$ & \begin{tabular}{|l|}
100.4 \\
134.4 \\
\end{tabular} & $\begin{array}{l}\text { Family } \\
\text { FoodSrv. }\end{array}$ & $\begin{array}{l}038000070105 \\
-\end{array}$ \\
\hline
\end{tabular}




\begin{tabular}{|c|c|c|c|c|c|c|}
\hline $\begin{array}{l}\text { Prod. } \\
\text { No. }\end{array}$ & Product & $\begin{array}{l}\text { Ctn. } \\
\text { No. }\end{array}$ & Net Wt. & Ctn. Cube & Pkg. & UPC Code \\
\hline 75 & Croutettes & K-0750 & $6 \mathrm{oz} .(170 \mathrm{~g})$ & 100.4 & Family & 038000075018 \\
\hline 80 & $\begin{array}{l}\text { Healthy Choice Mueslix- } \\
\text { Raisin Almond }\end{array}$ & $\begin{array}{l}\mathrm{K}-0802 \\
\mathrm{~K}-0805\end{array}$ & $\begin{array}{l}15.3 \text { oz. (434g) } \\
1-1 / 2 \text { oz. (43g) }\end{array}$ & $\begin{array}{l}134.4 \\
18.3\end{array}$ & $\begin{array}{l}\text { Family } \\
\text { Indiv. }\end{array}$ & $\begin{array}{l}038000080203 \\
038000080730\end{array}$ \\
\hline 88 & $\begin{array}{l}\text { Blueberry Squares } \\
\text { Mini-Wheats }\end{array}$ & $\mathrm{K}-0880$ & 16.5 oz. (468g) & 134.4 & Family & 038000088001 \\
\hline 91 & Smart Start & $\begin{array}{l}K-0911 \\
K-0915\end{array}$ & $\begin{array}{l}13.3 \mathrm{oz} .(377 \mathrm{~g}) \\
1.5 \mathrm{oz} .\end{array}$ & $\begin{array}{l}148 \\
18.3\end{array}$ & $\begin{array}{l}\text { Family } \\
\text { Indiv. }\end{array}$ & $\begin{array}{l}038000091100 \\
038000091506\end{array}$ \\
\hline 104 & Nutri-Grain Golden Wheat & $K-1041$ & $12.2 \mathrm{oz} .(346 \mathrm{~g})$ & 148 & Family & 038000104015 \\
\hline 106 & Nutri-Grian Almond Raisin & K.-1061 & 17.2 oz. (488g) & 148 & Family & 038000106019 \\
\hline 121 & Complete Oat Bran Flakes & $\mathrm{K}-1212$ & $14.8 \mathrm{oz} .(420 \mathrm{~g})$ & 226.1 & Family & 038000121210 \\
\hline 137 & $\begin{array}{l}\text { Healthy Choice Low Fat } \\
\text { Granola w/Raisins }\end{array}$ & $\begin{array}{l}K-1373 \\
K-1375\end{array}$ & $\begin{array}{l}18 \text { oz. }(510 \mathrm{~g}) \\
1-1 / 2 \text { oz. }(43 \mathrm{~g})\end{array}$ & $\begin{array}{l}134.4 \\
18.3 \\
\end{array}$ & $\begin{array}{l}\text { Family } \\
\text { Indiv. }\end{array}$ & $\begin{array}{l}038000137303 \\
038000137716\end{array}$ \\
\hline 138 & $\begin{array}{l}\text { Heathy Choice Low Fat } \\
\text { Granola w/o Raisins }\end{array}$ & $\mathrm{K}-1383$ & 18 oz. $(510 \mathrm{~g})$ & 134.4 & Family & 038000138300 \\
\hline 139 & Rice Krispies Treats Cereal & K.1390 & $14.8 \mathrm{oz} .(420 \mathrm{~g})$ & 226.1 & Family & 038000139000 \\
\hline 145 & Healthy Choice Biscuits & $\mathrm{K}-\overline{1450}$ & $16.5 \mathrm{oz} .(468 \mathrm{~g})$ & 148 & Family & 038000145001 \\
\hline 147 & Healthy Choice Multi-Grain & $\mathrm{K}-1470$ & $12.3 \mathrm{oz} .(349 \mathrm{~g})$ & 134.4 & Family & 038000147005 \\
\hline 168 & Honey Crunch Corn Flakes & \begin{tabular}{|l|}
$K-1682$ \\
$K-1683$ \\
$K-1685$ \\
$K-1686$ \\
\end{tabular} & $\begin{array}{l}15.1 \text { oz. }(428 \mathrm{~g}) \\
21.3 \mathrm{oz} .(604 \mathrm{~g}) \\
1-1 / 4 \mathrm{oz} .(35 \mathrm{~g}) \\
1-1 / 16 \mathrm{oz} .(30 \mathrm{~g})\end{array}$ & \begin{tabular}{|l|}
186.4 \\
255.9 \\
18.3 \\
- \\
\end{tabular} & $\begin{array}{l}\text { Family } \\
\text { Family } \\
\text { Indiv. } \\
\text { Bowl } \\
\end{array}$ & $\begin{array}{l}038000168208 \\
038000168307 \\
038000168505 \\
-\end{array}$ \\
\hline 190 & Cocoa Frosted Flakes & $\begin{array}{l}K-1901 \\
K-1905 \\
K-1906\end{array}$ & $\begin{array}{l}16.1 \text { oz. (456g) } \\
1-3 / 8 \text { oz. (30g) } \\
1 \text { oz. (28g) }\end{array}$ & $\begin{array}{l}186.4 \\
18.3 \\
- \\
\end{array}$ & $\begin{array}{l}\text { Family } \\
\text { Indiv. } \\
\text { Bowl }\end{array}$ & $\begin{array}{l}038000190100 \\
038000190506 \\
-\end{array}$ \\
\hline 193 & Razzle Dazzle Rice Krispies & $\begin{array}{l}K-1932 \\
K-1935\end{array}$ & $\begin{array}{l}13.5 \text { oz. }(383 g) \\
1-1 / 4 \text { oz. }(35 g)\end{array}$ & $\begin{array}{l}186.4 \\
- \\
\end{array}$ & $\begin{array}{l}\text { Family } \\
\text { Indiv. }\end{array}$ & 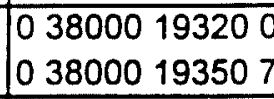 \\
\hline 201 & Lo-Sodium Corn Flakes & $K-2015$ & $11 / 16$ oz. (19g) & 18.3 & Indiv. & 038000201714 \\
\hline 918 & $\begin{array}{l}\text { Marshmallow Blasted } \\
\text { Froot Loops }\end{array}$ & $\begin{array}{l}\text { K-9181 } \\
\text { K-9185 }\end{array}$ & $\begin{array}{l}14 \text { oz. (397g) } \\
15 / 16 \text { oz. }\end{array}$ & 226.1 & $\begin{array}{l}\text { Family } \\
\text { Indiv. }\end{array}$ & $\begin{array}{l}038000918100 \\
038000918506\end{array}$ \\
\hline
\end{tabular}




\begin{tabular}{|c|c|c|c|c|c|c|}
\hline \multicolumn{7}{|c|}{$\begin{array}{c}\text { CARTON SIZE INFORMATION } \\
\text { Alternate Cereals }\end{array}$} \\
\hline $\begin{array}{l}\text { Prod. } \\
\text { No. }\end{array}$ & Product & $\begin{array}{l}\text { Ctn. } \\
\text { No. }\end{array}$ & Net Wt. & Ctn. Cube & Pkg. & UPC Code \\
\hline \multicolumn{7}{|c|}{ Breakfast Mates } \\
\hline 1 & Corn Flakes & $K-9013$ & $\begin{array}{l}3 / 4 \text { oz. }(21 \mathrm{~g}) \text { Cereal } \\
4 \text { fl. oz. }(118 \mathrm{ml}) \text { milk }\end{array}$ & & \begin{tabular}{|l} 
Breakfast \\
Mates
\end{tabular} & 038000801303 \\
\hline 17 & Froot Loops & K-8173 & $\begin{array}{l}3 / 4 \text { oz. }(21 \mathrm{~g}) \text { Cereal } \\
4 \text { fl. oz. }(118 \mathrm{ml}) \text { milk }\end{array}$ & & \begin{tabular}{|l} 
Breakfast \\
Mates
\end{tabular} & 038000817304 \\
\hline 15 & Frosted Flakes & $K-8154$ & $\begin{array}{l}1 \text { oz. }(28 \mathrm{~g}) \text { Cereal } \\
4 \text { fl. oz. }(118 \mathrm{ml}) \text { milk }\end{array}$ & & $\begin{array}{l}\text { Breakfast } \\
\text { Mates }\end{array}$ & 038000815409 \\
\hline 29 & Frosted Mini-Wheats & K-8493 & $\begin{array}{l}1 \text { oz. }(28 \mathrm{~g}) \text { Cereal } \\
4 \text { fl. oz. }(118 \mathrm{ml}) \text { milk }\end{array}$ & & \begin{tabular}{|l|} 
Breakfast \\
Mates
\end{tabular} & 038000849305 \\
\hline
\end{tabular}


APÊNDICE 3

FILTRO E ROTEIRO DE ENTREVISTA UTILIZADOS NA REALIZAÇÃO DA PESQUISA 


\section{FILTRO PARA RECRUTAMENTO DO CONSUMIDOR DE CEREAIS MATINAIS}

\section{IDENTIFICAÇÃO DO CONSUMIDOR:}

\begin{tabular}{|c|c|}
\hline $\begin{array}{l}\text { Nome: } ـ \text { Tel: } \\
\text { Endereço: }\end{array}$ & $\begin{array}{c}\text { Faira etária: } \\
\text { (em anos) }\end{array}$ \\
\hline \multirow[t]{2}{*}{ Formaçăo/Atividade Profissional: } & Orçamento/Ano: $<25.000($ ) \\
\hline & 225.000() \\
\hline
\end{tabular}

1. Como você tomou conhecimento dos cereais matinais? Quando você os prepara. adiciona açúcar?

\begin{tabular}{|l|l|l|l|l|l|l|}
\hline CEREAIS MATIN. & PROPAGANDA & RELACOES \& AMIGOS & INDICACÁO MÉDICA & \multicolumn{2}{c|}{ OUTROS (meZC.) } & \multicolumn{2}{c|}{ AD ACÚCAR } \\
\hline Flocos de Milbo & & & & & & \\
\hline Flocos Integrais & & & & & & \\
\hline Crispies Arroz & & & & & & \\
\hline Muesli & & & & & & \\
\hline Floc. Int. Passas & & & & & & \\
\hline Granola & & & & & & \\
\hline Floces Cob. Acuc & & & & & & \\
\hline Avein & & & & & & \\
\hline Outros (menc.) & & & & & \\
\hline
\end{tabular}

Entrevistador:

Você adiciona açúcar? S( ) ou N( ). Se não, por quê?? (Se diabetes, não prossiga).

2. Você comprou cereais matinais nos últimos 30 dias?

Entrevistador: prossiga se o respondente tiver comprado os cereais no ponto-de-venda.

3. Dos cereais matinais que mencionarei, quais você comprou e comeu nos últimos 30 dias? [Pedir ao consumidor que os mencione em ordem de preferência] Com que frequência você comeu esse produto nos últimos 30 dias? [Mültipla resposta]

\begin{tabular}{|c|c|c|c|c|c|c|c|}
\hline \multirow[t]{2}{*}{ CEREAIS MATINAIS } & \multicolumn{3}{|c|}{ MARCAS FAVORITAS } & \multicolumn{4}{|c|}{ FREQUÊNCIA } \\
\hline & $1^{2}$ opela & $2^{*}$ opexio & 3' opeio & Diariamente & $\begin{array}{c}\text { Semanalmente } \\
\text { (mencionar) }\end{array}$ & Quinzranimente & Mensajmente \\
\hline \multicolumn{8}{|l|}{ Flocos de Milho } \\
\hline \multicolumn{8}{|l|}{ Flocos Integrais } \\
\hline \multicolumn{8}{|l|}{ Crispies de Arroz } \\
\hline \multicolumn{8}{|l|}{ Muesli } \\
\hline \multicolumn{8}{|l|}{ Flocos Integrais c/ Passas } \\
\hline \multicolumn{8}{|l|}{ Granola } \\
\hline \multicolumn{8}{|l|}{ Flocos cobertos e/ Açúcar } \\
\hline \multicolumn{8}{|l|}{ Aveia } \\
\hline Outros (mencionar) & & & & & & & \\
\hline
\end{tabular}

Entrevistador: prossiga se a frequência de consumo do produto for pelo menos de 3 vezes na semana. 
FILTER FOR THE RECRUITMENT OF BREAKFAST CEREAL CONSUMERS

\section{IDENTIFICATION CONSUMER:}

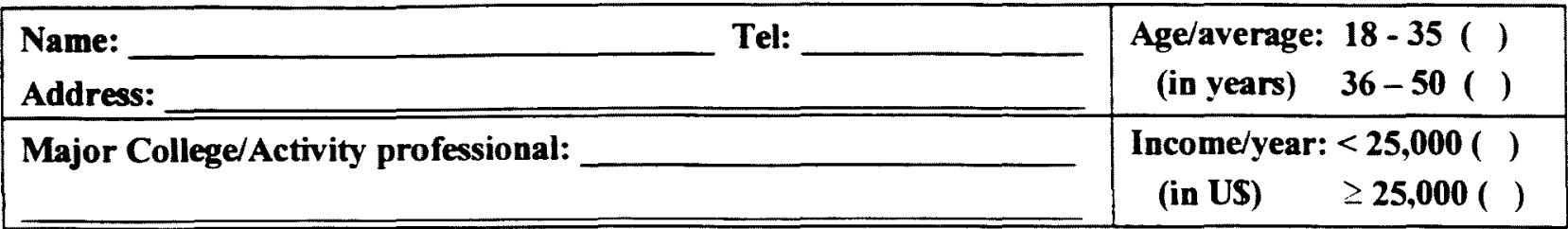

1. For breakfast cereals, how did you find out about these products? When you prepare them, do you add sugar?

\begin{tabular}{|l|l|l|l|l|l|l|}
\hline WHCB CEREALS & ADVERTISING & RELATIONS \& FRIENDS & ON DOCTOR'S ADVICE & \multicolumn{2}{|l|}{ OTHERS (ment) } & \multicolumn{2}{|c|}{ ADD SUGAR } \\
\hline Corn Flakes & & & & & & Y \\
\hline Bran Flakes & & & & & & \\
\hline Rice Puffs & & & & & & \\
\hline Muesli & & & & & & \\
\hline $\begin{array}{l}\text { Bran Flakes w/ } \\
\text { Raisins }\end{array}$ & & & & & & \\
\hline Granola Cereal & & & & & & \\
\hline $\begin{array}{l}\text { Flakes w/ Sugar } \\
\text { Coating }\end{array}$ & & & & & & \\
\hline Oat Flakes & & & & & & \\
\hline \begin{tabular}{l} 
Other (mention) \\
\hline
\end{tabular} & & & & & & \\
\hline
\end{tabular}

\section{Interviewer:}

Do you add sugar? Y ( ) or N ( ). If no, why? (If health problem such as diabetes, stop).

2. Have you bought breakfast cereals in the last 30 days?

Interviewer: continue if the respondent has made a purchase of cereals at the sales point.

3. Of the breakfast cereals which I am going to mention, which have you bought in the last 30 days to eat yourself? [Ask the consumer to give them in order of preference] How often have you eaten this product in the last 30 days? [Multiple answer]

\begin{tabular}{|l|l|l|l|l|l|l|l|}
\hline \multicolumn{1}{|c|}{ BREAKFAST CEREALS } & \multicolumn{3}{c|}{ FAVORITE BRANDS } & \multicolumn{3}{c|}{ FREQUENCY } \\
& 1st choice & 2nd choice & 3rd choice & Daily & Weekly (ment) & $\begin{array}{c}\text { Every 2 } \\
\text { weeks }\end{array}$ & Monthy \\
\hline Corn Flakes & & & & & & & \\
\hline Bran Flakes & & & & & & & \\
\hline Rice Puffs & & & & & & & \\
\hline Muesli & & & & & & & \\
\hline Bran Flakes with Raisins & & & & & & & \\
\hline Granola Cereal & & & & & & & \\
\hline Flakes with Sugar Coating & & & & & & & \\
\hline Oat Flakes & & & & & & & \\
\hline Other (mention) & & & & & & & \\
\hline
\end{tabular}

Interviewer: continue if the frequency of consumption of any type of cereal is at least three times a week. 


\section{ROTEIRO DE ENTREVISTA - CONSUMIDOR DE CEREAIS MATINAIS}

\section{INTRODUÇÃO}

$\Rightarrow$ Fazer apresentação do estudo e do pesquisador

$\Rightarrow$ Solicitar e agradecer a colaboração do consumidor

$\Rightarrow$ Explicar, em linhas gerais, os objetivos do estudo

\section{FASE DE RAPPORT ( Aquecimento)}

$\Rightarrow$ Quando eu falo em "alimento" o que vem à sua cabeça? (espontâneo) O que mais? Explorar. [Em caso de mencionar cereais] Por quê você disse cereais matinais?

\section{CATEGORIA DE CEREAIS MATINAIS}

$\Rightarrow$ Como você definiria um cereal matinal para uma pesssoa que não conhece nada sobre esse produto? [Se $o$ respondente não mencionar sabor, tamanho, formato, embalagem, ocasião de consumo, quem consome, solicitar comentários quanto a esses itens]

$\Rightarrow$ Qual é, na sua opinião, a principal função de um cereal matinal? Por quê diz isso? [Aprofundar os comentários do respondente usando a expressão: Como assim?, você poderia explicar melhor, dando um exemplo?]

$\Rightarrow \mathrm{O}$ que eles têm de bom? E o que mais? E o que têm de ruim? E o que mais?

\section{CRITÉRIOS DE ESCOLHA DE CEREAL MATINAL}

\subsection{RELEVÂNCIA DOS ATRIBUTOS}

$\Rightarrow$ Nesta etapa da entrevista, eu gostaria de saber um pouco sobre a maneira como você escolhe os produtos que você compra. Vamos fazer de conta que estamos na frente da gôndola de supermercado onde estão várias marcas de cereais matinais. Na sua opinião, quais elementos são os mais importantes para você na hora de escolher o cereal que vai comprar? Por quê diz isso?

[Verificar aspectos como: é mais alimento, complemento alimentar, bom para a saude, prático no preparo, nutritivo - rico em fibras e vitaminas, forma formato da embalagem, cores, objetos/ figuras, simbolos, tamanho da letra, marca, prazo de validade, valor mutricional, composição do produto/ ingredientes, sugestōes de preparo/ receitas, fabricante, serviço de atendimento ao consumidor, emprego de expressães "fonte de", "sem colesterol". Anotar em um cartão as informaçães mais e menos importantes. Pedir ao consumidor que justifique os niveis de relevância atribuidos a cada conjunto de informações]

* téc.: hierarquia de importância de atributos

\section{CONHECIMENTO E HÄBITOS DE COMPRA E CONSUMO}

$\Rightarrow$ Qual(is) cereal(is) matinal(is) você conhece? (espontâneo). Qual mais? Explorar. [Conjunto de cartões com os nomes de marcas de cereais matinais]

$\Rightarrow$ E quais os que você consome? Por quê consome estes? [Mostrar os cartões com as marcas mencionadas. Procurar identificar caracteristicas que relacionem o consumo do produto como "uma alimentação saudável e prática", tais como: valor nutricional, alimento rico em fibras e vitaminas, facilidade no preparo, pronto para o consumo, porçôes de consumo]

$\Rightarrow$ Vamos, agora, colocar em ordem estas diferentes marcas em termos de: mais sabor/ menos sabor; mais saudável/menos saudável; mais caro/ mais barato; embalagem bonita/ feia, de acordo com as informações mencionadas sobre os elementos mais importantes para você na hora de escolher o cereal que vai comprar. * tec: hierarquia de importância de atributos

\section{PERCEPÇÃo do CONCEITO de PROdUTO}

$\Rightarrow$ Especificamente em relação ao(s) cereal(is) que você menciou comprar e consumir, como você o(s) definiria? Por quê diz isso? [Aprofundar os comentários do respondente usando a expressão: Como 
assim?, você poderia explicar melhor dando um exemplo?]

$\Rightarrow \mathrm{Na}$ sua opinião, como são as pessoas que compram e consomem esse(s) tipo(s) de cereal matinal? [Considerar o(s) nome(s) mencionado(s) pelo respondente na questao do item 5]

[Solicitar comentários do respondente, se não mencionar: classe social, grau de instrução, pratica esporte, trabalha fora de casa, tipo de alimento que consome, segue uma dieta alimentar, idade, renda, outros]

\section{PERCEPÇÃo de EMBALAGEM}

$\Rightarrow$ Pensando apenas na embalagem: o que você lembra de cada uma das embalagens destas marcas? [Mostrar cartōes com as marcas apontadas pelo respondente]

[Anotar, separadamente, os diferentes elementos lembrados sobre cada embalagem, como: escrita, desenho, formato, chamadas sobre o valor nutricional, emprego de expressões, marca, prazo de validade, composição do produto/ ingredientes, sugestões de preparo/ receitas, expressões como "sem colesterol", "fonte de", indicação de porções de consumo, fabricante. Aprofundar os comentários do respondente quanto a esses elementos.]

$\Rightarrow$ Na sua opinião, qual o papel da embalagem, quando vai adquirir um cereal matinal? [Procurar levantar informações referentes aos aspectos: "proteção", "conservação", "fonte de informação", " fornecer um serviço ao consumidor"]

$\Rightarrow$ Que informações você encontra com mais facilidade? E com menos facilidade? [Considerar a marca escolhida: pedir ao consumidor que relacione as informações para ambas as situações e que comente a experiência vivenciada - facilidade e dificuldade encontradas]

$\Rightarrow$ A forma como a informação nutricional está impressa na embalagem, orienta você quanto à quantidade adequada do cereal a ser ingerida numa dada refeição [café da manhã, lanche]? [Procurar levantar informações como: escrita, tamanho da letra, porções de consumo, unidade de medida, outros]

$\Rightarrow$ Todas as informações, até agora mencionadas por você, poderiam ser agrupadas de acordo com o papel que desempenham? Como agruparia essas informaçðes?

[Atencão: considerar como "papel" da embalagem de cereais: "proteção", "conservação", "fonte de informação", "fornecer um serviço ao consumidor", "preenchimento de exigências legais", "atratividade", outros. Anotar em um cartão os grupos formados pelo consumidor, a partir das informações existentes na embalagem escolhida]

\section{EMBALAGEM IDEAL DE CEREAIS MATINAIS}

$\Rightarrow$ Com relação ao(s) cereal(is) que você mencionou comprar e consumir, para você, que outras informações seriam colocadas na embalagem desse(s) produto(s) além das que já existem? Quais? [Procurar levantar os elementos que auxiliariam o consumidor nos momentos de compra e consumo de cereal]

$\Rightarrow$ Ainda, com relação ao(s) cereal(is) que você mencionou comprar e consumir, de que forma você faria a disposição/ apresentação das informações [inclusive as mencionadas pelo respondente na questão anterior] em uma embalagem de cereais? [Pedir ao consumidor que exemplifique e comente a sugestão fornecida, quanto à disposição dos elementos mencionados]

\section{A INFLUÊNCIA DO SAC NA EMBALAGEM}

$\Rightarrow$ Para você, qual o papel do Serviço de Atendimento ao Consumidor - SAC? [Procurar levantar informações como: prestar serviço, fornecer informação, complementar as informações impressas na embalagem, outros]

$\Rightarrow$ Você já utilizou o SAC das empresas produtoras de cereais? [considerar $o(s)$ cereal(is) que o consumidor mencionou comprar e consumir]. Que tipo de problema levou-a a recorrer ao SAC? [Pedir ao consumidor que comente sobre o fato que a levou a contar com o $S A C]$

$\Rightarrow$ Que tipo de informação sobre os cereais matinais poderia ser complementada pelo SAC? [Pedir ao consumidor que mencione a(s) informação(es) e justifique sua resposta]

Muito obrigada, sua opnião será de grande ajuda. 


\section{SCRIPT OF THE INTERVIEW - CONSUMER OF BREAKFAST CEREALS}

\section{INTRODUCTION}

$\Rightarrow$ Presentation of the study and the researcher

$\Rightarrow$ Request the help of the consumer and thank her

$\Rightarrow$ Explain, in general terms, the aims of the study

\section{WARM-UP OR RAPPORT PHASE}

$\Rightarrow$ When I say "food products" what comes into your mind? (spontaneous) What else? Explore. [In case cereals are mentioned] Why did you say breakfast cereals?

\section{CATEGORY OF BREAKFAST CEREALS}

$\Rightarrow$ How would you define/describe a breakfast cereal for someone who knows nothing about it? [If the respondent fails to mention flavor, size, format, packaging, consumption opportunities, who consumes, ask for comments on these items]

$\Rightarrow$ What in your opinion is the main function/purpose of a breakfast cereal? Why? [Go deeper into the comments by using the expression how? Can you explain better, giving an example?]

$\Rightarrow$ What is good about breakfast cereals? Anything else...? And what is bad about breakfast cereals? Anything else?

4. CRITERIA FOR CHOOSING A BREAKFAST CEREAL

4.1. RELEVANCE OF THE ATTRIBUTES

$\Rightarrow$ In this part of the interview I would like to know a little more about the way you choose the products you buy. I want you to image that you're in front of a supermarket shelf where there are various brands of breakfast cereals. In your opinion, what are the most important elements for you when you choose the cereal which you are going to buy? Why?

[Check elements like: it's more nourishing, food supplement, healthy, practical to prepare, nutritional, the formal format of the packaging, colors, objects/ figures, symbols, brand, expiration date (validity), letter size, composition of product/ingredients, preparation suggestions/ recipes, manufacturer, customer service, use of expressions "source of", "no cholesterol". Note on a card the more and less important information. Ask the consumer to justify why certain information is more and other information is less relevant]

*technique: hierarchy of the importance of attributes

\section{KNOWLEDGE OF PURCHASE AND CONSUMPTION HABITS}

$\Rightarrow$ Name as many breakfast cereals as you can (spontaneous) Any others. Explore [Sets of cards with the names of the breakfast cereal brand names]

$\Rightarrow$ And which do you eat? Why do you eat these?

[Show the cards with the mentioned brands. Attempt to identify characteristics which relate to the consumption of the product as a "healthy and practical food": nutritional value, rich in fiber and vitamins, easy to prepare. ready to eat, consumption portions]

$\Rightarrow \quad$ Let's now rank these different brands in terms of the most and least tasty, the most and least healthy, the most expensive and the cheapest, the most and least attractive packaging. According to the information mentioned, which are the most important elements for you when you choose the cereal which you will buy?

*technique: hierarchy of the importance of attributes

\section{PERCEPTION OF THE PRODUCT}

$\Rightarrow$ How would you define/ describe the cereal(s) you have bought and eaten? Why? [Extend the comments of the respondents by asking: How? Can you explain better by giving an example?]

$\Rightarrow$ In your opinion, what are the characteristics of people who buy and eat this breakfast cereal? [Consider the 
name(s) mentioned by respondent in the previous question. Limit to 5-6 brands]

[Attempt to get comments out of the respondents, if not, mention social class, educational level, sports] exercise, working out of home, type of food they eat, whether they are on a diet, age, income, others]

7. OPINION OF THE PACKAGING

$\Rightarrow$ Thinking just of the packaging, what do you remember of the packing of these breakfast cereals? [Brands which were mentioned by respondent]

[Note separately the different elements which are thought of for each type of packaging such as type, design, format, appeals to nutritional value, use of expressions, brand, expiration date (validity), composition of the product/ ingredients, suggestions for preparation/ recipes, expressions like "no cholesterol", "source of", advice on portions, mamufacturer, pictures of people or other images. Go into greater depth on the comments of the respondent about these elements. Write the different elements for each type of packaging on the cards]

$\Rightarrow$ What role does packaging play in your decision to buy a breakfast cereal? In your opinion, of the following purposes/ objectives: protect cereal from breakage/ contamination, preserve freshness, source of information, supplying a consumer service, and others, what is the role of the packaging, when you acquire a breakfast cereal?

$\Rightarrow$ Which information did you most easily find? And which least easily?

[Consider the brand(s) that consumer mentioned to have bought and consumed; ask the consumer to relate the information for both situations and to comment on the experience - the ease and difficulty she found]

$\Rightarrow$ Does the nutritional information printed on the packaging provide you with adequate information about the cereal and when to eat it [breakfast, snack]?

[Try to obtain information such as typeface, letter size, portions, units of weight, etc.]

$\Rightarrow$ Can all the information about packaging that you have given me up to now be grouped according to the role that they play? How would you group these pieces of information?

[Observation: consider the role of the cereal packaging to be "protect cereal from breakage/ contamination", "preserve freshness", "source of information", "supplying a service to the consumer", "fulfilling legal requirements", "attractiveness", others. Note on a card the groups formed by the consumer from the information on the chosen packaging]

\section{THE IDEAL PACKAGING FOR BREAKFAST CEREALS}

$\Rightarrow$ For the cereal(s) you have bought and eaten, what other information do you believe should be put on the packaging in addition to the information that is already there?

[Attempt to discover all the elements which would help the consumer at the moment of purchase and consumption of the cereal]

$\Rightarrow$ For the cereal(s) you have bought and eaten, in what way would you present the information [including that mentioned by the respondent in the previous question] on breakfast cereal packaging?

[Ask the consumer to exemplify and comment on suggestions made on the placement of information]

\section{THE INFLUENCE OF THE CONSUMER AFFAIRS ON THE PACKAGING}

$\Rightarrow$ For breakfast cereals, what do you believe is the appropriate role for the Consumer Affairs Department? [Attempt to get information such as providing services and information, complementing information printed on the packaging, etc.]

$\Rightarrow$ Have you ever used the Consumer Affairs Department of the manufacturers of breakfast cereals [consider the cereal(s) consumer mentioned to have bought and consumed]? What kind of problem caused you to contact them?

[Ask the consumer to comment on the fact which led him or her to contact the Consumer Affairs Department]

$\Rightarrow$ What other type of information about the breakfast cereals could be provided by the Consumer Affairs Department of the manufacturers?

[Ask the consumer to mention the information and justify her reply]

Many thanks, you have been very helpful. 
Cidade:

País:

Data:

No Entrevista:

Entrevistador:

Pais:

\section{ROTEIRO DE ENTREVISTA - EMPRESA PRODUTORA DE CEREAIS MATINAIS}

\section{CARACTERIZAÇÃo DA EMPRESA}

\begin{tabular}{|ll|}
\hline Nome da Empresa: & Fone: \\
Endereço: & Cep: \\
\hline Ramo de Atividade da Empresa (Mix Produtos): & Fundada em: \\
Área de Atuação Geográfica: & No Estabelec.: \\
Faturamento da Empresa: & No Empregados: \\
\hline Nome do Entrevistado: & Depto.: \\
Experiência (Atuação) Profissional na Área: & \\
\hline
\end{tabular}

\section{ESTRUTURA DA EMPRESA}

$\Rightarrow$ Quais são as áreas funcionais envolvidas no processo de planejamento e desenvolvimento de embalagens de cereais matinais? Em cada área funcional, quais as atribuições específicas dos profissionais responsáveis? Entrevistador: pedir ao respondente que especifique as áreas funcionais internas e externas à empresa $e$ comente sobre a função desenvolvida pelos profissionais. Se for possível, entrevistar os profissionais principais influenciadores - envolvidos no processo.

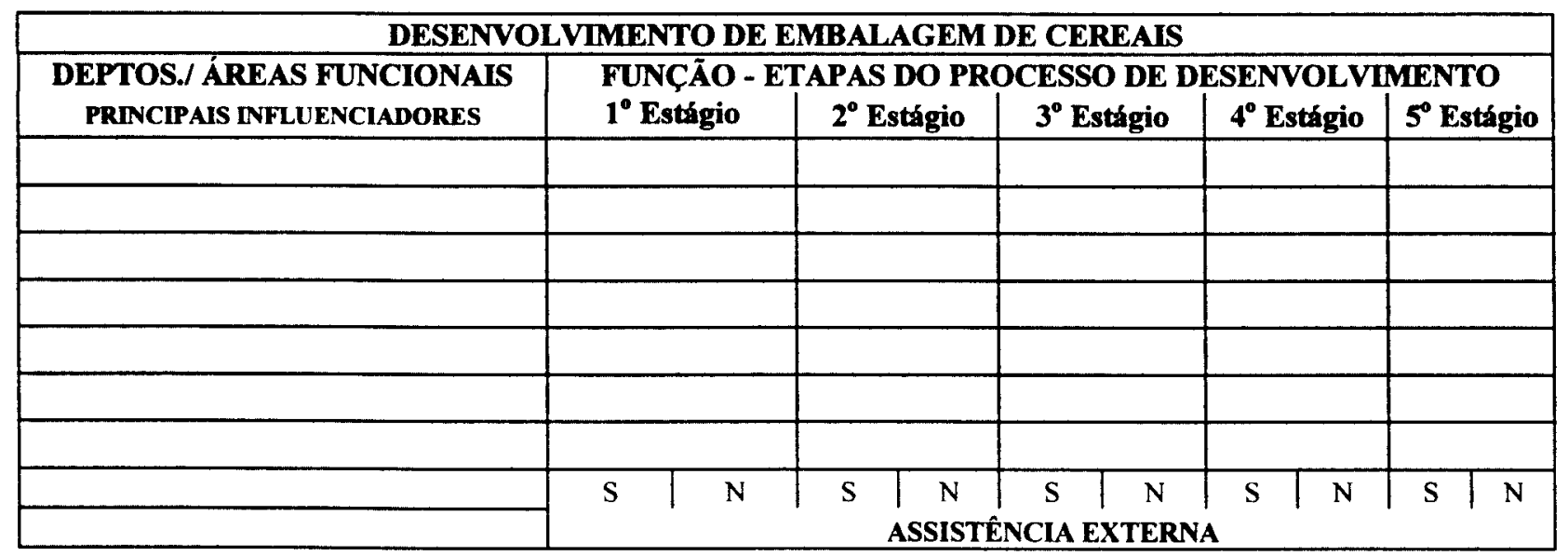

$\Rightarrow \mathrm{Na}$ sua empresa, quem é o principal coordenador do grupo de profissionais envolvidos no processo de planejamento e execução de ações relativas à elaboração da embalagem de cereais matinais? Entrevistador: aprofundar os comentários do respondente usando a expressão - Como assim?, você poderia explicar melhor, dando um exemplo?

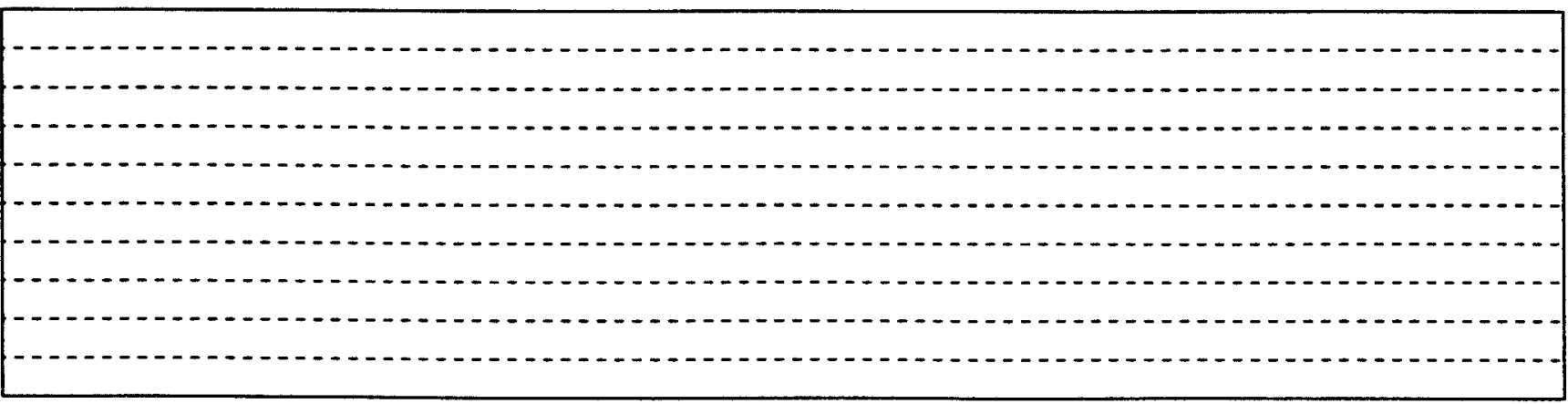




\section{CATEGORIAS DE CEREAIS MATINAIS}

\subsection{DESENVOLVIMENTO DA EMBALAGEM}

$\Rightarrow$ Quais os aspectos básicos que você considera no processo de desenvolvimento da embalagem de cereais matinais, na empresa onde trabalha?

\begin{tabular}{|l|l|}
\hline maquinaria: tamanbo & legislaçä; aparência \\
\hline distribuiciajo/ transportes & estocagem/armazenagem \\
\hline concorrentes: logística & comercializacão \\
\hline vendas: tamanho & outro(s)? qual(is)? \\
\hline
\end{tabular}

Entrevistador: verificar se o respondente tem "algo mais" a especificar. Procurar aprofundar cada aspecto básico comentado pelo entrevistado, usando a expressão: Como assim?, vocè poderia explicar melhor, dando um exemplo?

\begin{tabular}{|c|}
\hline \multicolumn{1}{|c|}{ CATEGORIAS DE CEREAIS } \\
\hline \\
\hline \\
\hline
\end{tabular}

\subsection{ASPECTOS CONCEITUAIS}

$\Rightarrow$ Na sua opinião, na empresa onde trabalha, qual é o papel estratégico do cereal matinal? Como você o definiria? Por quê diz isso?

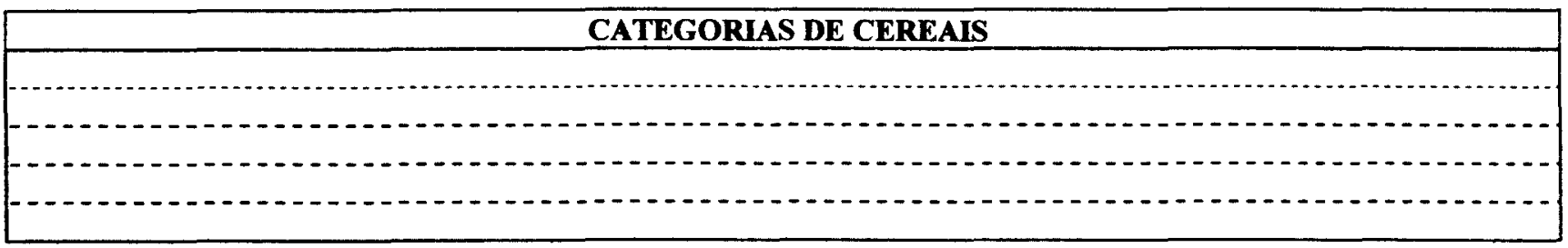

Entrevistador: aprofundar os comentários do respondente usando a expressão - Como assim?, você poderia explicar melhor, dando um exemplo?

$\Rightarrow$ Na sua opinião, na empresa onde trabalha, qual(is) $o(s)$ papel(is) desempenhado(s) pela embalagem de cereais matinais?

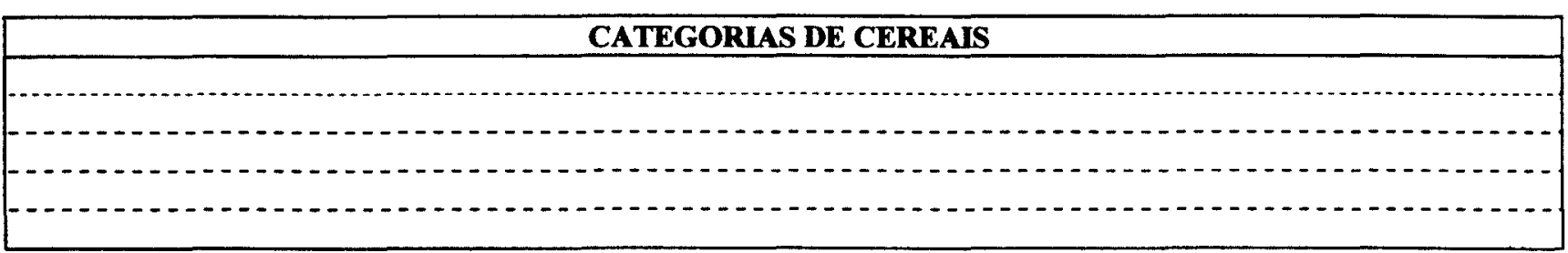

Entrevistador: se o respondente não mencionar como "papel" da embalagem de cereais - "proteção", "conservação", "fonte de informação", "fornecer um serviço ao consumidor", indagar quanto a essas expressões.

$\Rightarrow$ Tendo em vista o(s) papel(is) desempenhado(s) pela embalagem de cereais matinais, que aspectos são considerados pela empresa (segundo a ótica do produtor) no momento de definir o conjunto informativo/ elementos visuais empregado na embalagem desse produto?

Entrevistador: considerar "conjumto informativo" os elementos - escrita desenho, formato, marca, prazo de validade, chamadas sobre o valor nutricional, composição do produto/ ingredientes, sugestōes de preparo/ receitas, fabricante, simbolos, objetos/ figuras, cores, expressões como "sem colesterol", "fonte de", indicação de porções de consumo.

\section{CATEGORIAS DE CEREAIS}


Town:

Country:

Date:

No. Interview:

Interviewer:

INTERVIEW SCRIPT - MANUFACTURER OF BREAKFAST CEREALS

\section{CHARACTERISTICS OF THE COMPANY}

\begin{tabular}{|ll|}
\hline Name of the Company: & Phone: \\
Address: & Zip: \\
\hline Sector (Mix Products): & When founded: \\
Geographical area: & No. of factories: \\
Annual turnover: & No. of employees: \\
\hline Name of interviewee: & Dept.: \\
Professional experience in the area: & \\
\hline
\end{tabular}

\section{STRUCTURE OF THE COMPANY}

$\Rightarrow$ What functional areas participate in the planning and development of breakfast cereal packaging? In each of the functional areas (production or operation/factory, etc.), what are the specific attributes of the professionals in charge?

Interviewer: ask the respondent to specify the internal and external functional areas and comment on the work of the specialists. If possible, interview the specialists involved in the process.

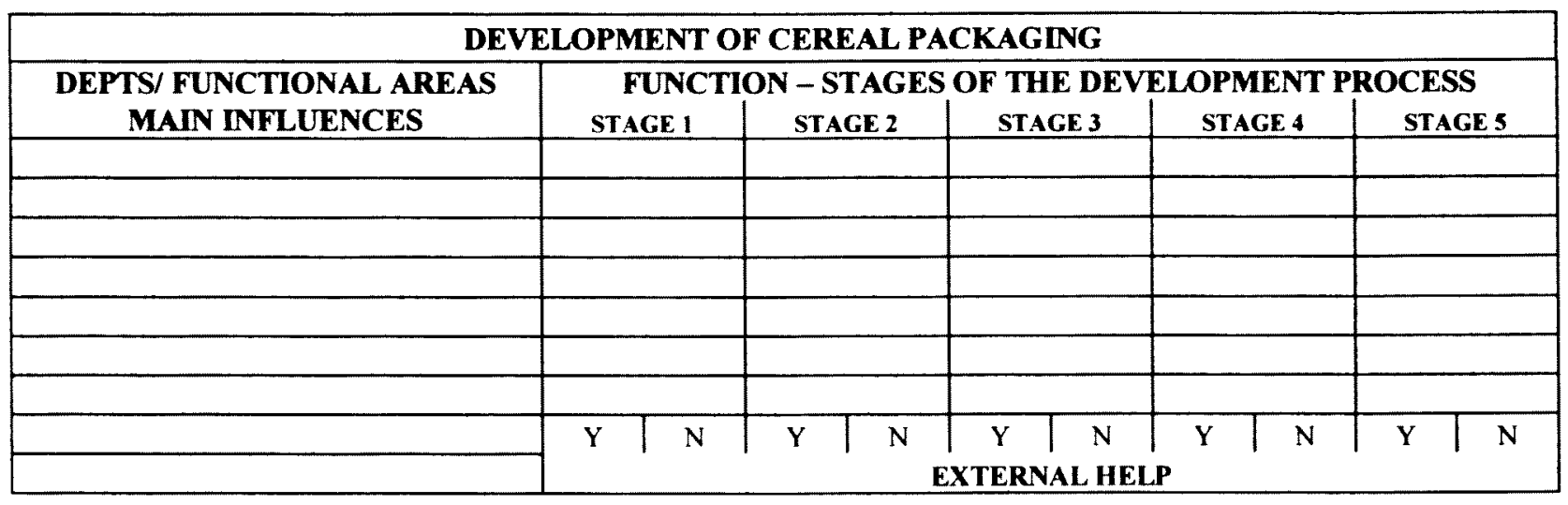

$\Rightarrow$ In your company, who is the main person involved in the planning and the design of breakfast cereal packaging?

Interviewer: extend the comments of the respondent using the expression: How? Can you explain more, giving an example?

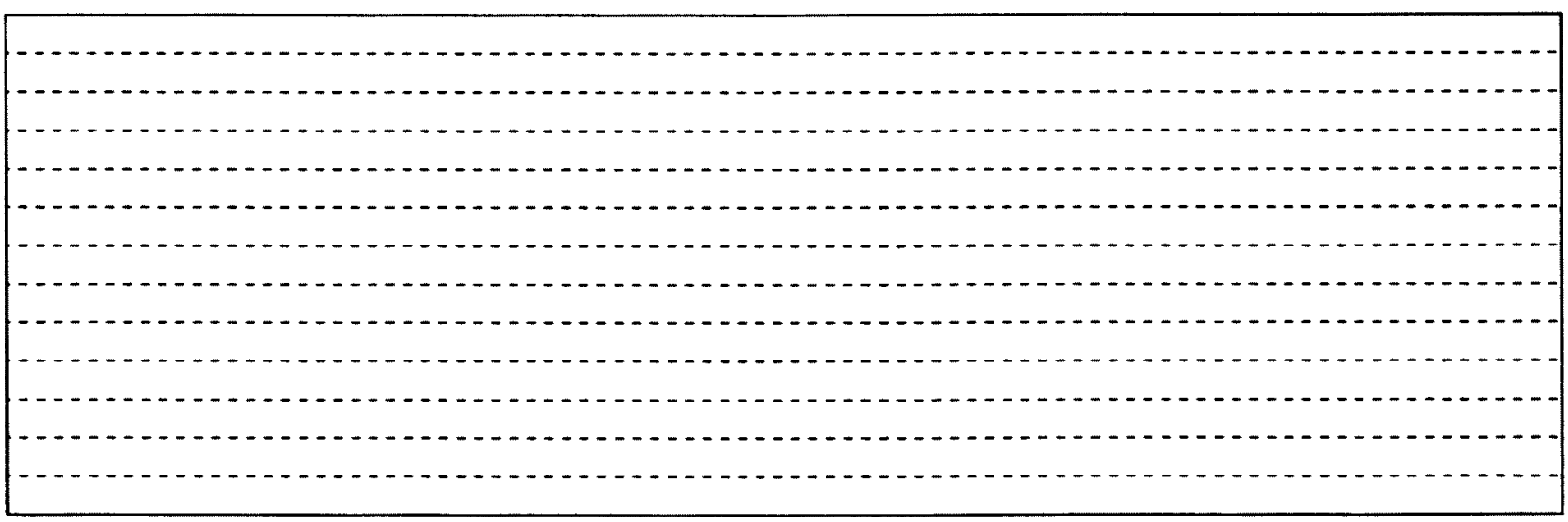




\section{CATEGORIES OF BREAKFAST CEREALS}

\subsection{DEVELOPMENT OF THE PACKAGING}

$\Rightarrow$ What are basic elements of the development process of breakfast cereal packaging in your company?

\begin{tabular}{|l|l|}
\hline machinery; appearance & legisiation: sales; size \\
\hline distribution/ transport & stocking/ storing \\
\hline competitor; logistics & others? which? \\
\hline
\end{tabular}

Interviewer: check whether the respondent has anything else to say. Attempt to: extend the comments of the respondent using the expression: How? Can you explain more, giving an example?

\begin{tabular}{|r|r|}
\hline \multicolumn{1}{|c|}{ CATEGORIES OF CEREALS } \\
\hline \\
\hline \\
\hline
\end{tabular}

3.2. CONCEPTUAL ASPECTS

$\Rightarrow$ What is the strategic role of breakfast cereal in your company? How would you define it? Why?

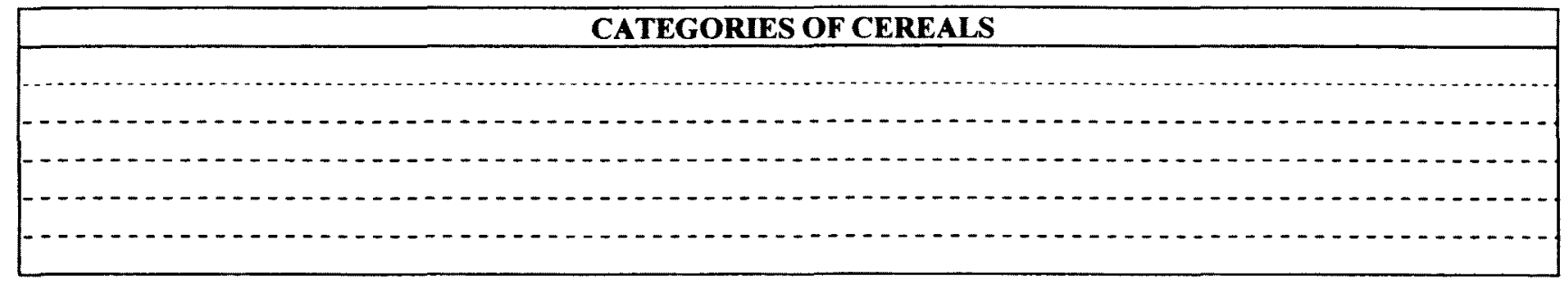

Interviewer: extend the comments of the respondent using the expression: How? Can you explain more, giving an example.

$\Rightarrow$ In your opinion, what is/ are the role(s) of the breakfast cereal packaging in your company?

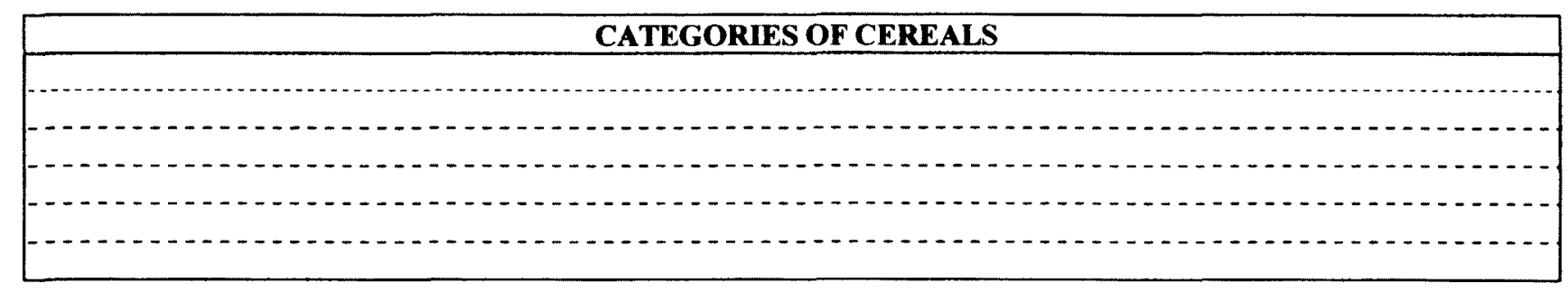

Interviewer: if the respondent fails to mention "ideas", food, dietary complement, healthy, practical, ask him or her about these expressions.

$\Rightarrow$ Bearing in mind the role(s) of the cereal packaging, what aspects are considered by the company (from the producer's point of view) when the set of informative and visual elements on the packaging of the product is decided?

Interviewer: consider "set of information" to be the size and shape of the type, the brand, expiration date, the nutritional value, the composition of the product/ ingredients, suggestions for preparation/ recipes, manufacturer, symbols' figures, colors, etc.

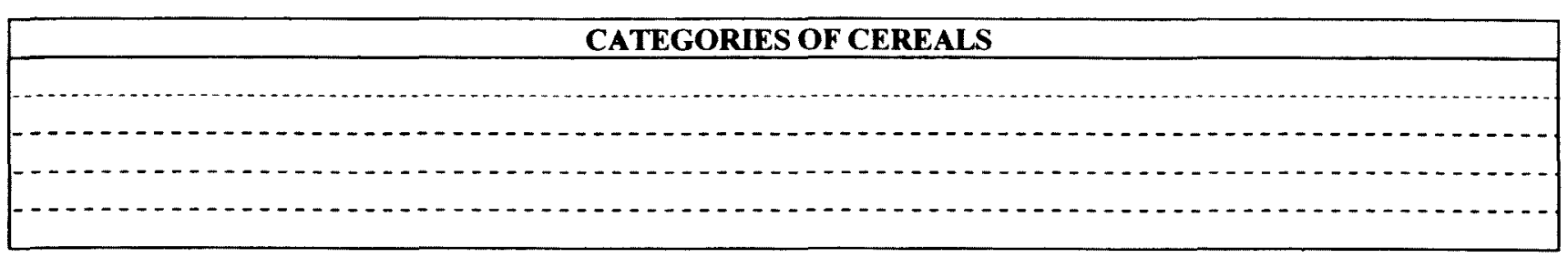


$\Rightarrow \mathrm{Na}$ sua opinião, que idéias o conjunto informativo/ elementos visuais inserido na embalagem de cereais matinais, da empresa onde trabalha, transmite ao consumidor?

Entrevistador: considerar "conjunto informativo" os elementos - escrita desenho, formato, marca, prazo de validade, chamadas sobre o valor nutricional, composição do produto/ ingredientes, sugestões de preparo/ receitas, fabricante, simbolos, objetos/ figuras, cores, expressões como "sem colesterol", "fonte de", indicação de porções de consumo. Se o respondente não mencionar como "idéias" - alimento, complemento alimentar, bom para a scride, prático no preparo, indagar quanto a essas expressões.

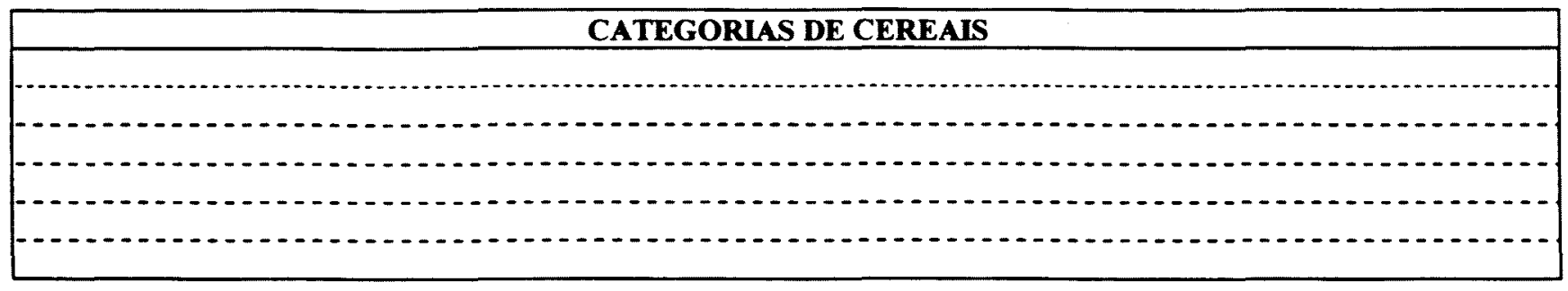

$\Rightarrow$ As informaçðes inseridas na embalagem de cereais matinais podem ser agrupadas, dependendo da sua finalidade? Como seria a composição desses grupos, com seus correspondentes elementos?

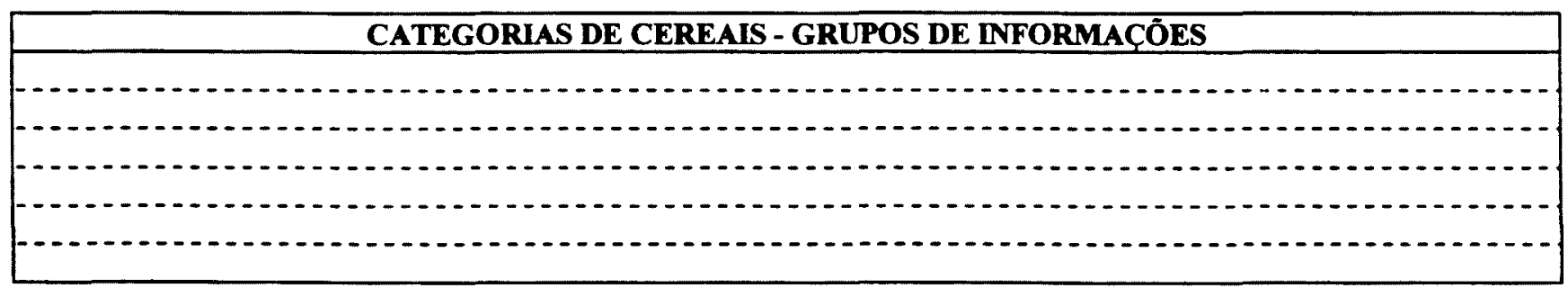

Entrevistador: considerar como "finalidade" da informação: "proteção", "conservação", "fonte de informaçāo", "fornecer um serviço ao consumidor", "preenchimento de exigências legais", "atratividade", outros. Anotar em um cartão os grupos formados pelo consumidor, a partir das informações existentes na embalagem escolhida.

\subsection{RELEVÂNCLA DOS ATRIBUTOS}

$\Rightarrow$ Neste momento, vamos considerar o conjunto de informaçōes presente na embalagem de cereais matinais. $\mathrm{Na}$ sua opinião, qual a ordem de importância [relevância] atribuida pela empresa a cada um dos elementos constituintes das embalagens desse produto?

Entrevistador: anotar o nivel de releväncia (em ordem decrescente de importância) atribuido aos elementos. Pedir ao respondente que comente sobre os três primeiros niveis de relevância.

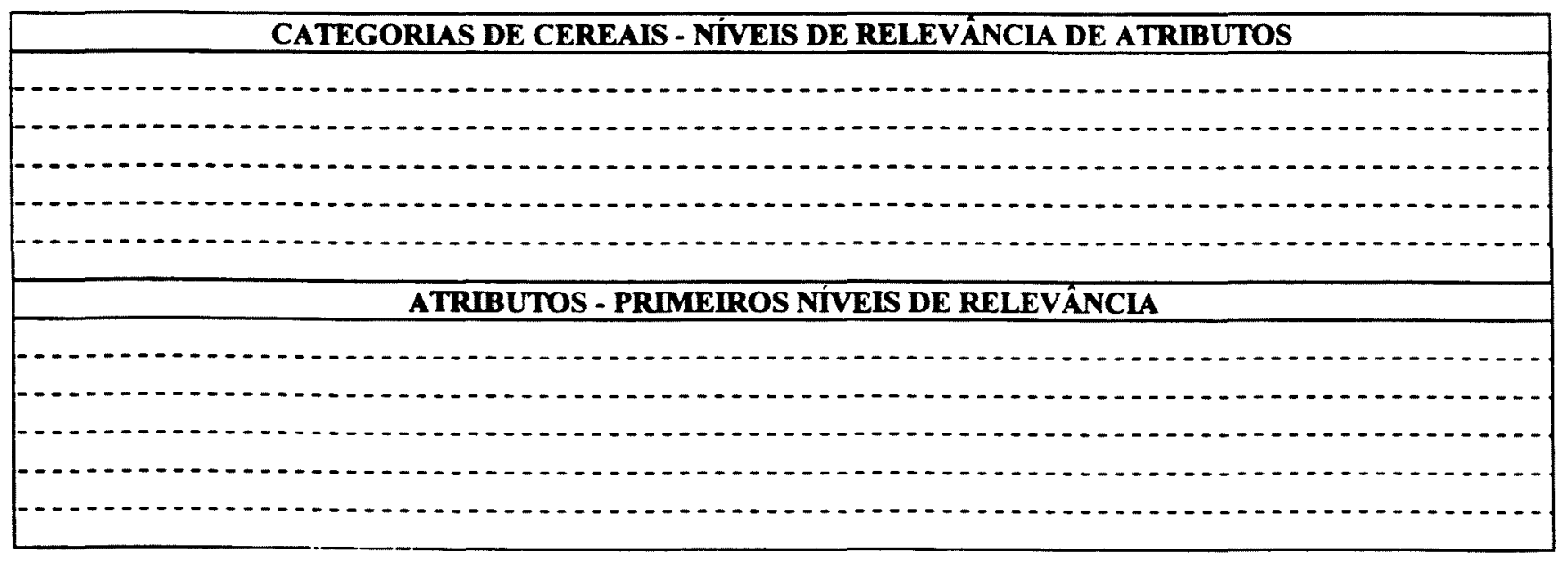




\subsection{COMUNICAÇĀO DA EMBALAGEM}

$\Rightarrow$ No planejamento e desenvolvimento do binômio produto/ embalagem de cereal matinal, que caracteristicas sócio-econômicas e demográficas, estilo de vida e hábitos do público alvo desse item alimenticio são levados em consideração pela empresa?

\begin{tabular}{|r|r|}
\hline \multicolumn{1}{|c|}{ CATEGORIAS DE CEREAIS $-\mathrm{PRODUTO}$} \\
\hline $\mathrm{E}$ \\
\hline $\mathrm{EMBALAGEM}$ \\
\hline
\end{tabular}

Entrevistador: se o respondente não mencionar - grau de instrução, pratica esporte, trabalha fora de casa. cargo que exerce no serviço, tipo de alimento que consome, segue uma dieta alimentar, idade, renda, região geográfica, indagar quanto a essas características.

$\Rightarrow$ Considerando a embalagem como um elemento de comunicação com o consumidor, quais os principais aspectos que influenciam a escolha dos elementos visuais que ela irá conter?

Entrevistador: caso o respondente não considere os "elementos visuais" segundo os aspectos legais, em termos técnicos, de acordo com exigéncias do mercado consumidor, indagar quanto a esses aspectos.

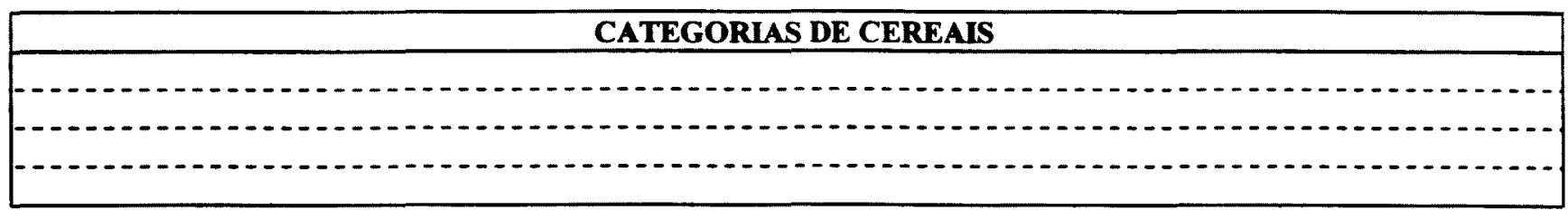

\section{CRTTÉRIOS DE ESCOLHA DE CEREAL MATINAL}

$\Rightarrow$ Na sua opinião, na empresa onde trabalha, de que maneira o consumidor escolhe os cereais matinais? Comente sobre os critérios que levam o consumidor a fazer a sua escolha.

Entrevistador: procurar identificar conjunto de informações como: formal formato da embalagem, cores. objetos/ figuras, simbolos, marca, prazo de validade, tamanho da letra, composição do produto/ ingrediemes, valor nutricional, receita, serviço de atendimento ao consumidor, expressões - "sem colesterol", "fonte de", outros. Aprofundar comentários do respondente.

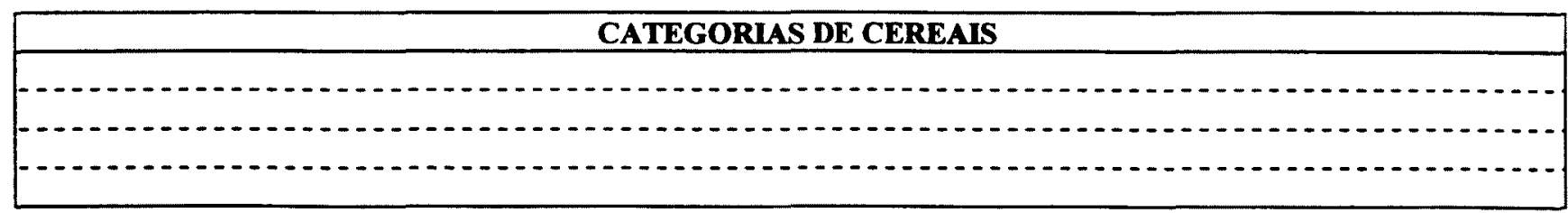

\section{HÁBTTO DE COMPRA E CONSUMO DO CONSUMIDOR}

$\Rightarrow$ Na sua opinião, na empresa onde trabalha, o que leva o consumidor a consumir cereais matinais?

Entrevistador: procurar identificar caracteristicas que relacionem o consumo do produto como "ume alimentação saudável e prática", tais como: valor nutricional, alimento rico em fibras e vitaminas, facilidade no preparo, pronto para o consumo, porções de consumo.

\begin{tabular}{|c|}
\hline \multirow[t]{2}{*}{ CATEGORIAS DE CEREAIS - CRITÉRIOS, SEGUNDO A ÓTICA DO PRODUTOR } \\
\hline \\
\hline 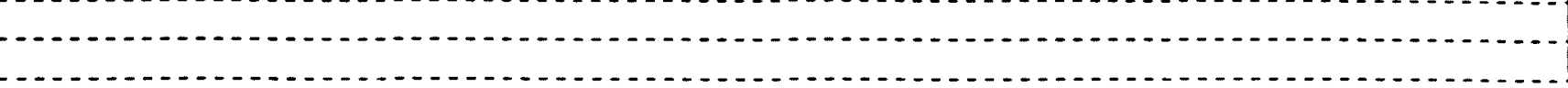 \\
\hline
\end{tabular}


$\Rightarrow$ In your opinion, how do the informative content and visual elements of the packaging communicate to the consumer in your company?

Interviewer: consider "set of information" the elements - typeface, design, format, brand, expiration date appeals to mutritional value, composition of the product/ ingredients, preparation suggestions/ recipe, manufacture, symbols, objects/figures, colors, expressions such as "no cholesterol", "source of", advice on portions. If the respondent fails to mention as "ideas" - it's more nourishing, food complement, healthy, practical to prepare. Inquire about these expressions.

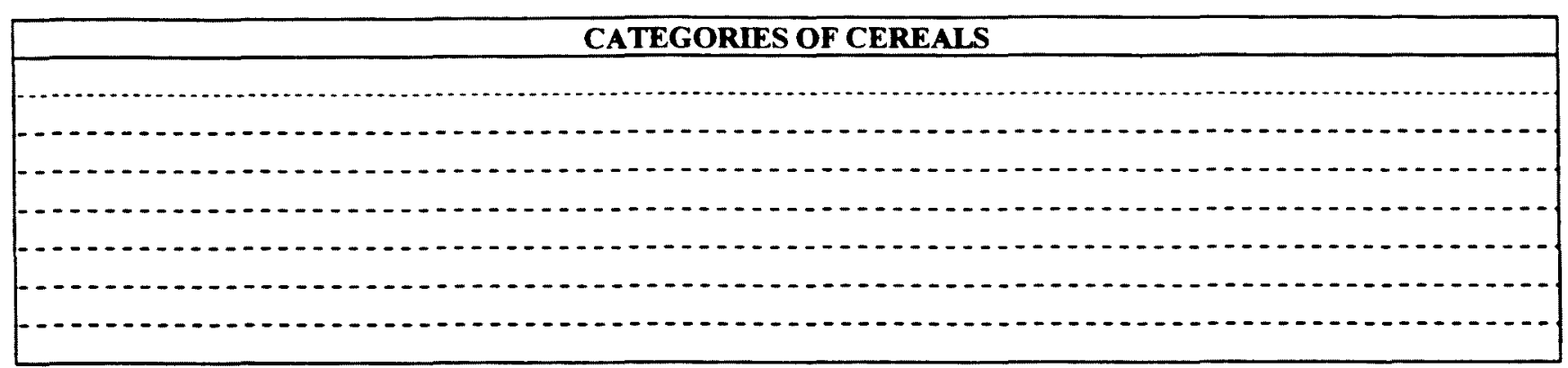

$\Rightarrow$ Can the information on the breakfast cereal packaging be categorized [grouped] according to its objectives/ aims? If so, what would these categories [groups] be? What would the characteristics of each category [group] be?

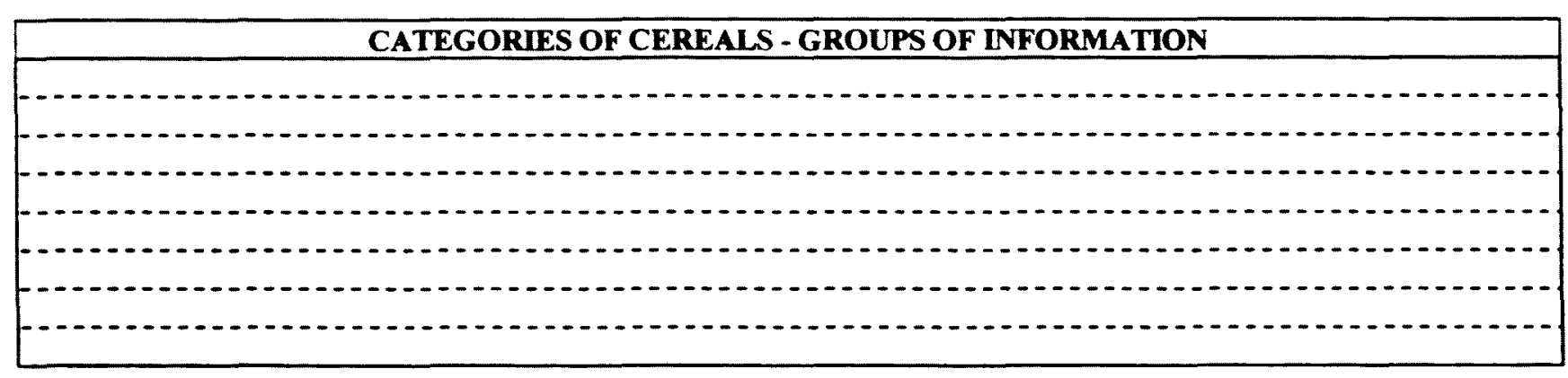

\subsection{RELEVANCE OF THE ATTRIBUTES}

$\Rightarrow$ Let us consider the set of information on the breakfast cereal packaging. In your opinion, how does the company rank the importance of the elements that make up the packaging of the product? Interviewer: note the ranking (in decreasing order) of the elements. Ask the respondent to comment on the first three positions.

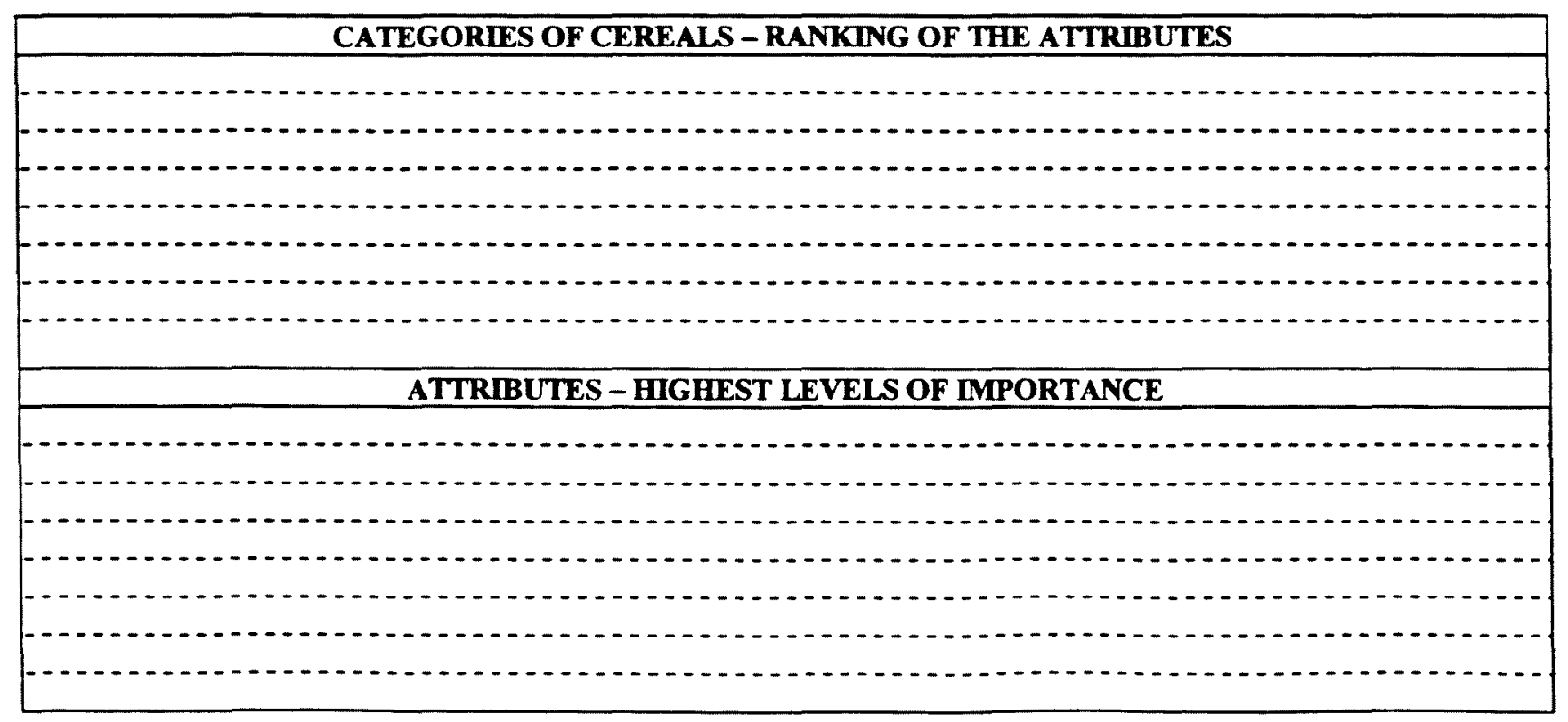


$\Rightarrow$ For the target market, what socio-economic and demographic characteristics, lifestyles and habits does the company consider in the planning and development of the cereal and its packaging?

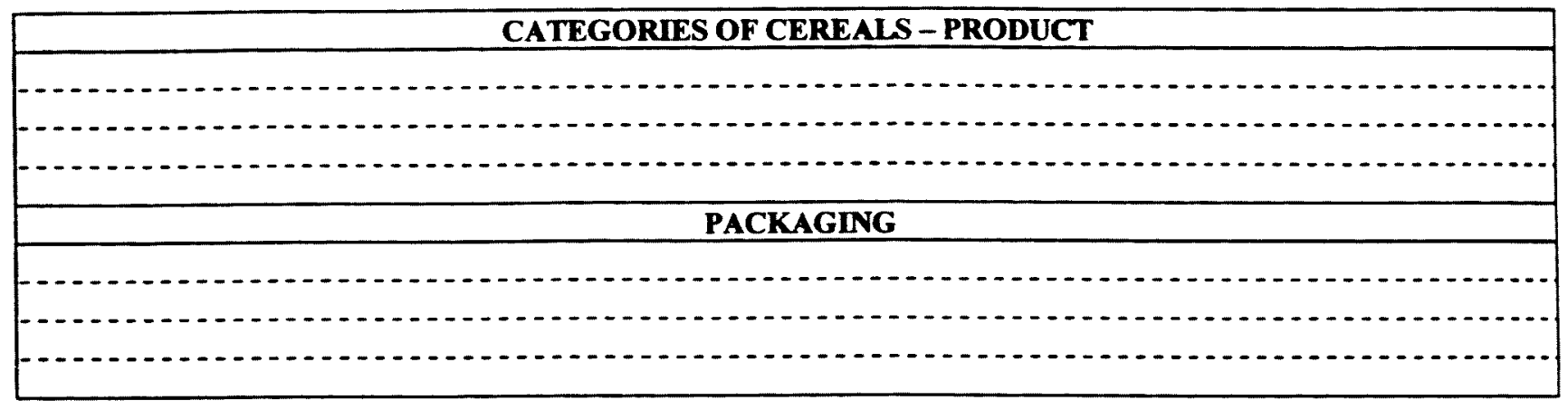

Intenviewer: if the respondent fails to mention level of ectucation, sports, working out of the house, job, type of food consumed, following a diet, age, income, geographical region, ask about these characteristics.

$\Rightarrow$ Considering the packaging as a means of communication with the consumer, what are the main eler that influence the choice of the visual elements which it will contain?

Interviewer: if the respondent fails to mention "visual elements", legal aspects, "according to the demands of the consumer market", ask him or her about them.

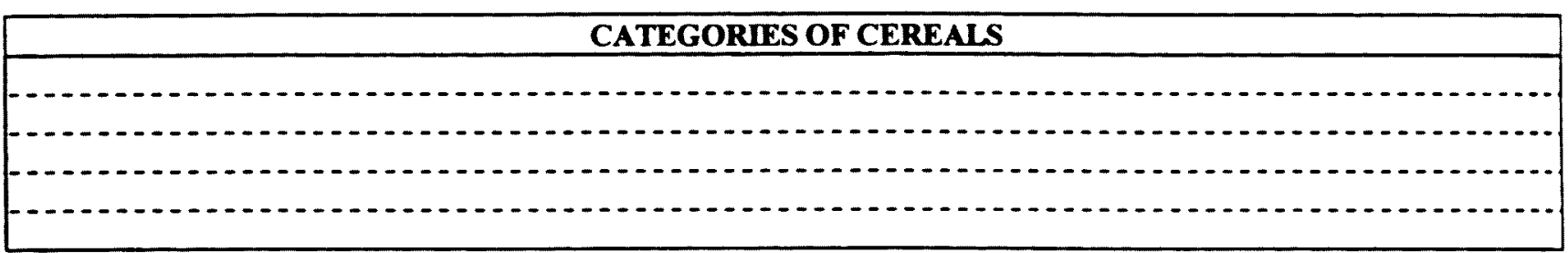

\section{CRITERIA FOR CHOOSING A BREAKFAST CEREAL}

$\Rightarrow$ In your opinion, how does the consumer choose the breakfast cereals of your company? Comment on the criteria which lead the consumer to make his/ her choosing.

Interviewer: Attempt to identify set of information: the formal format of the packaging, color, objects/ figures, symbols, brand, expiration date, letter size, composition of the product/ ingredients, nutritional value, recipe, consumer service, expressions - "no cholesterol", "source of". Go deeper into the comments of the respondent.

\begin{tabular}{|l|l}
\hline \multicolumn{6}{|c|}{ CATEGORIES OF CEREALS } \\
\hline
\end{tabular}

\section{CONSUMER PURCHASE AND CONSUMPTION HABITS}

$\Rightarrow$ In your opinion, what leads the consumer to consume breakfast cereals of your company? Interviewer: Attempt to identify characteristics which relate to the consumption of the product as "a healthy and practical food": nutritional value, rich in fiber and vitamins, easy to prepare, ready to eat, consumption portions.

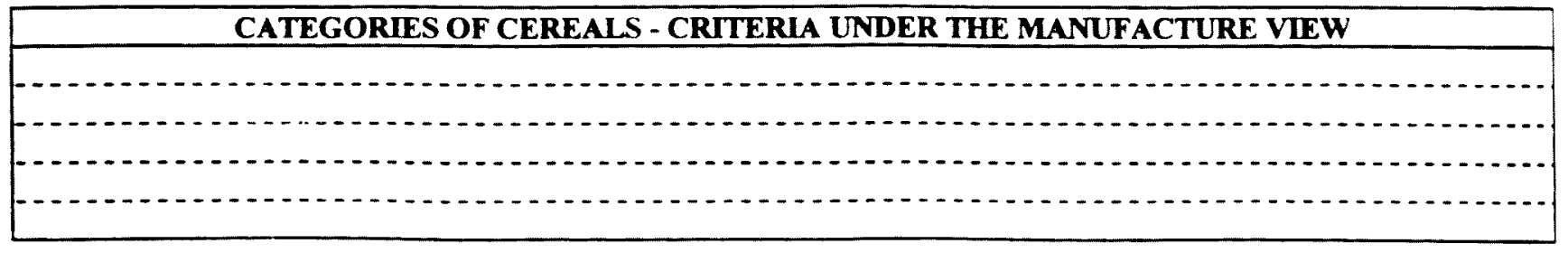




\section{A INFLUÊNCLA DO SAC NA EMBALAGEM}

Na sua opinião. na empresa onde trabalha, qual o papel do Serviço de Atendimento ao Consumidor - SAC? [Procurar levantar informaçōes como: prestar serviço, fornecer informação, complementar as informações impressas na embalagem. outros]

$\Rightarrow$ Que tipo de informação sobre os cereais matinais poderia ser complementada pelo SAC?

\section{CATEGORIAS DE CEREAIS}

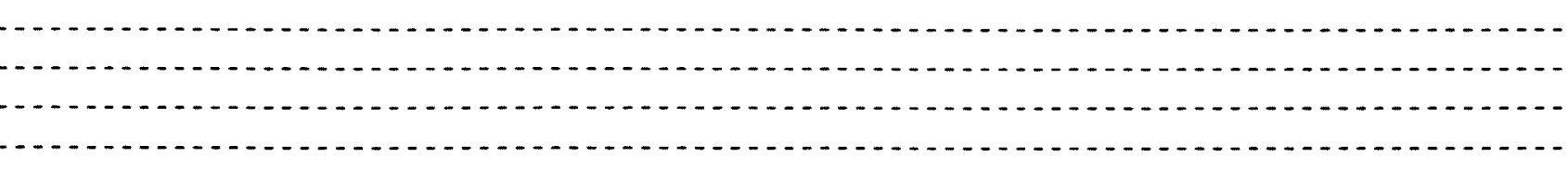

\section{EMBALAGEM IDEAL DE CEREAIS MATINAIS}

$\Rightarrow$ Com base em estudos que a empresa vem realizando para aprofundar o seu conhecimento sobre os padrões de compra e consumo dos usuários de cereais matinais, que elementos existentes, hoje, na embalagem desse produto, seriam modificados, a curto [1-2 anos] ou a médio prazo [5 anos no máximo], a partir das caracteristicas/ informaçees levantadas acerca desse público consumidor?

Entrevistador: aprofundar os comentários do respondente usando a expressão - Como assim?, vocè poderia explicar melhor, dando um exemplo?

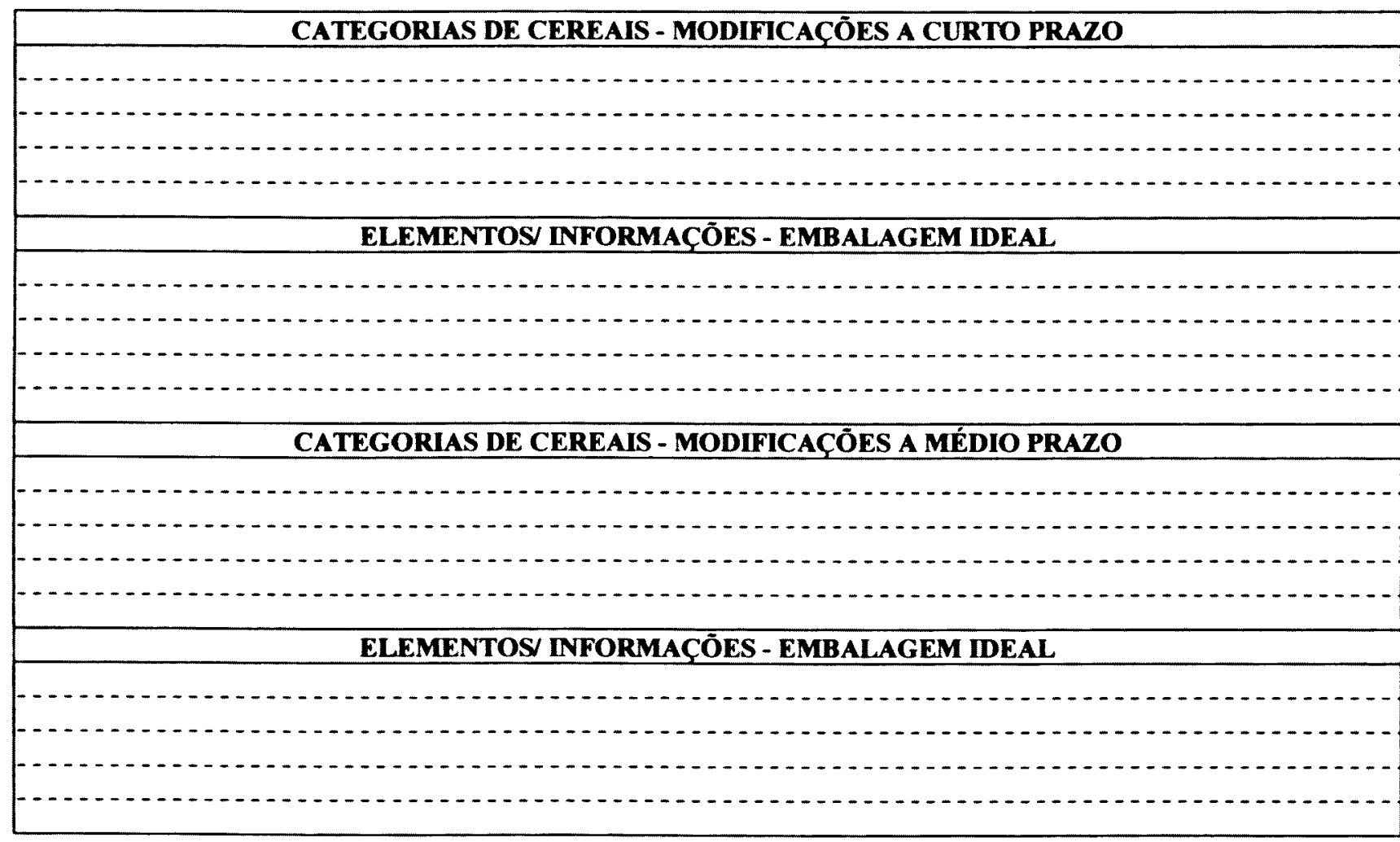


6. THE INFLUENCE OF THE CONSUMER AFFAIRS ON THE PACKAGING

$\Rightarrow$ In your opinion, what do you believe is the role of the Consumer Affairs Department of your company? Interviewer: Attempt to get information such as: providing services and information, complementing information printed on the packaging, etc.

$\Rightarrow$ What additional information about breakfast cereals can the Consumer Affairs Department provide?

\begin{tabular}{|l|l|}
\hline \multicolumn{6}{|c|}{ CATEGORIES OF CEREALS } \\
\hline
\end{tabular}

7. THE IDEAL BREAKFAST CEREAL PACKAGING

$\Rightarrow$ Based on the studies conducted by the company regarding consumption patterns of breakfast cereal consumers, what are the elements on the packaging that might be modified in the short [1-2 years] or medium [ 5 years in the maximum] term?

Interviewer: extend the comments of the respondent by using the expression - How? Could you explain better, giving an example?

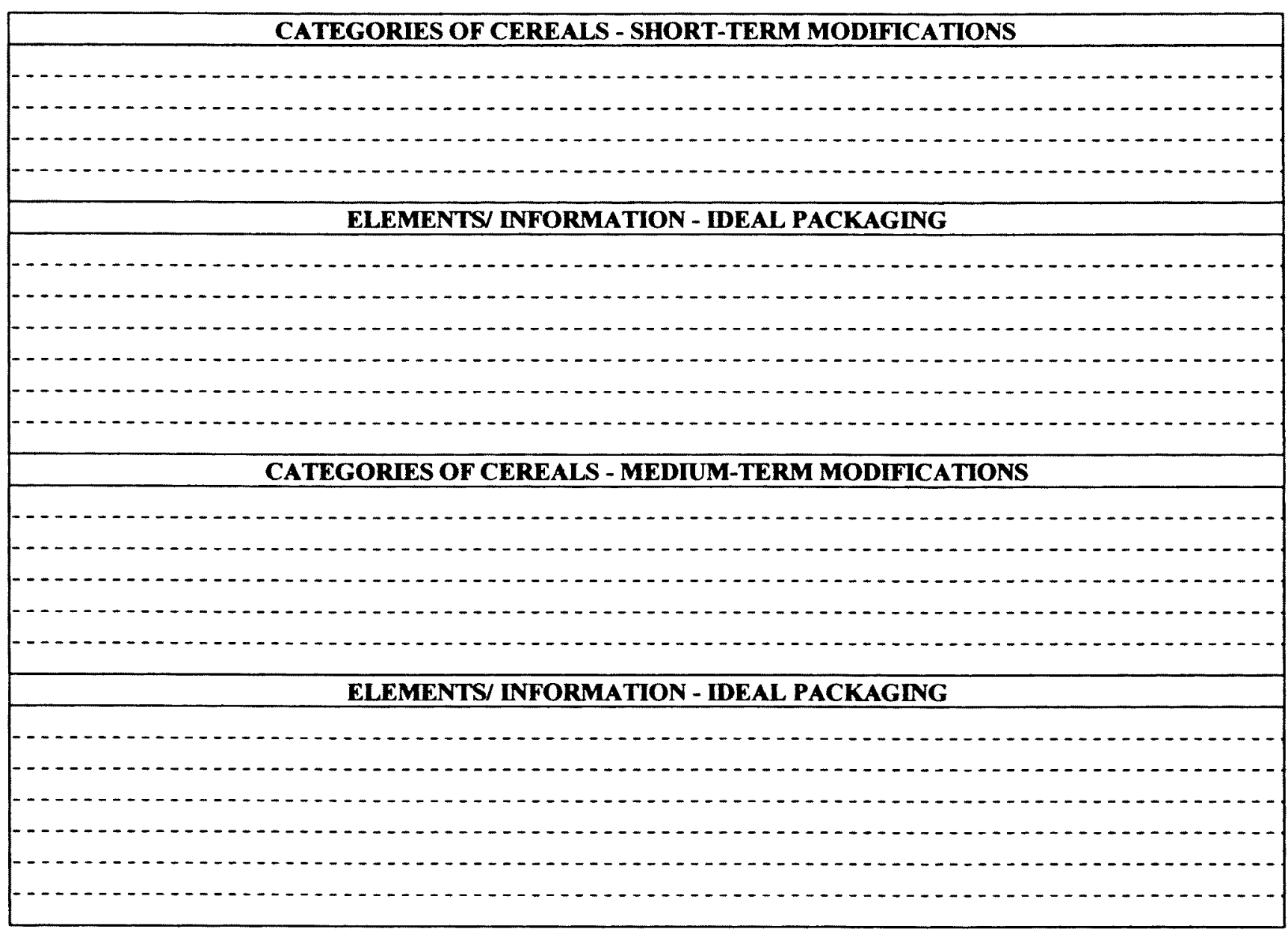




\section{APÊNDICE 4}

\section{CARTAS DE APRESENTAÇÃO}


$28^{\text {th }}$ December, 1998

Kellogg Company

Department of Marketing

Fred Jakyes - Vice President

Dear Mr. Jakyes:

Please allow me to introduce myself. My name is Virgínia Maria Ferraz de Castro, a doctoral student in the Department of Nutrition, Faculty of Public Health, University of São Paulo, Brazil. I am presently a visiting scholar in residence at Georgia State University, in the Department of Marketing. My dissertation research concerns a comparative study of the strategies used by American and Brazilian consumers in their selection, acquisition and use of food products. More specifically, the project examines selected aspects of cereal packaging.

In this vein, I am investigating package information attributes that American and Brazilian consumers consider, when they make boxed cereal purchases.

At the annual Partners of the Americas meeting that was held late November, in Washington, DC, I had opportunity of meeting Dr. Norman A. Brown, president emeritus of the W. K. Kellogg Foundation and the new president of Partners of the Americas. He encouraged me to contact your company and was confident you could help me.

On $2^{\text {nd }}$ February of 1999 , I will be visiting the Packaging School at Michigan State University and keeping in touch with some researchers in my area at MSU. At the same occasion, I would like to visit the Kellogg Company, in Michigan, talk with some professionals of your department, and, properly, to get some first-hand information about cereal packaging development.

Along with this letter, I have enclosed a copy of my resume. I hope it gives you some idea about my work and me.

Thank you in advance for your assistance and helping me in making some contacts at Kellogg Company. I would like to inform you I have some urgency to get your answer. As my deadline for planning my trip and activities is 01/15/99. I look forward to your response.

Sincerely,

$$
\text { Virginia Maria Ferraz de Castro }
$$


E-mail: vmcastro@dglnet.com.br

Tel: $3051-7638$ (res.)

Fax: $3051-7639$

São Paulo, 12 de julho de 1999

Kellogg Brasil e Cia.

Departamento de Marketing

Andres Carranza - Gerente

\section{Prezado Sr. Carranza:}

Por favor, permita-me fazer minha apresentação. Sou doutoranda do Programa de Pós Graduação da Faculdade de Saúde Pública-USP, no Departamento de Nutrição. Entre junho/98 a maio/99, atuei como "visiting scholar" na Georgia State University, em Atlanta, GA, U.S., no Departamento de Marketing. Venho desenvolvendo em meu projeto de Tese um estudo comparado sobre as estratégias adotadas pelos consumidores brasileiros e norte-americanos na seleção, aquisição e uso de produtos alimentícios.

O projeto está sob a orientação do Prof. Dr. Rubens da Costa Santos e aborda aspectos selecionados das embalagens de cereais matinais. Estou realizando uma pesquisa internacional comparada sobre a estrutura de preferência de atributos com consumidores brasileiros e norte-americanos, acerca do conteúdo informativo das embalagens de alimentos dessa categoria de bens de consumo. A pesquisa verifica proposições conceituais de forma controlada, por intermédio da utilização de bases científicas e metodológicas.

A realização da pesquisa proporcionará contribuições acadêmicas, ao fazer um estudo comparado sobre as estratégias adotadas pelos consumidores brasileiros e norteamericanos na seleção, aquisição e uso de produtos alimentícios. Proporcionará também contribuições ao setor executivo, ao possibilitar a identificação do perfil de consumo dos usuários de um dado produto.

Durante o periodo de minha permanência nos Estados Unidos, tive a oportunidade de visitar a Kellogg Company, em Michigan, U.S., quando conversei com a Sra. Jeanne Figo, diretora do "Packaging \& Printing Services Department". Contei com total colaboração e desprendimento dessa diretoria, que possibilitou o levantamento das informações consideradas essenciais nessa fase do estudo. 
Antes de viajar para os Estados Unidos, foram estabelecidos contatos com a Sra. Carla Kamensek, na época Diretora Geral, que designou o Sr. Ricardo Desie Fort (Gerente de Produto). O Sr. Ricardo fềz o acompanhamento do nosso entendimento e forneceu o apoio necessário durante todo o tempo em que prestou serviço nessa conceituada empresa produtora de gêneros alimentícios.

Tendo concluído com sucesso a parte norte-americana do projeto acadêmico, gostaria de poder contar com a colaboração e autorização de V.Sa., para que eu venha a conversar com algum(s) profissional(s) de seu departamento, no sentido de obter informações referentes ao desenvolvimento da embalagem de cereais.

O presente estudo possuí caráter acadêmico, bem como o enfoque a ser empregado durante a realização da(s) entrevista(s) conterá, exclusivamente, a mesma dimensão acadêmica. Cabe ressaltar que as informações obtidas, antes de serem incorporadas ao texto final do estudo, serão levadas ao conhecimento da empresa.

A obtenção de uma decisão favorável é de fundamental importância para que eu possa dar continuidade ao desenvolvimento da porção brasileira de meu projeto de estudo comparado.

$\mathrm{Na}$ expectativa de continuar merecendo a atenção que vem sendo dispensada por essa conceituada empresa, apresento desde já meus protestos de estima e consideração.

\section{Cordialmente,}




\section{APÊNDICE 5 \\ EMBALAGENS CONSIDERADAS NO ESTUDO}




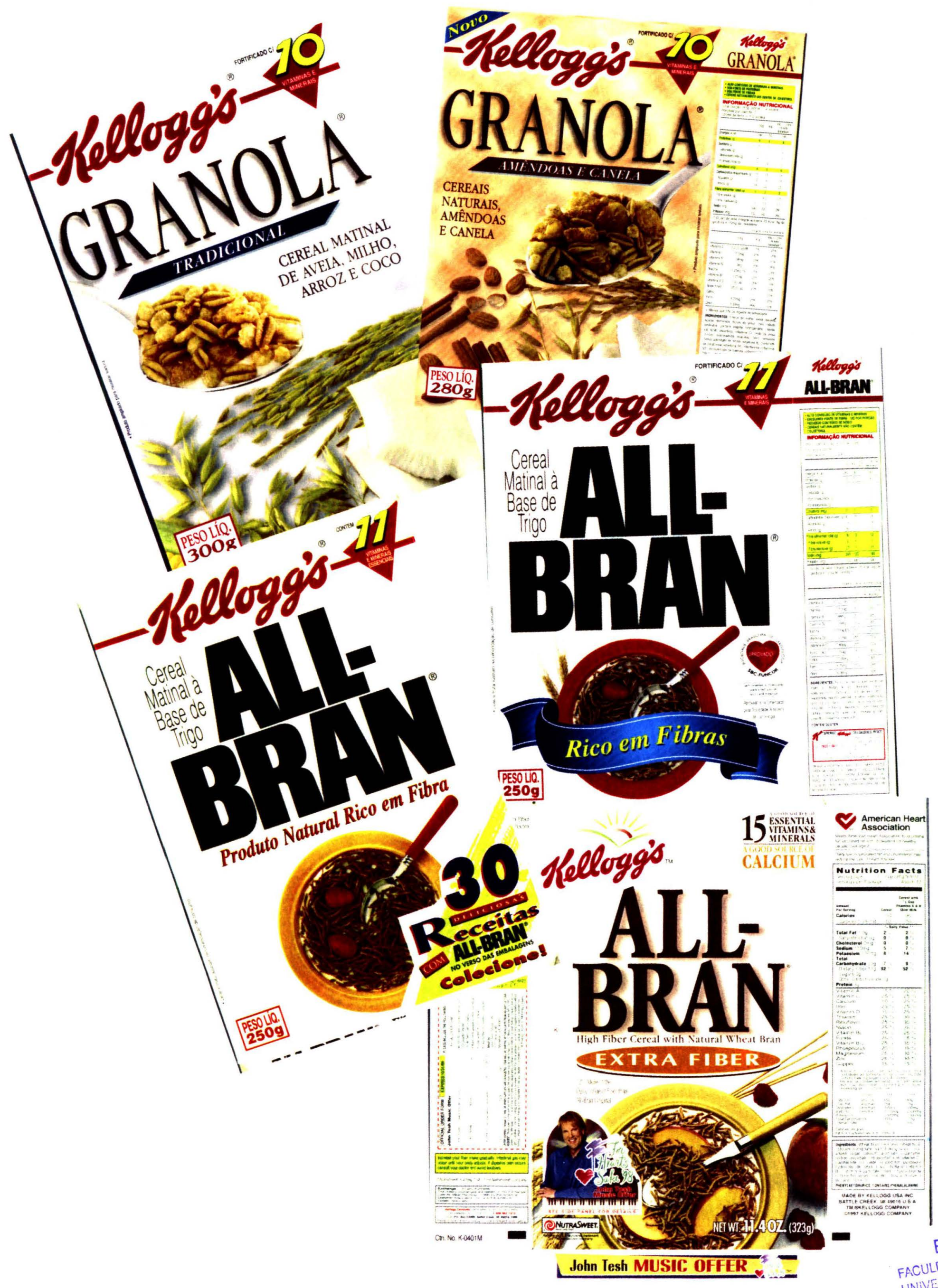

Biblioteca/CIR DESAUDEPÚBLLC DESAO PAUL 


\section{Newl}

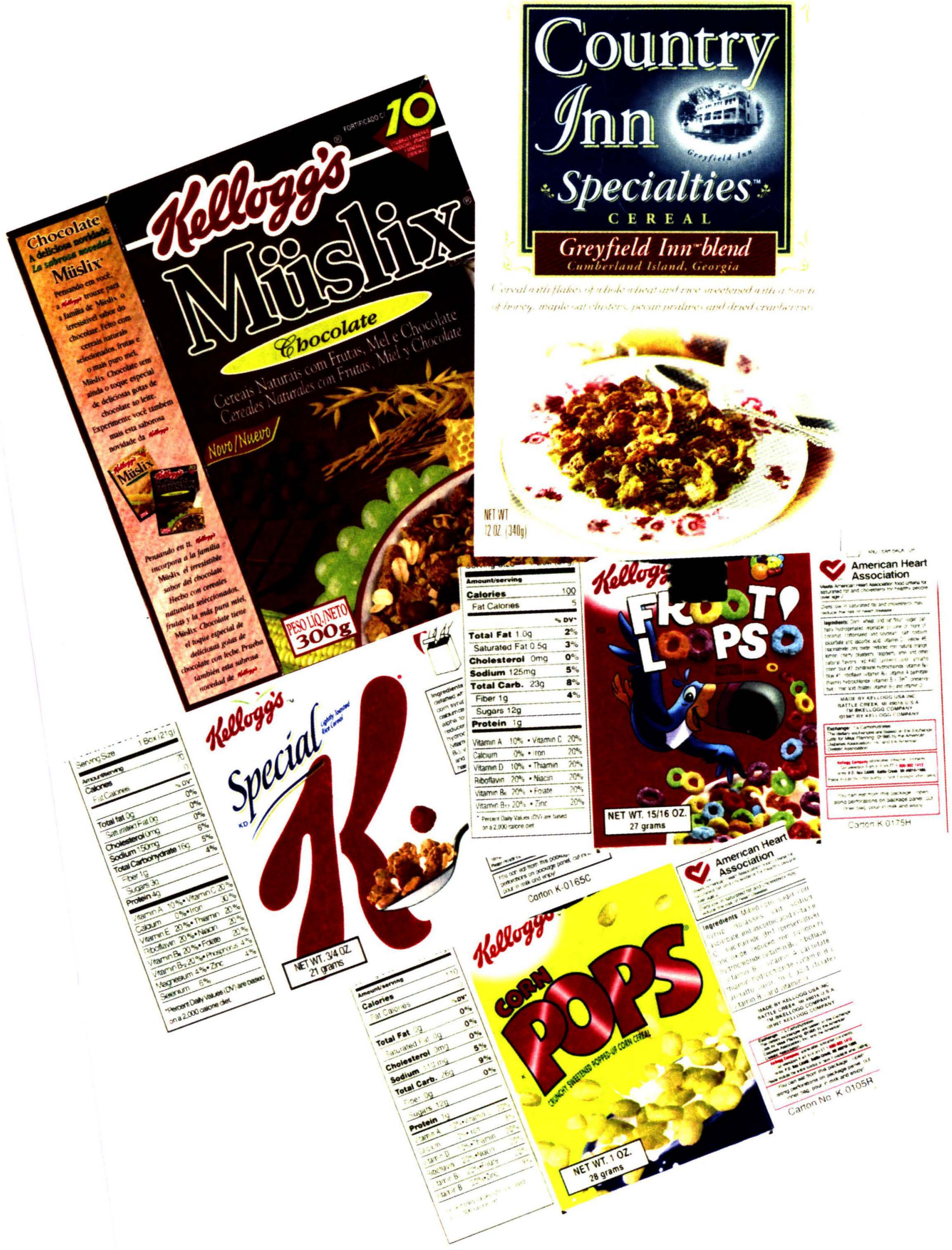




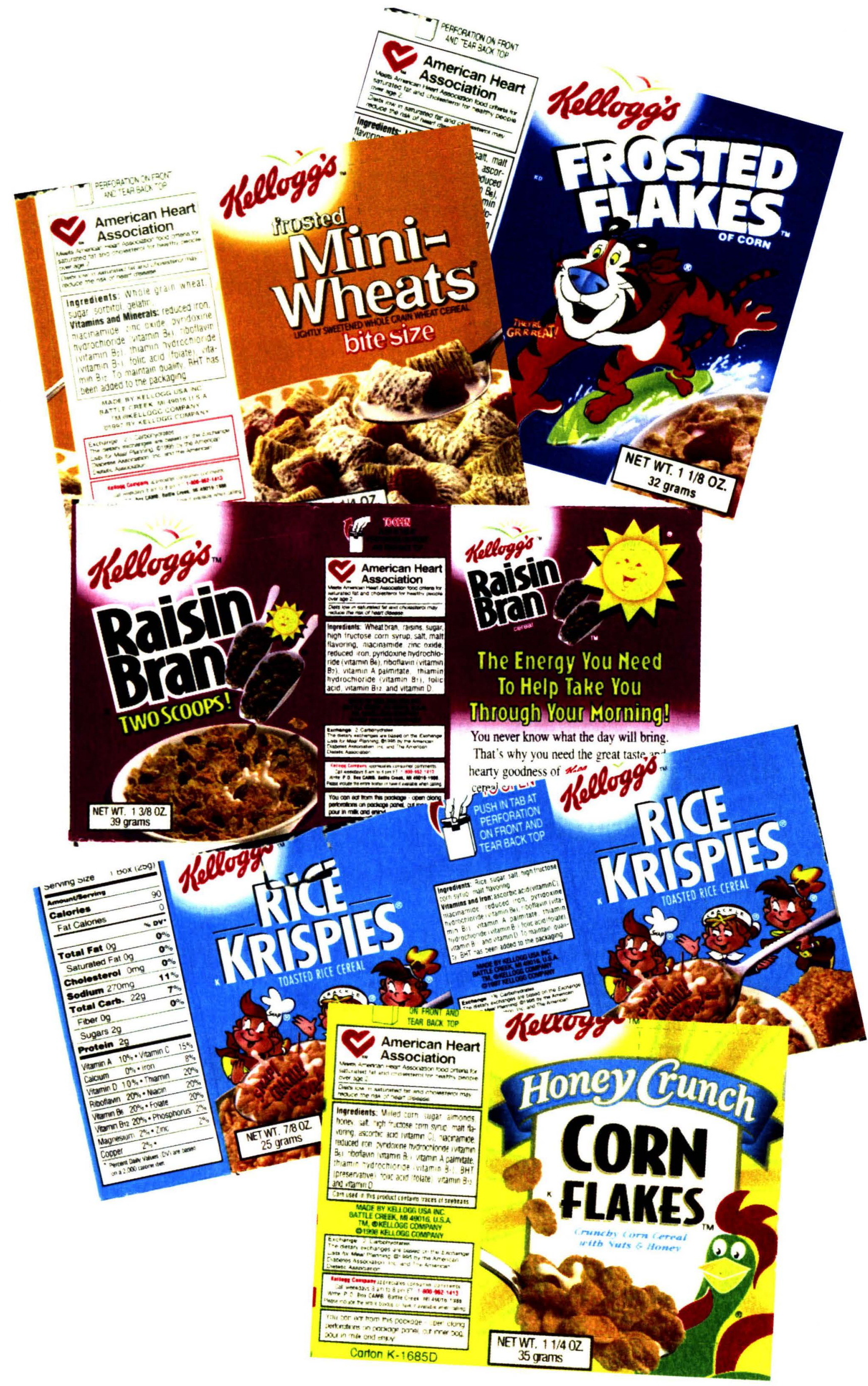




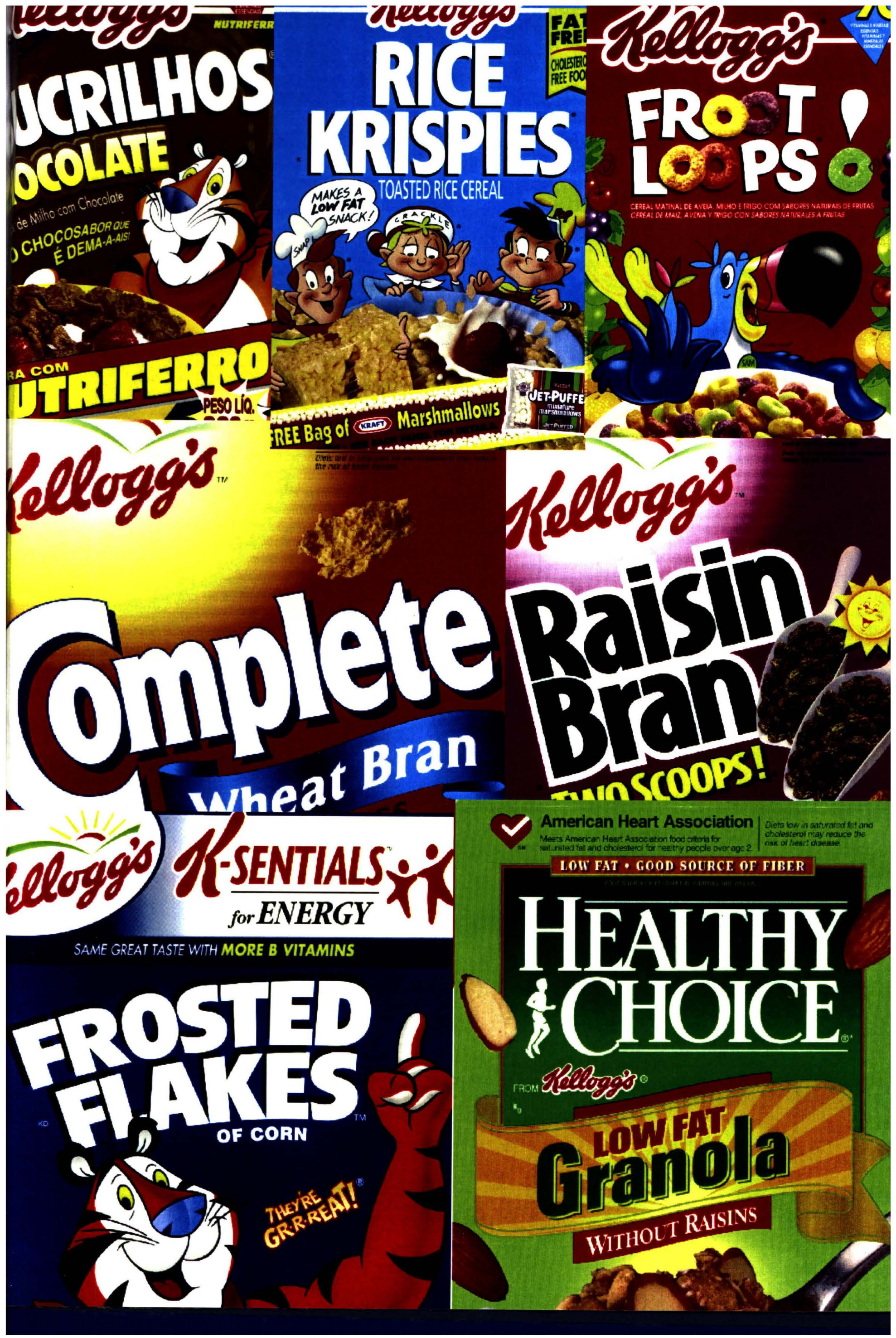

